\title{
BIOREMEDIATION DEMONSTRATION ON KWAJALEIN ISLAND: \\ SITE CHARACTERIZATION AND ON-SITE BIOTREATABILITY STUDIES
}

\author{
R.L. Siegrist 1 \\ N.E. Korte ${ }^{2}$ \\ D.A. Pickering 2 \\ T.J. Phelps ${ }^{3}$ \\ Environmental Sciences Division Publication No. 3733 \\ Date Published: September 1991 \\ Prepared for \\ Hazardous Waste Remedial Actions Programs (HAZWRAP) \\ Oak Ridge, Tennessee 37831 \\ Prepared by \\ OAK RIDGE NATIONAL LABORATORY \\ Oak Ridge, Tennessee 37831-6038 \\ Managed by \\ MARTIN MARIETTA ENERGY SYSTEMS, INC. \\ for the \\ U.S. DEPARTMENT OF ENERGY \\ under contract DE-AC05-84OR21400
}

1 Oak Ridge National Laboratory, Oak Ridge, Tennessee 37831-6038

2 Oak Ridge National Laboratory, Grand Junction, Colorado 81502-2567

${ }^{3}$ University of Tennessee, Knoxville, TN 37932-2567 


\section{CONTENTS}

Page No.

List of Figures............................................................................. v

List of Tables.................................................................................. vii

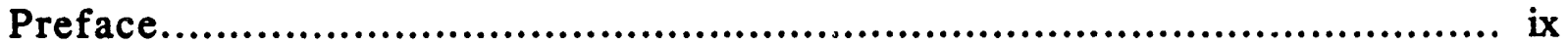

Acknowledgments............................................................................ xi

1. EXECUTIVE SUMMARY ........................................................... 1

2. INTRODUCTION.......................................................................... 3

2.1 Background........................................................................... 3

2.2 Synopsis of Site Conditions...................................................... 4

2.3 Objectives and Scope............................................................. 4

2.4 Report Organization.......................................................... 5

3. MATERIALS AND METHODS........................................................ 9

3.1 Introduction........................................................................ 9

3.2 Site Physical Characteristics............................................................ 9

3.2.1 Physical Setting............................................................... 9

3.2.2 Soil and Geology........................................................ 9

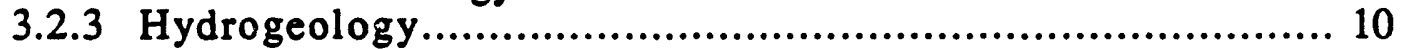

3.3 Site Contamination Characteristics............................................... 11

3.3.1 Diesel Fuel Characteristics................................................. 11

3.3.2 Soil Contamination.............................................................. 12

3.3.3 Groundwater Contamination.................................................. 13

3.4 On-site Biotreatability Studies...................................................... 13

3.4.1 Microbiology and Microcosm Experiments.................................... 13

3.4.2 Soil Respiration Experiments............................................... 14

3.5 General Work Conduct...................................................... 15

3.5.1 Decontamination and Waste Management................................... 15

3.5.2 Field Data Management and Recording....................................... 15

3.5.3 Health and Safety.......................................................... 15

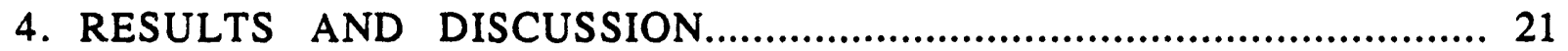

4.1 Site Physical Characteristics...................................................................... 21

4.1.1 Landscape and ropography............................................... 21

4.1.2 Generalized Subsurface Conditions........................................ 21

4.1.3 Soil and Geology................................................... 22

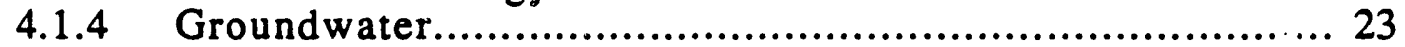

4.2 Site Contamination Characteristics.................................................. 24

4.2.1 Diesel Fuel Characteristics.................................................... 24

4.2.2 Soil Contamination........................................................... 24

4.2.3 Groundwater............................................................. 26

4.3 On-site Biotreatability Studies............................................................ 27

4.3.1 Microbiology and Microcosm Experiments.............................. 27

4.3.2 Soil Respiration Experiments.......................................... 27 
5. CONCLUSIONS AND RECOMMENDATIONS................................... 53

5.1 Conclusions ..................................................................... 53

5.2 Recommendations................................................................. 53

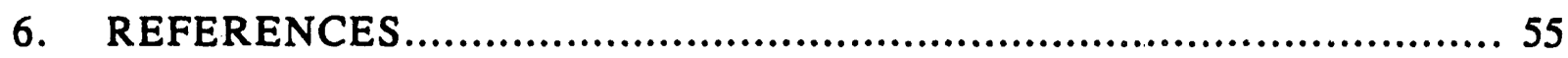

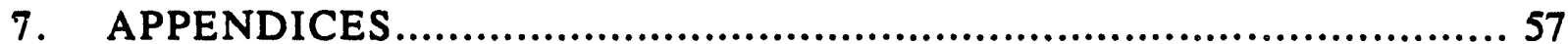

A. Descriptive Logs of Backhoe Test Pits................................................ 59

B. Listing of Samples Submitted for Laboratory Analyses.............................. 67

C. Laboratory Results for Organic Analyses........................................... 73

D. Laboratory Results for Inorganic Analyses........................................... 201 


\section{LIST OF FIGURES}

Page No.

2.1. Location map of Kwajalein Island in The Republic

of the Marshall Islands..................................................................... 6

2.2. Site map of the construction area on Kwajalein Island.................................... 7

2.3. Photograph of the construction area on Kwajalein Island and ......................... 8

3.1. Location of test pits at the proposed desalination plant area on Kwajalein

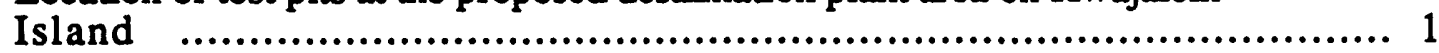

3.2. Photograph of the proposed desalination plant area on Kwajalein Island 16

3.3. Location of test pits near a diesel fuel storage tank on Kwajalein Island

3.4. Photograph of the diesel fuel storage tank on Kwajalein Island 


\section{LIST OF TABLES}

Page No.

3.1. On-site analyses of samples collected on Kwajalein Island during

February 1991

3.2. Off-site analyses of samples collected on Kwajalein Island during February

1991 and transported to ORNL

4.1. On-site analyses of saturated soil extracts from soil samples collected on

Kwajalein Island during February 1991.

4.2. Physical characteristics of soil samples collected on Kwajalein Island during February 1991

4.3. Basic physical/chemical properties of soil samples collected on Kwajalein Island during February 1991

4.4. Nutrient content in soil samples collected on Kwajalein Island during February 1991 .

4.5. Exchangeable cation content in soil samples collected on Kwajalein Island during February 1991 .

4.6. On-site analyses for physical/chemical characteristics of groundwater samples collected on Kwajalein Island during February 1991.

4.7. Basic physical/chemical properties of groundwater samples collected on Kwajalein Island during February 1991.

4.8. Macronutrient content in groundwater samples collected on Kwajalein Island during February 1991

4.9. Elemental content in groundwater samples collected on Kwajalein Island during February 1991

4.10. Concentrations of volatile and semivolatile organic compounds measured in a diesel fuel sample collected from the diesel fuel power plant by ORNL in February 1991

4.11. Field screening results for total hydrocarbons measured in soil and groundwater samples collected from the desalination plant site by ORNL

in February 1991.

4.12. Field screening results for total hydrocarbons measured in soil and groundwater samples collected from the diesel fuel tank site by ORNL in February 1991

4.13. Concentrations of total petroleum hydrocarbons measured in soil and groundwater samples collected from the desalination plant site by ORNL in February 1991 
4.14. Concentrations of total petroleum hydrocarbons measured in soil and groundwater samples collected from the diesel fuel tank site by ORNL in February 1991

4.15. Concentrations of semivolatile hydrocarbons measured in soil and grcundwater samples collected from the desalination plant site by ORNL

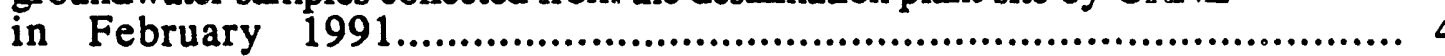

4.16. Concentrations of semivolatile hydrocarbons measured in soil and groundwater samples collected from the diesel fuel tank site by ORNL in February 1991

4.17. Concentrations of volatile hydrocarbons measured in soil and groundwater samples collected from the desalination plant site by ORNL in February 1991......

4.18. Concentrations of volatile hydrocarbons measured in soil and groundwater samples collected from the diesel tank site by ORNL in February 1991

4.19. Concentrations of heavy metals measured in soil and groundwater samples collected from the desalination plant site by ORNL in February 1991.

4.20. Concentrations of heavy metals measured in soil and groundwater samples collected from the diesel fuel tank site by ORNL in February 1991

4.21. Low-level radiochemical analyses of soil and groundwater samples collected from the desalination plant site and the diesel tank site by ORNL in February 1991

4.22. Microbiological properties of soil and groundwater samples collected on Kwajalein Island during February 1991

4.23. Results of on-site microcosm experiments conducted with soil samples collected on Kwajalein Island during February 1991

4.24. Results of on-site respiration experiments conducted with soil samples collected on Kwajalein Island during February 1991

B.1. Organics analysis listing of samples returned to ORNL from Kwajalein Island on Saturday, February 25, 1991

B.2. Organics analysis listing of samples returned to ORNL from Kwajalein Island on Saturday, March 2, 1991 70

B.3. Inorganics analysis listing of samples returned to ORNL from Kwajalein Island on Saturday, February 25, 1991

B.4. Inorganics analysis listing of samples returned to ORNL from Kwajalein Island on Saturday, March 2, 1991 
PREFACE

This document describes environmental research that is part of a field-scale project designed to demonstrate, test, and evaluate bioremediation as an environmental restoration technique for petroleum-contaminated soils on Kwajalein Island, a U.S. Army Kwajalein Atoll (USAKA) facility in the Republic of The Marshall Islands. The overall project is being managed and conducted by a muitidisciplinary team of investigators from Oak Ridge National Laboratory (ORNL), Oak Ridge Associated Universities (ORAU), and The University of Tennessee (UT). Some of the key participants are listed below.

T.L. Donaldson

R.L. Jolley

H.A. Adler

R.L. Siegrist

T.J. Phelps

N.E. Korte

D.A. Pickering

C.H. Brown

M.E. Reeves

G.W. Strandberg

J. Walker

A.V. Palumbo

R. Burlage

G. Sayler

D.C. White

R.L. Tyndall
Chemical Technology Division, ORNL (Executive Committee)

Chemical Technology Division, ORNL (Executive Committee)

Medical Division, ORAU (Executive Committee)

Environmental Sciences Division, ORNL (Executive Committee)

Institute for Applied Microbiology, UT

Environmental Sciences Division, ORNL

Health and Safety Research Division, ORNL

Chemical Technology Division, ORNL

Chemical Technology Division, ORNL

Chemical Technology Division, ORNL

Chemical Technology Division, ORNL

Environmental Sciences Division, ORNL

Environmental Sciences Division, ORNL

Center for Environmental Biotechnology, UT

Institute for Applied Microbiology, UT

Health and Safety Research Division, ORNL

This report describes the methods and results of the first phase of this project, which consisted of a preliminary assessment made by on-site characterization and biotreatability studies conducted during February 1991. 


\section{ACKNOWLEDGMENTS}

The work described herein was made possible by funding provided by the U.S. Army and administered by the U.S. Department of Energy (DOE) Hazardous Waste Remedial Actions Program (HAZWRAP). Several individuals and organizations contributed to the successful execution of this work. Gratefully acknowledged are the valuable assistance and support of the environmental representative for the U.S. Army Kwajalein Atoll (USAKA), Dr. Don Ott, and the contributions of the HAZWRAP project manager, Mr. Richard Machanoff, and the HAZWRAP site representative, Mr. Cliff Rogers. The U.S. Army Civic Action Team provided necessary support in excavation and closure of backhoe test pits. Harbert International, Inc., cooperated with space needs for a field laboratory and testing facility. Finally, also acknowledged are the collaborative spirit and effort of members of the HAZWRAP investigation team present on USAKA during this study. 


\section{SECTION 1}

\section{EXECUTIVE SUMMARY}

An environmental study was conducted during February 1991 on Kwajalein Island, a U.S. Army Kwajalein Atoll (USAKA) Base in the Republic of the Marshall Islands (RMI). This study was undertaken for the U.S. Department of Energy (DOE) Hazardous Waste Remedial Actions Program (HAZWRAP) acting in behalf of USAKA. The purpose of the study wis to determine if selected locations for new construction on Kwajalein Island were contaminated by petroleum hydrocarbons as suspected and, if so, whether bioremediation appeared to be a feasible technology for environmental restoration. Two different sites were evaluated: (1) the site of a planned freshwater production facility and (2) a site adjacent to an aboveground diesel fuel storage tank. A team of scientists and engineers from the Oak Ridge National Laboratory (ORNL) and The University of Tennessee (UT) visited USAKA during February 15-26, 1991, and conducted on-site inspection, subsurface sampling and analyses, and biotreatability experiments. The results of this work are highlighted below.

Subsurface soil materials were characterized as coral-derived sands, alkaline and nutrient deficient. Bacteria were present at concentrations of $10^{3}$ to $10^{6}$ organisms per gram (org/g) of soil. Groundwater occurred at depths of ca. $5 \mathrm{ft}$. and the water table chemistry showed no inarine influence.

Within the proposed construction zone for the freshwater production facility (a.k.a. desalination plant), total petroleum hydrocarbons (TPH) were either absent or at low levels. At some locations, there were trace to low concentrations of volatile organic compounds (VOCs) and semivolatile organic compounds (SVOCs). The concentrations of organic compounds measured were below commonly accepted reference values for assessing soil as contaminated and in need of remediation. There were no notable concentrations of heavy metal contaminants.

Characterization data for another potential construction site adjacent to an aboveground diesel fuel storage tank southeast of the old diesel power plant revealed high concentrations of diesel fuel in the soil and groundwater beneath the sitc. TPH concentrations increased from low levels near the ground surface to concentrations in the soil at the water table approaching 9000 $\mathrm{mg} / \mathrm{kg}$ (ppm). Concentrations of TPH measured were well above the commonly accepted reference values of 10 to $100 \mathrm{mg} / \mathrm{kg}$ for assessing soil as contaminated and in need of remediation. There were only trace to low concentrations of VOCs and SVOCs. There were no notable concentrations of heavy metal contaminants.

Biotreatability experiments suggested that microorganisms within the subsurface at those locations where petroleum contamination was present were adapted and able to degrade the hydrocarbon contaminants in the soil. In contrast, microorganisms in the uncontaminated areas were not adapted nor were they readily capable of biodegrading fresh hydrocarbons.

Results of this investigation indicate that there are petroleum-contaminated soils on Kwajalein Island and bioremediation appears to be a viable environmental restoration technique. Further experimentation and field demonstration are required to determine the design and operating conditions that provide for optimum biodegradation and restoration of the petroleumcontaminated soils. 


\title{
SECTION 2
}

\author{
INTRODUCTION
}

\subsection{BACKGROUND}

The U.S. Army Kwajalein Atoll (USAKA) Base is located on Kwajalein Island in the Republic of the Marshall Islands (RMI) which are in the west central Pacific Ocean. Kwajalein Island is approximately 2100 nautical miles (nmi) southwest of Honolulu, Hawaii, and $700 \mathrm{nmi}$ north of the equator (Fig. 2.1). Kwajalein Atoll is the largest enclosed lagoon in the world and consists of approximately 100 small islands with a total area of $5.6 \mathrm{mi}^{2}$. Kwajalein Island is approximately $3.5 \mathrm{mi}$ long by 0.3 to $0.5 \mathrm{mi}$ wide with a land surface area of $1.2 \mathrm{mi}^{2}$. The population of the Base is ca. 3000, including Army personnel, a host of subcontractors, and family personnel.

The United States and the RMI recently negotiated a compact of free association allowing the United States exclusive use of 11 islands within the Kwajalein Atoll. The compact stipulates that the environment of Kwajalein Atoll will be protected in accordance with U.S. environmental laws (e.g., RCRA, CERCLA, TSCA, CWA). The mechanism for implementing and verifying compliance is not clear, however. For example, the U.S. Environmental Protection Agency (EPA) (i.e., Region IX) determined that it has no regulatory authority within Kwajalein Atoll.

Various potentially environmentally harmful materials have been handled on Kwajalein Island during the past 50 years, and the potential release of hazardous substances through container and piping s sstem leaks, surface spills, and other potentially inadequate material handling and waste management practices may have resulted in contaminated soil and groundwater in the vicinity of the planned construction sites. Consistent with environmental requirements and standard practices in the United States, the proposed construction areas had to be investigated to determine the extent and magnitude of any contamination. If contamination was discovered, the need and extent of environ'nental restoration had to be evaluated and implemented as necessary and appropriate. To 'acilitate accomplishment of the required environmental work, USAKA commissioned HAZWRAP in 1990 to assist with and administer the various environmental projects.

One of the early HAZWRAP projects was to determine the extent and magnitude of petroleum hydrocarbon contamination adjacent to diesel-powered generating stations, storage tanks, and piping systems. This was a high-priority effort since several construction projects were planned by USAKA to occur on on Kwajalein Island during the next 5 years in the vicinity of these potential contamination sources, including the construction of a freshwater production facility (a.k.a., desalination water treatment plant) scheduled for FY1991/1992. These proposed construction sites had to be investigated and assessed to be uncontaminated or restored prior to proceeding with construction activities. It was suspected that soil and groundwater contamination by petroleum hydrocarbons and other organics would be encountered and would require environmental restoration.

Given the remoteness of Kwajalein Island, the lack of sophisticated remediation technologies and waste disposal facilitiec on-site, as well as the amenability of petroleum hydrocarbons to biodegradation, USAKA requested through HAZWRAP that a project be initiated to evaluate the feasibility of using bioremediation for environmental restoration of contaminated sites in Kwajalein Atoll. If it appeared feasible, a technology demonstration would then be initiated to document this feasibility and provide design, operation, and performance data for full-scale 
remediation on the atoll. In January 1991, HAZWRAP commissioned a team of scientists and engineers from Oak Ridge National Laboratory (ORNL), Oak Ridge Associated Universities (ORAU), and The University of Tennessee (UT) to conduct a bioremediation demonstration on Kwajalein Island.

\subsection{SYNOPSIS OF SITE CONDITIONS}

Information available describing the general site conditions of Kwajalein Island was summarized in documents describing prior investigations in the atoll and various construction related activities on Kwajalein Island [1-4]. Highlights of this information are given below.

Kwajalein Atoll consists of sedimentary coral limestone that caps a seamount and extends above the ocean floor [1-2]. The surface of the mass is very irregular and generally is submerged below sea level, while around the periphery is a higher ridge of coral which frequently extends above the water surface. This formation has yielded a crescent-shaped chain of islands surrounding a relatively shallow lagoon. Kwajalein Island, the largest of the chain, lies at the southeast end of the atoll. The land surface topography of Kwajalein Island is level. There has been some ground-filling on the northern and eastern sides of the island over time. The northem portion of the ccnstruction area, including that of the proposed desalination plant, appears to be located in a filled area.

Preliminary soil borings in the vicinity of the fuel farm, about $0.3 \mathrm{mi}$ east of the desalination construction site, revealed subsurface conditions composed of tan, poorly graded to silty coral sands (SP-SM). With depth, well-graded sands (SW) and silts (ML) were encountered. Materials encountered during boring were reported to have an "obvious petroleum or hydrocarbon odor" [3].

Groundwater under $\mathrm{K}$ wajalein Island was reported to exist in a freshwater surface lens typical of coral atolls. The water table elevation is typically within $+/-1 \mathrm{ft}$ of the sea level and varies with tidal fluctuations. For the construction area, this information suggested that groundwater would be encountered at approximately 6- to 8-ft depths.

Preliminary information regarding the types of activities occurring on the island, as well as limited results of on-site soil and groundwater investigations, suggested that the construction site for the desalination plant and other nearby sites might be contaminated with petroleum hydrocarbons [3-4]. It was believed that the contamination would be primarily diesel fuel associated with power generation, but contamination by other hydrocarbons (e.g., jet fuel, gasoline, solvents) would be possible. In addition, there could be other organic and inorganic contaminants.

\subsection{OBJECTIVES AND SCOPE}

The first phase of the bioremediation demonstration described herein involved site characterization and on-site treatability studies to determine the nature and magnitude of contamination present and to determine if bioremediation appeared to be a feasible technology for environmental restoration of petroleum hydrocarbon-contaminated sites in Kwajalein Atoll. To accomplish this goal, a team of scientists and engineers visited USAKA to conduct on-site inspection, subsurface sampling and analyses, and biotreatability experiments. The objectives of the work were to characterize subsurface conditions and assess the feasibility of bioremediation at one or more sites within the construction area (Fig. 2.2). It was acknowledged that the purpose of this work was not to fully delineate the extent or source of contamination at the construction site for the desalination plant or at any other site on Kwajalein 
Island. A detailed workplan was developed and approved by HAZWRAP prior to conduct of this work [5].

The study described herein focused on the planned construction area located in the center of USAKA on the atoll side (Fig. 2.3). This area encompasses approximately 20 acres. Within this general construction area, a primary site of interest was the location of a new desalination plant planned for construction during FY1991/1992. This site encompasses approximately 0.3 acres adjacent to the lagoon. Additional areas of interest were adjacent to an old diesel fuel power plant in the center of the planned construction area (Fig. 2.2).

The data quality objectives for this work were developed after consideration of the study purpose and data users. The study was a feasibility assessment, and the principal users of data generated were the technical team responsible for design and conduct of the bioremediation technology demonstration. Because of logistical and technical problems associated with shipping soil materials into the United States from RMI, the remote location of the site, and the need for real-time information to enable field interpretation and decision-making, considerable work had to be carried out on-site using field portable apparatus, instrumentation, and techniques. Given the preceding, the data quality objectives of this field work were HAZWRAP Level AVB. For samples transported to laboratories at ORNL, HAZWRAP Level $\mathrm{B} / \mathrm{C}$ was to be attained [6-7].

\subsection{REPORT ORGANIZATION}

A discussion of the materials and methods of the site characterization and on-site treatability experiments is presented in Section 3. The results are summarized in Section 4, and conclusions and recommendations are given in Section 5 . It should be noted that off-site treatability experiments are not included; these will be presented in a forthcoming report. 


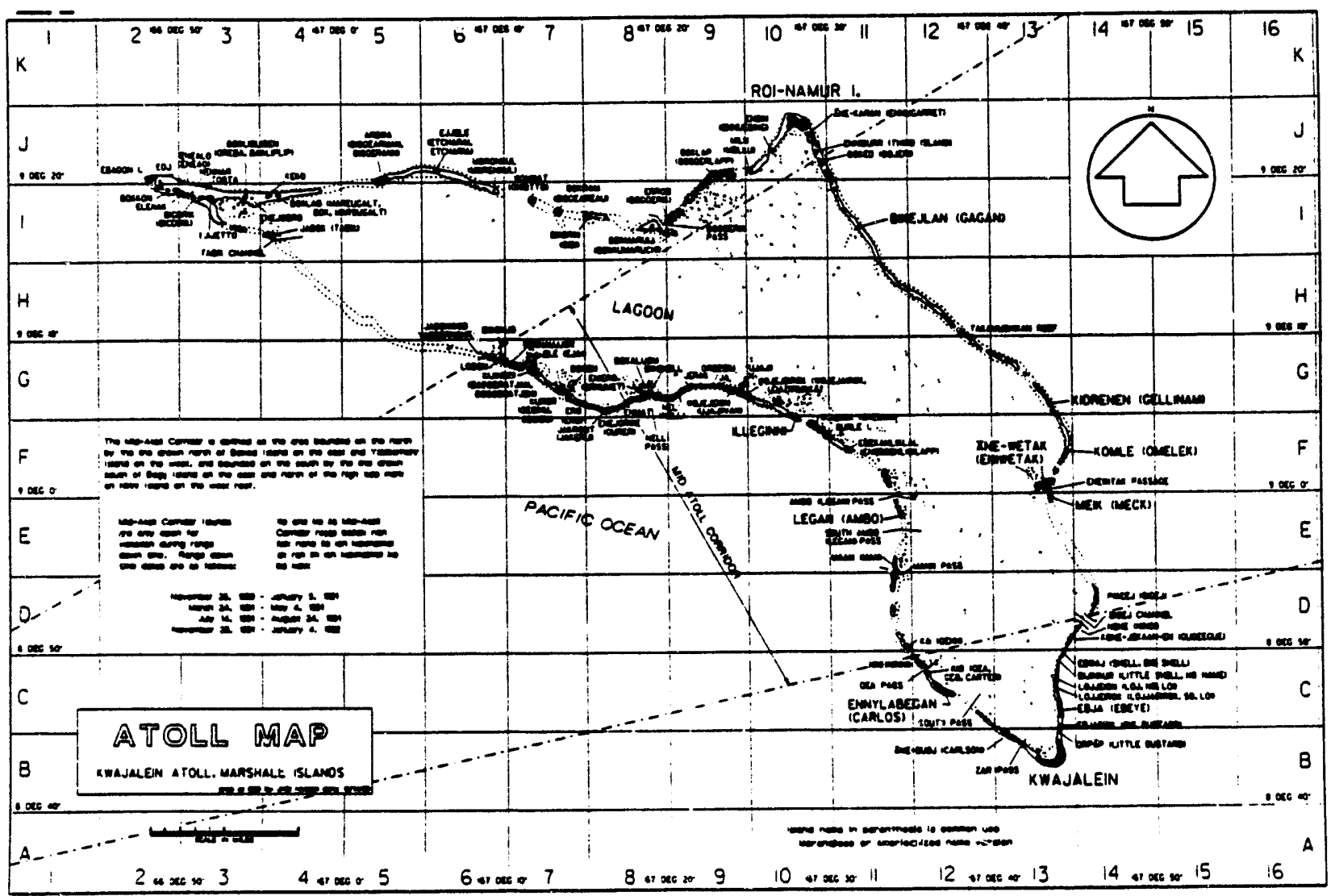

Fig. 2.1. Location map of Kwajalein Island in The Republic of the Marshall Islands (ORNL DWG 91-92748). 


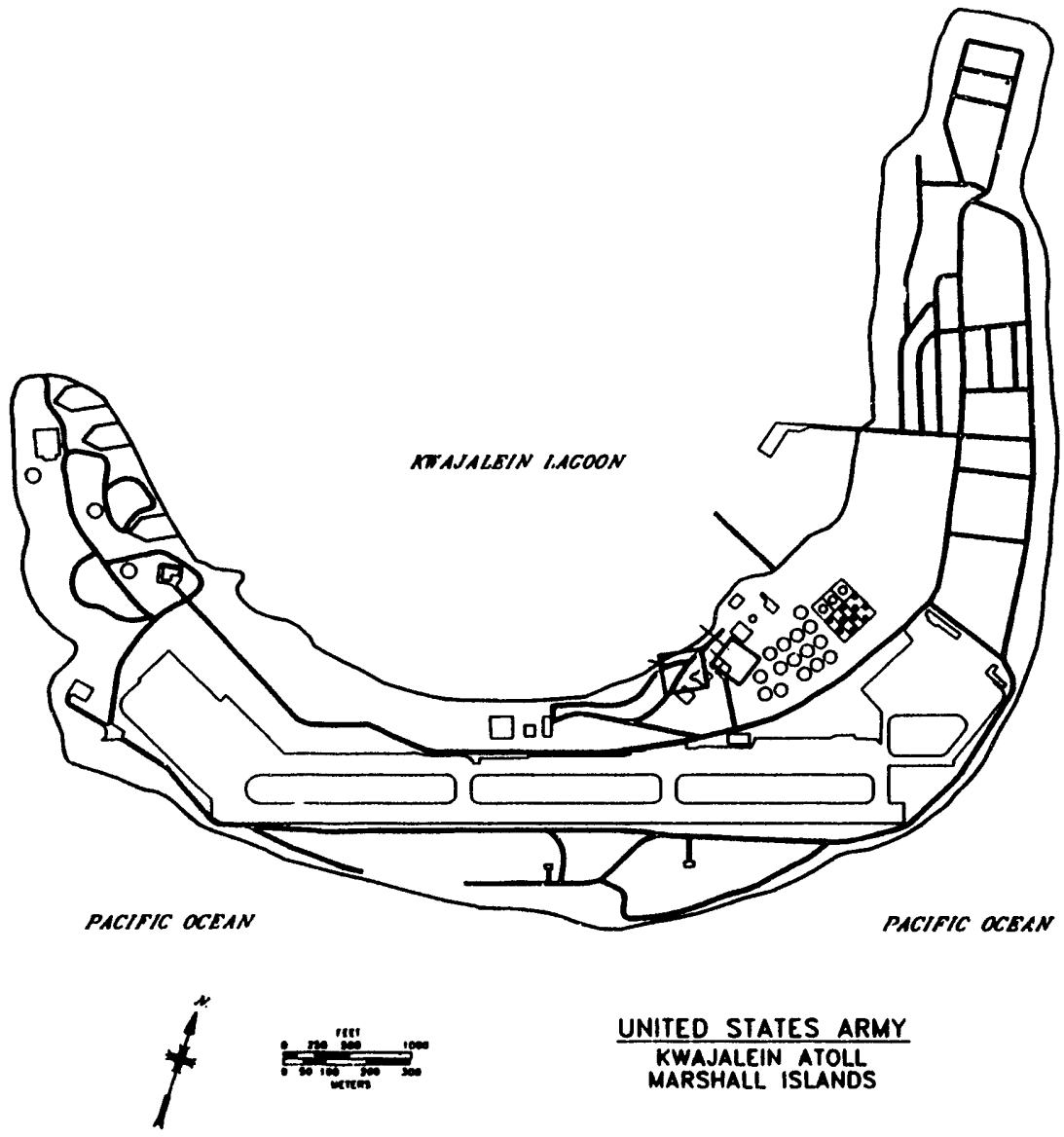

Fig. 2.2. Site map of the construction area on Kwajalein Island (ORNL DWG 91-12745). 


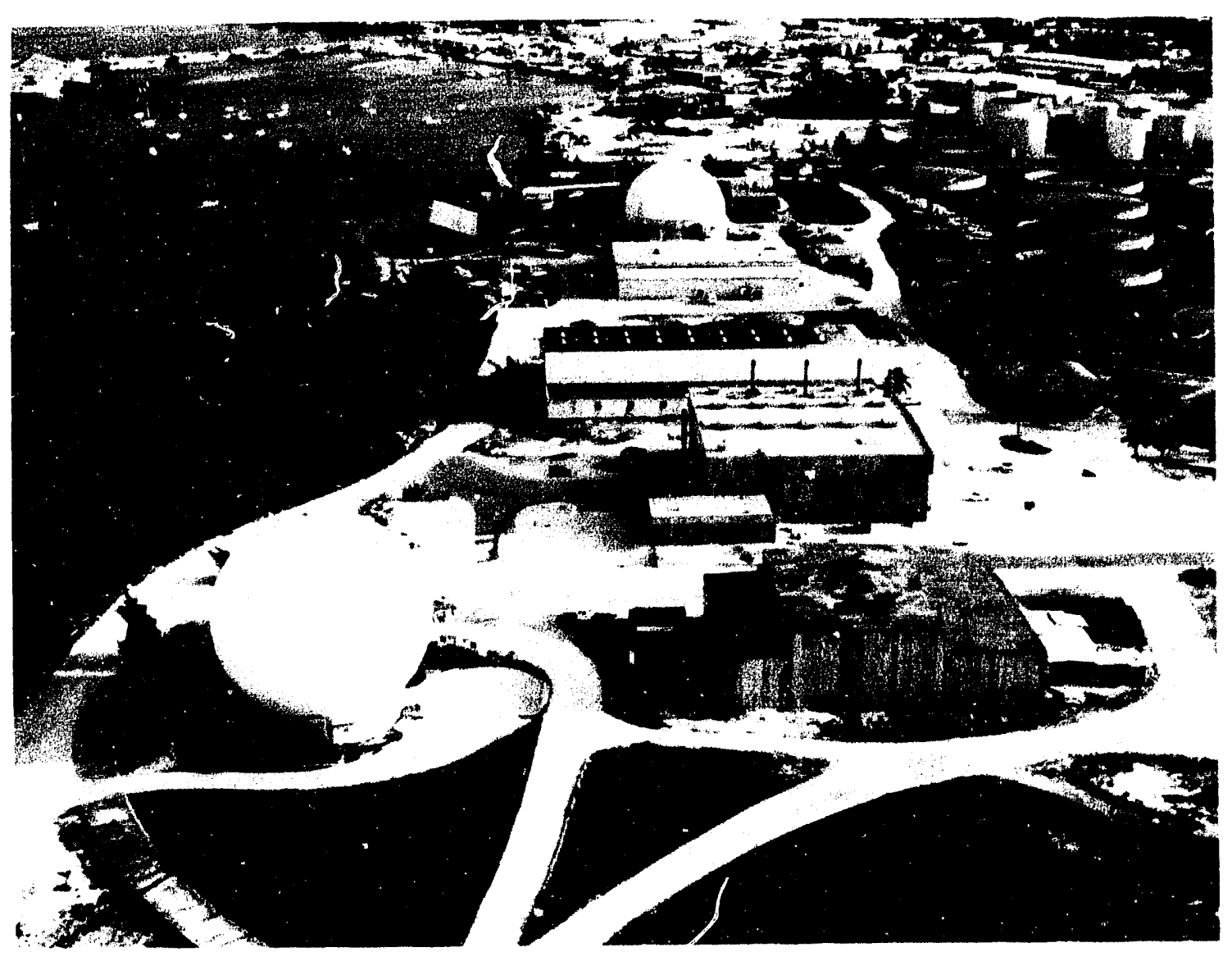

Fig. 2.3. Photograph of the construction area on Kwajalein Island (ORNL DWG 6631-91). 


\section{SECTION 3}

\section{MATERIALS AND METHODS}

\subsection{INTRODUCTION}

This investigation was conducted during a visit to Kwajaiein Atoll by a four-person team from ORNL and UT. This team comprised an environmental engineer (R.L. Siegrist), an analytical chemist (N.E. Korte), a geologist (D.A. Pickering) from ORNL, and a microbiologist from UT (T.J. Phelps). A plan was developed for conduct of this work and submitted to HAZWRAP prior to the site visit in February 1991 [5]. This workplan detailed the materials and methods envisioned to be necessary to accomplish the proposed objectives. It also addressed data quality, decontamination and waste management, and health and safety. This section describes the actual materials and methods used during conduct of the on-site testing and experiments as well as the off-site characterization analyses conducted at ORNL.

\subsection{SITE PHYSICAL CHARACTERISTICS}

\subsubsection{Physical Setting}

General observations were made of site features and characteristics relevant to implementation of a bioremediation technology demonstration. These included land use, topography, and subsurface conditions. A variety of topographic and utility maps and aerial photographs for the area acquired from USAKA resources were reviewed.

\subsubsection{Soil and Geology}

Generalized soil and geology characteristics were preliminarily assessed through available published resource information. These included reports by the U.S. Army, the University of Hawaii, and others [1-4].

During the February site investigation, six test pits were made within the construction area using a tractor-mounted backhoe. Three test pits were dug in the desalination plant construction area (Fig. 3.1 and 3.2), while three were made in the vicinity of an aboveground diesel fuel storage tank (Fig. 3.3 and 3.4). Subsurface conditions were observed and recorded with depth within each test pit. A pencil-type soil thermometer was pressed into the sidewall of each pit at several locations to determine soil temperature with depth.

Soil properties were determined by soil sampling and on-site analyses as well as through transportation of samples to ORNL for controlled laboratory analyses. The soil sampling and analyses for basic physical and chemical properties of the soils in the study areas on USAKA are described below. Contaminant sampling and analyses are descn .ed in Section 3.3.

\subsubsection{Soil Sampling}

Soil samples for general physical and chemical properties were collected at selected depths from the test pit sidewalls using a precleaned stainless steel trowel. In test pits (TPs) 1 to 4 , soil samples were collected near the surface, midway from the surface to the water table, and at the water table. In TPs 5 and 6, soil samples were collected at the water table only. Soil samples for general physical and chemical analyses were containerized in zip-closure 
polyethylene bags and labeled accordingly. All samples were placed in coolers containing "blue ice" to maintain the soil temperature near $4^{\circ} \mathrm{C}$.

\subsubsection{Soil Analyses}

On-site Soil Analyses: Soil analyses were made on-site at a temporary laboratory set up in an existing building near the investigation area. Soil analyses were conducted as summarized in Table 3.1 and described below.

Soil water content was determined gravimetrically in the field by oven drying a $100-\mathrm{g}$ (field moist weight) sample of soil at $105^{\circ} \mathrm{C}$ for $24 \mathrm{~h}$.

Soil analyses for $\mathrm{pH}$, conductance, nitrate, and phosphate were performed on saturation extracts. The saturation extract was prepared by a standard U.S. Department of Agriculture (USDA) procedure except that samples did not equilibrate overnight prior to extraction. Limits on space and equipment made the waiting period difficult. Furthermore, the waiting period is to permit water to penetrate clays and release some of the ions present. The coarse-grained nature of the crushed coral suggests that there would be no difference between samples that were extracted within a few minutes of preparation and those permitted to equilibrate overnight.

Approximately $50 \mathrm{~g}$ of field moist soil were used to prepare each extract. The sample size was limited in several cases and the coarse and heterogeneous nature of the material indicated that variations in the water needed to prepare an extract would be encountered. Moreover, the saturation extract procedure relies on the judgment of the sample preparer. Coarse-grained samples are very difficult to judge because few clay or silt particles adhere to the spatula during preparation of the extract. These circumstances were expected to introduce additional variability into the analytical results.

The saturation extracts were analyzed on-site for $\mathrm{pH}$, specific conductivity, $\mathrm{NO}_{3}-\mathrm{N}$, and $\mathrm{PO}_{4}-$ $\mathrm{P}$. Specific conductance and $\mathrm{pH}$ were measured by means of a $\mathrm{pH} /$ conductivity meter (Yellow Springs Instrument Co.). The meter was calibrated within a few minutes of the time of analysis. The temperature of the calibration solutions was within two degrees of the temperature of the samples. Nitrate was determined with a chemical test kit (Hach Chemical Co.). That procedure employs the cadmium reduction of nitrate to nitrite followed by reaction with chromotropic acid as a color reagent. Measurements were made with a UV/visible spectrophotometer. Phosphate was also determined with a chemical test kit (Hach Chemical Co.). That procedure employs the molybdenum blue method in which orthophosphate is reacted with molybdate to form a phosphomolybdate complex. Ascorbic acid is then used to reduce the complex and produce an intense blue color that is quantified with the spectrophotometer.

Off-site Soil Analyses: Soil samples were also containerized and shipped to ORNL under permit from the USDA. Off-site testing was conducted for water content, grain size distribution, exchangeable cations, organic carbon, nitrogen species, phosphate, gross alpha, and gross beta. The analyses listed in Table 3.2 were conducted according to standard practices [4-13].

\subsubsection{Hydrogeology}

Groundwater conditions at the site were preliminarily evaluated based on the results of prior investigations on the island [1-4]. The depth and general physical/chemical composition of the 
groundwater in the study areas on Kwajalein Island were determined by sampling and analyses as described below. Groundwater contamination information is provided in Section 3.3.

\subsubsection{Groundwater Sampling}

During the February 1991 site visit, groundwater depth and composition were determined in six test pits. These determinations were accomplished as follows. Excavation of each test pit was made to the capillary fringe just above the groundwater table. Then the ambient groundwater table was exposed by hand using a precleaned tile spade. This exposure was done in an attempt to minimize disturbance of the groundwater. The depth to groundwater from the ground surface was measured using a steel tape. Observations of the water table surface were made to determine if any floating fuel was present. Samples of groundwater were collected by creating a srnall sump in the bottom corner of each test pit. A hand pump was used to fill a 1-L vacuum flask. The contents of the flask were then transferred to individual sample containers. Samples for VOCs were collected by immersing a $40-\mathrm{mL}$ vial in the sump.

One sample of surface water from the Kwajalein Atoll lagoon was collected by dipping a container into the lagoon in a rocky area near shore, northwest of the proposed desalination plant area. Collection of a rainwater sample was planned but was not performed because of insufficient rainfall.

\subsubsection{Groundwater Analyses}

On-site Groundwater Analyses: Water samples were taken to a temporary field laboratory and analyzed on-site for specific conductance, $\mathrm{pH}$, and nutrients as described for the saturation extracts in Section 3.2.2.2 (Table 3.1). Specific conductance and $\mathrm{pH}$ were measured by a $\mathrm{pH} /$ conductivity meter. Alkalinity was measured with a digital titrator. Nitrate and phosphate were determined with a chemical test kit.

Off-site Groundwater Analyses: Water samples were also shipped to ORNL for analyses as summarized in Table 3.2. These samples were placed in coolers containing blue ice to maintain the samples near $4^{\circ} \mathrm{C}$. Shipping of the coolers to ORNL occurred by air carrier.

\subsection{SITE CONTAMINATION CHARACTERISTICS}

The methods used to sample and analyze for soil and groundwater contamination are described in this section.

\subsubsection{Diesel Fuel Characteristics}

Since diesel fuel was suspected to be the principal contamination in the study areas, a sample of diesel fuel was collected from the fuel storage tanks on USAKA. The fresh fuel was containerized in amber, $40-\mathrm{mL}$ VOA glass vials with Teflon-sealed septa. These were packed in vermiculite inside a secondary glass container and refrigerated for transport to the off-site laboratory for analysis. In addition, subsamples of this material were used for the on-site experimental work (i.e., microcosm studies and respirometer studies). 


\subsubsection{Soil Contamination}

\subsubsection{Soil Sampling}

Soil gas samples were not collected because of the difficulty involved with installing the gas sampling device in the dense fill in the study areas. Based on the results with the barrel auger, it was concluded that the soil gas sampling tool (e.g., Xitech push probe) would be unable to penetrate the crushed coral fill; however, soil gas sampling in certain natural areas on $\mathrm{K}$ wajalein Island and other islands in the atoll (e.g., Roi-Namur) may be possible.

Soil samples for contamination properties were collected at selected depths from the test pit sidewalls using precleaned stainless steel utensils. In TPs 1 to 4, soil samples were collected near the surface, midway from the surface to the water table, and at the water table. In TPs 5 and 6, soil samples were collected at the water table only. Soil samples for analyses of volatile organic compounds (VOC), semivolatile organic compounds (SVOCs), and total petroleum hydrocarbons (TPH) were collected using a stainless steel microcoring device (Manufacturing Sciences, Inc.). For each of these three analysis groups, duplicate samples were containerized in amber, $40-\mathrm{mL}$ Teflon-sealed glass vials. The samples were labeled accordingly and placed in zip-closure polyethylene bags. Samples for heavy metals were collected with a stainless steel trowel and packed into amber, 125-mL Teflon-sealed glass jars. All samples were placed in coolers containing blue ice to maintain the soil temperature at near $4^{\circ} \mathrm{C}$.

\subsubsection{Soil Contamination Analyses}

On-site Soil Contamination Analyses: Soil samples were screened on-site for organic contamination as follows. The first method involved a solvent extraction and infrared analysis. Five $\mathrm{g}$ of field moist soil were extracted with $10 \mathrm{~mL}$ of 1,1,2-trichloro-1,2,2-trifluoroethane if the sample appeared uncontaminated. Smaller weights (down to a few tenths of a gram) were used for soil samples suspected of being highly contaminated. The extract was then measured on an infrared spectrophotometer (Foxboro-Wilks 1ACVF). The measured absorbance of the extract was compared to a working curve made of known amounts of diesel fuel dissolved in the extraction solvent. The diesel fuel used in the standardization was a sample of the diesel fuel used in the power plant on Kwajalein Island.

The second method involved a chemical test kit (Hanby Analytical Laboratories). This test kit measurement is based on the Friedel-Crafts acylation. This reaction involves the combination of an aromatic compound with an acid chloride catalyzed by a Lewis acid such as aluminum chloride to yield a colored product. The hue and intensity of the color are determined by the nature and concentration of the aromatic compounds in the sample. Carbon tetrachloride is the normal extraction reagent. For use on Kwajalein Island, the test kit procedure was modified by substituting 1,1,2-trichloro-1,2,2-trifluoroethane for the carbon tetrachloride. Upon returning to ORNL from the field, diesel fuel standards were prepared in carbon tetrachloride and 1,1,2trichloro, 1,2,2-trifluoroethane. A literature search revealed that the extraction efficiencies of the two solvents are comparable. However, color development in the two solvents was not identical. Thus, a calibration curve should be constructed when a solvent different from carbon tetrachloride is used. Otherwise, it is suitable to use the color comparison charts provided with the kit. 
Off-site Soil Contamination Analyses: Soil samples were also containerized and shipped to ORNL under permit. from the USDA. Off-sice testing was conducted for TPH, VOCs, SVOCs, and heavy metals. Samples were also screened for gross alpha and beta radioactivity. The analyses listed in Table 3.2 were conducted according to standard practices [4-13].

\subsubsection{Groundwater Contamination}

\subsubsection{Groundwater Sampling}

Groundwater samples for contaminant characterization were collected from each of the backhoe test pits. Samples for VOC, SVOC, and TPH analyses were cullected by immersing $40-\mathrm{mL}$ amber glass vials with Teflon septum lined caps, into the sampling sump created in the bottom of each pit. Samples for heavy metals were collected by using the vacuum flask collection technique described above. All groundwater samples were labeled accordingly and then placed in coolers containing blue ice.

\subsubsection{Groundwater Contamination Analysis}

Qn-site Groundwater Contamination Analyses: Analyses of groundwater for organic contamination were made on-site by two methods as follows.

The first method involved a solvent extraction and infrared analysis. Ten $\mathrm{mL}$ of groundwater were extracted with $10 \mathrm{~mL}$ of 1,1,2-trichloro,1,2,2-trifluoroethane. The extract was then measured on an infrared spectrophotometer (Foxboro-Wilks 1ACVF). The measured absorbance of the extract was compared to a working curve made of known amounts of diesel fuel dissolved in the extraction solvent. The diesel fuel used in the standardization was a sample of the diesel fuel used in the power plant at Kwajalein.

The second method involved the chemical test kit employing the Friedel-Crafts acylation reaction (Hanby Analytical Laboratories). An aliquot of the extract used in the infrared analysis described above was used for this procedure.

Off-site Groundwater Analyses: Groundwater samples were containerized and shipped to ORNL for further testing. These samples were analyzed for organics (VOCs, SVOCs, TPH) and heavy metals by standard practices [4-13].

\subsection{ON-SITE BIOTREATABILITY STUDIES}

\subsubsection{Microbiology and Microcosm Experiments}

An important question when contemplating the use of bioremediation on Kwajalein Island is whether microorganisms exist that are capable of degrading the hydrocarbon contaminants. To address this question, the level of indigenous microorganisms was quantified, and a series of bench-scale experiments were conducted using samples of contaminated soil and qualitative microbiological techniques.

Soil samples for microbiologicai analyses were collected using sterilized utensils. All utensils used to contact the soil were precleaned by detergent wash and deionized water rinses, then flamed with isopropanol immediately prior to sampling. The soil samples were removed from the test pit using a sterile stainless steel trowel and placed in sterile polyethylene bags, polypropylene bottles, and glass test tubes. These samples were transported to the field 
laboratory on USAKA and immediately prepared for analysis. Additional sample materials were placed in coolers containing blue ice to maintain the soil temperature near $4^{\circ} \mathrm{C}$ pending transport to ORNL for further analyses.

Microbial abundance was assessed by plate count methods using an extremely dilute and a less dilute complex medium. All chemicals used were reagent grade (Mallinckrodt or Sigma Chemical Co.). Resi-analyzed glass distilled solvents and reagents were also used (J.T. Baker Chemical Co.). Total aerobic bacterial spread-plate counts were performed in duplicate with serial dilutions using a medium containing $10 \mathrm{mg} / \mathrm{L}$ each of peptone, trypticase, yeast extract and glucose with noble agar (PYTEG), and a medium containing $1000 \mathrm{mg} / \mathrm{L}$ of each nutrient (Balkwill). All media contained trace minerals including selenium and molybdate as well as a dilute vitamin mix with a $10-\mathrm{mM}$ bicarbonate plus a 2-mM phosphate buffer. All media were prepared at IT and transported on-site in sealed, sterile containers. Jars containing the sterile agar media were microwave-heated in the field to melt the agar medium. Approximately $10 \mathrm{~mL}$ of liquified agar medium was added to sterile petri dishes which were then held in an "ltraviolet light-irradiated cabinet. Serial dilutions of sediment slurries were spread onto the agar surfaces. Experiments were incubated at ambient temperatures (i.e., 21 to $24{ }^{\circ} \mathrm{C}$ ). Results were analyzed after 2,4 , and 6 days. After incubation, all petri dishes and dilution tubes were microwaved and then burned prior to on-site disposal.

A selected number of samples were collected from the various test pits and returned to ORNL for further analyses of microbiology characteristics.

Enrichment-broth tubes containing $0.001,0.1$, or $2 \mathrm{~g}$ of soil were established with various media. Media included the dilute PTYEG noted above and a basal salts medium. Both media types were used at two different pH's, 7.4 and 8.5. Furthermore, the salinity was varied from fresh water, brackish (i.e., $1 \%$ salt), and marine (i.e., 3\% salt). Diesel fuel was added as a carbon source. The enrichment tubes were incubated in the inverted position and growth was monitored over 2 to 6 days. Microbial activity was assessed by observations of turbidity, gas bubbles, and color change. Five to $30 \mathrm{uL}$ of gaseous headspace of representative broths exhibiting growth and control vials were analyzed on-site with a field gas chromatograph (Photovac 10S50) equipped with a photoionization detector. At the end of the experiment, all broths were microwaved and then discharged to the sewage treatment plant.

\subsubsection{Soil Respiration Experiments}

Another approach to assessing bioremediation potential involves measurement of soil respiration rates with material from a contaminated site. To accomplish this, bench-scale experiments were conducted using constant-volume respirometer techniques. Samples of soil materials (ca. $200 \mathrm{~g}$ ) were collected from various depths and locations and placed in field portable respirometers (ca. 1-L each). Three separate experimental runs were made using soil sample composites from TPs 1,4 , and 5 . In each case, replicated treatments were used to assess biodegradability of ambient organic contaminants as estimated by oxygen uptake measurements. The individual treatment conditions included controls (i.e., empty reaction vessel), unamended contaminated soil, contaminated soil spiked with fertilizer nutrients (i.e., $\mathrm{N}, \mathrm{P}, \mathrm{K}$, and micronutrients), and contaminated soil spiked with nutrients and fresh diesel fuel. The respirometers were incubated under ambient conditions (ca. 21-24ㅇ)

Cumulative oxygen uptake was measured over several days by manometric techniques. Carbon dioxide evolved was trapped in $3 \mathrm{~mL}$ of a $10 \% \mathrm{KOH}$ contained in a vial within each respirometer. The cumulative oxygen uptake was computed using a flask constant calculated for the respirometers $\left(72.1 \mathrm{uL} / \mathrm{mm}\right.$ pressure change). The cumulative $\mathrm{CO}_{2}$ evolved was 
estimated by placing the $\mathrm{KOH}$ from each respirometer in a 5-mL syringe and then acidifying it with $2 \mathrm{~mL}$ of $6 \mathrm{M} \mathrm{HCL}$. The gas volume produced during incubation for several hours was then estimated.

\subsection{GENERAL WORK CONDUCT}

\subsubsection{Decontamination and Waste Management}

All apparatus, utensils, and tools that contacted the subsurface were decontaminated after each use. Decontamination occurred at a designated location(s) adjacent to the test pit locations. Decontamination consisted of a detergent wash, tapwater rinses, and a deionized water rinse. The deionized water was prepared on-site using a Nanopure water purifier with Kwajalcin tapwater as the feed water.

At the end of an event or each day of activity, quality control samples were collected to verify that decontamination was successfully accomplished. At a minimum, all quality control samples were analyzed for VOCs, SVOCs, and lead.

Minimal waste liquids and solids were generated during the on-site activities. These were packaged, labeled, and handled in accordance with the approved health and safety plan.

\subsubsection{Field Data Management and Recording}

Project logbooks were maintained throughout the course of the field work. The materials and methods of all field activities were documented in detail. Throughout the course of the field investigation, photographs were taken to record important visual information.

\subsubsection{Health and Safety}

The health and safety plan developed by the U.S. Army Environmental Hygiene Agency (USEHA) in October 1990 for USAEHA Study 38-26-0365-90/91, Soil and Groundwater Contamination Study, Kwajalein Atoll, was followed in principal [4]. The sections pertinent to the workplan are $1,3,4 \mathrm{~d}, 4 \mathrm{e}, 5 \mathrm{a}(2), 5 \mathrm{a}(3), 5 \mathrm{a}(6), 5 \mathrm{~b}, 5 \mathrm{c}, 5 \mathrm{e}, 5 \mathrm{f}, 5 \mathrm{~g}$, 5h, and Table 2 . A copy of the approved health and safety plan was maintained on-site during the conduct of this work. 

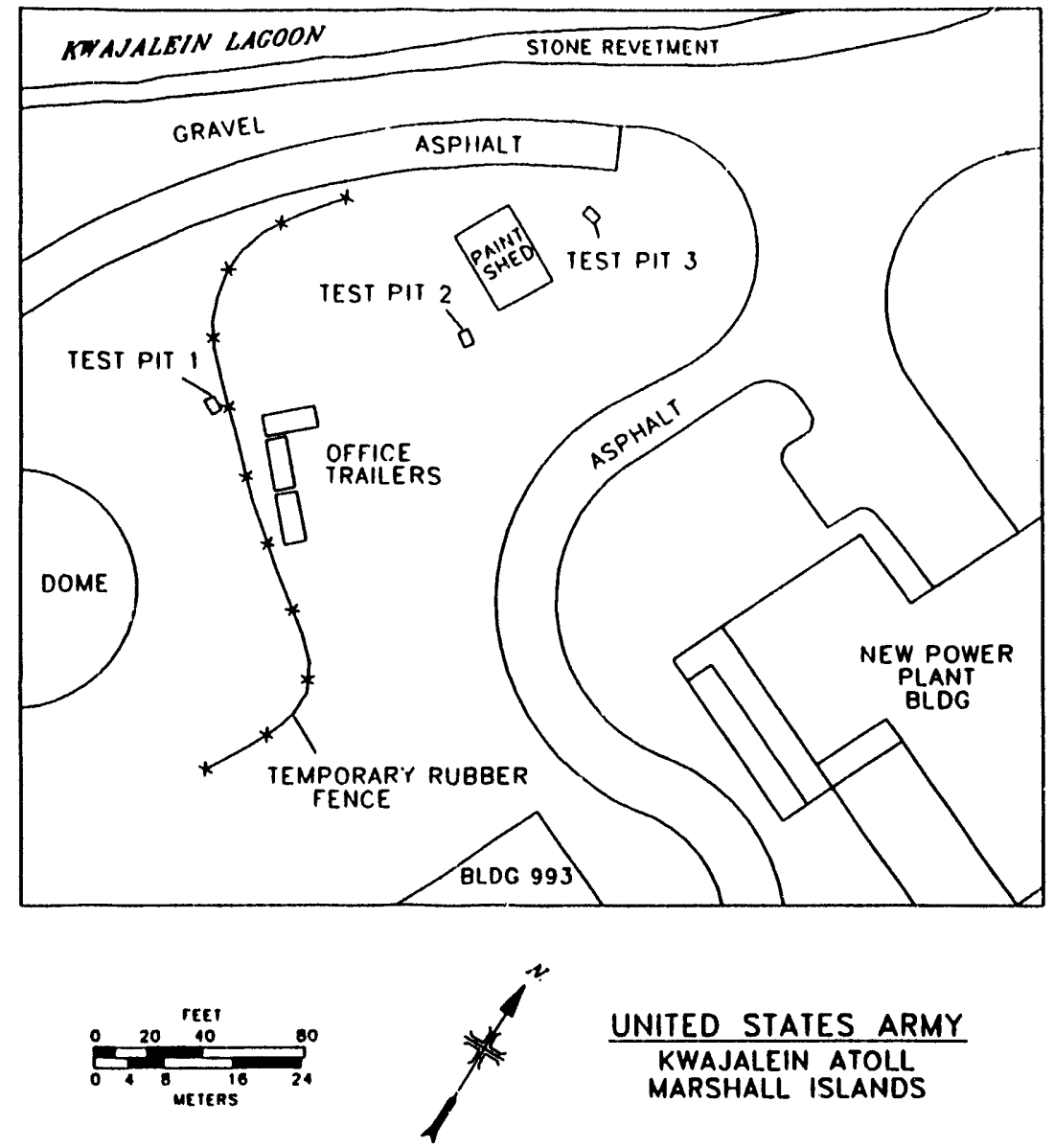

UNITED STATES ARMY

KWAJALEIN ATOLL

MARSHALL ISLANDS

Fig. 3.1. Location of test pits at the proposed desalination plant area on Kwajalein Island (ORNL DWG 91-12747).

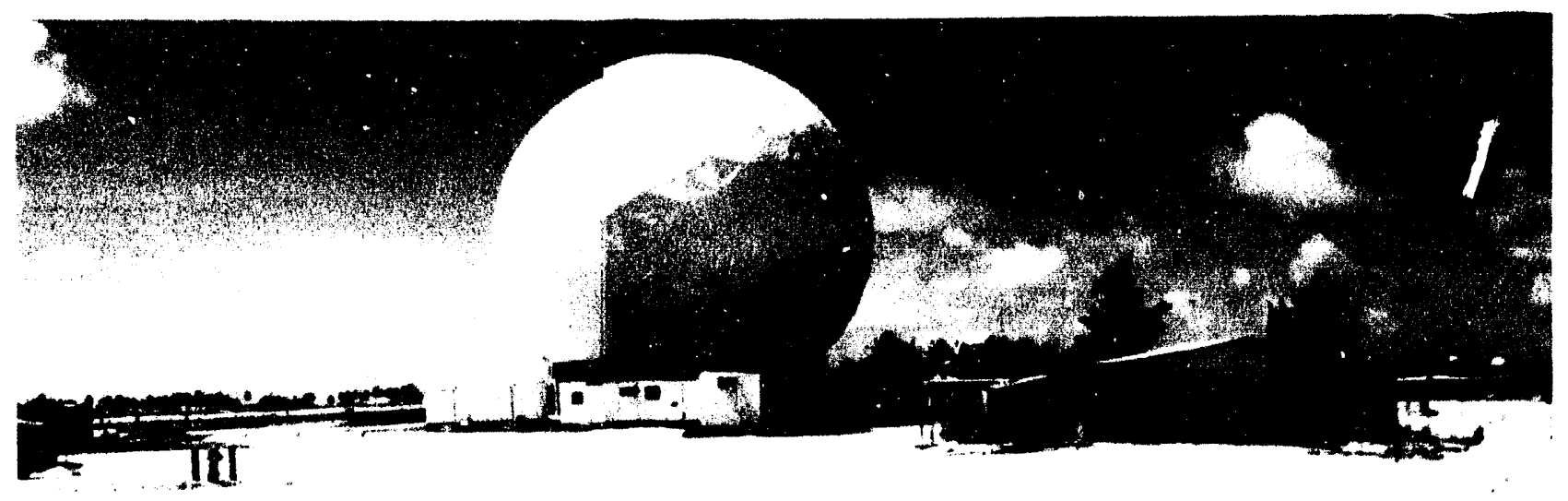

Fig. 3.2. Photograph of the proposed desalination plant area on Kwajalein Island (ORNL DWG 91-6632-91). 


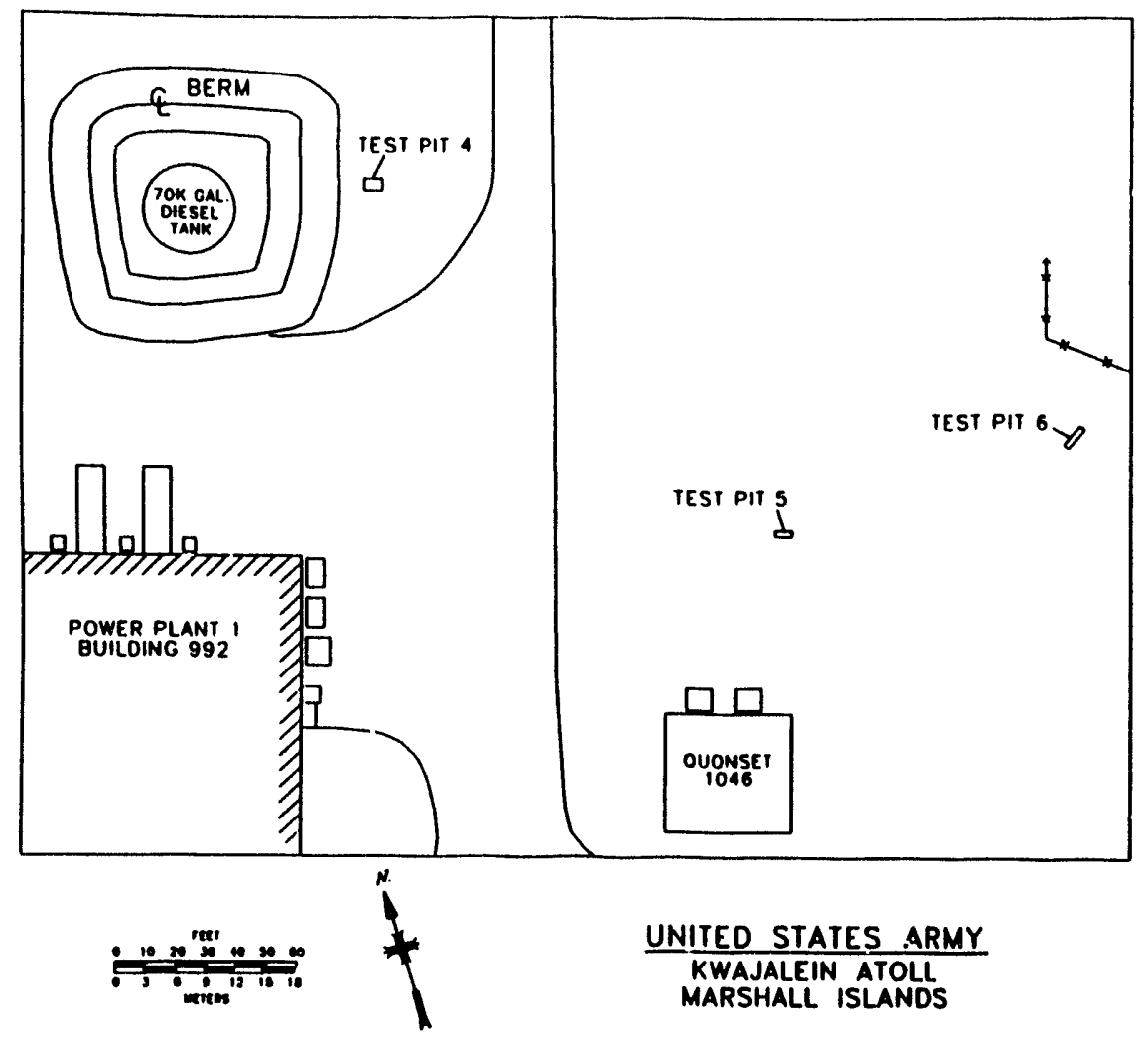

Fig. 3.3. Location of test pits near a diesel fuel storage tank on Kwajalein Island (ORNL DWG 91-12746).

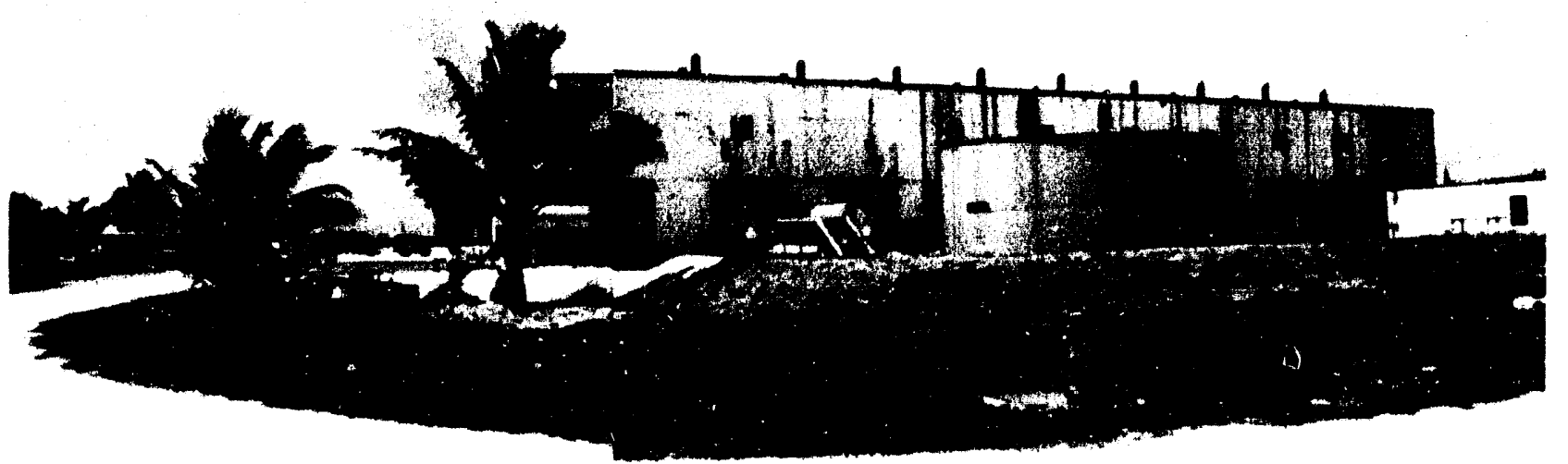

Fig. 3.4. Photograph of the diesel fuel storage tank on Kwajalein Island (ORNL DWG 6633-91). 
Table 3.1. On-site analyses of samples collected on Kwajalein Island during February 1991

Parameter

General procedure/field method

Soil

Water content

$\mathrm{pH}$

$\mathrm{NO}_{3}-\mathrm{N}, \mathrm{PO}_{4}-\mathrm{P}$

Oven drying at $105^{\circ} \mathrm{C}$, gravimetric analysis

Saturated paste, vacuum extraction, electrometric analysis

Saturated paste, vacuum extraction, colorimetric analysis

Aromatic hydrocarbons

TPH

Freon extraction, Friedel-Crafts acylation test kit analysis

Freon extraction, infrared spectroscopy analysis a

Water

Temperature

Conductance

$\mathrm{pH}$

Dissolved oxygen

Aromatic hydrocarbons

TPH

Electrometric, thermometric analysis

Electrometric analysis

Electrometric analysis

Electrometric analysis

Friedel-Crafts acylation test kit analysis

Freon extraction, infrared spectroscopy analysis ${ }^{\mathrm{a}}$

a Similar to U.S. EPA method 418.1 (13). 
Table 3.2. Off-site analyses of samples collected on Kwajalein Island during February 1991 and transported to ORNL

\begin{tabular}{|c|c|c|c|}
\hline Media/parameter & Container & Preservation & $\begin{array}{l}\text { Reference/analytical } \\
\text { method }\end{array}$ \\
\hline $\begin{array}{l}\text { Soil } \\
\text { Particle size } \\
\text { pH } \\
\text { TKN, NH4-N, } \mathrm{NO}_{3}-\mathrm{N} \\
\mathrm{PO}_{4}-\mathrm{P} \\
\text { SO4-S } \\
\text { Organic carbon } \\
\text { Exchangeable cations }\end{array}$ & $\begin{array}{l}1 \text { L polybag } \\
" \\
" \\
" \\
" \\
"\end{array}$ & $\begin{array}{l}4^{\circ} \mathrm{C} \\
" \\
" \\
" \\
" \\
"\end{array}$ & $\begin{array}{l}\text { Methods of Soil Analysis (11) } \\
\text { " } \\
\text { " } \\
\text { " } \\
\text { " }\end{array}$ \\
\hline $\begin{array}{l}\text { VOCs } \\
\text { SVOCs } \\
\text { TPH } \\
\text { Heavy metals } \\
\text { (Pb, Cu, Cr, Hg) } \\
\text { Total plate count }\end{array}$ & $\begin{array}{l}2,40 \mathrm{~mL} \text { glass } \\
125 \mathrm{~mL} \text { glass } \\
\text { " } \\
125 \mathrm{~mL} \text { glass } \\
\text { sterile glass or } \\
\text { plastic }\end{array}$ & $\begin{array}{l}4^{\circ} \mathrm{C} \\
4^{\circ} \mathrm{C} \\
4^{\circ} \mathrm{C} \\
4^{\circ} \mathrm{C}\end{array}$ & $\begin{array}{l}\text { SW5030/8240 (13) } \\
\text { SW3550/8270 (13) } \\
\text { Califomia method w/ } \\
\text { capillary column (13) } \\
\text { SW3050/7191/7210/7421 } \\
7471 \text { (13) } \\
\text { DOE Subsurface Microbiology Program } \\
\text { methods (12) }\end{array}$ \\
\hline $\begin{array}{l}\text { Water } \\
\text { Alkalinity } \\
\text { TDS } \\
\text { PO4-P } \\
\text { SO4-S } \\
\text { COD } \\
\text { TOC } \\
\text { TKN, NH4-N, } \\
\text { NO3-N }\end{array}$ & $\begin{array}{l}1 \text { L poly } \\
" \\
" \\
" \\
"\end{array}$ & $\begin{array}{l}4^{\circ} \mathrm{C} \\
" \\
" \\
" \\
" \\
"\end{array}$ & $\begin{array}{l}\text { APHA Standard Methods (10) } \\
\text { " } \\
\text { " } \\
\text { " } \\
\text { " }\end{array}$ \\
\hline $\begin{array}{l}\text { VOCs } \\
\text { SVOCs } \\
\text { Heavy metals } \\
(\mathrm{Pb}, \mathrm{Cu}, \mathrm{Cr}, \mathrm{Hg})\end{array}$ & $\begin{array}{l}2,40 \mathrm{~mL} \text { glass } \\
2,40 \mathrm{~mL} \text { glass } \\
0.5 \mathrm{~L} \text { poly }\end{array}$ & $\begin{array}{l}4^{\circ} \mathrm{C} \\
4^{\circ} \mathrm{C} \\
4^{\circ} \mathrm{C}\end{array}$ & $\begin{array}{l}\text { SW5030/8240 (13) } \\
\text { SW3550/8270 (13) } \\
\text { SW3020/7191/7210/7421/7471(13) }\end{array}$ \\
\hline
\end{tabular}


SECTION 4

RESULTS AND DISCUSSION

\subsection{SITE PHYSICAL CHARACTERISTICS}

\subsubsection{Landscape and Topography}

The landscape in the vicinity of the study area included various buildings associated with a diesel-fueled power plant (Fig. 3.1 to 3.4). The topography was level throughout the study area.

\subsubsection{Generalized Subsurface Conditions}

Island chains of the Pacific form over "hot spots" in the ocean crust. Submarine volcanoes form over these hot spots as lava flows into the sea. Each volcano eventually rises above sea level to become a volcanic island. In time, the movement of the tectonic plate on which the island rides causes the volcano to move off the hot spot. The volcano dies; however, a new volcano forms at some distance corresponding to the movement of the plate.

The Pacific tectonic plate is moving northwest, leaving chains of islands along a northwestsoutheast line. The dead volcanoes or seamounts at the southeast end of the chain are the youngest. The Marshall islands are an excellent example of this process. The ancient hot spot that formed the Marshalls either died or was passed over to take part in creation of the Gilbert Islands.

A dead volcsno or seamount begins to sink through the relatively thin oceanic crust because of its own mass at the same time erosion is eating at its shoreline, causing a shallow sloping shore. A coral reef then forms in the shallows. As the volcano continues to sink, the reef grows to form a fringing reef and eventually a barrier reef around the island. In time the island sinks below sea level, leaving only the reef to mark its former outline and a large lagoon within the reef.

In addition to the above processes, changes in sea level caused by tectonic events or the ice ages affect the formation of islands. If the sea level rises and the coral reef drops below the photic zone, the coral polyps die and the reef stops growing. If the sea level drops, portions of the reef may be exposed to additional erosional forces.

When the climate is in a relatively steady state, the reef remains near the surface. Islands are formed and maintained by wave action eroding portions of the sea floor and reef. The eroded material is then deposited behind the reef which forms the island. Storms and wind may deposit additional material to the islands. Hovever, the matrix of the island is primarily coral debris.

The geology of Kwajalein Island consists of heterogeneous coral sands and gravel at the surface ranging from 8 to $12 \mathrm{~m}$ in thickness. Lithology is typical of old reef channels, coral rubble piles, and fill. At the base of the sands and gravel is an unconformity typically marked by the occurrence of a hard coral ledge and perhaps conglomerate horizons. However, the hard coral and conglomerates that typically mark this unconformity are not present everywhere on the island [2]. This unconformity also seems to characterize the boundary between the freshwater surface lens and the more saline formation water, with the increase in salinity being described as abrupt at this interface [2]. 
The freshwater surface lens found on Kwajalein island is typical of coral atolls and can be described by the Ghyben-Herzberg relation [14]. This concept, developed around the turn of the century, has been modified over the years as more information has become available on surficial aquifers. In its more contemporary form, the Ghyben-Herzberg relation allows for mixing salt water and fresh water in a zone of diffusion around the interface between the two.

\subsubsection{Soil and Geology}

\subsubsection{Morphology}

Three test pits (TP1, TP2, TP3) were excavated in the desalination plant construction area, the deepest to $190 \mathrm{~cm}$ (Fig. 3.1). Lithologic logs of the test pit walls indicate that this area is probably fill (Appendix A). The matrix is moderately sorted, fine to medium grained, light tan coral sand with scattered to abundant pebble and cobble size pieces of coral. Optical enhancement showed that even the finest grains were coral reef debris. The first $25 \mathrm{~cm}$ in each pit contained pebble size coral pieces; in TP2 and TP3 the pieces increased to cobble size. Organics in the form of fine roots were visible to depths of 15 to $25 \mathrm{~cm}$. No fuel odors were noted for the subsurface soil exposed within these test pits.

The lithology of TP1 was consistent to its total depth. The top $15 \mathrm{~cm}$ of TP2 was a gray, moderately sorted, fine to medium grained coral sand, with light tan and dark gray sand stringers intermixed. In TP3, this gray sand showed up from 23 to $28 \mathrm{~cm}$ and 36 to $41 \mathrm{~cm}$. Gray coral boulders were observed in the stone revetment adjacent to the lagoon. The gray sands in these pits might be fill derived from these boulders, or from a different area of the island.

Test pits at the diesel fuel tank area (TP4, TP5, TP6) were excavated at the locations shown in Fig. 3.3. The lithologic log of TP4 was detailed, TP5 was logged from the surface because of safety concerns, and TP6 was not logged because of time and safety constraints.

TP4 was in a grassy area adjacent to and just outside of a bernı surrounding a diesel fuel tank. The $\log$ indicates that this area is probably fill from the mix of sands, pebbles, and cobbles. The top $5 \mathrm{~cm}$ was dark gray silt, probably breakdown fiom the grass, added soil, and possible nutrients. The next $41 \mathrm{~cm}$ was gray and tan coral sand, followed by tan sands to a total depth of $173 \mathrm{~cm}$. All levels contained abundant pebble and cobble size pieces of coral. Organic material was abundant to $20 \mathrm{~cm}$ with fine roots continuing to $46 \mathrm{~cm}$.

\subsubsection{Soil Characteristics}

On-site Soil Analyses: Analytical results for the saturation extracts are presented in Table 4.1.

The moisture content of the near-surface samples was typically slightly under $10 \%$ by weight (Table 4.1). Moisture content increased with depth, with values near $20 \%$ for the samples just above the water table and in an intermediate range for samples collected midway in the pit.

The $\mathrm{pH}$ of the soil sample extracts was alkaline, ranging from 7.4 to 8.5 . Alkaline $\mathrm{pH}$ is typical for coral-derived material, and the range in values was due to differences in the material matrix. Although all of the samples were coarse-grained, there were significant differences in the nature of some of the samples. Some of the soil samples were mostly sand-sized particles, while some contained abundant shell and coral fragments. 
Specific conductance of the saturation extracts revealed higher conductivities in the shallow soil material in the desalination site than that by the diesel tank site. The results demonstrated that the salinity in these soils is moderate and the shallow groundwater is not affected by marine influences.

Noric of the test pit soil samples contained nitrate. Because of heavy rainfall and subsequent leaching, the low nitrate concerttrations in the fill were expected. The only samples with a positive nitrate reading were composites prepared for use in respirometry experiments. These samples were analyzed in duplicate because the results were anomalous. The reanalysis compared very well to the first in toth cases. The reason for these results is unknown.

Soil phosphate results were highly variable. Several samples showed no detectable phosphate, and others showed part-per-million (ppm) levels The most likely explanation is that a particular type of shell or coral fragment was responsible for the phosphate in the extract and that the variations are because of the heterogeneity of the samples.

One soil sample from TP1 was analyzed for potassium; none was detected. This result is consistent with the information presented in the water analysis section in which the low availability of potassium in the subsurface is described.

Off-site Soil Analyses: The results of analyses conducted at ORNL are summarized in Tables 4.2 to 4.5 .

The soil materials had a considerable coarse fragment content, 20 to $45 \%$ by weight (Table 4.2). The fine soil matrix (i.e., $<2 \mathrm{~mm}$ ) was characterized as a loamy sand. Water contents ranged from $8 \%$ near the surface to saturated at the water table (Table 4.3). The soil pH measured in a distilled water extract was alkaline at 9.1 to 9.6 (Table 4.3). This range was higher than determined on-site.

Nitrogen (organic and/or ammonium) was present in some zones at levels of 0.01 to $0.02 \%$ by weight. There was, however, no readily extractable N, P, or S (Table 4.4). The predominant exchangeable cation was calcium, which is as expected for carbonate materials like coral sands (Table 4.5).

\subsubsection{Groundwater}

\subsubsection{Groundwater Depth}

The depths to groundwater in TP1, TP2, and TP3 were 157,160 , and $188 \mathrm{~cm}$, respectively. These correspond roughly to sea level in Kwajalein Lagoon, 24 to $46 \mathrm{~m}$ northwest of these test pits. Similar water levels were measured in the test pits in the vicinity of the diesel fuel tank site. The water level was $132 \mathrm{~cm}$ in TP4, $183 \mathrm{crn}$ in TP5, and $168 \mathrm{~cm}$ in TP6.

\subsubsection{Groundwater Composition}

On-site Groundwater Analyses: Results of on-site analyses of groundwater samples are summarized in Table 4.6. As shown, $\mathrm{pH}$ in the test pits was slightly alkaline and varied from 7.1 to 7.9. The conductivity for groundwater samples from all the tes: pits demonstrates that the water table is not markedly affected by seawater. Indeed, if the groundwater were used for 
irrigation water, these conductivity values would represent a low to medium salinity hazard $[15]$.

Alkalinity results are presented in $\mathrm{mg}-\mathrm{HCO}_{3} / \mathrm{L}$. The results vary within a relatively narrow range except for TP5 where the alkalinity was nearly double that measured for the other test pits.

Results of analyses for nitrate demonstrate relatively low levels of this nutrient. Low levels of nitrate are expected, based on the high rainfall and low organic matter content of the subsurface. Since the nutrient solution used to standardize the spectrophotometer was derived from hydrated solid material. Hence, the reported results may be biased low.

Phosphate was present in water from TP2 but was absent in groundwater samples from the other test pits.

Off-site Groundwater Analyses: The results of groundwater analyses conducted at ORNL are summarized in Tables 4.7 to 4.9.

The groundwater was somewhat alkaline with a $\mathrm{pH}$ of 7.9 to 8.2. There was no marked marine influence as evidenced by low chloride contents (Table 4.7). There were trace levels of nutrients in some samples. In groundwater at the location of TP4, considerable chemical oxygen demand (COD) and total organic carbon (TOC) were found in the groundwater (Table 4.8). This finding is presumed to be due to the diesel fuel contamination (discussed below). The dominant cations in the groundwater were calcium, magnesium, and sodium (Table 4.9).

\subsection{SITE CONTAMINATION CHARACTERISTICS}

\subsubsection{Diesel Fuel Characteristics}

The results of volatile and semivolatile organic analyses of the diesel fuel from USAKA are summarized in Table 4.10. There were no detectable concentrations of VOCs, but low concentrations of a variety of SVOCs were identified including napthalenes, phenanthrene, and other substituted aliphatic and aromatic compounds. As expected, the concentrations of gas chromatographable VOCS and SVOCs in the USAKA diesel fuel were low. Diesel fuel is typically composed of $30 \%$ substituted aromatic hydrocarbons and $70 \%$ long-chain aliphatic hydrocarbons [16].

\subsubsection{Soil Contamination}

\subsubsection{On-site Soil Contaminant Analyses}

The results of on-site analyses of soil samples by extraction and infrared (IR) spectrophotometry are summarized in Tables 4.11 and 4.12. Low levels of TPH were detected in the surface soil at TP1. A trace of aromatic hydrocarbons was also present based on the Friedel-Crafts acylation (FCA) test kit. TP1 is near an industrialized area with frequent vehicle traffic. Such an analytic result, therefore, is not believed to be indicative of widespread contamination. The low result also demonstrates that contamination near TP1 is not significant. This conclusion was confirmed by off-site analyses described below, which revealed traces of polyaromatic hydrocarbons frequently found in surface soils adjacent to 
roads [17].

IR analysis indicated that no contamination was present in TP2. These results were consistent with the FCA and photoionization detector (PID) results demonstrating that the area near TP2 is not contaminated.

Soil contamination analyses for samples from TP3 were not straightforward. Significant concentrations of hydrocarbons were detected by IR for the sample collected at 39 in., with a much lower concentration at 12-in. Hydrocarbons were not detected in the soil sample collected near the water table although hydrocarbons were detected in the water sample. The FCA results for these same samples showed trace levels in the 12-in. soil sample and nothing detected in the 39- and 72-in. soil samples. These results in conjunction with the IR suggest that whatever was detected by the IR was not fuel. This judgment is based on the fact that it would be unlikely, though not impossible, for significant fuel to be in the sample with no aromatic hydrocarbons present. The area in the vicinity of TP3 is not vegetated. Consequently, natural organic matter is unlikely. This location is near a paint shed, and it is possible that nonvolatile paint components were present.

Results for the other test pits were consistent with the results from other test methods, including visual observations. All samples from TP4 and TP5 were significantly contaminated while those from TP6 showed no contamination (Table 4.12). Results for some of the samples frora TP4 were quite high, suggesting the presence of discrete products and not simply oil sorbed onto coral particles. FCA results for TP4 tend to be lower than the IR results. This difference may be because the FCA responds only to aromatic hydrocarbons and not to all hydrocarbons as the IR does.

A conclusion that can be drawn from these data is that the FCA results are consistent with the IR when the contaminants are fuel-based hydrocarbons. This conclusion is also based on a comparison of data from samples collected at Roi-Namur that will be reported separately. Those results for fuel samples showed excellent correlation between the IR and the FCA methods. Results are not consistent at TP3, suggesting again that whatever was detected by the $\mathbb{R}$ is probably not due to fuel, unless it is highly weathered.

\subsubsection{Off-site Soil Contaminant Analyses}

A complete listing of samples collected for off-site analyses may be found in Appendix B, while detailed analytical results are given in Appendix $C$ and $D$. The summarized results of these analyses are presented in Tables 4.13 to 4.21 .

The desalination plant site was found to contain only low levels of TPH and only in TP3 (Table 4.13). TPH concentrations in TP 3 were $\leq 5 \mathrm{ppm}$ and were judged to be jet fuel, based on chromatographic characteristics. Low levels of SVOCs $(<5 \mathrm{ppm})$ were determined in the shallow soil (8-in. depth) (Table 4.15). Trace concentrations (i.e., $<53 \mathrm{ppb}$ ) of a few VOCs (e.g., chloroform and 1,1,1-trichloroethane) were measured in soil samples from TP2 and TP3 (Table 4.17). These VOCs are common components in organic solvents and are not surprising when found at a site where painting activities occur. At the desalination plant site, there were no detectable or marked concentrations of heavy metals or radioactive substances (Tables 4.19 and 4.21).

At the diesel fuel tank site, TPH concentrations were nearly $9000 \mathrm{mg} / \mathrm{kg}$ at the water table in TP4 (Table 4.14). There were only trace levels of a few SVOCs and VOCs (Tables 4.16 to 4.18). There were no notable heavy metals or radiochemicals (Tables 4.20 and 4.21 ). 


\subsubsection{Groundwater}

\subsubsection{On-site Groundwater Contaminant Analyses}

Results of on-site analyses of groundwater samples for hydrocarbons by extraction and infrared spectrophotometry are summarized in Table 4.11 and 4.12.

Of the three test pits at the desalinization site, only TP3 showed detectable hydrocarbons by IR. Because infrared analysis indicates only the presence of carbon-hydrogen bonds, it is difficult to interpret these results, considering that both field screening with a PID and the FCA indicated no detectable contamination. It is possible that relatively nonvolatile contaminants are present. TP3 was in a heavily-used area within a few feet of a paint shed. The surface of the ground was discolored in some areas, and it was evident that some of the drums and paint buckets had leaked or been spilled in the area. A sample of water from TP3 submitted to the off-site analytical laboratory indicated no contamination, although the overlying soil contained traces of jet fuel hydrocarbons.

The IR results for water samples from TP4, TP5, and TP6 were consistent with visual observations and FCA test kit results. TP4 and TP5 contained significant contamination while TP6 was uncontaminated.

Groundwater collected from a monitoring well installed in a previous program by the U. S. Geological Survey (USGS) was also analyzed by the IR method. Monitoring well 17 was northeast of the desalinization site in an area suspected of being contaminated. The IR results revealed some contamination with petroleum hydrocarbons (Table 4.12).

Two liquid samples were collected from the sewerage system yielding the IR results shown in Table 4.12. These samples were collected in the vicinity of the desalination plant and diesel fuel tank site. The results suggest potential contamination with petroleum hydrocarbons.

The results of the FCA indicated that only the obviously contaminated water samples (i.e., TP4 and TP5) were indeed contaminated. The sensitivity of the test kit, however, could be improved dramatically by employing glassware appropriate for performing extractions that concentrate the sample.

\subsubsection{Off-site Groundwater Contaminant Analyses}

A complete listing of samples collected for off-site analyses may be found in Appendix B, while detailed analytical results are given in Appendix $C$ and $D$. The summarized results of off-site analyses for groundwater contaminants are presented in Tables 4.13 to 4.21 .

TPH and SVOCs were not detected in groundwater samples collected from TP1 to TP3 at Ithe desalination plant site (Tables 4.13 and 4.15). Trace concentrations (i.e., parts-per-billion (ppb) and very much less than drinking water standards) of the VOCs, chloroform and 1,1,1trichloroethane were detected in the shallow groundwater beneath TP2 and TP3 (Table 4.17). These VOCs are commonly found in solvents, such as those used in the painting operation currently located on the desalination plant construction site, and were present in the unsaturated soils in TP2 and TP3. Detection of trace levels in the groundwater could have been due to some unavoidable soil disturbance which occurred during the test pit groundwater sampling procedures.

Significant contamination by organic substances was determined for the diesel fuel tank site. High concentrations of COD $(220 \mathrm{mg} / \mathrm{L})$ and TOC $(40 \mathrm{mg} / \mathrm{L})$ were in groundwater from TP4 
(Table 4.7). TPH was measured at $265 \mathrm{mg} / \mathrm{L}$ in TP4 and $110 \mathrm{mg} / \mathrm{L}$ in TP5 (Table 4.14). This groundwater contamination is consistent with the high concentrations of petroleum hydrocarbons measured in the overlying soil materials.

At both study sites, concentrations of heavy metals were either nondetectable or at very low levels (i.e., ppb), which could be interpreted as similar to natural conditions (Tables 4.19 and 4.20).

Radiochemical screening of the groundwater samples from TP3 at the desalination plant site and TP4 at the diesel fuel tank site revealed no contamination by radioactive substances (Table 4.21)

\subsection{ON-SITE BIOTREATABILITY STUDIES}

\subsubsection{Microbiology and Microcosm Experiments}

Microbiological analyses demonstrated that microorganisms were present in the subsurface on $\mathrm{K}$ wajalein Island in appreciable numbers (e.g., $10^{5}$ to $10^{7} \mathrm{org} / \mathrm{g}$ ) in all areas examined (Table 4.22). These included both uncontaminated (i.e., TP1 to TP3) and contaminated zones (i.e., TP4, TP5).

There were some trends in the microbiology data. Within the shallow soil (e.g., 10 to 12 in. in depth), the colony forming unit (CFU) concentrations were typical of surface soils. Below this depth, CFU concentrations decreased. In the most contaminated zones below $1.5 \mathrm{~m}(60 \mathrm{in}$.) in TP4 and TP5, the relatively lower numbers $\left(<10^{5} \mathrm{org} / \mathrm{g}\right)$ may be due to toxicity effects caused by high hydrocarbon contamination. Also, the relatively higher CFU concentrations determined in the laboratory as compared to the field assays may likely represent growth after sample collection.

The results of the microcosm experiments are summarized in Table 4.23. Enrichment tubes without fuel agreed with the CFU plate counts and indicated microorganism concentrations at $>10^{3} \mathrm{org} / \mathrm{g}$. Most enrichment broth samples exhibited turbidity on fuel at the $2-\mathrm{g} / \mathrm{tube}$ level. Soil samples from TP1 at $20 \mathrm{~cm}$ (8 in.) in depth exhibited petroleum degradation at a dilution of $10^{3} / \mathrm{g}$, while other TP1 samples exhibited petroleum degradation only at $2 \mathrm{~g} /$ tube. Samples from TP2 and TP 3 exhibited little ability to attack diesel fuel. In contrast, samples from TP4 and TP5 showed ability to attack diesel fuel in fresh or brackish media at pH 7.4 or 8.5 as well as in mineral salt media at $10^{3}$ dilutions. The headspace in several of these tubes exhibiting high growth were analyzed by field gas chromatography. Several samples demonstrated loss of benzene or toluene. For example, an enrichment sample from TP4 at 10 in. in depth indicated the following contaminant losses during incubation: $66 \%$ benzene, $95 \%$ toluene, and $70 \%$ xylenes. Another sample from TP4 at the same depth exhibited losses of $>95 \%$. Enrichments from construction zone test pits 2 and 3 also exhibited the ability to degrade petroleum compounds.

\subsubsection{Soil Respiration Experiments}

Results of the soil respiiation experiments are summarized in Table 4.24. Soil materials from an uncontaminated area (i.e., TP1) in the desalination plant site exhibited no oxygen uptake when incubated for several days. 
The addition of fresh diesel fuel and/or nutrients had no measurable effect. In contrast, soil materials from a contaminated area (i.e., TP4 and TP5) exhibited noticeable oxygen uptake, but only when fresh fuel was added (concentration of $5000 \mathrm{mg} / \mathrm{kg}$ ).

The respiration data suggested that the microbes indigenous to the uncontaminated areas were not adapted or readily capable of degrading fresh diesel fuel. Also, for the contaminated soil samples, the indigenous microbes were not respiring at high rates on the ambient or weathered diesel fuel contamination. Only when fresh diesel fuel was added did the respiration rates markedly increase. This suggests that the ambient or weathered diesel fuel may not be readily biodegradable under ambient conditions. 
Table 4.1 On-site analyses of saturated soil extracts from soil samples collected on Kwajalein Island during February 1991

\begin{tabular}{|c|c|c|c|c|c|}
\hline Test pit $a$ and depth & Water content & $\mathrm{pH}$ & $\begin{array}{c}\text { Specific } \\
\text { conductance }\end{array}$ & $\mathrm{NO}_{3}-\mathrm{N}$ & $\mathrm{PO}_{4}-\mathrm{P}$ \\
\hline & dry wt \% & & umhos/cm & ppm & $\mathrm{ppm}$ \\
\hline$\frac{\text { Test pit TP1 }}{\text { Soil at } 08 \text { in. }}$ & 7.3 & 7.4 & 1200 & 0 & 3 \\
\hline Soil at 33 in. & $\begin{array}{r}14.7 \\
{[17.4]^{b}}\end{array}$ & 8.16 & 1320 & 0 & 10 \\
\hline Soil at 56 in. & 25.3 & 8.23 & 525 & 0 & 2.75 \\
\hline Soil composite $c$ & 16.9 & 7.82 & - & $\begin{array}{r}7 \\
\{6\}^{d}\end{array}$ & 6.75 \\
\hline$\frac{\text { Test pit TP2 }}{\text { Soil at } 06 \text { in. }}$ & 9.6 & 8.4 & 600 & 0 & 3.5 \\
\hline Soil at 33 in. & 14.7 & 8.47 & 540 & 0 & 0 \\
\hline Soil at 63 in. & 27.2 & 8.28 & 150 & 0 & 30 \\
\hline$\frac{\text { Test pit TP3 }}{\text { Soil at } 12 \text { in. }}$ & 12.2 & 7.79 & 880 & 0 & 0 \\
\hline Soil at 39 in. & 12.6 & 8.32 & 1090 & 0 & 19.75 \\
\hline Soil at 72 in. & 36.8 & 8.03 & 860 & 0 & 0 \\
\hline$\frac{\text { Test pit TP4 }}{\text { Soil at } 10 \mathrm{in} .}$ & 8.2 & 8.1 & 309 & 0 & 11 \\
\hline Soil at 32 in. & 25.6 & 8.2 & 370 & 0 & 12.9 \\
\hline Soil at $63 \mathrm{in.}$ & 27.2 & 8.04 & 470 & 0 & 4.75 \\
\hline Soil composite $\mathrm{c}$ & 26.9 & $\begin{array}{r}8.02 \\
\{8.18\}\end{array}$ & $\begin{array}{r}500 \\
\{370\}\end{array}$ & $\begin{array}{r}5 \\
\{7\}\end{array}$ & $\begin{array}{r}13.5 \\
\{3.3\}\end{array}$ \\
\hline$\frac{\text { Test pit TP5 }}{\text { Soil at } 62 \text { in. }}$ & 35.1 & 7.91 & 720 & 0 & 0 \\
\hline \multicolumn{6}{|l|}{ Test pit TP6 } \\
\hline Soil at 63 in. & 44.7 & 8.36 & 450 & 0 & 6 \\
\hline $\begin{array}{l}\text { a Refer to Fig. } 3.1 \text { to } \\
\text { b [ ] Indicates analys } \\
\text { c Composites were } \\
\text { d \{ \} Indicates analys }\end{array}$ & $\begin{array}{l}\text { for test pit loc: } \\
\text { twice from sa } \\
\text { by mixing fielc } \\
n \text { in duplicate }\end{array}$ & $\begin{array}{l}\text { s. } 1 \text { in. } \\
\text { xtract. } \\
\text { st soil f } \\
\text { o separa }\end{array}$ & $\begin{array}{l}\text { ach of the thr } \\
\text { racts. }\end{array}$ & depths. & \\
\hline
\end{tabular}


Table 4.2. Physical characteristics of soil samples collected on Kwajalein

Island during February 1991

\begin{tabular}{|c|c|c|c|c|c|}
\hline \multirow[b]{2}{*}{ Test pit $\mathbf{a}$ and depth } & \multirow[b]{2}{*}{$\begin{array}{c}\text { Coarse } \\
\text { fragments } \\
>2.0 \mathrm{~mm}\end{array}$} & \multicolumn{2}{|c|}{ Sand } & \multirow{2}{*}{$\begin{array}{c}\text { Silt } \\
0.002- \\
0.045 \mathrm{~mm}\end{array}$} & \multirow{2}{*}{$\begin{array}{l}\text { Clay } \\
<\underset{\text { mm }}{0.002}\end{array}$} \\
\hline & & $\begin{array}{c}\text { Coarse } \\
0.5- \\
2.0 \mathrm{~mm}\end{array}$ & $\begin{array}{c}\text { Fine } \\
0.045- \\
0.5 \mathrm{~mm}\end{array}$ & & \\
\hline
\end{tabular}

Test pit TP1

Soil at 08 in.

24

24

35

14.6

2.4

Soil at 33 in.

27

26

34

11.6

1.4

Soil at 56 in.

23

19.7

43.3

13.0

1.0

\section{Test pit TP3}

Soil at 12 in.

21

20

38

17.1

3.9

Soil at 39 in.

24.5

24.6

48.2

2.6

0.1

Soil at 72 in.

45.5

29.5

25.0

0

0

Test pit TP4

Soil at 10 in.

20

35

38

5.6

0.4

Soil at 32 in.

21

38

40

1.0

0.0

Soil at 65 in.

3

23

74

0

0

a Refer to Fig. 3.1 to 3.4 for test pit locations. Analyses conducted in ORNL laboratories. Sand analyses by wet sieving, and silt and clay by hydrometer. 1 in. $=2.54 \mathrm{~cm}$. 
Table 4.3. Basic physical/chemical properties of soil samples collected on Kwajalein Island during February 1991

\begin{tabular}{llrl}
\hline Test pit a and depth & USDA Texture $b$ & Water content & pH \\
\hline Test pit TP1 & & dry wt \% & \\
Soil at 08 in. & loamy sand & 8.0 & 9.29 \\
Soil at 33 in. & loamy sand & 11.6 & 9.55 \\
Soil at 56 in. & loamy sand & 17.0 & 9.29 \\
\hline
\end{tabular}

Test pit TP3

Soil at 12 in.

loamy sand

9.2

9.37

Soil at 39 in.

sand

13.0

9.42

Soil at 72 in.

sand

22.4

9.34

Test pit TP4

Soil at $10 \mathrm{in.}$

sand

11.0

9.24

Soil at 32 in.

sand

19.0

9.55

Soil at 65 in.

sand

28.2

9.16

a Refer to Fig. 3.1 to 3.4 for test pit locations. Analyses conducted in ORNL laboratories. 1 in. $=2.54 \mathrm{~cm}$.

b Based on fine earth fraction (i.e., $<2.0 \mathrm{~mm}$ diameter particles). 
Table 4.4. Nutrient content in soil samples collected on Kwajalein Island during February 1991

\begin{tabular}{|c|c|c|c|c|}
\hline Test pit ${ }^{a}$ and depth & TKN & $\mathrm{NO}_{3}-\mathrm{N}^{\mathrm{b}}$ & $\mathrm{PO}_{4}-\mathrm{Pb}$ & $\mathrm{SO}_{4}-\mathrm{S} \mathrm{b}^{\mathrm{b}}$ \\
\hline & $\mathrm{mg}-\mathrm{N} / \mathrm{kg}$ & $\mathrm{mg}-\mathrm{N} / \mathrm{L}$ & $\mathrm{mg}-\mathrm{P} / \mathrm{L}$ & $\mathrm{mg}-\mathrm{S} / \mathrm{kg}$ \\
\hline \multicolumn{5}{|l|}{ Test pit TP1 } \\
\hline Soil at 08 in. & 190 & $<0.1 \mathrm{c}$ & $<0.1$ & 0.1 \\
\hline Soil at 33 in. & 90 & $<0.1$ & $<0.1$ & $<0.1$ \\
\hline Soil at 56 in. & 110 & $<0.1$ & $<0.1$ & $<0.1$ \\
\hline \multicolumn{5}{|l|}{ Test pit TP3 } \\
\hline Soil at $12 \mathrm{in.}$ & 160 & $<0.1$ & $<0.1$ & $<0.1$ \\
\hline Soil at $39 \mathrm{in.}$ & 130 & $<0.1$ & $<0.1$ & $<0.1$ \\
\hline Soil at 72 in. & 110 & $<0.1$ & $<0.1$ & 0.1 \\
\hline \multicolumn{5}{|l|}{ Test pit TP4 } \\
\hline Soil at $10 \mathrm{in.}$ & 220 & $<0.1$ & $<0.1$ & $<0.1$ \\
\hline Soil at 32 in. & 280 & $<0.1$ & $<0.1$ & $<0.1$ \\
\hline Soil at 65 in. & 150 & $<0.1$ & $<0.1$ & $<0.1$ \\
\hline
\end{tabular}

a Refer to Fig. 3.1 to 3.4 for test pit locations. Analyses conducted in ORNL laboratories. 1 in. $=2.54 \mathrm{~cm}$.

b Analyses for N, P, and S were conducted on carbonate/bicarbonate extract of soil (20-g/L ratio).

c < Indicates substance not detected at detection limit shown. 
Table 4.5. Exchangea' e cation content in soil samples collected on Kwajalein Island during February 1991

\begin{tabular}{lccccccccc}
\hline Test pit a and depth & $\mathrm{Ba}$ & $\mathrm{Ca}$ & $\mathrm{Fe}$ & $\mathrm{K}$ & $\mathrm{Mg}$ & $\mathrm{Mn}$ & $\mathrm{Mo}$ & $\mathrm{Na}$ & $\mathrm{Zn}$ \\
\hline & $\mathrm{mg} / \mathrm{L}$ & $\mathrm{mg} / \mathrm{L}$ & $\mathrm{mg} / \mathrm{L}$ & $\mathrm{mg} / \mathrm{L}$ & $\mathrm{mg} / \mathrm{L}$ & $\mathrm{mg} / \mathrm{L}$ & $\mathrm{mg} / \mathrm{L}$ & $\mathrm{mg} / \mathrm{L}$ & $\mathrm{mg} / \mathrm{L}$ \\
Test pit TP1 & & & & & & & & & \\
Soil at 8 in. & $<0.3$ & 340 & $<0.2$ & 0.26 & 17 & $<0.004$ & $<0.16$ & 7.6 & 0.09 \\
Soil at 33 in. & $<0.3$ & 410 & $<0.2$ & 0.24 & 17 & 0.014 & $<0.16$ & 3.3 & 0.02 \\
Soil at 56 in. & $<0.3$ & 440 & $<0.2$ & 0.16 & 17 & 0.015 & $<0.16$ & 3.2 & $<0.02$ \\
\hline
\end{tabular}

\section{Test pit TP3}

$\begin{array}{llllllllll}\text { Soil at } 12 \text { in. } \quad<0.3 & 410 & <0.2 & 0.24 & 16 & 0.024 & <0.16 & 3.7 & 0.11\end{array}$

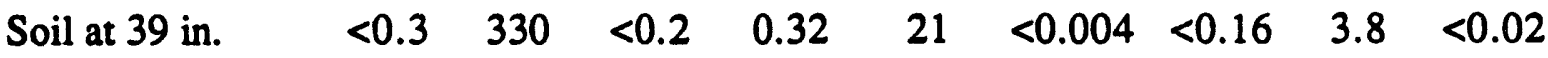

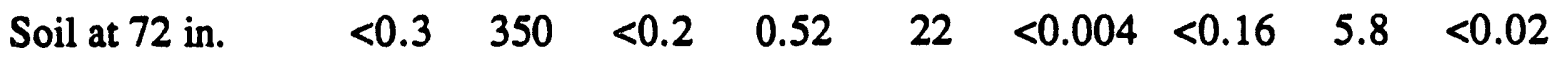

Test pit TP4

$\begin{array}{llllllllll}\text { Soil at } 10 \text { in. } \quad & <0.3 & 340 & <0.2 & 0.32 & 22 & 0.018 & <0.16 & 3.3 & 0.044\end{array}$

$\begin{array}{llllllllll}\text { Soil at } 32 \text { in. } \quad<0.3 & 370 & <0.2 & 0.28 & 19 & <0.004 & <0.16 & 3.1 & 0.027\end{array}$

$\begin{array}{llllllllll}\text { Soil at } 65 \text { in. } \quad<0.3 & 440 & <0.2 & 0.16 & 20 & <0.004 & <0.16 & 3.2 & 0.02\end{array}$

a Refer to Fig. 3.1 to 3.4 for test pit locations. Analyses conducted in ORNL laboratories on an ammonium acetate extract. 1 in. $=2.54 \mathrm{~cm}$.

$\mathrm{b}<$ Indicates cation not detected at detection limit shown. 
Table 4.6. On-site analyses for physical/chemical characteristics of groundwater samples collected on Kwajalein Island during February 1991

\begin{tabular}{|c|c|c|c|c|c|}
\hline Test pit a & $\mathrm{pH}$ & $\begin{array}{c}\text { Specific } \\
\text { conductance }\end{array}$ & Alkalinity & $\mathrm{NO}_{3}-\mathrm{N}$ & $\mathrm{PO}_{4}-\mathrm{P}$ \\
\hline & & umhos/cm & $\mathrm{mg}-\mathrm{HCO}_{3} / \mathrm{L}$ & ppm & ppm \\
\hline Test pit TP1 & 7.92 & 560 & 200 & 0.15 & $<0.6$ \\
\hline Test pit TP2 & 7.37 & 890 & 350 & $\begin{array}{r}0.65 \\
{[0.65]^{b}}\end{array}$ & 2.18 \\
\hline Test pit TP3 & 7.57 & 750 & 200 & 0.15 & $<0.6$ \\
\hline Test pit TP4 & 7.32 & 690 & 360 & ND & $<0.6$ \\
\hline Test pit TP5 & 7.15 & 1280 & 600 & $-c$ & - \\
\hline Test pit TP6 & 7.33 & 800 & - & - & - \\
\hline
\end{tabular}

a Refer to Fig. 3.1 to 3.4 for test pit locations. Groundwater samples were collected at the water table surface, and analyses were conducted on USAKA in a temporary laboratory.

b [ ] Indicates duplicate analysis.

c - Indicates analysis not run. 
Table 4.7. Basic physical/chemical properties of groundwater samples collected on Kwajalein Island during February 1991

\begin{tabular}{lccccc}
\hline Test pit a & $\mathrm{pH}$ & Alkalinity & Chloride & $\begin{array}{c}\text { Chemical } \\
\text { oxygen } \\
\text { demand }\end{array}$ & $\begin{array}{c}\text { Total } \\
\text { organic } \\
\text { carbon }\end{array}$ \\
\hline Test pit TP1 & - & $\mathrm{mg-CaCO} / \mathrm{L}$ & $\mathrm{mg} / \mathrm{L}$ & $\mathrm{mg} / \mathrm{L}$ & $\mathrm{mg} / \mathrm{L}$ \\
Test pit TP3 & 8.19 & 210 & 37 & 7 & 1.2 \\
& 8.21 & 214 & 61 & 10 & 2.1 \\
\hline Test pit TP4 & & & & & \\
& 7.93 & 325 & $-\mathrm{b}$ & 220 & 40.0 \\
\hline
\end{tabular}

a Refer to Fig. 3.1 to 3.4 for test pit locations. Groundwater samples were collected at the water table surface, and analyses were conducted in ORNL laboratories.

b - Indicates analysis not run. 
Table 4.8. Macronutrient content in groundwater samples collected on Kwajalein Island during February 1991

\begin{tabular}{lcccccc}
\hline Test pit a & $\mathrm{TKN}$ & $\mathrm{NH}_{4}-\mathrm{N}$ & $\mathrm{NO}_{3}-\mathrm{N}$ & $\mathrm{PO}_{4}-\mathrm{P}$ & $\mathrm{SO}_{4}-\mathrm{S}$ & $\mathrm{K}$ \\
\hline & $\mathrm{mg}-\mathrm{N} / \mathrm{L}$ & $\mathrm{mg}-\mathrm{N} / \mathrm{L}$ & $\mathrm{mg}-\mathrm{N} / \mathrm{L}$ & $\mathrm{mg}-\mathrm{P} / \mathrm{L}$ & $\mathrm{mg}-\mathrm{S} / \mathrm{L}$ & $\mathrm{mg}-\mathrm{K} / \mathrm{L}$ \\
Test pit TP1 & $<0.2$ & 0.32 & $<1$ & $<1$ & 14 & 1.1 \\
Test pit TP3 & $<0.2$ & 0.21 & 8.5 & $<1$ & 75 & 4.7 \\
\hline Test pit TP4 & & & & & & \\
\hline
\end{tabular}

a Refer to Fig. 3.1 to 3.4 for test pit locations. Groundwater samples were collected at the water table surface and analyses were conducted in ORNL laboratories.

b - Indicates analysis not run. 
Table 4.9. Elemental content in groundwater samples collected on Kwajalein Island during February 1991 a

\begin{tabular}{|c|c|c|c|c|c|c|c|c|c|c|}
\hline Test pit $b$ & $\mathrm{Ca}$ & $\mathrm{Mg}$ & $\mathrm{Na}$ & B & $\mathrm{Cu}$ & $\mathrm{Fe}$ & $\mathrm{Mn}$ & Mo & $\mathrm{Al}$ & $\mathrm{Zn}$ \\
\hline & $\mathrm{mg} / \mathrm{L}$ & $\mathrm{mg} / \mathrm{L}$ & $\mathrm{mg} / \mathrm{L}$ & ug/L & $\mathrm{ug} / \mathrm{L}$ & $\mathrm{ug} / \mathrm{L}$ & $\mathrm{ug} / \mathrm{L}$ & $\mathrm{ug} / \mathrm{L}$ & $\mathrm{ug} / \mathrm{L}$ & $\mathrm{ug} / \mathrm{L}$ \\
\hline Test pit TP1 & 58 & 33 & 21 & 0.011 & $<7^{c}$ & $<50$ & $<1$ & $<40$ & $<50$ & $<5$ \\
\hline Test pit TP3 & 38 & 43 & 65 & 0.18 & $<7$ & $<50$ & $<1$ & $<40$ & $<50$ & $<5$ \\
\hline Test pit TP4 & 110 & d & $<25$ & $<400$ & $<35$ & $<250$ & $<5$ & $<200$ & - & $<25$ \\
\hline
\end{tabular}

a Groundwater samples were collected at the water table surface, and analyses were conducted in ORNL laboratories.

b Refer to Fig. 3.1 to 3.4 for test pit locations.

c < Indicates element not detected at detection limit shown.

d - Indicates analysis not conducted. 
Table 4.10. Concentrations of volatile and semivolatile organic compounds measured in a diesel fuel sample collected from the diesel fuel power plant

by ORNL in February 1991

Organic compound a

Concentration

Qualifier b

$\mathrm{ug} / \mathrm{L}$

Volatile Organics

34 Compounds analyzed for and none detected

nd

\section{Semivolatile Organics}

65 Compounds analyzed for, plus 20 unidentified peaks

Consounds detected include:

napthalene

2-methylnapthalene

phenanthrene

Tentatively identified compounds:

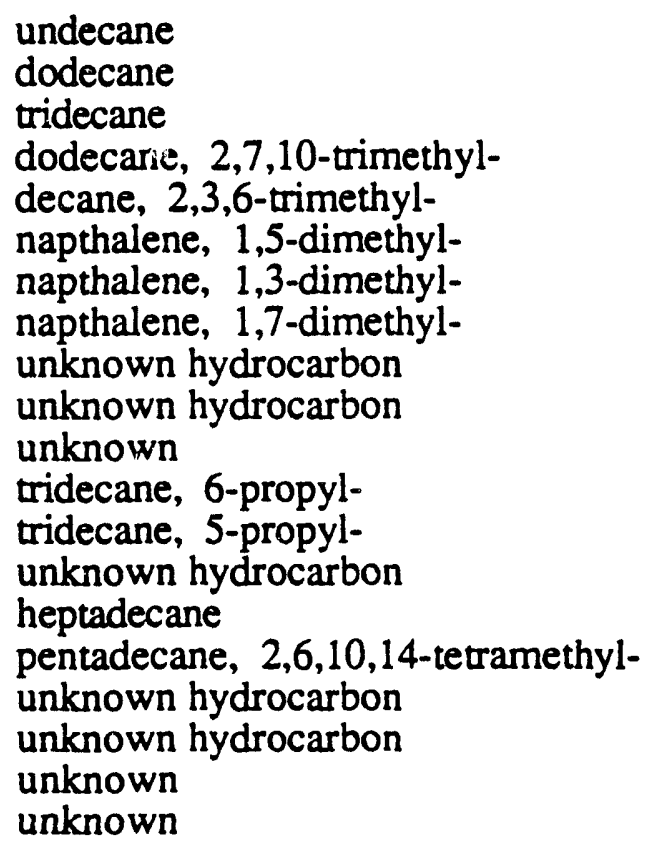

a Analysis made on a sample of fresh diesel fuel collected on Kwajalein Island. Analysis made in ORNL laboratories by gas chromatography-mass spectroscopy.

b $\mathrm{J}$ Indicates estimated value. 
Table 4.11. Field screening results for total hydrocarbons measured in soil and groundwater samples collected from the desalination plant site by ORNL in February 1991

Field screening analyses

Test pit a and sample depth

Friedel Crafts

acylation $^{b} \quad$ Infrared spectroscopy $c$

ppm

ppm

\section{Test pit TP1}

Soil at 08 in.

$$
x^{d}
$$

40

Soil at 33 in.

$\mathbf{x}$

$\mathbf{x}$

Soil at 56 in.

$\mathbf{x}$

$\mathbf{x}$

Groundwater at 56 in.

$\mathbf{x}$

$\mathbf{x}$

\section{Test pit TP2}

Soil at 06 in.

$\mathbf{x}$

$\mathbf{x}$

$\mathbf{x}$

Groundwater at 65 in. x $x$

$x$

$\mathbf{X}$

$\mathbf{x}$

$1470^{e}$

x $x$

$\mathrm{x}$

a Refer to Fig. 3.1 to 3.4 for test pit locations. 1 in. $=2.54 \mathrm{~cm}$.

b Friedel-Crafts acylation with a freon extraction of a soil sample and color chart comparison.

c Infrared analysis of a freon extraction of a soil sample.

$\mathrm{d} x$ Indicates hydrocarbons not detected (detection limit $=$ ca. $10 \mathrm{ppm}$ ).

e This high value appears to be an anomaly based on field observations and laboratory data. 
Table 4.12. Field screening results for total hydrocarbons measured in soil and groundwater samples collected from the diesel fuel tank site by ORNL in February 1991

\begin{tabular}{|c|c|c|}
\hline \multirow[b]{2}{*}{ Test pit ${ }^{a}$ and depth } & \multicolumn{2}{|c|}{ Field screening analyses } \\
\hline & $\begin{array}{l}\text { Friedel Crafts } \\
\text { acylation b }\end{array}$ & Infrared spectroscopy $c$ \\
\hline & ppm & ppm \\
\hline \multicolumn{3}{|l|}{ Test pit TP4 } \\
\hline Soil at $10 \mathrm{in.}$ & $1-10$ & $\begin{array}{r}235 \\
{[490]^{d}}\end{array}$ \\
\hline Soil at 32 in. & $x^{e}$ & $\begin{array}{r}1600 \\
{[350]}\end{array}$ \\
\hline Soil at 65 in. & $\mathbf{x}$ & $\begin{array}{r}4235 \\
{[4176]}\end{array}$ \\
\hline Groundwater at 65 in. & $500-2000$ & 1100 \\
\hline
\end{tabular}

\section{Test pit TP6}

Soil at 72 in

$\mathbf{x}$

Qther

Sewer manhole southeast of TP4

$\mathbf{x}$

$\mathbf{x}$

$\mathbf{x}$
3.5

2.9

17

\footnotetext{
${ }^{a}$ Refer to Fig. 3.1 to 3.4 for test pit locations. 1 in. $=2.54 \mathrm{~cm}$.

b Friedel-Crafts acylation with a freon extraction of a soil sample and color chart comparison.

c Infrared analysis of a freon extraction of a soil sample.

d [ ] Indicates duplicate analysis.

e $x$ Indicates hydrocarbons not detected (detection limit $=$ ca. $10 \mathrm{ppm}$ ).
} 
Table 4.13. Concentrations of total petroleum hydrocarbons measured in soil and groundwater samples collected from the desalination plant site

by ORNL in February 1991

\begin{tabular}{|c|c|c|}
\hline Test pit a and depth & $\begin{array}{l}\text { Total hydrocarbon } \\
\text { concentration } b\end{array}$ & $\begin{array}{c}\text { Substance similarity } \\
\text { based on chromatograph }\end{array}$ \\
\hline & ppm & \\
\hline \multicolumn{3}{|l|}{ Test pit TP1 } \\
\hline Soil at 08 in. & $<10^{c}$ & - \\
\hline Soil at 33 in. & $<10$ & - \\
\hline Soil at 56 in. & $<10$ & - \\
\hline Groundwater at 56 in. & $<10$ & - \\
\hline \multicolumn{3}{|l|}{ Test pit TP2 } \\
\hline Soil at 63 in. & $<10$ & - \\
\hline Groundwater at 65 in. & $<10$ & - \\
\hline \multicolumn{3}{|l|}{ Test pit TP3 } \\
\hline Soil at 12 in. & 5.0 & jet fuel \\
\hline Soil at 39 in. & 1.6 & jet fuel \\
\hline Soil at $72 \mathrm{in.}$ & 4.5 & jet fuel \\
\hline Groundwater at 72 in. & $<10$ & - \\
\hline
\end{tabular}

a Refer to Figures 3.1 to 3.4 for test pit locations. 1 in. $=2.54 \mathrm{~cm}$.

b Analysis made by gas chromatography.

c < Indicates compounds not detected at detection limit shown. 
Table 4.14. Concentrations of total petroleum hydrocarbons measured in soil and groundwater samples collected from the diesel fuel tank site

by ORNL in February 1991

\begin{tabular}{lcc}
\hline Test pit a and depth & $\begin{array}{c}\text { Total hydrocarbon } \\
\text { concentration b }\end{array}$ & $\begin{array}{c}\text { Substance similarity } \\
\text { based on chromatograph }\end{array}$ \\
\hline Test pit TP4 & 0.9 (est.) & diesel \\
Soil at 10 in. & 216 & diesel \\
Soil at 32 in. & 8920 & diesel \\
Soil at 65 in. & 265 & diesel \\
Groundwater at 65 in. & & diesel \\
Test pit TP5 & 490 & diesel \\
Soil at 62 in. & 110 & \\
Groundwater at 62 in. & & \\
\hline
\end{tabular}

a Refer to Fig. 3.1 to 3.4 for test pit locations. 1 in. $=2.54 \mathrm{~cm}$.

b Analysis conducted in ORNL laboratories by gas chromatography. 
Table 4.15. Concentrations of semivolatile hydrocarbons measured in soil and groundwater samples collected from the desalination plant site by ORNL in February 1991

\begin{tabular}{|c|c|c|c|}
\hline Test pit $\mathbf{a}$ and depth & $\begin{array}{l}\text { Total SVOC } \\
\text { concentration b }\end{array}$ & $\begin{array}{l}\text { Typical } \\
\text { detection } \\
\text { limits }\end{array}$ & Compounds detected \\
\hline & $\begin{array}{l}\mathrm{mg} / \mathrm{kg} \text { or } \\
\mathrm{mg} / \mathrm{L}\end{array}$ & $\begin{array}{l}\mathrm{mg} / \mathrm{kg} \text { or } \\
\mathrm{mg} / \mathrm{L}\end{array}$ & \\
\hline \multicolumn{4}{|l|}{ Test pit TP1 } \\
\hline Soil at $08 \mathrm{in.}$ & 4.96 & $\begin{array}{l}0.3- \\
1.7\end{array}$ & $\begin{array}{l}\text { trace amounts of } \\
\text { phenanthrene, fluoranthene, } \\
\text { di-n-butyl phthalate, pyrene, } \\
\text { benzo(a)anthracene, } \\
\text { chrysene and } \\
\text { benzo(a)pyrene }\end{array}$ \\
\hline Soil at 33 in. & $x^{c}$ & $\begin{array}{l}0.3- \\
1.6\end{array}$ & - \\
\hline Soil at 56 in. & $\mathbf{x}$ & $\begin{array}{l}0.3- \\
1.6\end{array}$ & - \\
\hline Groundwater at 56 in. & $\mathbf{x}$ & $\begin{array}{c}0.06 \\
0.3\end{array}$ & - \\
\hline \multicolumn{4}{|l|}{ Test pit TP2 } \\
\hline Groundwater at 65 in. & $\mathbf{x}$ & $\begin{array}{l}0.08- \\
0.43\end{array}$ & - \\
\hline \multicolumn{4}{|l|}{ Test pit TP3 } \\
\hline Soil at 12 in. & 0.1 & $\begin{array}{l}0.30- \\
1.6\end{array}$ & $\begin{array}{l}\text { trace amount of } \\
\text { phenanthrene estimated }\end{array}$ \\
\hline Soil at 39 in. & $\mathbf{x}$ & $\begin{array}{l}0.30- \\
1.5\end{array}$ & - \\
\hline Soil at 72 in. & $\mathbf{x}$ & $\begin{array}{l}0.30- \\
1.6\end{array}$ & - \\
\hline Groundwater at 72 in. & $\mathbf{x}$ & $\begin{array}{l}0.06- \\
0.30\end{array}$ & - \\
\hline
\end{tabular}

a Refer to Fig. 3.1 to 3.4 for test pit locations. 1 in. $=2.54 \mathrm{~cm}$.

b Analysis conducted in ORNL laboratories by gas chromatography-mass spectroscopy in conformance with U.S. Environmental Protection Agency methods for 65 semivolatiles on the target compound list.

c $\mathbf{x}$ Indicates semivolatiles not detected at the detection limits shown. 
Table 4.16. Concentrations of semivolatile hydrocarbons measured in soil and groundwater samples collected from the diesel fuel tank site by ORNL in February 1991

\begin{tabular}{|c|c|c|c|}
\hline Test pit $\mathrm{a}$ and depth & $\begin{array}{l}\text { Total SVOC } \\
\text { concentration b }\end{array}$ & $\begin{array}{c}\text { Typical } \\
\text { detection } \\
\text { limit }\end{array}$ & Compounds detected \\
\hline & $\begin{array}{c}\mathrm{mg} / \mathrm{kg} \text { or } \\
\mathrm{mg} /\end{array}$ & $\underset{\mathrm{mg} / \mathrm{kg} \text { or }}{\mathrm{mg}}$ & \\
\hline \multicolumn{4}{|l|}{ Test pit TP4 } \\
\hline Soil at $10 \mathrm{in.}$ & $x^{c}$ & $\begin{array}{c}0.30- \\
1.6\end{array}$ & - \\
\hline Soil at 32 in. & $\mathbf{x}$ & $\begin{array}{l}0.03- \\
0.16\end{array}$ & - \\
\hline Soil at 65 in. & $0.07 \mathrm{~d}$ & $\begin{array}{l}0.03- \\
0.16\end{array}$ & 4,6-dinitro-2-methylphenol \\
\hline Groundwater at $65 \mathrm{in}$. & $0.15^{d}$ & $\begin{array}{c}0.06- \\
0.16\end{array}$ & bis(2-ethylhexyl)phthalate \\
\hline \multicolumn{4}{|l|}{ Testpit TP5 } \\
\hline Soil at 62 in. &.$d$ & $4.1-$ & $-d$ \\
\hline Groundwater at 62 in. & $-d$ & $\begin{array}{c}0.03- \\
0.08\end{array}$ & $-d$ \\
\hline
\end{tabular}

a Refer to Fig. 3.1 to 3.4 for test pit locations. 1 in. $=2.54 \mathrm{~cm}$.

b Analyses conducted in ORNL laboratories by gas chromatography-mass spectroscopy in conformance with U.S. Environmental Protection Agency methods for semivolatiles on the target compound list.

c $\mathrm{x}$ Indicates semivolatiles not detected at detection limits shown.

d Unknown hydrocarbons detected, but not quantified; several appeared to be napthalenes. 
Table 4.17. Concentrations of volatile hydrocarbons measured in soil and groundwater samples collected from the desalination plant site by ORNL in February 1991

\begin{tabular}{|c|c|c|c|}
\hline Test pit $\mathbf{a}$ and depth & $\begin{array}{l}\text { Total volatile } \\
\text { organic } \\
\text { compound } \\
\text { concentrationb }\end{array}$ & $\begin{array}{c}\text { Typical } \\
\text { detection } \\
\text { limit }\end{array}$ & Compounds detected \\
\hline & ug/kg or ug/L & $\begin{array}{c}\text { ug/kg or } \\
\text { ug } h\end{array}$ & \\
\hline \multicolumn{4}{|l|}{ Test pit TP1 } \\
\hline Soil at 08 in. & $x^{c}$ & $5-10$ & - \\
\hline Soil at $33 \mathrm{in.}$ & $\mathbf{x}$ & $5-10$ & - \\
\hline Soil at 56 in. & $\mathbf{x}$ & $5-10$ & - \\
\hline \multicolumn{4}{|l|}{ Test pit TP2 } \\
\hline Soil at $63 \mathrm{in.}$ & 53 & $5 \cdot 10$ & carbon disulfide, chlorobenzene \\
\hline Groundwater at $65 \mathrm{in}$. & 11 & $5 \cdot 10$ & chloroform \\
\hline \multicolumn{4}{|l|}{ Test pit TP3 } \\
\hline Soil at 12 in. & 8 & $5-10$ & 1,1,1-trichloroethane \\
\hline Soil at 39 in. & $\mathbf{x}$ & $5-10$ & $\cdot$ \\
\hline Soil at 72 in. & 13 & $5-10$ & 1,1,1-trichloroethane \\
\hline Groundwater at 72 in. & 67 & $5 \cdot 10$ & chloroform, 1,1,1-trichloroethane \\
\hline
\end{tabular}

a Refer to Fig. 3.1 to 3.4 for test pit locations. $1 \mathrm{in} .=2.54 \mathrm{~cm}$.

b Analyses conducted in ORNL laboratories by gas chromatography-mass spectroscopy in conformance with U.S. Environmental Protection Agency methods for volatiles on the target compound list.

c " $x$ " Indicates volatiles not detected at detection limits shown. 
Table 4.18. Concentrations of volatile hydrocarbons measured in soil and groundwater samples collected from the diesel tank site by ORNL in February 1991

\begin{tabular}{|c|c|c|c|}
\hline Test pit ${ }^{a}$ and depth & $\begin{array}{l}\text { Total volatile } \\
\text { organic } \\
\text { compound } \\
\text { concentration b }\end{array}$ & $\begin{array}{c}\text { Typical } \\
\text { detection } \\
\text { limit }\end{array}$ & Compounds detected \\
\hline Test pit TP4 & ug/kg or ug $/ L$ & $\begin{array}{c}\mathrm{ug} / \mathrm{kg} \text { or } \\
\mathrm{ug} /\end{array}$ & \\
\hline Soil at $10 \mathrm{in.}$ & $x^{c}$ & $5 \cdot 10$ & - \\
\hline Soil at 32 in. & 160 & $5-10$ & acetone \\
\hline Soil at 65 in. & $\mathbf{x}$ & $5 \cdot 10$ & $\cdot$ \\
\hline Groundwater at 65 in. & 580 & $5-50$ & acetone \\
\hline \multicolumn{4}{|l|}{ Test pit TP4 } \\
\hline Soil at 62 in. & $-d$ & $5-10$ & $-d$ \\
\hline Groundwater at 62 in. & $53 \mathrm{~d}$ & $5-10$ & carbon disulfide, chlorobenzene ${ }^{d}$ \\
\hline
\end{tabular}

a Refer to Fig. 3.1 to 3.4 for test pit locations. 1 in. $=2.54 \mathrm{~cm}$.

b Analyses conducted in ORNL laboratories by gas chromatography-mass spectroscopy in conformance with U.S. Environmental Protection Agency methods for volatiles on the target compound list.

c $\mathrm{x}$ Indicates volatiles not detected at detection limits shown.

d Unknown hydrocarbons detected, but not quantified; several appeared to be napthalenes. 
Table 4.19. Concentrations of heavy metals measured in soil and groundwater samples collected from the desalination plant site by ORNL in February 1991

\begin{tabular}{|c|c|c|c|c|c|c|c|c|}
\hline Test pit ${ }^{a}$ and depth & $\mathrm{Ag}$ & As & $\mathrm{Ba}$ & $\mathrm{Cd}$ & $\mathrm{Cr}$ & $\mathrm{Hg}$ & $\mathrm{Pb}$ & $\mathrm{Se}$ \\
\hline & $\mathrm{mg} / \mathrm{kg}$ & $\mathrm{mg} / \mathrm{kg}$ & $\mathrm{mg} / \mathrm{kg}$ & $\mathrm{mg} / \mathrm{kg}$ & $\mathrm{mg} / \mathrm{kg}$ & $\mathrm{mg} / \mathrm{kg}$ & $\mathrm{mg} / \mathrm{kg}$ & $\mathrm{mg} / \mathrm{kg}$ \\
\hline \multicolumn{9}{|l|}{ Testpit TP1 } \\
\hline Soil at 08 in. & $<1.6^{b}$ & $<16$ & 7.7 & $<1.6$ & 12 & 0.01 & 38 & $<16$ \\
\hline Soil at 33 in. & $<1.7$ & $<17$ & 4.7 & $<1.7$ & 11 & $<0.01$ & $<17$ & $<17$ \\
\hline \multirow[t]{2}{*}{ Soil at 56 in. } & 1.7 & $<16$ & 5.7 & $<1.6$ & 11 & $<0.01$ & $<16$ & $<16$ \\
\hline & ug/L & ug/L & ug/L & ug/L & ug/L & $\mathrm{ug} / \mathrm{L}$ & ug/L & ug/L \\
\hline $\begin{array}{l}\text { Groundwater } \\
\text { at } 56 \text { in. }\end{array}$ & $<5.0$ & $<50.0$ & $<1.0$ & $<5.0$ & 19 & $<10$ & $<50.0$ & $<50.0$ \\
\hline \multicolumn{9}{|l|}{ Test pit TP3 } \\
\hline Soil at 12 in. & $<1.6^{b}$ & $<1.6$ & 6.5 & $<1.6$ & 13 & 0.02 & $<16$ & $<16$ \\
\hline Soil at 39 in. & $<1.6$ & $<16$ & 5.3 & $<1.6$ & 11 & $<0.01$ & $<16$ & $<16$ \\
\hline \multirow[t]{2}{*}{ Soil at 72 in. } & $<1.5$ & $<15$ & 4.2 & $<1.5$ & 9 & $<0.01$ & $<15$ & $<15$ \\
\hline & $\mathrm{ug} / \mathrm{L}$ & ug/L & $\mathrm{ug} / \mathrm{L}$ & $\mathrm{ug} / \mathrm{L}$ & $\mathrm{ug} / \mathrm{L}$ & $\mathrm{ug} / \mathrm{L}$ & $\mathrm{ug} / \mathrm{L}$ & $\mathrm{ug} / \mathrm{L}$ \\
\hline $\begin{array}{l}\text { Groundwater } \\
\text { at } 72 \text { in. }\end{array}$ & $<5.0$ & $<50.0$ & $<1.0$ & $<5.0$ & 22 & $<10$ & $<50.0$ & $<50.0$ \\
\hline
\end{tabular}

a Refer to Fig. 3.1 to 3.4 for test pit locations. $1 \mathrm{in.}=2.54 \mathrm{~cm}$. Analyses conducted in ORNL laboratories.

b < Indicates heavy metal not detected at detection limit shown. 
Table 4.20. Concentrations of heavy metals measured in soil and groundwater samples collected from the diesel fuel tank site by ORNL in February 1991

\begin{tabular}{|c|c|c|c|c|c|c|c|c|}
\hline Test pit ${ }^{a}$ and depth & $\mathrm{Ag}$ & As & $\mathrm{Ba}$ & $\mathrm{Cd}$ & $\mathrm{Cr}$ & $\mathrm{Hg}$ & $\mathrm{Pb}$ & $\mathrm{Se}$ \\
\hline Test pit TP4 & $\mathrm{mg} / \mathrm{kg}$ & $\mathrm{mg} / \mathrm{kg}$ & $\mathrm{mg} / \mathrm{kg}$ & $\mathrm{mg} / \mathrm{kg}$ & $\mathrm{mg} / \mathrm{kg}$ & $\mathrm{mg} / \mathrm{kg}$ & $\mathrm{mg} / \mathrm{kg}$ & $\mathrm{mg} / \mathrm{kg}$ \\
\hline Soil at 10 in. & $<1.5^{b}$ & $<15$ & 6.1 & $<1.5$ & 11 & $<0.01$ & $<15$ & $<15$ \\
\hline Soil at 32 in. & $<1.6$ & $<16$ & 4.8 & $<1.6$ & 8.6 & $<0.01$ & $<16$ & $<16$ \\
\hline Soil at 65 in. & $<1.6$ & $<16$ & 5.1 & $<1.6$ & 8.8 & $<0.01$ & $<16$ & $<16$ \\
\hline & ug/L. & ug/L & ug/L & ug $/ \mathrm{L}$ & ug/L & ug/L & ug $/ \mathrm{L}$ & ug/L \\
\hline $\begin{array}{l}\text { Groundwater } \\
\text { at } 65 \text { in. }\end{array}$ & $<25$ & $<250$ & $<5.0$ & - & 23 & $<10$ & $<250$ & - \\
\hline
\end{tabular}

a Refer to Fig. 3.1 to 3.4 for test pit locations. 1 in. $=2.54 \mathrm{~cm}$.

Analyses conducted in ORNL laboratories.

b < Indicates heavy metal not detected at detection limit shown. 
Table 4.21. Low-level radiochemical analyses of soil and groundwater samples collected from the desalination plant site and the diesel tank site by ORNL in February 1991

\begin{tabular}{lcc}
\hline Test pit a and depth & Gross Alpha & Gross Beta \\
\hline Test pit TP3 & Bq/kg & Bq/kg \\
Soil at 12 in. & $70+/-100$ & $10+/-120$ \\
Soil at 39 in. & $76+/-90$ & $60+/-120$ \\
Soil at 72 in. & $18+/-7$ & $20+/-180$ \\
& & \\
\hline Test pit TP4 & $72+/-85$ & $120+/-100$ \\
Soil at 10 in. & $5+/-48$ & $130+/-170$ \\
Soil at 32 in. & $-21+/-54$ & $-110+/-240$ \\
Soil at 65 in. & $430+/-600$ & $1200+/-1400$ \\
Groundwater at 65 in. & & \\
\hline
\end{tabular}

a Refer to Fig. 3.1 to 3.4 for test pit locations. 1 in. $=2.54 \mathrm{~cm}$.

Analyses conducted in ORNL laboratories. 
Table 4.22. Microbiological properties of soil and groundwater samples collected on Kwajalein Island during February 1991

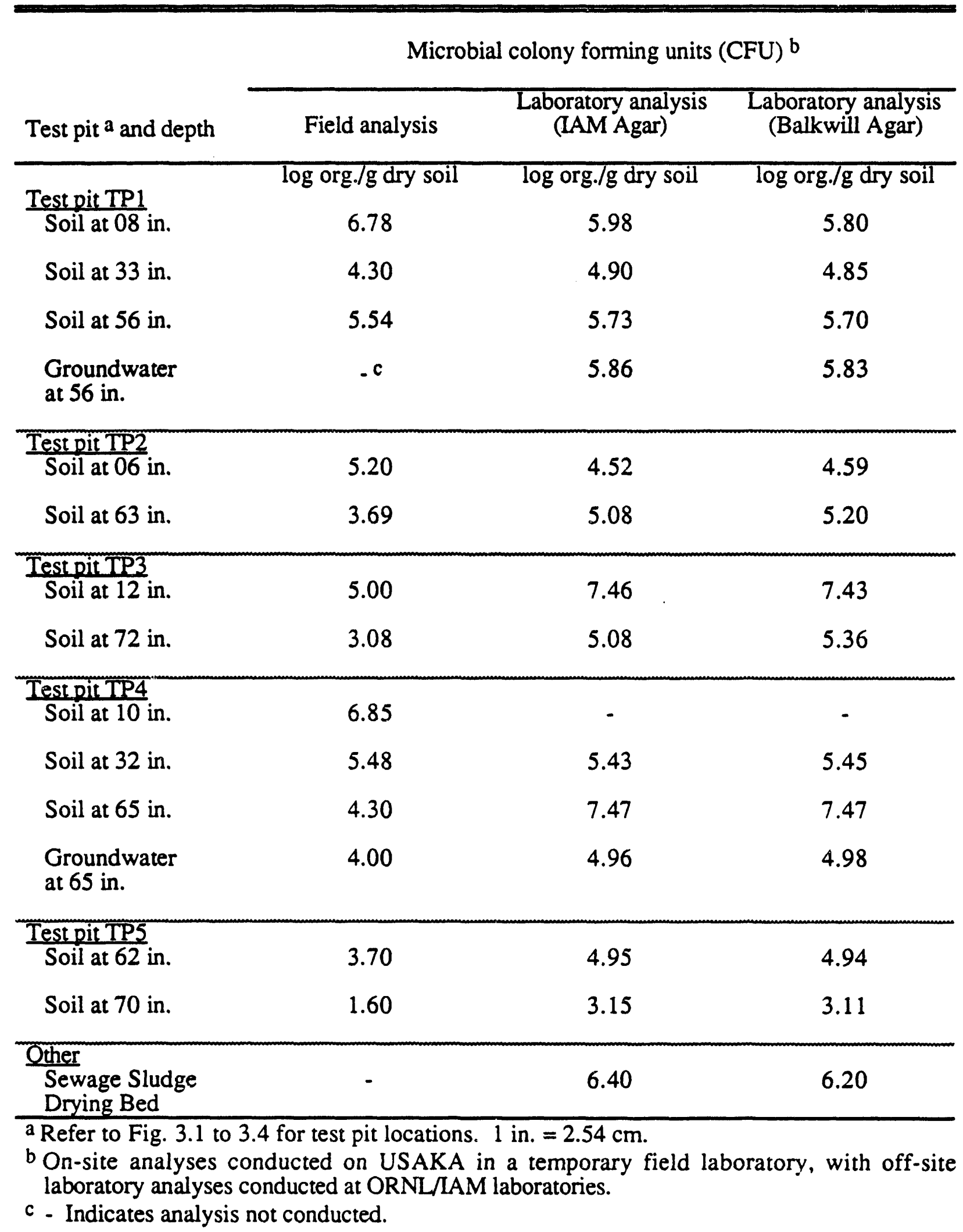


Table 4.23. Results of on-site microcosm experiments conducted with soil samples collected on Kwajalein Island during February 1991

\begin{tabular}{|c|c|c|c|c|}
\hline \multirow[b]{3}{*}{ Test pit $\mathrm{a}$ and depth } & \multicolumn{4}{|c|}{ Microbiologic analysis b } \\
\hline & \multirow[b]{2}{*}{$\begin{array}{l}\text { Field analysis } \\
\text { CFU }\end{array}$} & \multirow[b]{2}{*}{$\begin{array}{l}\text { Enrichment } \\
\text { tubes }\end{array}$} & \multicolumn{2}{|c|}{ Most probable number } \\
\hline & & & $\begin{array}{c}\text { Fuel } \\
\text { degraders }\end{array}$ & $\begin{array}{c}\text { BTEX } \\
\text { degraders }\end{array}$ \\
\hline & Log org./g & Log org./g & Log org./g & Log org./g \\
\hline$\frac{\text { Test pit TP1 }}{\text { Soil at } 08 \text { in. }}$ & 6.78 & $>4$ & 3 & 3 \\
\hline Soil at 33 in. & 4.30 & $>4$ & 0 & 0 \\
\hline Soil at 56 in. & 5.54 & $>4$ & 0 & 0 \\
\hline $\begin{array}{l}\text { Groundwater } \\
\text { at } 56 \text { in. }\end{array}$ & $-c$ & - & - & - \\
\hline$\frac{\text { Test pit TP2 }}{\text { Soil at } 06 \text { in. }}$ & 5.20 & $>4$ & 0 & 0 \\
\hline Soil at 63 in. & 3.69 & 3 & 3 & 3 \\
\hline$\frac{\text { Test pit TP3 }}{\text { Soil at } 12 \text { in. }}$ & 5.00 & $>4$ & 0 & 0 \\
\hline Soil at 72 in. & 3.08 & 3 & 3 & 0 \\
\hline$\frac{\text { Test pit TP4 }}{\text { Soil at } 10 \text { in. }}$ & 6.85 & 6 & 3 & 3 \\
\hline Soil at 32 in. & 5.48 & 6 & 3 & 3 \\
\hline Soil at 65 in. & 4.30 & 4 & 3 & 0 \\
\hline $\begin{array}{l}\text { Groundwater } \\
\text { at } 65 \text { in. }\end{array}$ & 4.00 & 4 & 3 & 3 \\
\hline$\frac{\text { Test pit TP5 }}{\text { Soil at } 62 \text { in. }}$ & 3.70 & 3 & 3 & 3 \\
\hline Soil at 70 in. & 1.60 & 3 & 3 & 3 \\
\hline
\end{tabular}

a Refer to Fig. 3.1 to 3.4 for test pit locations. 1 in. $=2.54 \mathrm{~cm}$.

b On-site analyses conducted on USAKA in a temporary field laboratory, with off-site laboratory analyses conducted at ORNL/LAM laboratories.

c - Indicates analysis not conducted. 
Table 4.24. Results of on-site respiration experiments conducted with soil samples collected on Kwajalein Island during February 1991

\begin{tabular}{|c|c|c|}
\hline \multirow{2}{*}{$\begin{array}{l}\text { Test pit } b \text { sample and } \\
\text { amendments }\end{array}$} & \multicolumn{2}{|c|}{ Respirometer conditions ${ }^{a}$ and results } \\
\hline & Cumulative $\mathrm{O}_{2}$ uptake & Cumulative $\mathrm{CO}_{2}$ evolved \\
\hline & $\mathrm{uLO}_{2}$ & $\mathrm{uLCO}$ \\
\hline Test pit TP1 & \multicolumn{2}{|c|}{$\begin{array}{l}40 \mathrm{~h} \text { incubation at } 24^{\circ} \mathrm{C} \text { for a composite sample of soil } \\
\text { from } 8-(28 \%), 33-(32 \%) \text {, and } 56-\text { in. }(40 \%) \text { depths } \\
\text { water content }=16.2 \% \text { by wt }\end{array}$} \\
\hline $\begin{array}{l}\text { Soil + amendments: } \mathrm{c} \\
\text { Nutrients } \\
\text { Nutrients + fuel } \\
\text { Nutrients + fuel }+\mathrm{NaOH} \\
10 \text { mL of groundwater } \\
\text { Blank }\end{array}$ & $\begin{array}{r}3700 \\
6700 \\
1700 \\
2500 \\
0\end{array}$ & $\begin{array}{l}-d \\
- \\
- \\
- \\
-\end{array}$ \\
\hline Testpit TP4 & \multicolumn{2}{|c|}{$\begin{array}{l}83 \mathrm{~h} \text { incubation at } 24^{\circ} \mathrm{C} \text { of composite sample of soil } \\
\text { from } 10-(22 \%), 22-(51 \%) \text {, and } 65-\text { in. (27\%) depths }\end{array}$} \\
\hline $\begin{array}{l}\text { Soil + amendments: } \\
\text { Nutrients } \\
\text { Nutrients + fuel } \\
\text { None } \\
\text { Blank }\end{array}$ & $\begin{array}{r}10800 \\
12000 \\
550 \\
0\end{array}$ & $\begin{array}{r}17000 \\
20000 \\
5000 \\
<200\end{array}$ \\
\hline Test Dit TP5 & \multicolumn{2}{|c|}{$\begin{array}{l}46 \mathrm{~h} \text { incubation at } 24^{\circ} \mathrm{C} \text { of composite sample of soil } \\
\text { from } 8-, 33-\text {, and } 56 \text {-in. depths }\end{array}$} \\
\hline $\begin{array}{l}\text { Soil + amendments: } \\
\text { Nutrients } \\
\text { Nutrients + fuel } \\
\text { None } \\
\text { Blank }\end{array}$ & $\begin{array}{r}7900 \\
6000 \\
2400 \\
0 \\
\end{array}$ & $\begin{array}{r}6500 \\
6600 \\
900 \\
<100 \\
\end{array}$ \\
\hline \multicolumn{3}{|c|}{$\begin{array}{l}\text { a Field moist soil weight per respirometer }=200 \mathrm{~g}+/-5 \% \text {. } \\
\text { b Refer to Figures } 3.1 \text { to } 3.4 \text { for test pit locations. Analyses conducted on Kwajalein Island. } \\
\text { c Amendment concentrations based on field moist soil weight. } \\
\text { Groundwater collected from respective test pit. } \\
\text { Nutrient concentrations }=6 \mathrm{mg} / \mathrm{kg} \mathrm{N}, \mathrm{P}, \mathrm{K} ; 1-16 \mathrm{ug} / \mathrm{kg} \mathrm{S}, \mathrm{B}, \mathrm{Cu}, \mathrm{Fe}, \mathrm{Mn}, \mathrm{Mo}, \mathrm{Zn} ; 3 \mathrm{~mL} \\
\text { groundwater, total water }=10 \mathrm{~mL} \text {. } \\
\text { Fuel }=5000 \mathrm{mg} / \mathrm{kg} \text { fresh diesel fuel from USAKA. } \\
\text { NaOH }=0.25 \mathrm{~mL} 5 \mathrm{M} \text { NaOH. } \\
\text { d - Indicates analysis not conducted. }\end{array}$} \\
\hline
\end{tabular}




\section{SECTION 5}

\section{CONCLUSIONS AND RECOMMENDATIONS}

\subsection{CONCLUSIONS}

The site characterization and biotreatability studies described herein were conducted to assess the potential for bioremediation as an environmental restoration technique for petroleumcontaminated soils on Kwajalein Island. As a result of the investigations conducted during February 1991, the following conclusions have been reached.

1. The area proposed for construction of a fresh water production facility (a.k.a. desalination plant) is not contaminated by petroleum hydrocarbons at a level warranting further investigation or restoration. An area adjacent to an aboveground diesel storage tank southeast of the old power plant, however, exhibited significant soil and groundwater contamination by diesel fuel at levels well above normal thresholds used for initiating environmental restoration.

2. The subsurface soil materials in the study area on Kwajalein Island contained an abundant biomass, which was able to grow in the presence of and degrade diesel fuel contamination.

3. The subsurface exhibited no apparent adverse environmental conditions that would render bioremediation infeasible. High concentrations of diesel fuel which is likely weathered, high $\mathrm{pH}$, and nutrient deficiencies may somewhat hinder bioremediation processes, but these may be overcome by design and operation.

4. There appear to be no concentrations of heavy metals and other hazardous substances that would preclude application of bioremediation due to microbial toxicity nor that would require remediation by a nonbiotechnology.

\subsection{RECOMMENDATIONS}

Based on the results of this investigation, there are petroleum-contaminated soils on Kwajalein Island, and bioremediation appears to be a viable environmental restoration technique. Further experimentation and field demonstration are required to determine the design and operating conditions that would provide for optimum biodegradation and restoration of petroleumcontaminated soils to an acceptable level. 


\section{SECTION 6}

REFERENCES

1. Ground-Water Quality Survey No. 38-26-0357-90, U.S. Army Kwajalein Atoll. March 5-16, 1990, U.S. Army Environmental Hygiene Agency, Aberdeen Proving Ground, MD.

2. C.D. Hunt, Jr., and F.L. Peterson. Groundwater resources of Kwajalein Island, Marshall Islands. Technical Report No. 126, Water Resources Research Center, University of Hawaii, Honolulu, 1980.

3. Repair Versus Construction Analysis, DFSP Kwajalein, U.S. Army Kwajalein Atoll, 1990. Report of DFSC Project KWA89-4, Williams Brothers Engineering Company, Tulsa, OK, July 1990.

4. Safety and Health Plan for Soil and Ground-Water Contamination Study, Kwajalein Atoll, 1990, U.S. Army Environmental Hygiene Agency, Aberdeen Proving Ground, MD, Study 38-26-0365-90/91, October 1990.

5. Bioremediation Technology Demonstration at Kwajalein Atoll, Marshall Islands, Workplan for Site Characterization and Biotreatability Studies, Prepared by Oak Ridge National Laboratory for Hazardous Waste Remedial Actions Programs, February 1991.

6. Quality Control Requirements for Field Methods, DOE/HWP-69/R1, Hazardous Waste Remedial Actions Program (HAZWRAP), U.S. Department of Energy, Oak Ridge, TN, 1990.

7. Requirements for Quality Control of Analytical Data, DOE/HWP-65/R1, Hazardous Waste Remedial Actions Program (HAZWRAP), U.S. Department of Energy, Oak Ridge, TN, 1990.

8. Standard Operating Procedures for Site Characterizations, DOE/HWP-100, Hazardous Waste Remedial Actions Program (HAZWRAP), U.S. Department of Energy, Oak Ridge, TN, 1990.

9. ORNL Pollutant Assessments Group Procedures Manual, Oak Ridge National Laboratory, Grand Junction, Colorado, 1990.

10. Standard Methods for the Examination of Water and Wastewater, 17th edition, American Public Health Association, Washington D.C, 1990.

11. Methods of Soil Analysis, Soil Science Society of America Monograph No. 9, Madison, Wisconsin, Part I, 1965; Part II, 1982.

12. Deep Subsurface Microbiology Program, NPR-E Technical Workplan 6.0, U.S. Department of Energy, Idaho National Engineering Laboratory, July 1990.

13. Test Methods for Evaluation of Solid Waste, U.S. Environmental Protection Agency, Washington, D.C., 1986. 
14. R.A. Freeze and J.A. Cherry, Groundwater, Prentice-Hall, Inc., Englewood Cliffs, New Jersey, 07632, 1979.

15. A.T. Taylor. and G.L. Ashcroft, Physical Edaphology: The Physics of Irrigated and Nonirrigated Soils, W.H. Freeman and Company, San Francisco, 1972.

16. R.A. Jenkins, R.W. Holmberg, J.S. Wike, J.H. Moneyhun, and R.S. Brazell, Chemical and physical characterization of diesel juel smoke, ORNL/TM-9196, Oak Ridge National Laboratory, Oak Ridge, TN, 1983.

17. J.S. Latimer, E.J. Hoffman, G Hoffman, F.L. Fashing, and J.G. Quinn, Sources of Petroleum Hydrocarbons in Urban Runoff, Water, Air and Soil Pollution 52:1-21, 1990. 
SECTION 7

APPENDICES 
APPENDIX A:

DESCRIPTIVE LOGS OF BACKHOE TEST PITS 
OTn 1 oak aidge national Laboratopy

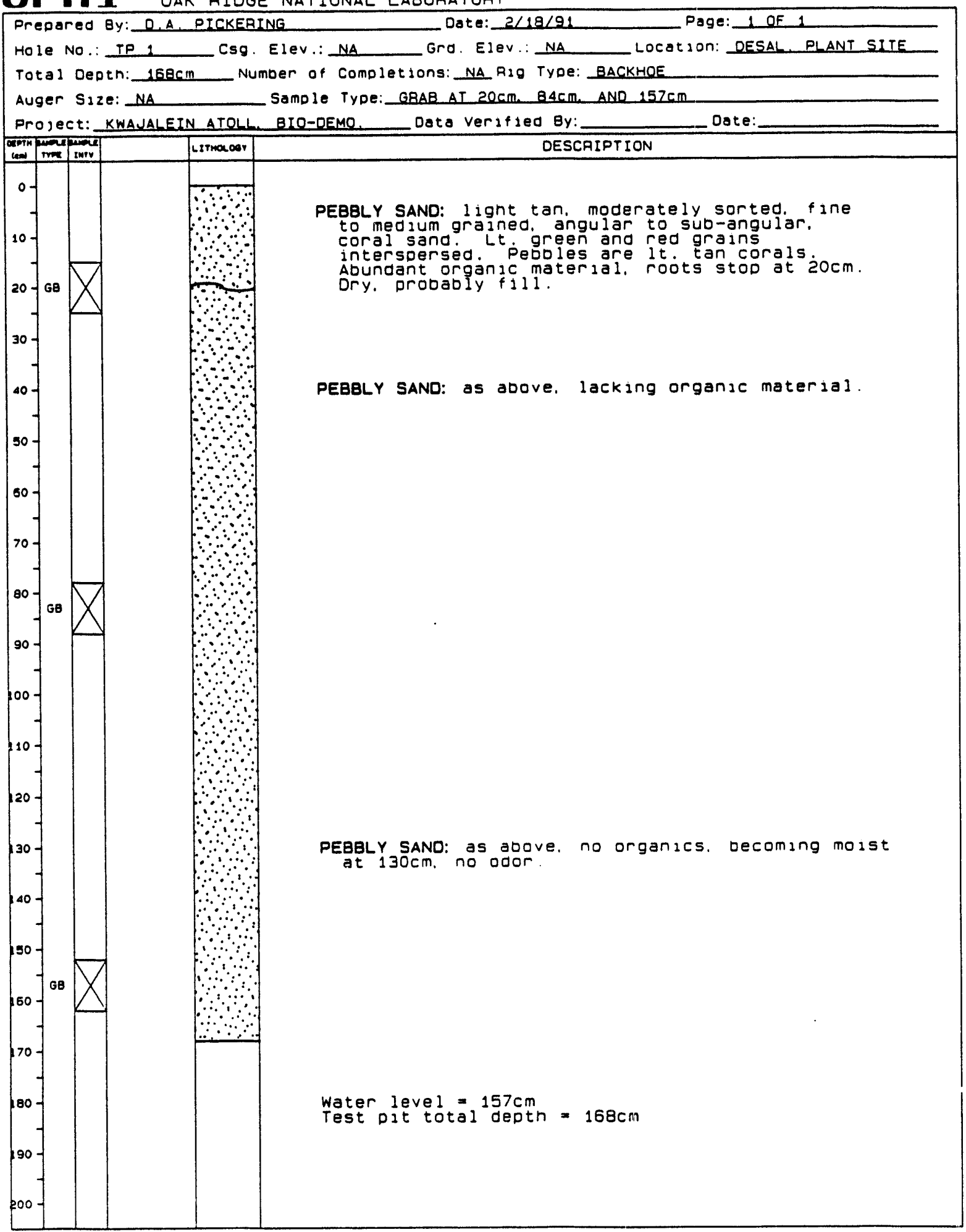


Test Pit Summary Information

QII OAK RIDGE NATIONAL LABORATORY

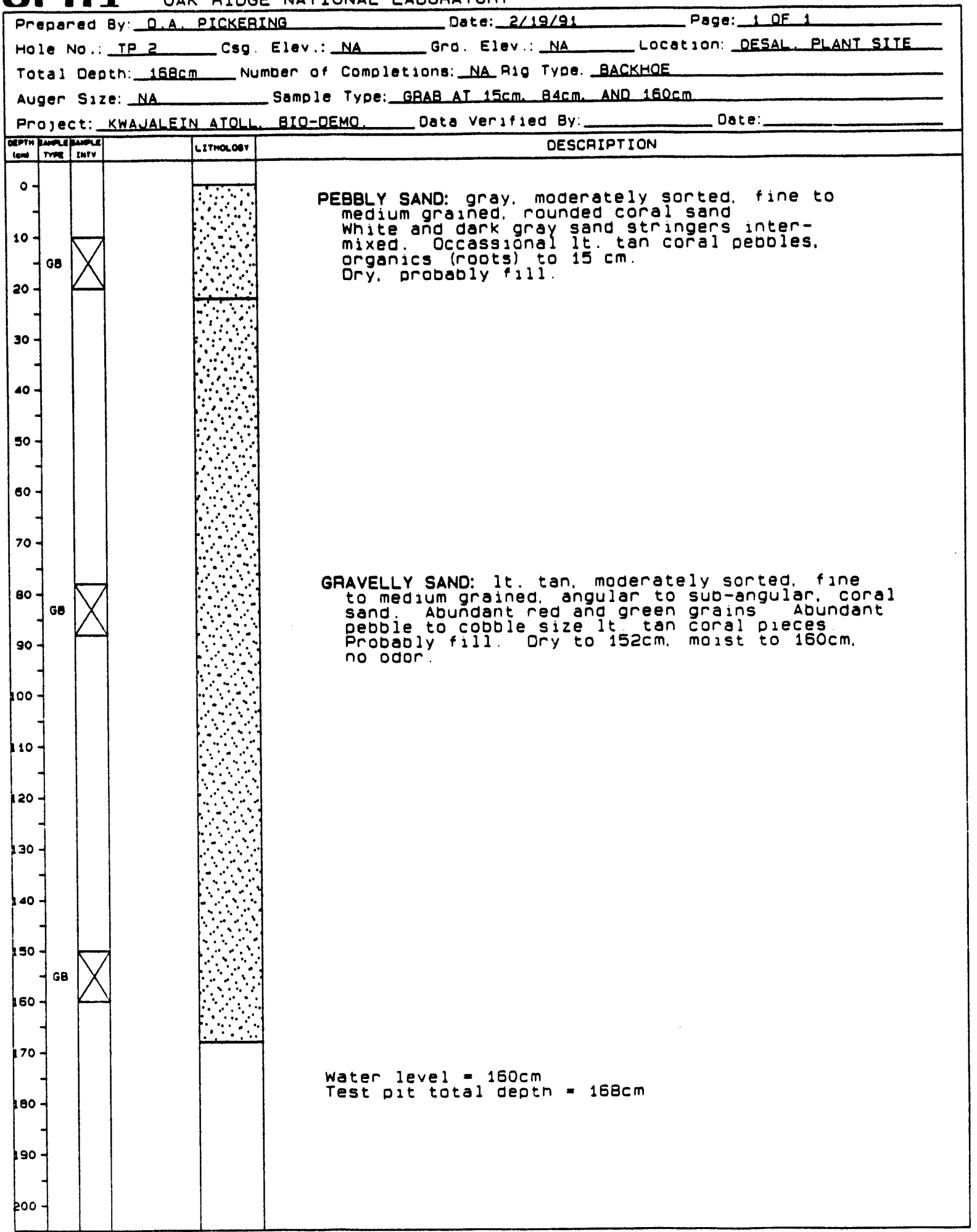


orn 1 oak Rioge national laboratory information

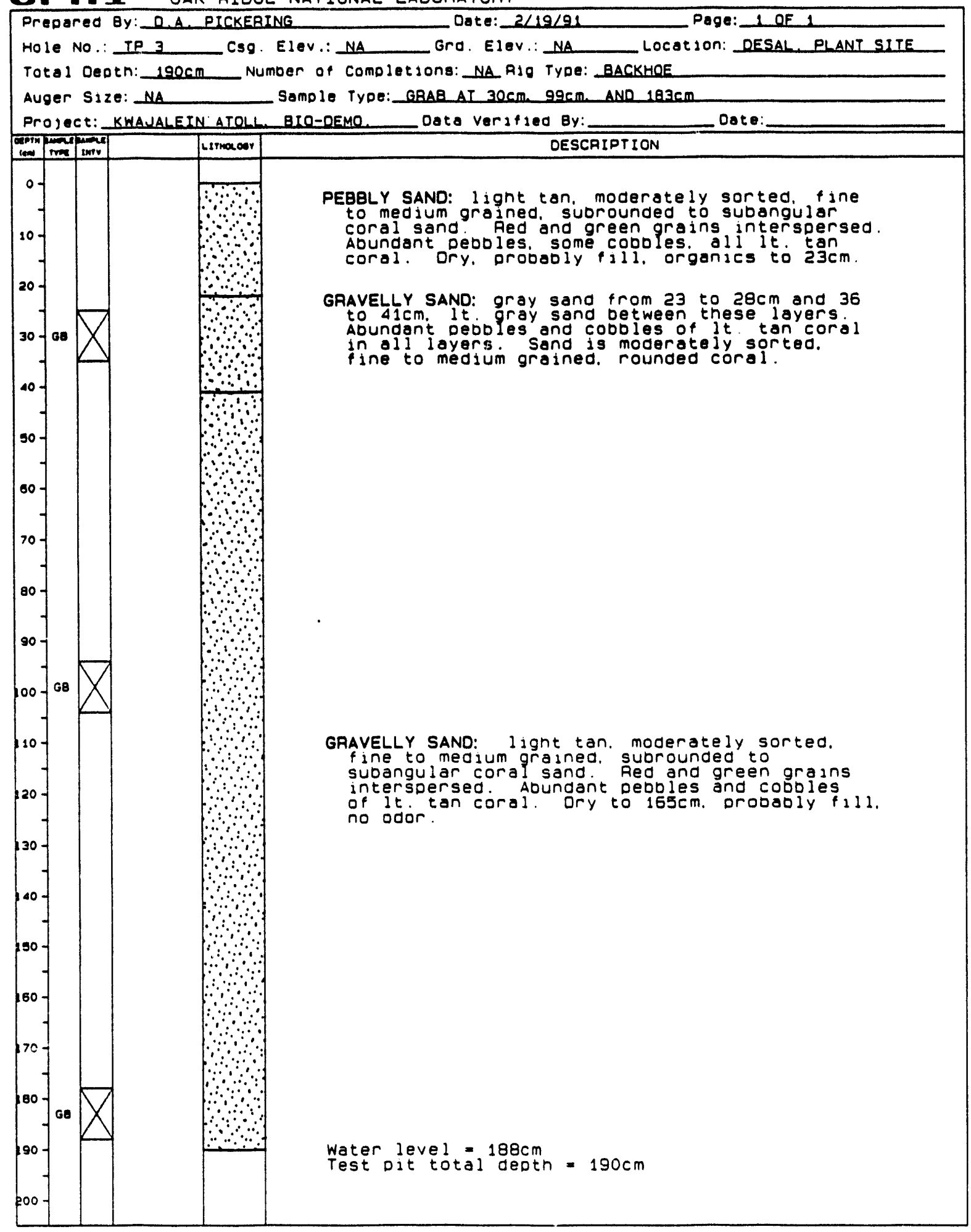




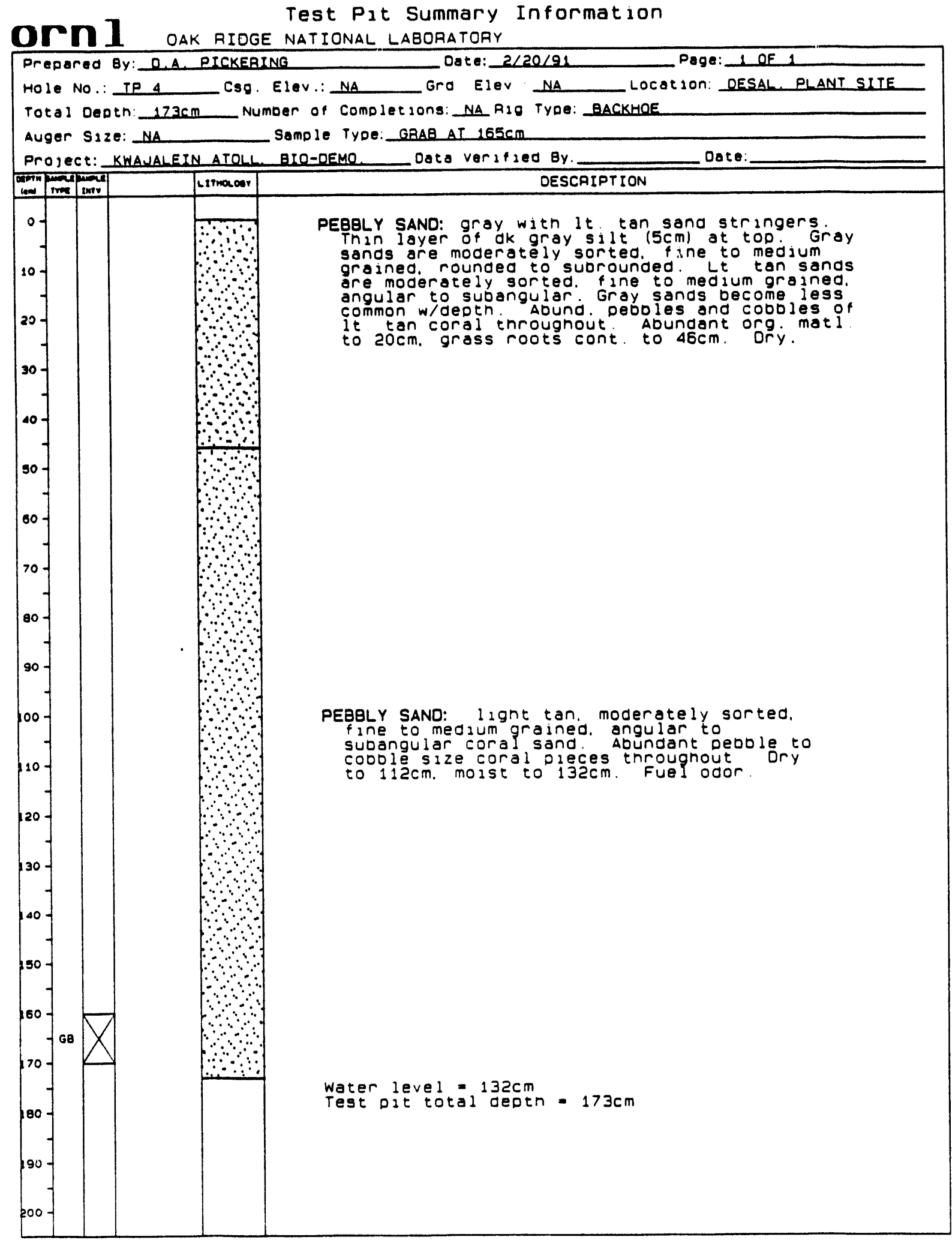




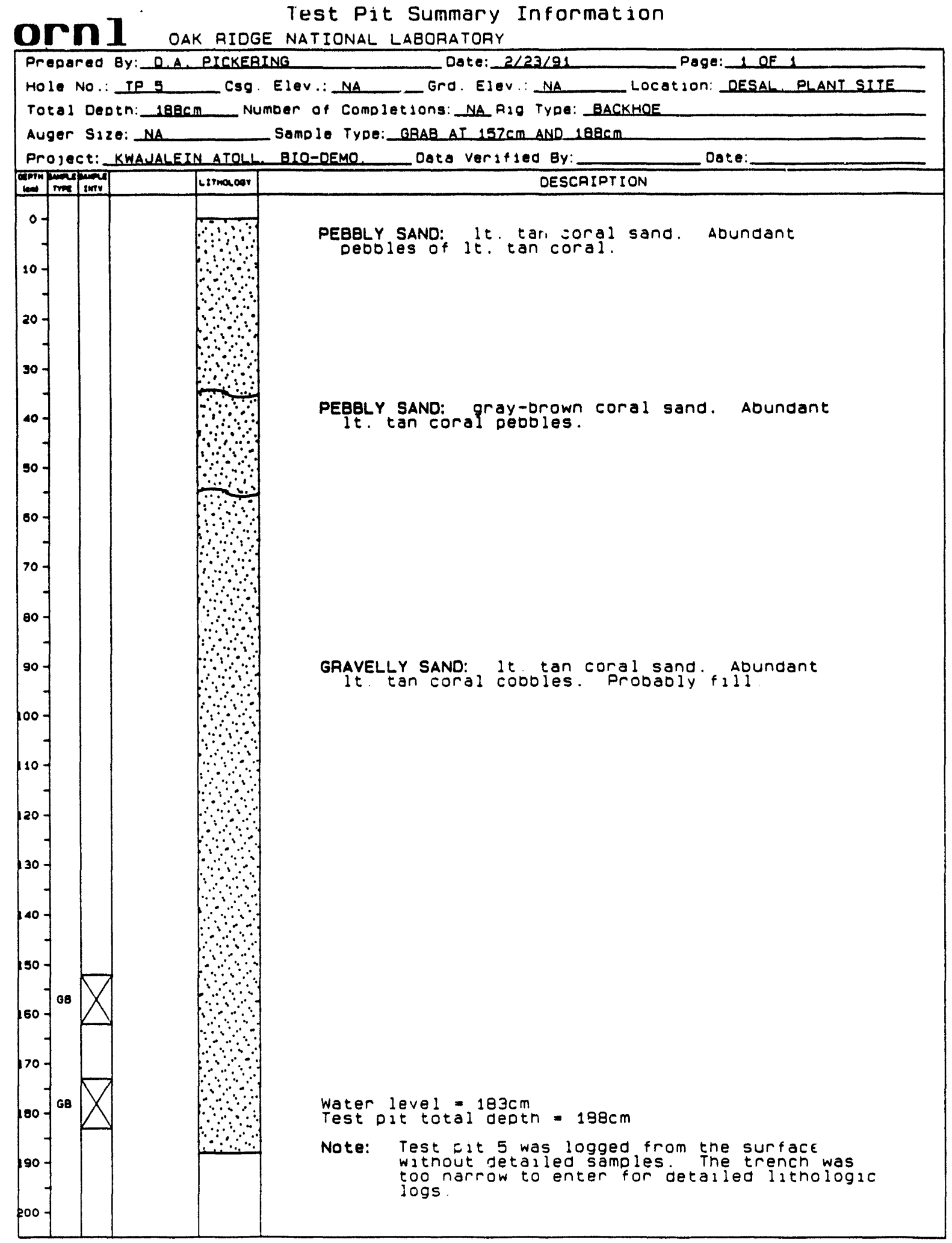


APPENDIX B

LISTING OF SAMPLES SUBMITTED FOR LABORATORY ANALYSES 
Table B.1. Organics analysis listing of samples returned to ORNL from $\mathrm{K}$ wajalein Island on Saturday, February 25, 1991

\begin{tabular}{|c|c|c|c|c|c|}
\hline $\begin{array}{l}\text { Field sample } \\
\text { ID }\end{array}$ & $\begin{array}{c}\text { Sample } \\
\text { description }\end{array}$ & $\begin{array}{c}\text { Sample } \\
\text { date }\end{array}$ & $\begin{array}{c}\text { Sample } \\
\text { time }\end{array}$ & Containers & $\begin{array}{l}\text { Organics analyses } \\
\text { requested }\end{array}$ \\
\hline $\begin{array}{l}\text { TP01-08 } \\
\text { TP01-33 } \\
\text { TP01-56 } \\
\text { TP01-W } \\
\text { TP01-W }\end{array}$ & $\begin{array}{l}\text { Soil @ } 8 \\
\text { Soil @ } 33 \\
\text { Soil @ 56 } \\
\text { Groundwater@ } 56 \\
\text { Groundwater@ } 56\end{array}$ & $\begin{array}{l}2 / 18 / 91 \\
2 / 18 / 91 \\
2 / 18 / 91 \\
2 / 18 / 91 \\
2 / 18 / 91\end{array}$ & $\begin{array}{l}18.15 \\
17.55 \\
17.05 \\
17.10 \\
17.10\end{array}$ & $\begin{array}{l}\text { 1, 250-mL Q-jar } \\
\text { 1, 250-mL Q-jar } \\
\text { 1, 250-mL Q-jar } \\
\text { 2, 40-mL I-VOA } \\
\text { 2, 40-mL I-VOA }\end{array}$ & $\begin{array}{c}\text { VOCs, SVOCs, TPH } \\
\text { VOCs, SVOCs, TPH } \\
\text { VOCs, SVOCs, TPH } \\
\text { VOCs } \\
\text { SVOCs, TPH }\end{array}$ \\
\hline $\begin{array}{l}\text { TP02-W } \\
\text { TP02-W }\end{array}$ & $\begin{array}{l}\text { Groundwater@63 } \\
\text { Groundwater @ 63 }\end{array}$ & $\begin{array}{l}2 / 19 / 91 \\
2 / 19 / 91\end{array}$ & $\begin{array}{l}14.45 \\
14.45\end{array}$ & $\begin{array}{l}2,40-\mathrm{mL} \text { I-VOA } \\
2,40-\mathrm{mL} \mathrm{I-VOA}\end{array}$ & $\begin{array}{c}\text { VOCs } \\
\text { sVOCs, TPH }\end{array}$ \\
\hline $\begin{array}{l}\text { TP03-12 } \\
\text { TP03-39 } \\
\text { TP03-72 } \\
\text { TPr:-W } \\
\text { TPO3-W }\end{array}$ & $\begin{array}{l}\text { Soil @ } 12 \\
\text { Soil @ } 39 \\
\text { Soil @ } 72 \\
\text { Groundwater@ } 72 \\
\text { Groundwater @ } 72\end{array}$ & $\begin{array}{l}2 / 19 / 91 \\
2 / 19 / 91 \\
2 / 19 / 91 \\
2 / 19 / 91 \\
2 / 19 / 91\end{array}$ & $\begin{array}{l}16.30 \\
16.50 \\
16.15 \\
16.30 \\
16.30\end{array}$ & $\begin{array}{l}1,250-\mathrm{mL} \text { I-jar } \\
1,250-\mathrm{mL} \text { I-jar } \\
1,250-\mathrm{mL} \text { I-jar } \\
2,40-\mathrm{mL} \text { I-VOA } \\
2,40-\mathrm{mL} \text { I-VOA }\end{array}$ & $\begin{array}{c}\text { VOCs, SVOCs, TPH } \\
\text { VOCs, SVOCs, TPH } \\
\text { VOCs, SVOCs, TPH } \\
\text { VOCs } \\
\text { SVOCs, TPH }\end{array}$ \\
\hline $\begin{array}{l}\text { TP04-10 } \\
\text { TP04-22 } \\
\text { TP04-65 } \\
\text { TPO4-W } \\
\text { TPO4-W }\end{array}$ & $\begin{array}{l}\text { Soil @ } 10 \\
\text { Soil @ } 32 \\
\text { Soil @65 } \\
\text { Groundwater@65 } \\
\text { Groundwater@ } 65\end{array}$ & $\begin{array}{l}2 / 20 / 91 \\
2 / 20 / 91 \\
2 / 20 / 91 \\
2 / 20 / 91 \\
2 / 20 / 91\end{array}$ & $\begin{array}{l}12.30 \\
12.40 \\
12.20 \\
11.40 \\
11.40\end{array}$ & $\begin{array}{l}1,250-\mathrm{mL} \text { I-jar } \\
1,250-\mathrm{mL} \text { I-jar } \\
1,250-\mathrm{mL} \text { I-jar } \\
2,40-\mathrm{mL} \text { I-VOA } \\
2,40-\mathrm{mL} \text { I-VOA }\end{array}$ & $\begin{array}{c}\text { VOCs, SVOCs, TPH } \\
\text { VOCs, SVOCs, TPH } \\
\text { VOCs, SVOCs, TPH } \\
\text { VOCs } \\
\text { SVOCs, TPH }\end{array}$ \\
\hline TP04-65A & Soil@ @ 65 & $2 / 20 / 91$ & 12.20 & 1, 40-mL I-VOA & VOCs by Standard \\
\hline TP04-65B & Soil @ 65 & $2 / 20 / 91$ & 12.20 & 1,40-mL I-VOA & $\begin{array}{c}\text { VOCs by MeOH In-vial } \\
\text { Extraction }\end{array}$ \\
\hline TP03-12A & Soil @ 12 & $2 / 19 / 91$ & 16.30 & $\begin{array}{l}1,40-\mathrm{mL} \text { I-VOA } \\
1,40-\mathrm{mL} \text { I-VOA }\end{array}$ & $\begin{array}{l}\text { VOCs by Standard } \\
\text { Method } \\
\text { VOCs by MeOH In-vial } \\
\text { Extraction }\end{array}$ \\
\hline TP03-12B & Soil @ 12 & $2 / 19 / 91$ & 16.30 & $1,40-\mathrm{mL}$ I-VOA & $\begin{array}{l}\text { VOCs by MeOH In-vial } \\
\text { Extraction }\end{array}$ \\
\hline TP01-56A & Soil @ 56 & $2 / 18 / 91$ & 17.05 & 1, 40-mL I-VOA & $\begin{array}{l}\text { VOCs by Standard } \\
\text { Metiod }\end{array}$ \\
\hline TP01-56B & Soil @ 56 & $2 / 18 / 91$ & 17.05 & 1,40-mL I-VOA & $\begin{array}{l}\text { VOCs by MeOH In-vial } \\
\text { Extraction }\end{array}$ \\
\hline Fuel & Diesel Fuel & $2 / 19 / 91$ & & $1,40-\mathrm{mL}$ I-VOA & VOCs, SVOCs, TPH \\
\hline TB03 & Trip Blank & $2 / 19 / 91$ & 9.30 & $2,40-\mathrm{mL}$ I-VOA & VOCs \\
\hline
\end{tabular}

Notes: $\quad$ Please analyze and prepare data package in accordance with HAZWRAP Level $C$ data quality for 6 samples: TP01-56; TP01-W; TP03-72; TP04-22; TP04-65; TP04-W.

Ánaiyticai metnods: VOCs by EPA $50300 / 8240$; S V VCS by $3550 / 8270$; TPH by 8000 .

Maintain all unused sample at $4^{\circ} \mathrm{C}$. Return all sample material to R.L. Siegrist. 
Table B.2. Organics Analysis Listing of Samples Returned to ORNL from Kwajalein Island on Saturday, March 2, 1991

\begin{tabular}{|c|c|c|c|c|c|}
\hline $\begin{array}{c}\text { Field } \\
\text { sample ID }\end{array}$ & $\begin{array}{c}\text { Sample } \\
\text { description }\end{array}$ & $\begin{array}{c}\text { Sample } \\
\text { date }\end{array}$ & $\begin{array}{l}\text { Sample } \\
\text { time }\end{array}$ & containers & $\begin{array}{l}\text { Organics analyses } \\
\text { requested }\end{array}$ \\
\hline $\begin{array}{l}\text { TB01 } \\
\text { TB02 } \\
\text { TB04 } \\
\text { TB05 } \\
\text { TB06 }\end{array}$ & $\begin{array}{l}\text { Trip Blank - water } \\
\text { Trip Blank - water } \\
\text { Trip Blank - water } \\
\text { Trip Blank - water } \\
\text { Trip Blank - water }\end{array}$ & $\begin{array}{l}2 / 19 / 91 \\
2 / 19 / 91 \\
2 / 19 / 91 \\
2 / 19 / 91 \\
2 / 19 / 91\end{array}$ & $\begin{array}{l}9.30 \\
9.30 \\
9.30 \\
9.30 \\
9.30\end{array}$ & $\begin{array}{l}2,40-\mathrm{mL} \text { I-VOA } \\
2,40-\mathrm{mL} \text { I-VOA } \\
2,40-\mathrm{mL} \text { I-VOA } \\
2,40-\mathrm{mL} \text { I-VOA } \\
2,40-\mathrm{mL} \mathrm{I-VOA}\end{array}$ & $\begin{array}{l}\text { VOCs } \\
\text { VOCs } \\
\text { VOCs } \\
\text { VOCs } \\
\text { VOCs }\end{array}$ \\
\hline $\begin{array}{l}\text { ER218 } \\
\text { ER218 }\end{array}$ & $\begin{array}{l}\text { Equipment Blank - water } \\
\text { Equipment Blank - water }\end{array}$ & $\begin{array}{l}2 / 18 / 91 \\
2 / 18 / 91\end{array}$ & $\begin{array}{l}18.15 \\
18.15\end{array}$ & $\begin{array}{l}2,40-\mathrm{mL} \text { I-VOA } \\
2,40-\mathrm{mL} \text { I-VOA }\end{array}$ & $\begin{array}{c}\text { VOCs } \\
\text { SVOCs, TPH }\end{array}$ \\
\hline $\begin{array}{l}\text { ER219 } \\
\text { ER219 }\end{array}$ & $\begin{array}{l}\text { Equipment Blank - water } \\
\text { Equipment Blank - water }\end{array}$ & $\begin{array}{l}2 / 19 / 91 \\
2 / 18 / 91\end{array}$ & $\begin{array}{l}18.15 \\
18.15\end{array}$ & $\begin{array}{l}2,40-\mathrm{mL} \mathrm{I-VOA} \\
2,40-\mathrm{mL} \mathrm{I}-\mathrm{VOA}\end{array}$ & $\begin{array}{c}\text { VOCs } \\
\text { SVOCs, TPH }\end{array}$ \\
\hline $\begin{array}{l}\text { ER220 } \\
\text { ER220 }\end{array}$ & $\begin{array}{l}\text { Equipment Blank - water } \\
\text { Equipment Blank - water }\end{array}$ & $\begin{array}{l}2 / 20 / 91 \\
2 / 20 / 91\end{array}$ & $\begin{array}{l}13.00 \\
13.00\end{array}$ & $\begin{array}{l}2,40-\mathrm{mL} \text { I-VOA } \\
2,40-\mathrm{mL} \text { I-VOA }\end{array}$ & $\begin{array}{c}\text { VOCs } \\
\text { sVOCs, TPH }\end{array}$ \\
\hline $\begin{array}{l}\text { FB01 } \\
\text { FB01 }\end{array}$ & $\begin{array}{l}\text { Field Blank - water } \\
\text { Field Blank - water }\end{array}$ & $\begin{array}{l}2 / 19 / 91 \\
2 / 19 / 91\end{array}$ & $\begin{array}{l}16.45 \\
16.45\end{array}$ & $\begin{array}{l}2,40-\mathrm{mL} \text { I-VOA } \\
2,40-\mathrm{mL} \mathrm{I-VOA}\end{array}$ & $\begin{array}{c}\text { VOCs } \\
\text { sVOCs, TPH }\end{array}$ \\
\hline $\begin{array}{l}\text { TP02-63 } \\
\text { TP02-63 } \\
\text { TP02-63 } \\
\text { MS } \\
\text { TP02-63 } \\
\text { MSD }\end{array}$ & $\begin{array}{l}\text { Soil @63 } \\
\text { Soil @ 63 } \\
\text { Soil @ 63 } \\
\text { Soil @ } 63\end{array}$ & $\begin{array}{l}2 / 19 / 91 \\
2 / 19 / 91 \\
2 / 19 / 91 \\
2 / 19 / 91\end{array}$ & $\begin{array}{l}14.30 \\
14.30 \\
14.30 \\
14.30\end{array}$ & $\begin{array}{c}4,40-\mathrm{mL} \text { I-VOA } \\
1,250 \mathrm{~mL} \mathrm{I-jar} \\
1,250 \mathrm{~mL} \mathrm{I-jar} \\
1,250 \mathrm{~mL} \mathrm{I-jar}\end{array}$ & $\begin{array}{l}\text { VOCs } \\
\text { VOCs, SVOCs, TPH } \\
\text { VOCs, SVOCs, TPH } \\
\text { VOCs, SVOCs, TPH }\end{array}$ \\
\hline $\begin{array}{l}\text { TP05-62 } \\
\text { TP05-62 } \\
\text { TP05-62A }\end{array}$ & $\begin{array}{l}\text { Soil @ } 62 \\
\text { Soil @62 } \\
\text { Soil @ } 62 \text { in } \\
\text { isopropanol }\end{array}$ & $\begin{array}{l}2 / 23 / 91 \\
2 / 23 / 91 \\
2 / 23 / 91\end{array}$ & $\begin{array}{l}13.05 \\
13.05 \\
13.05\end{array}$ & $\begin{array}{c}2,40-\mathrm{mL} \mathrm{I} \text { I-VOA } \\
1,250 \mathrm{~mL} \mathrm{I}-\mathrm{jar} \\
2,40-\mathrm{mL} \mathrm{I} \text {-VOA }\end{array}$ & $\begin{array}{l}\text { VOCs } \\
\text { VOCs. SVOCs, TPH } \\
\text { VOCs }\end{array}$ \\
\hline TPOS-62B & Soil @ 62 & $2 / 23 / 91$ & 13.05 & $1,250 \mathrm{~mL} \mathrm{I-jar}$ & VOCs, SVOCs, TPH \\
\hline $\begin{array}{l}\text { TPOS-W } \\
\text { TP05-W }\end{array}$ & $\begin{array}{l}\text { Groundwater@62 } \\
\text { Groundwater@62 }\end{array}$ & $\begin{array}{l}2 / 23 / 91 \\
2 / 23 / 91\end{array}$ & $\begin{array}{l}13.15 \\
13.15\end{array}$ & $\begin{array}{l}2,40-\mathrm{mL} \text { I-VOA } \\
2,40-\mathrm{mL} \mathrm{I-VOA}\end{array}$ & $\begin{array}{c}\text { VOCs } \\
\text { SVOCs, TPH }\end{array}$ \\
\hline
\end{tabular}

Notes: $\quad$ Please analyze and prepare data package in accordance with HAZWRAP Level C data quality for 6 samples: TB05, ER219, FB01, TP03-12, TP05-62.

Analytical methods: per U.S. EPA CLP protocols.

Maintain all unused sample at $4^{\circ} \mathrm{C}$. Return all sample material to R.L. Siegrist 
Table B.3. Inorganics analysis listing of samples returned to ORNL from Kwajalein Island on Saturday, February 25, 1991

\begin{tabular}{|c|c|c|c|c|}
\hline $\begin{array}{l}\text { Field sample } \\
\text { ID }\end{array}$ & $\begin{array}{c}\text { Sample } \\
\text { description }\end{array}$ & $\begin{array}{l}\text { Sample } \\
\text { date }\end{array}$ & $\begin{array}{c}\text { Sample } \\
\text { time }\end{array}$ & Containers \\
\hline \multicolumn{5}{|c|}{ 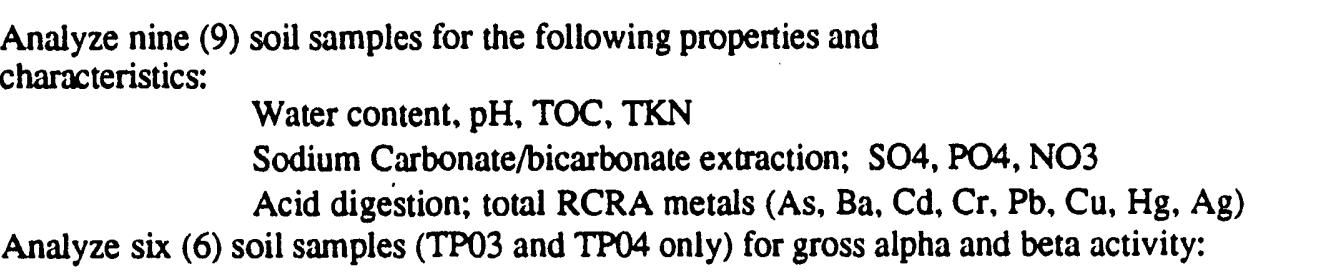 } \\
\hline $\begin{array}{l}\text { TP01-08 } \\
\text { TP01-33 } \\
\text { TP01-56 }\end{array}$ & $\begin{array}{l}\text { Soil @ } 8 \\
\text { Soil @ } 33 \\
\text { Soil @ } 56\end{array}$ & $\begin{array}{l}2 / 18 / 91 \\
2 / 18 / 91 \\
2 / 18 / 91\end{array}$ & $\begin{array}{l}18.15 \\
17.55 \\
17.05\end{array}$ & $\begin{array}{l}1,100 \mathrm{~g} \text { poly bag } \\
1,100 \mathrm{~g} \text { poly bag } \\
1,100 \mathrm{~g} \text { poly bag }\end{array}$ \\
\hline $\begin{array}{l}\text { TP03-12 } \\
\text { TP03-39 } \\
\text { TP03-72 }\end{array}$ & $\begin{array}{l}\text { Soil @ } 12 \\
\text { Soil @ } 39 \\
\text { Soil @ } 72\end{array}$ & $\begin{array}{l}2 / 19 / 91 \\
2 / 19 / 91 \\
2 / 19 / 91\end{array}$ & $\begin{array}{l}16.30 \\
16.50 \\
16.15\end{array}$ & $\begin{array}{l}1,100 \mathrm{~g} \text { poly bag } \\
1,100 \mathrm{~g} \text { poly bag } \\
1,100 \mathrm{~g} \text { poly bag }\end{array}$ \\
\hline $\begin{array}{l}\text { TP04-10 } \\
\text { TP04-22 } \\
\text { TP04-65 } \\
\text { TP04-W } \\
\text { TP04-W }\end{array}$ & $\begin{array}{l}\text { Soil @ } 10 \\
\text { Soil @ } 32 \\
\text { Soil @ 65 } \\
\text { Groundwater @ 65 } \\
\text { Groundwater @ 65 }\end{array}$ & $\begin{array}{l}2 / 20 / 91 \\
2 / 20 / 91 \\
2 / 20 / 91 \\
2 / 20 / 91 \\
2 / 20 / 91\end{array}$ & $\begin{array}{l}12.30 \\
12.40 \\
12.20 \\
11.40 \\
11.40\end{array}$ & $\begin{array}{l}1,100 \mathrm{~g} \text { poly bag } \\
1,100 \mathrm{~g} \text { poly bag } \\
1,100 \mathrm{~g} \text { poly bag } \\
2,40-\mathrm{mL} \text { I-VOA } \\
2,40-\mathrm{mL} \text { I-VOA }\end{array}$ \\
\hline
\end{tabular}

Analyze one (1) groundwater sample for the following constituents, characteristics:

$\mathrm{pH}$, Alkalinity, TDS, COD, TOC, TKN

$\mathrm{Fe}, \mathrm{Mn}, \mathrm{Na}, \mathrm{Ca}, \mathrm{K}, \mathrm{Zn}, \mathrm{B}, \mathrm{Mo}, \mathrm{NH} 4, \mathrm{Cl}, \mathrm{SO} 4, \mathrm{PO} 4, \mathrm{NO} 3$

RCRA metals (As, Ba, Cd, $\mathrm{Cr}, \mathrm{Pb}, \mathrm{Cu}, \mathrm{Hg}, \mathrm{Ag}$ )

Gross alpha and beta activity

TP04-W $\quad$ Groundwater @ $65 \quad 2 / 20 / 91 \quad 11.40 \quad 2,1-\mathrm{L}$ glass jars, 1, 0.5 L bottle

Analyze two (2) nutrient solution samples for the following constituents, characteristics:

$\mathrm{Fe}, \mathrm{Mn}, \mathrm{Na}, \mathrm{Ca}, \mathrm{K}, \mathrm{Zn}, \mathrm{B}, \mathrm{Mo}, \mathrm{NH} 4, \mathrm{Cl}, \mathrm{SO} 4, \mathrm{PO} 4, \mathrm{NO} 3$
NPK solution
nutrient solution
$2 / 21 / 91$
$1,40-\mathrm{mL}$ VOA vial
Micronutrient
nutrient solution
$2 / 21 / 91$
$1,12-\mathrm{mL}$ test tube

Notes:

Analytical methods: Use U.S. EPA approved methodologies. Provide citation with report. Maintain all unused sample at 40 C. Return all sample material and extracts to R.L. Siegrist. 
Table B.4. Inorganics Analysis Listing of Samples Returned to ORNL from Kwajalein Island on Saturday, March 2, 1991

\begin{tabular}{|c|c|c|c|c|}
\hline $\begin{array}{l}\text { Field sample } \\
\text { ID }\end{array}$ & $\begin{array}{c}\text { Sarnple } \\
\text { description }\end{array}$ & $\begin{array}{l}\text { Sample } \\
\text { date }\end{array}$ & $\begin{array}{l}\text { Sample } \\
\text { time }\end{array}$ & Containers \\
\hline $\begin{array}{l}\text { TP04-W } \\
\text { TP04-W } \\
\text { Analyze six (6) }\end{array}$ & $\begin{array}{r}\text { Groundwater@ @ } 65 \\
\text { Groundwater@65 } \\
\text { water samples for th } \\
\text { pH, Alkalinity, TD } \\
\text { Fe, Mn. Na, Ca, K } \\
\text { RCRA metals (As, }\end{array}$ & $\begin{array}{l}2 / 20 / 91 \\
2 / 20 / 91 \\
\text { wing const } \\
\text { D. TOC. T } \\
\text { Mo, NH4 } \\
\text { d, } \mathrm{Cr}, \mathrm{Pb}, \mathrm{C}\end{array}$ & $\begin{array}{l}\mathrm{SO} 4, \mathrm{PO} 4 \\
\mathrm{Ag})\end{array}$ & $\begin{array}{l}2,40-\mathrm{mL} \text { I-VOA } \\
2,40-\mathrm{mL} \text { I-VOA }\end{array}$ \\
\hline $\begin{array}{l}\text { ER218 } \\
\text { ER219 } \\
\text { ER220 } \\
\text { FB01 }\end{array}$ & $\begin{array}{l}\text { Equipment Blank } \\
\text { Equipment Blank } \\
\text { Equipment Blank } \\
\text { Field Blank }\end{array}$ & $\begin{array}{l}2 / 18 / 91 \\
2 / 19 / 91 \\
2 / 20 / 91 \\
2 / 19 / 91\end{array}$ & $\begin{array}{l}18.15 \\
18.15 \\
13.00 \\
16.45\end{array}$ & $\begin{array}{l}1,500 \mathrm{~mL}, 2,1-\mathrm{L} \text { jars } \\
1,500 \mathrm{~mL}, 2,1-\mathrm{L} \text { jars } \\
1,500 \mathrm{~mL}, 2,1-\mathrm{L} \text { jars } \\
2,1-\mathrm{L} \text { jars }\end{array}$ \\
\hline $\begin{array}{l}\text { TP01-W } \\
\text { TP03-W }\end{array}$ & $\begin{array}{l}\text { Groundwater@63 } \\
\text { Groundwater@63 }\end{array}$ & $\begin{array}{l}2 / 18 / 91 \\
2 / 19 / 91\end{array}$ & $\begin{array}{l}17.00 \\
16.30\end{array}$ & $\begin{array}{l}2,1-\mathrm{L} \text { glass jars, } 1,0.5 \mathrm{~L} \text { bottle } \\
2,1-\mathrm{L} \text { glass jars }\end{array}$ \\
\hline
\end{tabular}

Analyze four (4) nutrient solution samples for the following constituents, characteristics:

$\mathrm{Fe}, \mathrm{Mn}, \mathrm{Na}, \mathrm{Ca}, \mathrm{K}, \mathrm{Zn}, \mathrm{B}, \mathrm{Mo}, \mathrm{NH} 4, \mathrm{Cl}, \mathrm{SO} 4, \mathrm{PO} 4, \mathrm{NO} 3$

$\begin{array}{llll}\text { Macro 1X } & \text { NPK nutrient solution } & 3 / 15 / 91 & 75 \mathrm{~mL} \text { polybottle } \\ \text { Macro 10X } & \text { NPK nutrient solution } & 3 / 18 / 91 & 75 \mathrm{~mL} \text { polybottle } \\ \text { Micro 1X } & \text { Micronutrient solution } & 3 / 15 / 91 & 75 \mathrm{~mL} \text { polybottle } \\ \text { Micro 10X } & \text { Micronutrient solution } & 3 / 18 / 91 & 75 \mathrm{~mL} \text { polybottle }\end{array}$

Notes: $\quad$ Analytical methods: Use U.S. EPA approved methodologies. Provide citation with report. Maintain all unused sample at $4^{\circ} \mathrm{C}$. Return all sample material and extracts to R.L. Siegrist. 


\section{APPENDIX C \\ LABORATÓRY RESULTS FOR ORGANIC ANALYSES}




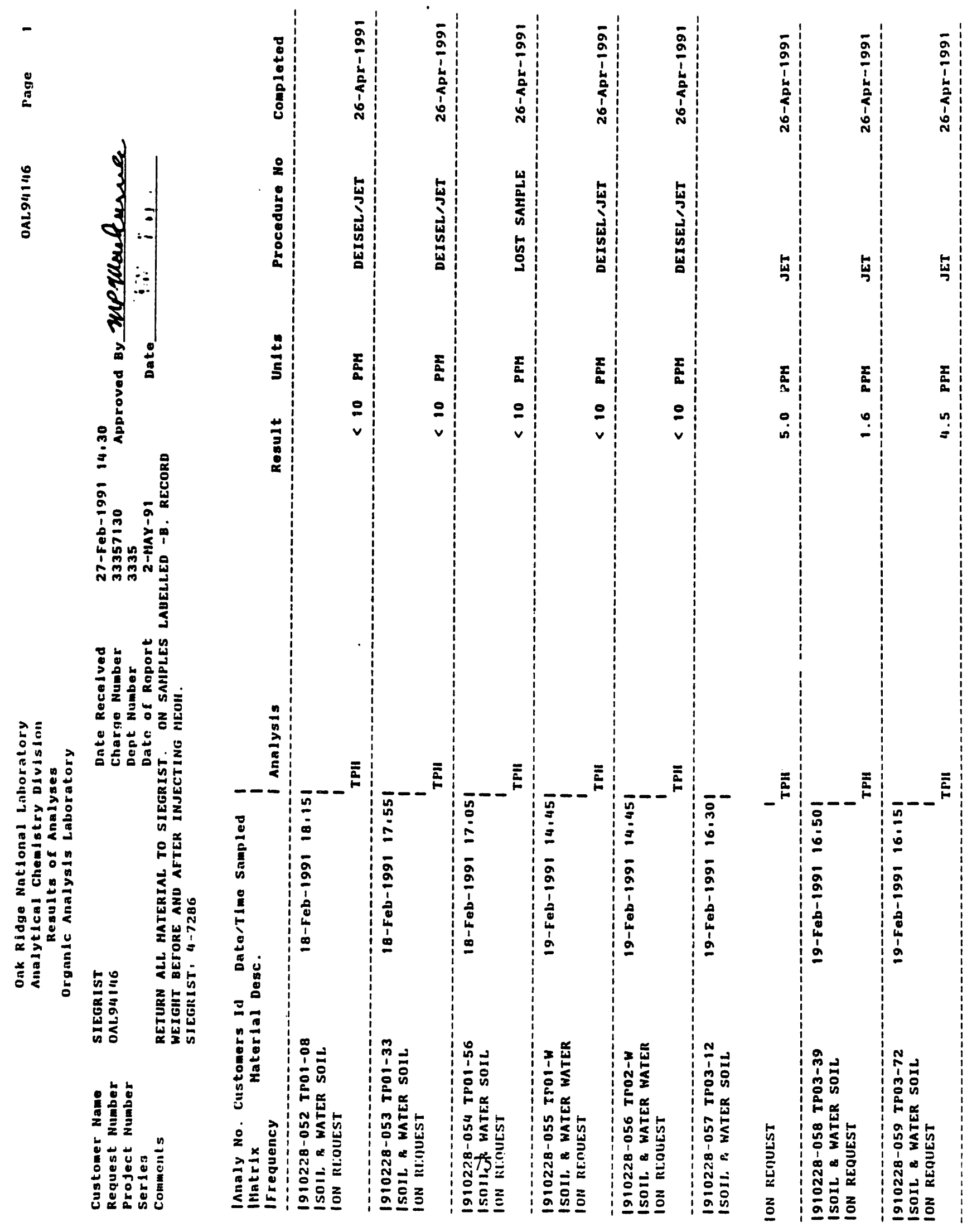




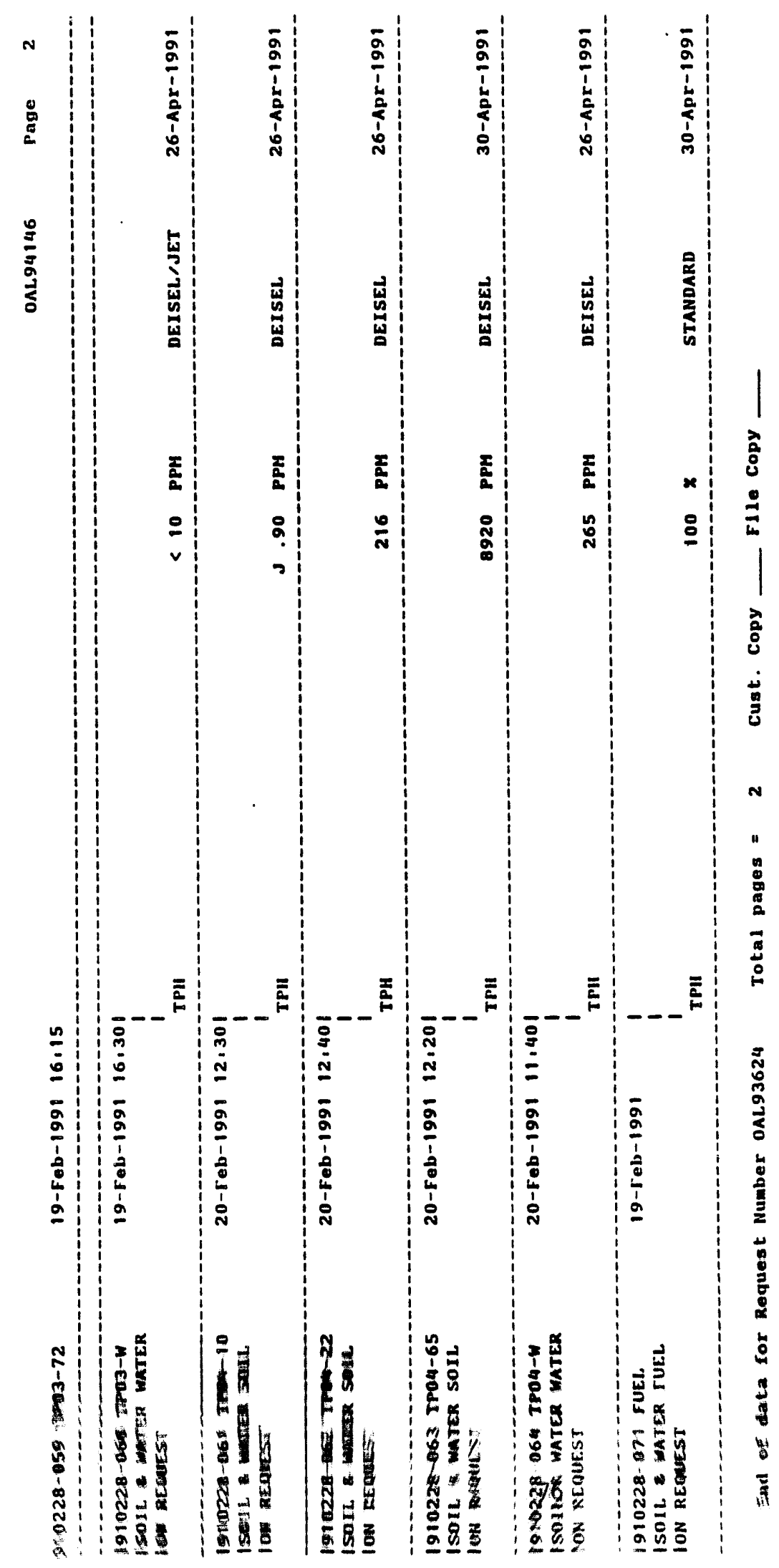




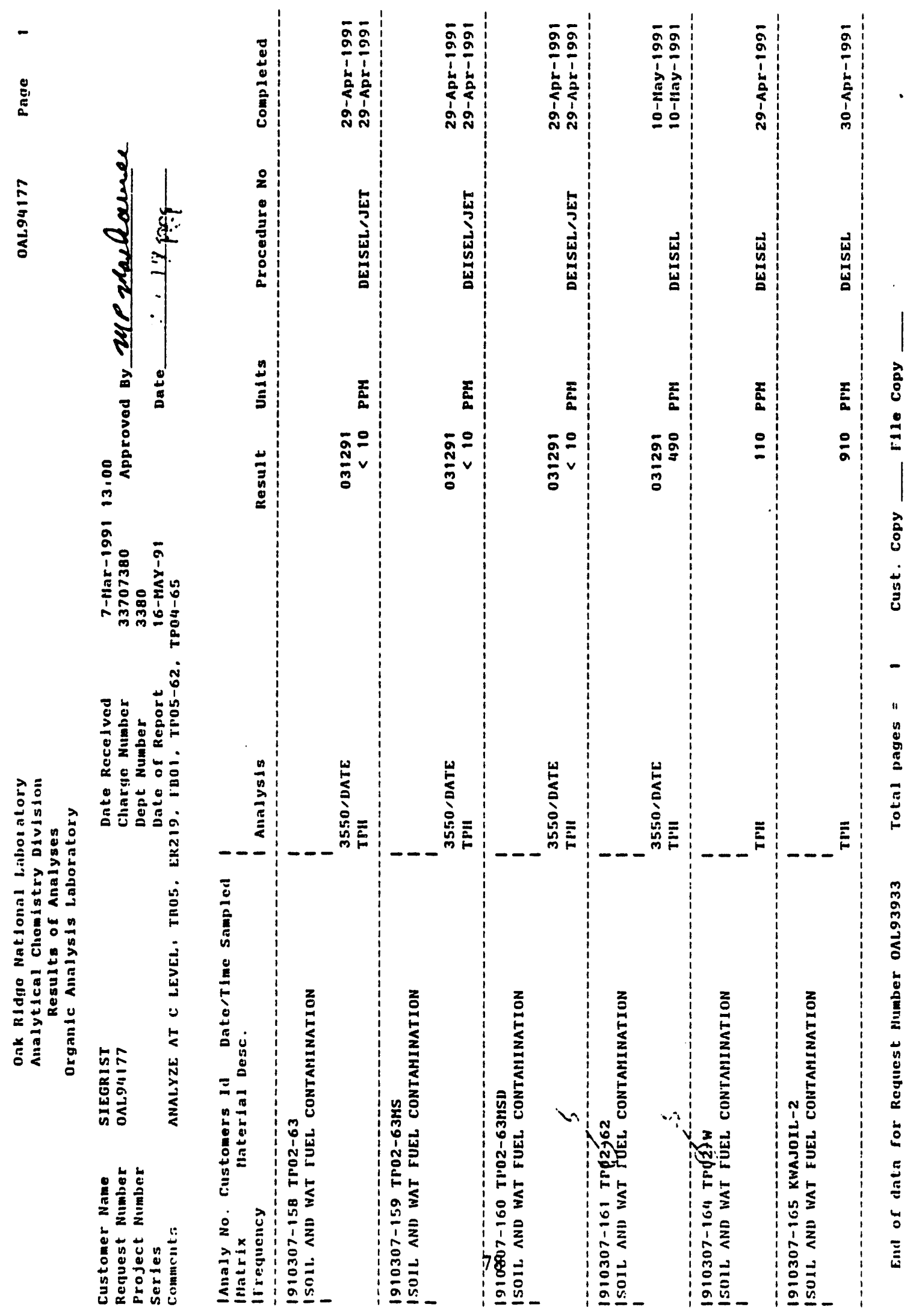




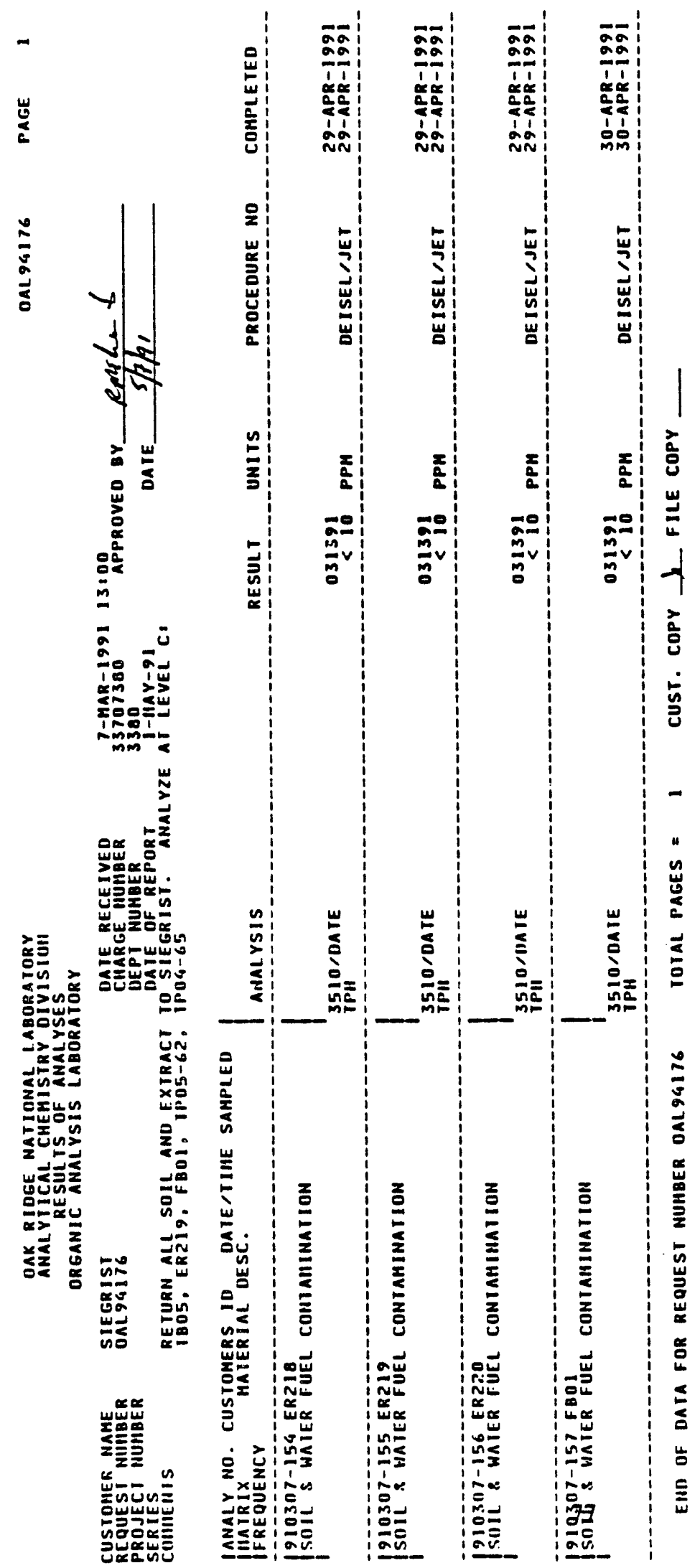


eOPLANATIOR OF DASA QOAITEIERS (Q)

Q

U

$\mathbf{J}$

B

$\mathbf{E}$

$\mathbf{x}$

\section{Explanation}

Indicates Compound was analyzed for but not detected. The sample quantitation limit is listed.

Indicates that the quantitative value is estimated. Usually this qualifier will appear aftor a value that is below the quantitation lintt, [1.e. the compound was datected, (at sone lovel below the quantitation limit)]. This qualifier any also appear after a tantativeiy Identifled compound (IIC) for which no specific calibration was avallable.

This qualifier appears for a compound that was datected In both the sample and Its associated blank.

This qualifier indlcates that the reported concentration of the compound axceeded the calibration range of the instrument.

This qualifier indicates 
Lab Name: Oak Ridge National Lab Lab code:

case no: ORNL

Matr1x: (so11/water) soIL

Sample wt/vol,

$5 \mathbf{G}$

Level: ( low/med) LoW

\% Moisture: not dec.

Column: (pack/cap) CAP contract, NR

SAS NO, NR

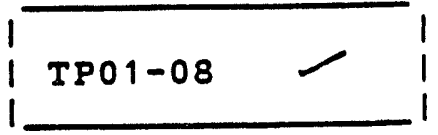

SDG NO: 0308
Lab Sample ID: 910228-052

Lab File ID: $\quad>01194$

Date Received 28-Feb-1991

Date Analyzed, 8-Mar-1991

Dilution Factor: 1.0 


\section{VOLATILE ORGANICS ANALYSIS DATA SHEET}

Request Number: OAL94146

EPA SAMPLE NO.

Procedure Number: 8240 Matrix, SOIL \& WATER

Series:

Frequency, ON REQUEST

Charge Number:

33357130

Customer Name: SIEGRIST

Sample wt/vol:

56

Date Sampled: 18-Feb-1991 18:15

\% Moisture, not dec.

dec:

Material Description SoIL

Number IICs found: 0
Lab Sample ID: 910228-052

Lab File ID: $>01194$

Date Recelved 27-Feb-1991 14:30

Date Analyzed: 8-Mar-1991

Date of Report: 2-MAY-91

CONCENTRATION UNITS:

(UG/L OI UG/KG) UG/KG

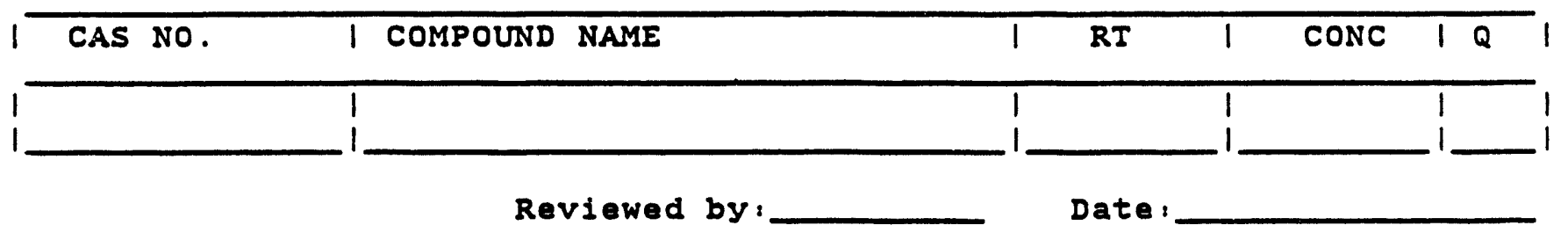


Semivolatile Organic Analysis Data

EPA SAMPLE NO.

Lab Name: Oak Ridge National Lab

Lab Code:

Case no: NR

Matrix: (soil/water) soIL

Sample wt/vol, $\quad 30.0 \mathrm{G}$

Level: ( low/med) Low

\% Molsture: not dec. dec.

Extraction: (sepf/Cont/Sonc) sonC

GPC Cleanup: $(Y / N) N \quad$ PH: NR
Contract, NR

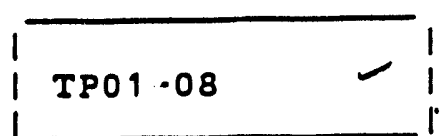

SAS NO: NR SDG NO: C319

Lab Sample ID: 910228-052

Lab File ID: >C3561

Date Received 28-Feb-1991

Date Analyzed: 19-Mar-1991

Date Extracted: 8-Mar-1991

Dilution Factor: $\quad 1.0$

CONCENTRATION UNITS:

CAS NO. COMPOUND (UG/L OI UG/XG) UG/KG

Q

\begin{tabular}{|c|c|c|c|c|}
\hline 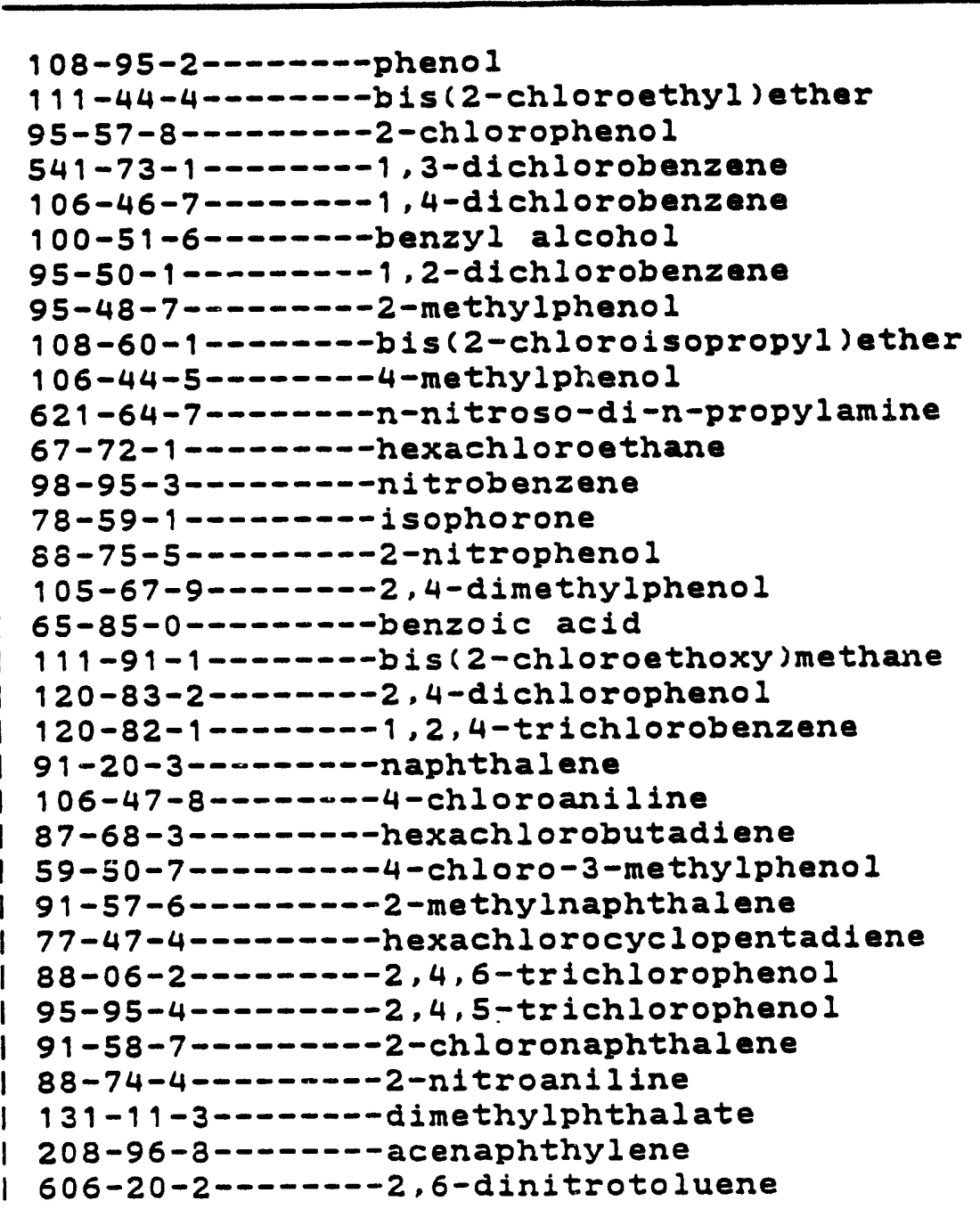 & $\begin{array}{l}1 \\
1 \\
1 \\
1 \\
1 \\
1 \\
1 \\
1 \\
1 \\
1 \\
1 \\
1 \\
1 \\
1 \\
1 \\
1 \\
1 \\
1 \\
1 \\
1 \\
1 \\
1 \\
1 \\
1 \\
1 \\
1 \\
1 \\
1 \\
1 \\
1 \\
1 \\
1\end{array}$ & $\begin{array}{r}330 . \\
330 . \\
330 . \\
330 . \\
330 . \\
330 . \\
330 . \\
330 . \\
330 . \\
330 . \\
330 . \\
330 . \\
330 . \\
330 . \\
330 . \\
330 . \\
1700 . \\
330 . \\
330 . \\
330 . \\
330 . \\
330 . \\
330 . \\
330 . \\
330 . \\
330 . \\
330 . \\
1700 . \\
330 . \\
1700 . \\
330 . \\
330 . \\
330 .\end{array}$ & $\begin{array}{l}1 \\
1 \\
1 \\
1 \\
1 \\
1 \\
1 \\
1 \\
1 \\
1 \\
1 \\
1 \\
1 \\
1 \\
1 \\
1 \\
1 \\
1 \\
1 \\
1 \\
1 \\
1 \\
1 \\
1 \\
1 \\
1 \\
1 \\
1 \\
1 \\
1 \\
1 \\
1 \\
1 \\
1\end{array}$ & $\begin{array}{l}U \\
U \\
U \\
U \\
U \\
U \\
U \\
U \\
U \\
U \\
U \\
U \\
U \\
U \\
U \\
U \\
U \\
U \\
U \\
U \\
U \\
U \\
U \\
U \\
U \\
U \\
U \\
U \\
U \\
U \\
U \\
U \\
U\end{array}$ \\
\hline
\end{tabular}


Semivolatile organic Analysis Data

Lab Name: Oak Ridge National Lab

Lab code:

Case no: NR

Matrix: (soil/water) soIL

Sample wt/vol: $\quad 30.0 \mathrm{G}$

Level: (low/med) LOW

\% Moisture: not dec. dec.

Extraction: (Sepf/Cont/sone) soNC GPC Cleanup: $(Y / N)$ N PH : NR
Contract: NR
EPA SAMPLE NO.

$$
\text { TP01-08 }
$$

SAS NO: NR
SDG NO: C319

Lab Sample ID: 910228-052

Lab File ID: $\quad>C 3561$

Date Received 28-Feb-1991

Date Aralyzed: 19-Mar-1991

Date Extracted: 8-Mar-1991

Dilution Factor: $\quad 1.0$

CONCENTRATION UNITS :

CAS NO.

COMPOUND

1700 .

630 .

66.

1300 .

930 .

820.

330 .

670 .

370 .

510.

330 .

330 .

330 .

330 .

400 .

330 .

330 .

330 . Q

(i) - Cansot be separated from Diphenylamine 
Semivolatile organic Analysis Data

Request Number: OAL94146

Procedure Number: 8240 Matrix: SOIL \& WATER

EPA SAMPLE NO.

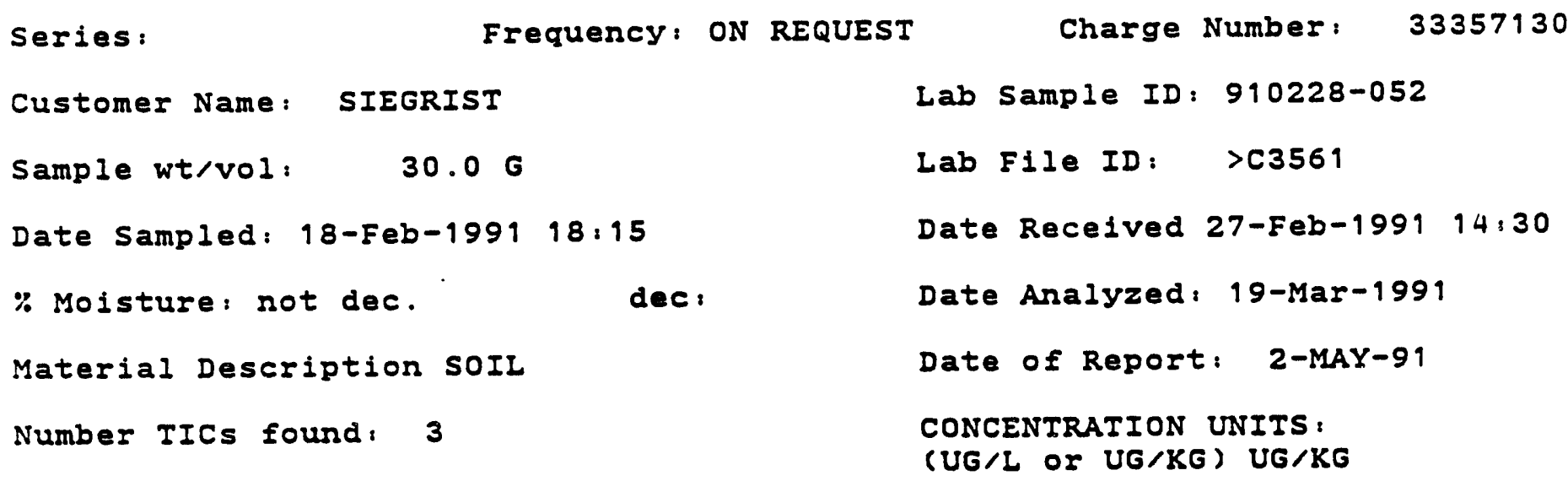

\begin{tabular}{|c|c|c|c|c|c|c|}
\hline CAS NO. & I COMPOUND NAME & RT & 1 & CONC & & $Q$ \\
\hline $\begin{array}{l}1 . \\
2 . \\
3 .\end{array}$ & $\begin{array}{l}\text { ITOLUENE-SOLVENT IN STD SOLNS } \\
\text { I UNKNOWN } \\
\text { IETHANE } 1,1,2,2 \text {-TETRACHLORO- }\end{array}$ & $\begin{array}{r}7.22 \\
10.26 \\
11.40\end{array}$ & $\begin{array}{l}1 \\
1 \\
1 \\
1\end{array}$ & $\begin{array}{l}270 . \\
140 . \\
210 .\end{array}$ & $\begin{array}{l}1 \\
1 \\
1 \\
1\end{array}$ & $\begin{array}{l}J B \\
J B \\
J B\end{array}$ \\
\hline
\end{tabular}

Reviewed by:

Date : 
Lab Name: Oak Ridge National Lab Lab Code: Case no: ORNL

Matrix: (soil/water) soIL

Sample wt/vol:

$5 \mathbf{G}$

Level: ( low/med) LOW

\% Moisture: not dec.

Column: (pack/cap) CAP
Contract, NR

SAS NO: NR

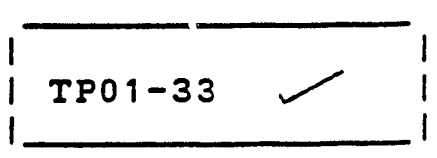

SDG NO: 0308
Lab sample ID: 910228-053

Lab File ID: $\quad>01195$

Date Received 28-Feb-1991

Date Analyzed: 8-Mar-1991

Dilution Factor: $\quad 1.0$

CAS NO.

COMPOUND

CONCENTRATION UNITS: (UG/L UT UG/KG) UG/KG

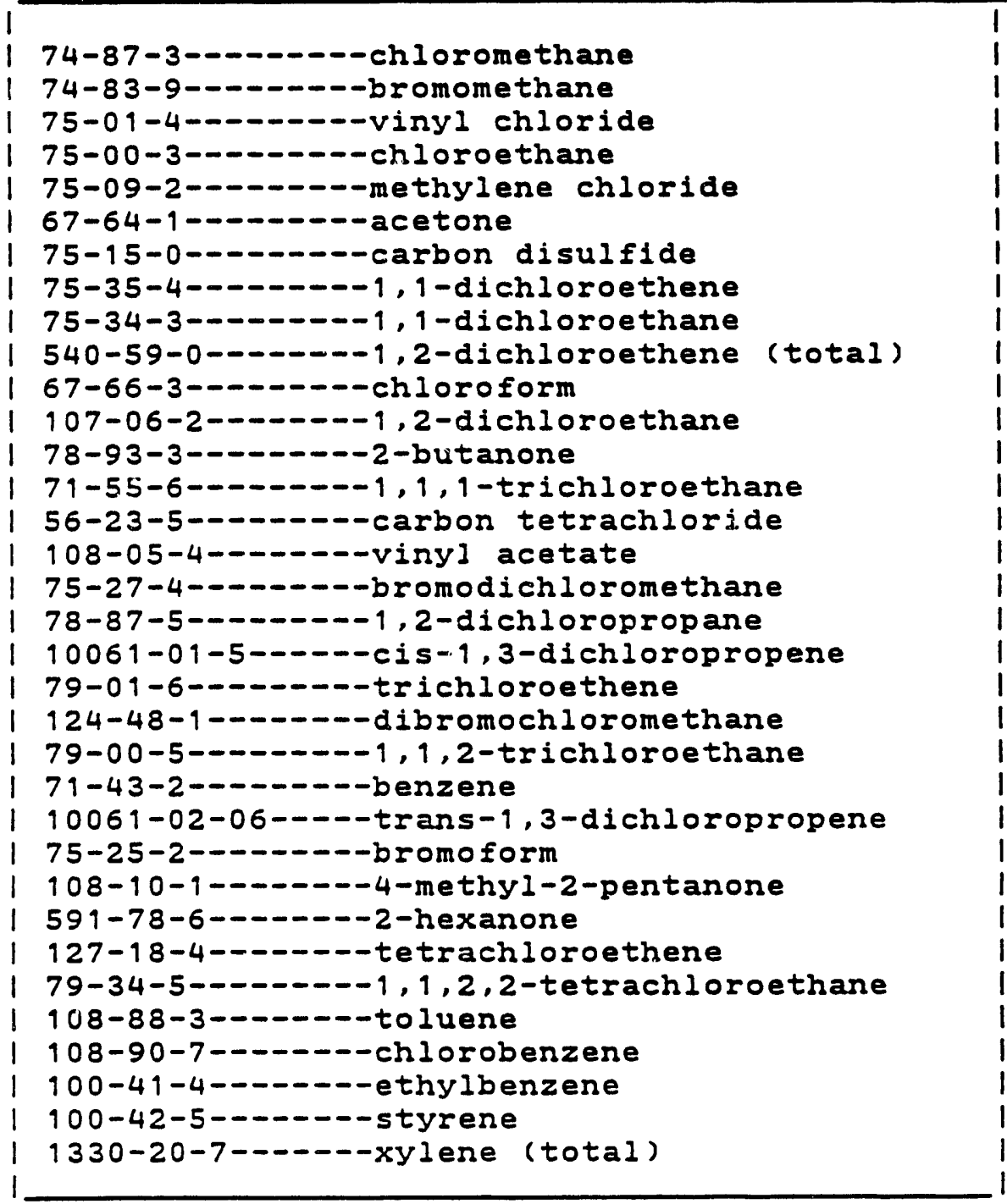


Semivolatile Organic Analysis Data

EPA SAMPLE NO.

Lab Name: Oak Ridge National Lab

Lab Code:

Case no: NR

Matrix: (soil/water) soIL

Sample wt/vol: $\quad 30.6 \mathrm{G}$

Level: ( low/med) Low

\% Moisture: not dec. dec.

Extraction: (sepf/Cont/sonc) sonc

GPC CIr:asup: $(Y / N) N \quad$ PH: NR
Contract: NR
TP01-33

SAS NO: NR SDG NO: C319

Lab Sample ID: 910228-053

Lab File ID: $\quad>C 3562$

Date Received 28-Feb-1991

Date Aralyzed: 19-Mar-1991

Date Extracted: 8-Mar-1991

Dilution Factor: $\quad 1.0$

CONCENTRATION UNITS:

CAS NO. COMPOUND (UG/L OI UG/KG) UG/KG

330 .

330 .

330 .

330 .

330 .

330 .

330 .

330 .

330 .

330 .

330 .

330 .

330 .

330 .

330 .

330 .

1600 .

330 .

330 .

330 .

330 .

330 .

330 .

330 .

330 .

330 .

330 .

9600 .

330 .

1600 .

330 .

330 .

330 . 
Semivolatile Organic Analysis Data

EPA SAMPLE NO.

Lab Name: Oak Ridge National Lab

Lab Code:

Case no: NR

Matrix: (soil/water) soIL

Sample wt/vol: $\quad 30.6 \mathrm{G}$

Level: (low/med) Low

\% Moisture: not dec. dec.

Extraction: (Sepf/Cont/Sonc) soNC

GPC Cleanup: $(Y / N)$ N $p H: \quad N R$
Contract: NR

SAS NO: NR

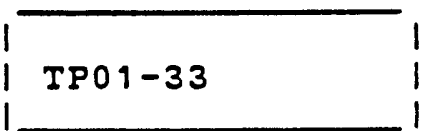

SDG NO: C319

Lab Sample ID: 910228-053

Lab File ID: >C3562

Date Received 28-Feb-1991

Date Analyzed: 19-Mar-1991

Date Extracted: 8-Mar-1991

Dilution Factor: $\quad 1.0$

CONCENTRATION UNITS:

CAS NO.

COMPOUND

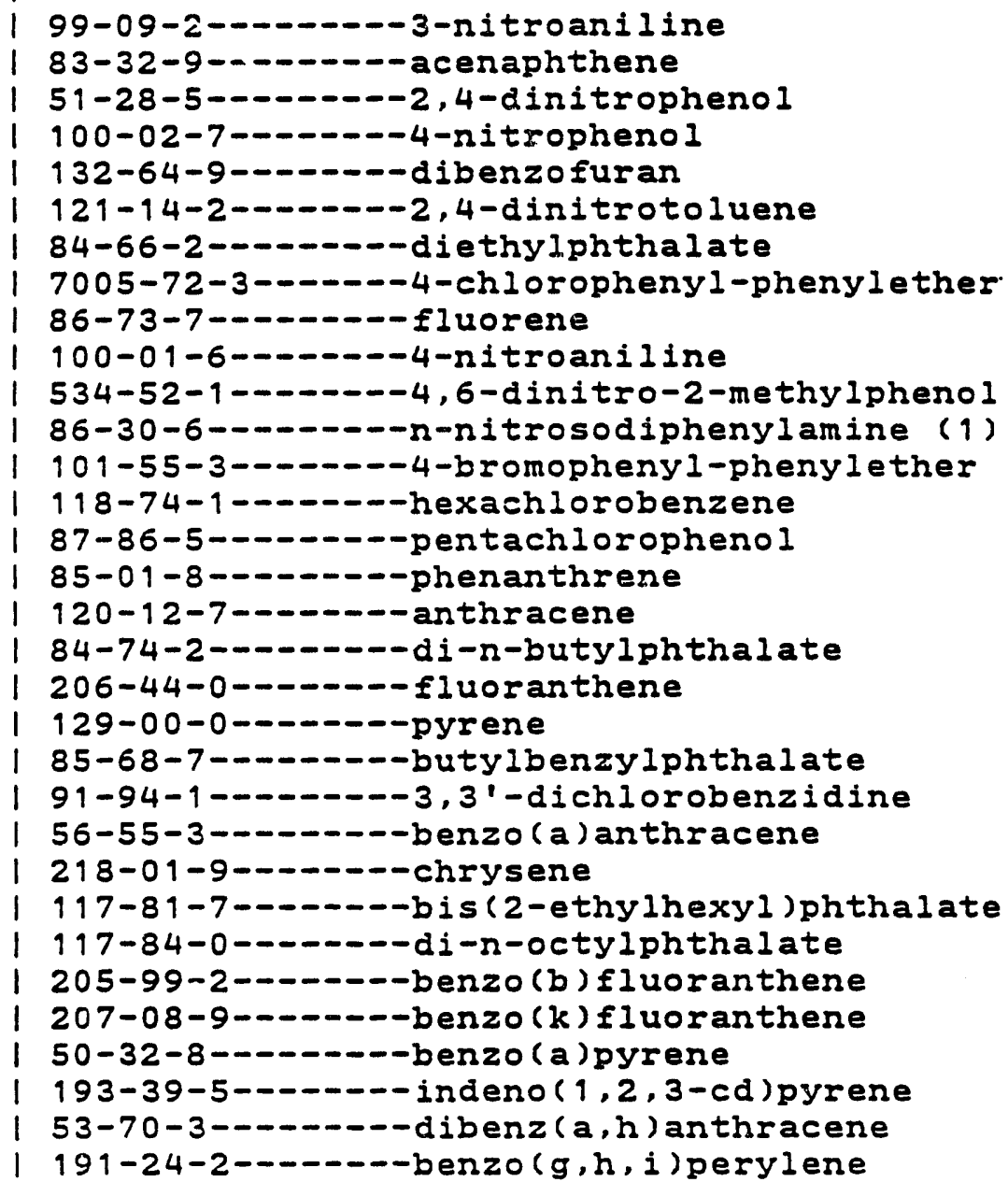




\section{Semivolatile Organic Analysis Data}

Request Number: OAL94146

EPA SAMPLE NO.

Procedure Number: 8240

Matrix: SOIL \& WATER

\section{Series:}

Frequency: ON REQUEST

Charge Number: $\quad 33357130$

Customer Name: SIEGRIST

Sample wt/vol: $\quad 30.6 \mathrm{G}$

Date Sampled: 18-Feb-1991 17:55

x Moisture: not dec.

Material Description SOIL

Number IICs found: 4
Lab Sample ID: 910228-053

Lab File ID: $\quad>C 3562$

Date Received 27-Feb-1991 14:30

dec :

Date Analyzed: 19-Mar-1991

Date of Report: 2-MAY-91

CONCENTRATION UNITS :

(UG/L or UG/KG) UG/KG

\begin{tabular}{ll}
\hline CAS NO. & I COMPOUND NAME \\
\hline 1. & I IOLUENE-SOLVENT IN STD SOLNS \\
12. & IUNKNOWN \\
3. & IUNKNOWN \\
4. & IETHANE, 1,9,2,2-TETRACHLORO- \\
\hline
\end{tabular}

Reviewed by:
Date: 
Lab Name: Oak Ridge National Lab Lab Code:

Case no: ORNL

Matrix: (soil/water) soIl

Sample wt/vol:

5 G

Level: (low/med) LOW

\% Moisture: not dec.

Column: (pack/cap) PACK
Contract: NR

SAS NO: NR

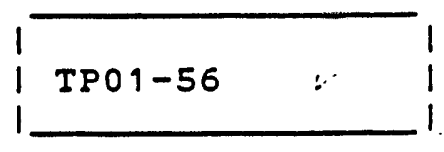

SDG NO: 6304
Lab Sample ID: 910228-054

Lab File ID: $\quad>$ G2139

Date Received 28-Feb-1991

Date Analyzed: 4-Mar-1991

Dilution Factor: $\quad 1.0$

CAS NO.

COMPOUND

CONCENTRATION UNITS:

(UG/L or UG/KG) UG/KG

Q

\begin{tabular}{|c|}
\hline 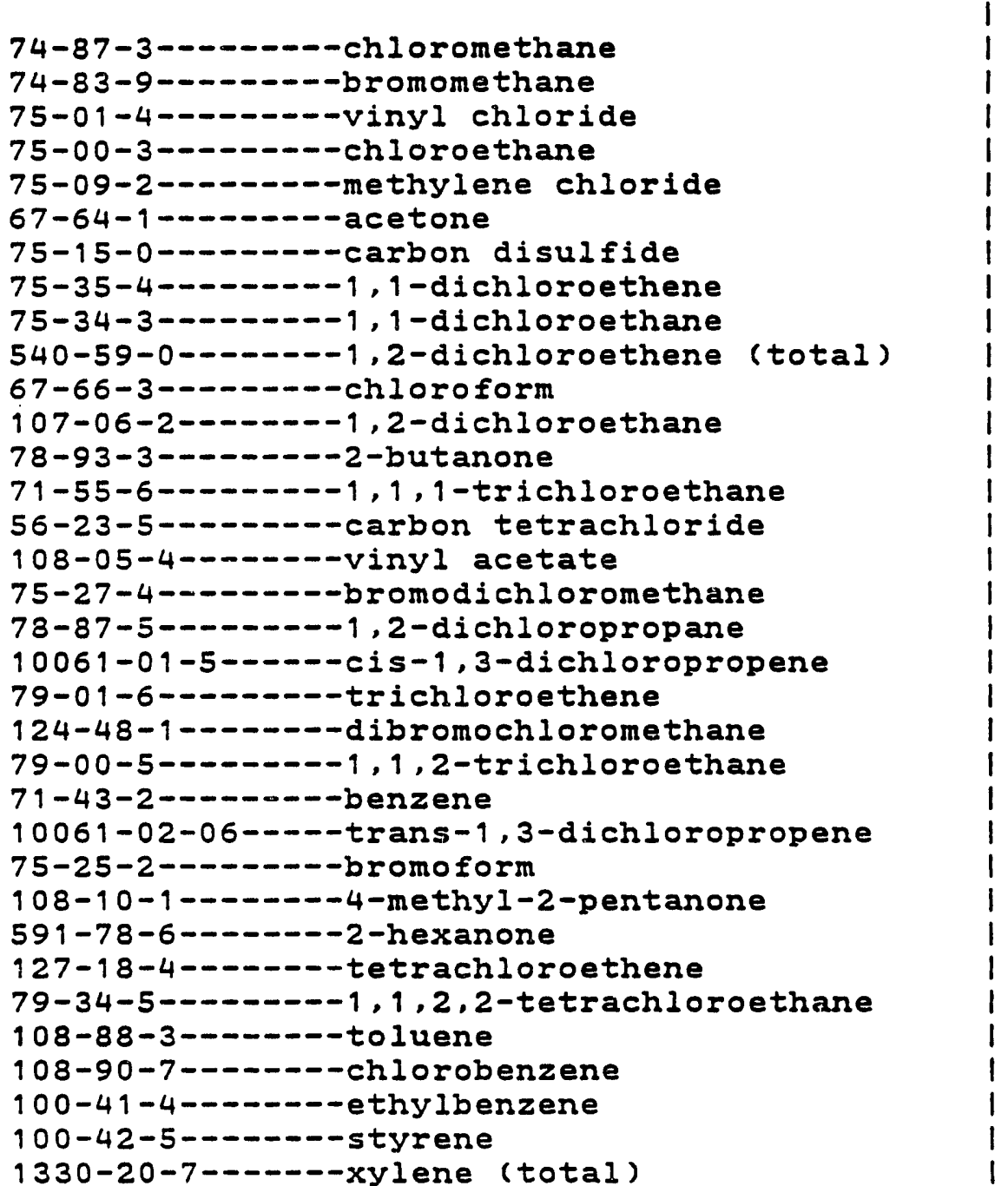 \\
\hline
\end{tabular}

Reviewed by:

\begin{tabular}{|c|c|c|}
\hline 10. & 1 & U \\
\hline 10. & 1 & $U$ \\
\hline 10. & 1 & $U$ \\
\hline 10. & 1 & $U$ \\
\hline 5.00 & 1 & $U$ \\
\hline 10. & 1 & $U$ \\
\hline 5.00 & 1 & $U$ \\
\hline 5.00 & 1 & $U$ \\
\hline 5.00 & 1 & $U$ \\
\hline 5.00 & 1 & $U$ \\
\hline 5.00 & 1 & $U$ \\
\hline 5.00 & 1 & $U$ \\
\hline 10. & 1 & $\mathrm{U}$ \\
\hline 5.00 & 1 & $U$ \\
\hline 5.00 & 1 & $U$ \\
\hline 10. & 1 & $U$ \\
\hline 5.00 & 1 & $U$ \\
\hline 5.00 & 1 & $U$ \\
\hline 5.00 & 1 & $U$ \\
\hline 5.00 & 1 & $U$ \\
\hline 5.00 & 1 & $U$ \\
\hline 5.00 & 1 & $U$ \\
\hline 5.00 & 1 & $U$ \\
\hline 5.00 & 1 & $U$ \\
\hline 5.00 & 1 & $U$ \\
\hline 10. & 1 & $U$ \\
\hline 10. & 1 & $U$ \\
\hline 5.00 & 1 & U \\
\hline 5.00 & 1 & $U$ \\
\hline 5.00 & 1 & $U$ \\
\hline 5.00 & 1 & $U$ \\
\hline 5.00 & 1 & $U$ \\
\hline 5.00 & 1 & U \\
\hline 5.00 & 1 & U \\
\hline
\end{tabular}

Date : 


\section{VOLATILE ORGANICS ANALYSIS DAIA SHEET}

Request Number: OAI94146

Procedure Number: 8240

Matrix: SOIL \& WATER
EPA SAMPLE NO.

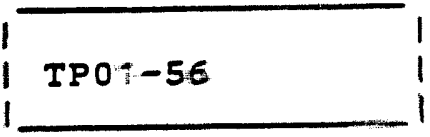

ON REQUEST Charge Numbe: 33357130
Customer Name: SIEGRIST

Sample wt/vol:

5 G

Date Sampled: 18-Feb-1991 17:05

\% Moisture: not dec.

dec:

Material Description SOIL

Number IICs found: 0
Lab Sample ID: 910228-054

Lab File ID: $>62139$

Date Received 27-F-1991 $14: 30$

Date Malyzed: 4-Mar-1991

Date of Report: 2-MAY-91

CONCENTRATION UNITS, (UG/L Or UG/KG) UG/KG

\begin{tabular}{|c|c|c|c|c|c|c|}
\hline CAS NO. & I COMPOUND NAME & 1 & $\mathbf{R T}$ & 1 & CONC & IQ \\
\hline & 1 & 1 & & 1 & & 1 \\
\hline
\end{tabular}


Lab Name: Oak Ridge National Lab

Lab Code:

Case no: ORNL

Matrix: (soil/water) WATER

Sample wt/vol: 5 ML

Level: (lon/med) LOW

\% Moisture: not dec.

Colums: (pack/cap) PACK
Contract: NR

SAS NO: NR

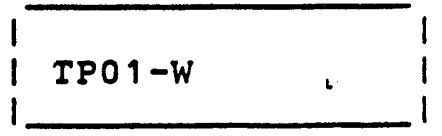

SDG NO: 6228
Lab Sample ID: 910228-055

Lab File ID: $\quad>62109$

Dats Received 28-Feb-1991

Date Analyzed: 28-Feb-1991

Dilution Factor: $\quad 1.0$

CAS NO.

COMPOUND

CONCENTRATION UNITS:

(UG/L or UG/KG) UG/L

Q

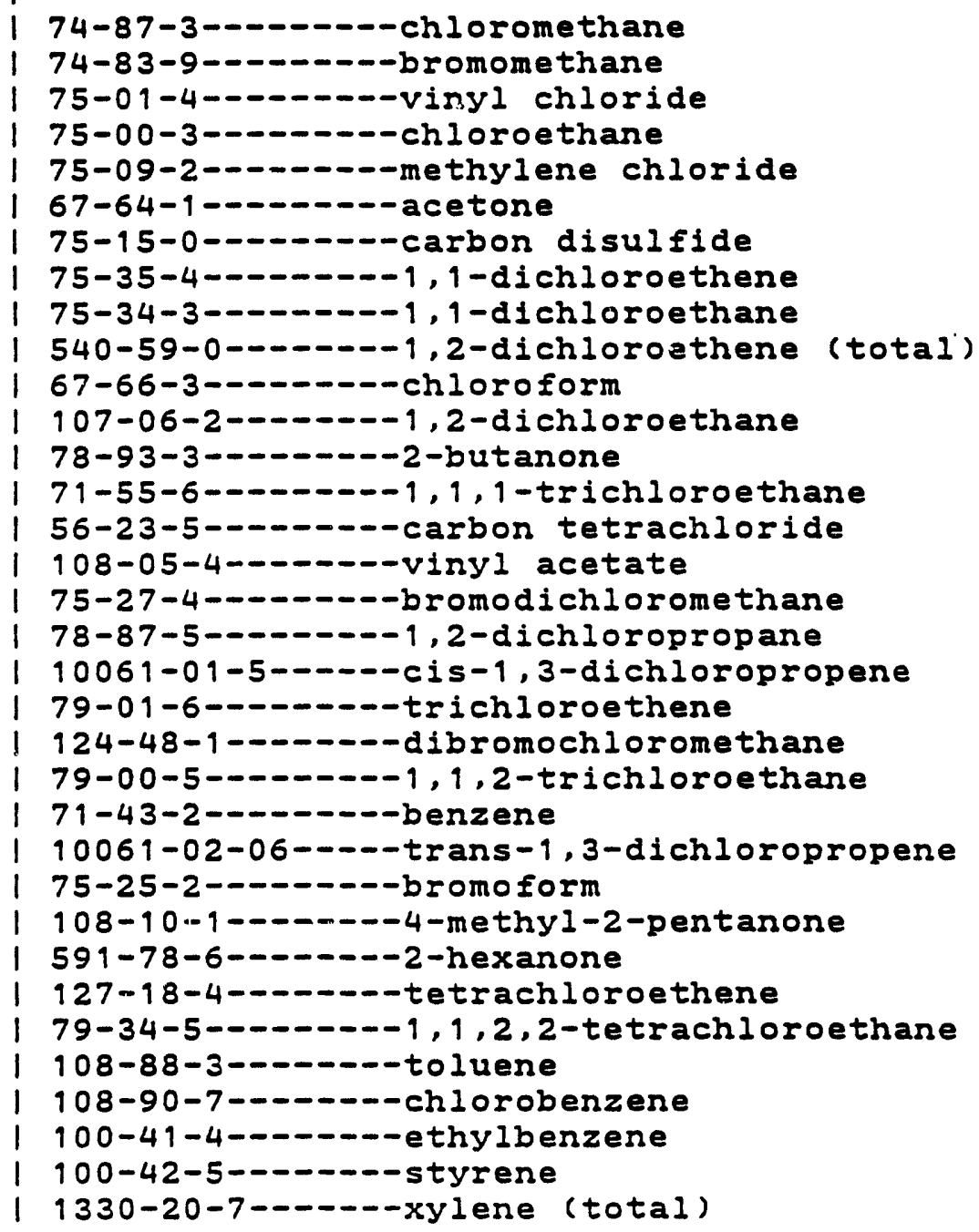

\begin{tabular}{|c|c|c|c|c|}
\hline & 1 & & 1 & \\
\hline & 1 & 10. & 1 & U \\
\hline & 1 & 10. & 1 & $U$ \\
\hline & 1 & 10. & 1 & $U$ \\
\hline & 1 & 10. & 1 & $U$ \\
\hline & 1 & 5.00 & 1 & $U$ \\
\hline & 1 & 10 & 1 & $U$ \\
\hline & 1 & 5.00 & 1 & $U$ \\
\hline & 1 & 5.00 & 1 & $U$ \\
\hline & 1 & 5.00 & 1 & $U$ \\
\hline total) & 1 & 5.00 & 1 & $U$ \\
\hline & 1 & 5.00 & 1 & $U$ \\
\hline & 1 & 5.00 & 1 & $U$ \\
\hline & 1 & 10. & 1 & U \\
\hline & 1 & 5.00 & 1 & $U$ \\
\hline & 1 & 5.00 & 1 & $U$ \\
\hline & 1 & 10. & 1 & $U$ \\
\hline & 1 & 5.00 & 1 & $U$ \\
\hline & 1 & 5.00 & 1 & $U$ \\
\hline ene & 1 & 5.00 & 1 & $U$ \\
\hline & 1 & 5.00 & 1 & $U$ \\
\hline & 1 & 5.00 & 1 & $U$ \\
\hline & 1 & 5.00 & 1 & $U$ \\
\hline & 1 & 5.00 & 1 & $U$ \\
\hline opere & 1 & 5.00 & 1 & $U$ \\
\hline & 1 & 5.00 & 1 & $U$ \\
\hline & 1 & 10 & 1 & U \\
\hline & 1 & 10. & 1 & $U$ \\
\hline & 1 & 5.00 & 1 & $U$ \\
\hline thane & 1 & 5.00 & 1 & U \\
\hline & 1 & 5.00 & 1 & $U$ \\
\hline & 1 & 5.00 & 1 & $U$ \\
\hline & 1 & 5.00 & 1 & $U$ \\
\hline & 1 & 5.00 & 1 & $U$ \\
\hline & 1 & 5.00 & 1 & U \\
\hline
\end{tabular}

Reviewed by: 


\section{VOLATILE ORGANICS ANALYSIS DATA SHEET}

Request Number: OAL 94146

Procedure Number: 8240

Matrix: SOIL \& WATER

Series:

Frequency: ON REQUEST

Charge Number:

33357130

Customer Name: SIEGRIST

Sample wt/vol:

5 ML

Date Sampled: 19-Feb-1991 14:45

\% Moisture: not dec.

dec:

Material Description WATER

Number TICs found: 0
EPA SAMPLE NO.

TP01-W
Lab Sample ID: 910228-055

Lab File ID: >G2109

Date Received 27-Feb-1991 14:30

Date Analyzed: 28-Feb-1991

Date of Report: 2-MAY-91

CONCENTRATION UNITS:

TICs found 0 (UG/L OY UG/KG) UG/L

\begin{tabular}{|c|c|c|c|c|c|}
\hline CAS NO. & I COMPOUND NAME & RT & 1 & CONC & 10 \\
\hline 1 & 1 & 1 & 1 & & 1 \\
\hline
\end{tabular}


Lab Name: Oak Ridge National Lab Contract: NR

Lab Code: Case no: CLP. SAS No: NR SDG No: C425

Lab Code: Case no: CLP. SAS No: NR SDG No: C425

Matrix: (soil/water) WATER

Sample wt/vol: $165 \mathrm{ML}$

Level: (low/med) Low

\% Moisture: not dec. dec.

Extraction: (Sepf/Cont/Sonc) SEPF

GPC Cleanup: $(Y / N) N$

$\mathrm{pH}: 8.83$
Lab Sample ID: 910228-055

Lab File ID: >C3764

Date Received 28-Feb-1991

Date Analyzed: 25-Apr-1991

Date Extracted: 18-Mar-1991

Dilution Factor: 6.1 CAS NO. COMPOUND (UG/L OS UG/KG) UG/L

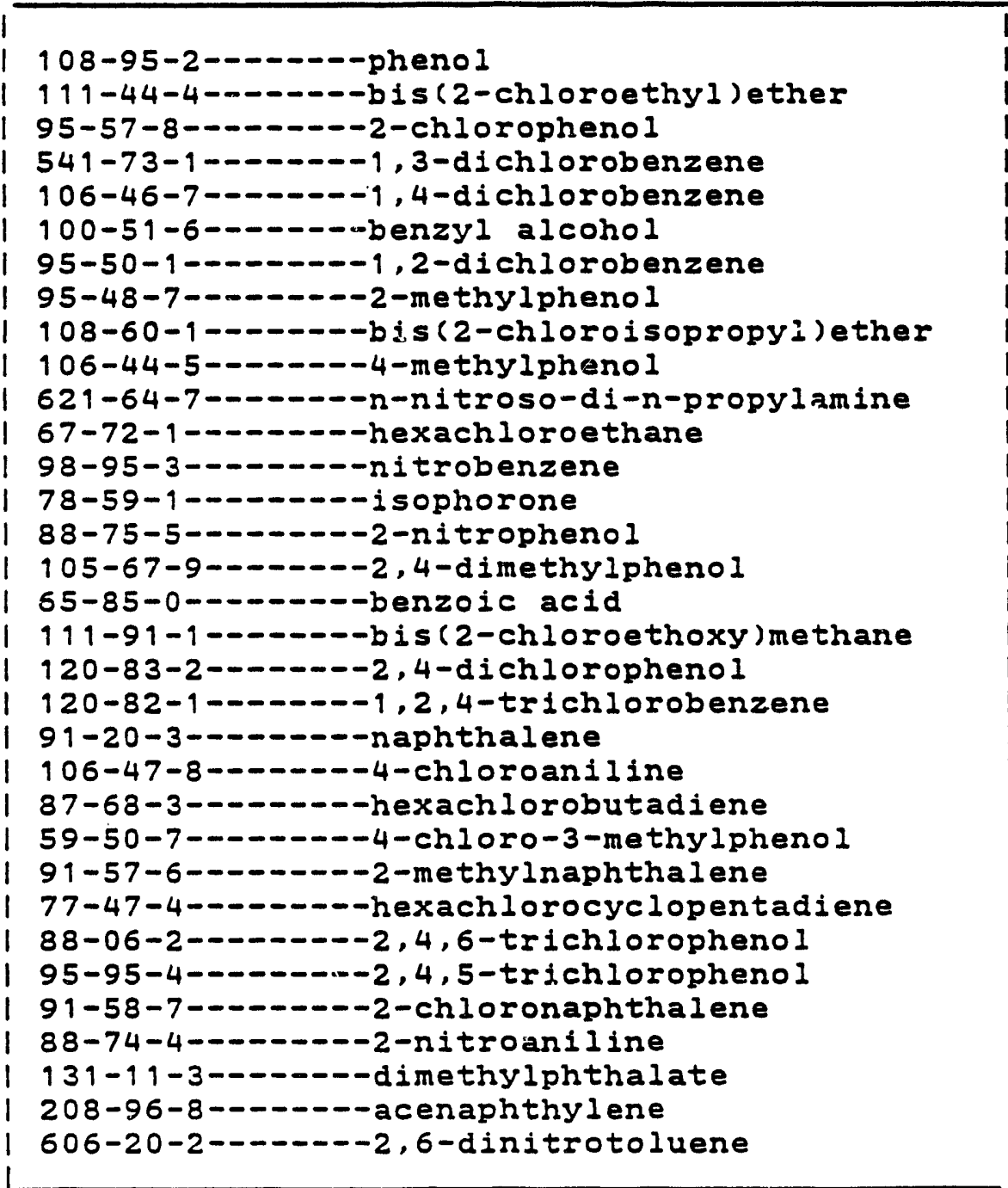

61.

61.

61.

61.

61.

61.

61.

61.

61.

61.

61.

61.

61.

61.

61.

61.

300 .

61.

61.

61.

61.

61.

61.

61.

61.

61.

61.

300.

61.

300 .

61.

61.

61. 
Semivolatile Organic Analysis Data

Lab Name: Oak Ridge National Lab Contract, NR

Lab Code:

Case no: CLP

Matrix: (sol1/water) WATER

Sample wt/vol: $165 \mathrm{ML}$

Leve1: (low/med) Low

\% Moisture, not dec. dec.

Extraction: (Sepf/Cont/Sonc) SEPF

GPC Cleasup: $(Y / N)$ N

$\mathrm{pH}: 8.83$
SAS NO: NR
I TPO1-W

SDG NO: C425

Lab Sample ID: 910228-055

Lab File ID: $>C 3764$

Date Received 28-Feb-1991

Date Analyzed: 25-Apr-1991

Date Extracted: 18-Mar-1991

Dilution Factor: $\quad 6.1$

CAS NO. COMPOUND (UG/L OY UG/KG) UG/L

Q

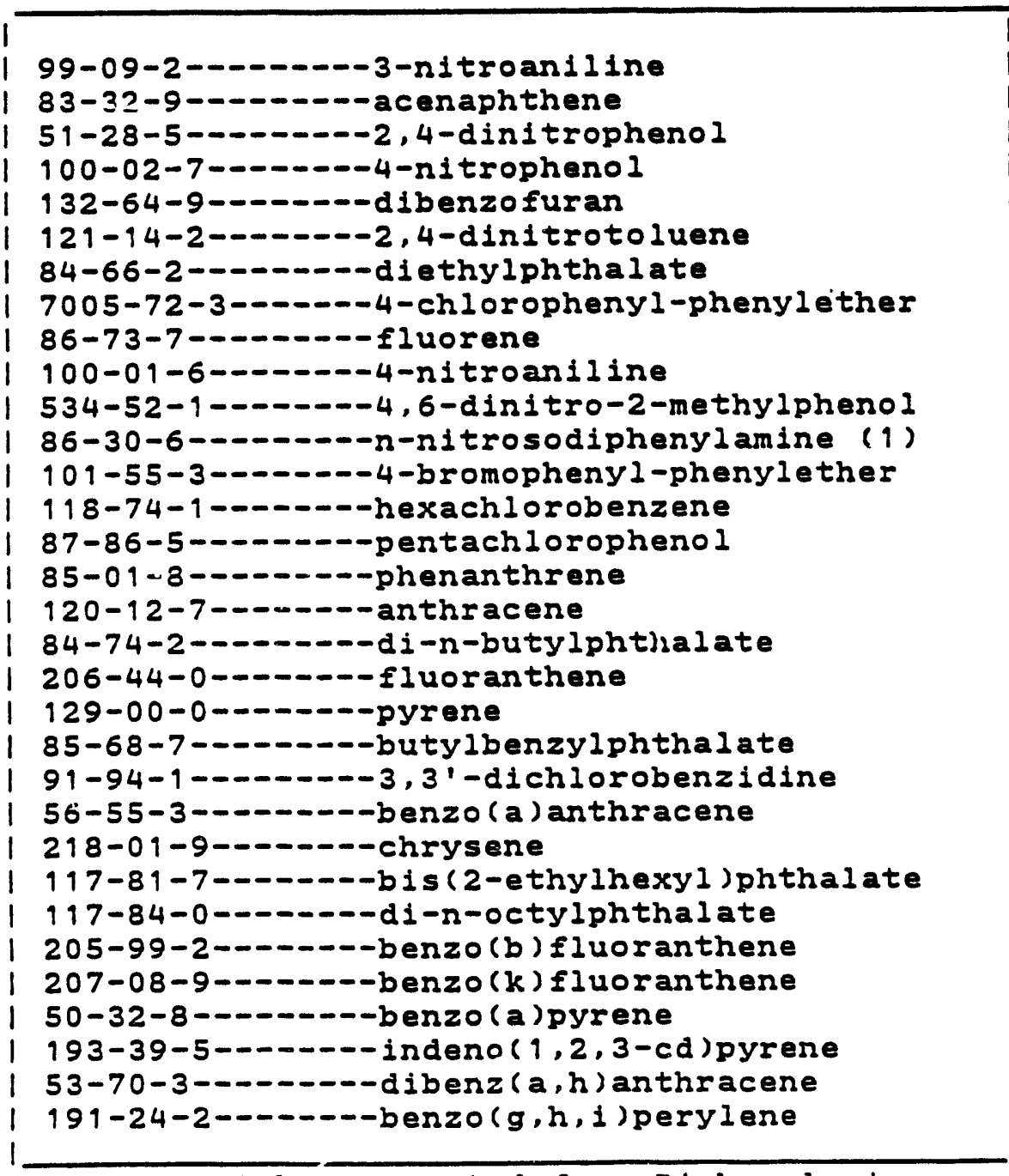

(1) - Cannot be separated from Diphenylanine
300

61 .

300.

300 .

61.

61.

61.

61.

61.

300 .

300 .

61.

61.

61.

300 .

61 .

61.

61.

61.

61.

120.

120 .

61.

61.

61.

61.

61.

61.

61.

61.

61.

61 . 


\section{Semivolatile organic Analysis Data}

Request Number: OAL 94146

Procedure Number: 8240 Matrix: SOIL \& WATER

Series:

Frequency: ON REQUEST

Charge Number:

33357130

Customer Name: SIEGRIST

Sample wt/vol: $165 \mathrm{ML}$

Date Sampled: 19-Feb-1991 14:45

$\because$ Moisture: not dec.

dec:

Material Description WATER

Number IICs found: 0
Lab Sample ID: 910228-055

Lab File ID: >C3764

Date Received 27-Feb-1991 14:30

Date Analyzed: 25-Apr-1991

Date of Report: 2-MAY-91

CONCENTRATION UNITS: (UG/L OY UG/KG) UG/L

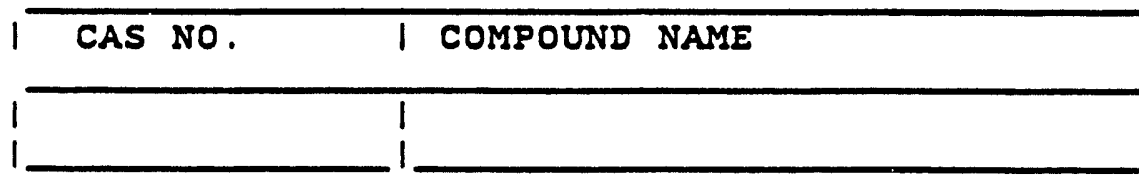

Reviewed by

\begin{tabular}{llllll}
\hline & RT & I CONC I
\end{tabular}

i

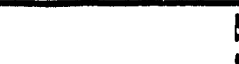

!

Date: 


\section{VOLATILE ORGANICS ANALYSIS DATA SHEET}

EPA SAMPLE NO.

Lab Name: Oak Ridge National Lab Lab Code:

Case no: ORNL

Matr1x: (so11/water) WATER

Sample wt/vol,

$5 \mathrm{ML}$

Level: (low/med) LoW

\% Moisture: not dec.

Column: (pack/cap) PACK
Contract: NR

SAS NO: NR

\section{TP02-W}

SDG NO: 6228

Lab Sample ID: $910228-056$

Lab F1le ID: $\quad>$ G2110

Date Received 28-Feb-1991

Date Analyzed: 28-Feb-1991

Dilution Factor: $\quad 1.0$

CONCENTRATION UNITS:

CAS NO. COMPOUND (UG/L OY UG/KG) UG/L

Q

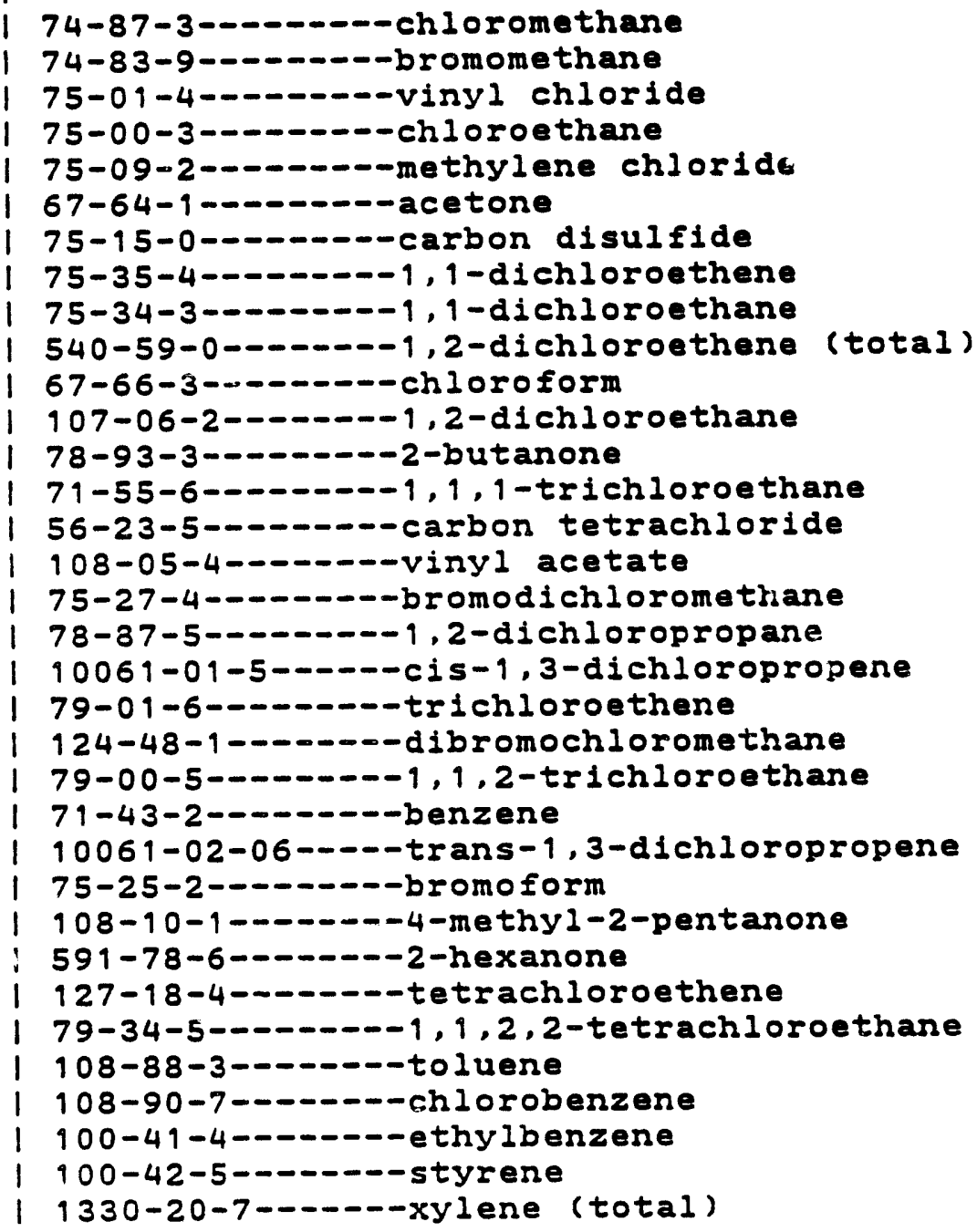

Reviewed by:

\section{0.}

10.

10.

10.

5.00

10 .

5.00

5.00

5.00

5.00

11.

5.00

10.

5.00

5.00

10.

5.00

5.00

5.00

5.00

5.00

5.00

5.00

5.00

5.00

10.

10.

5.00

5.00

5.00

5.00

5.00

5.00

5.00 


\section{VOLATILE ORGANICS ANALYSIS DATA SHEET}

Request Number: OAL94146

Procedure Number: 8240 Matrix: SOIL \& WATER

Series :

Frequency: ON REQUEST

Customer Name:

SIEGRIST

Sample wt/vol:

5 ML

Date Sampled: 19-Feb-1991 14:45

\% Moisture: not dec.

dec:

Material Description WA=ER

Number IICs found: 0
EPA SAMPLE NO.

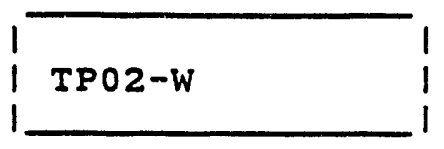

Charge Number: $\quad 33357130$

Lab Sample ID: 910228-056

Lab File ID: >G2110

Date Received 27-Feb-9991 14:30

Date Analyzed: 28-Feb-1991

Date of Report: 2-MAY-91

CONCENTRATION UNITS: (JG/L or UG/KG) UG/L

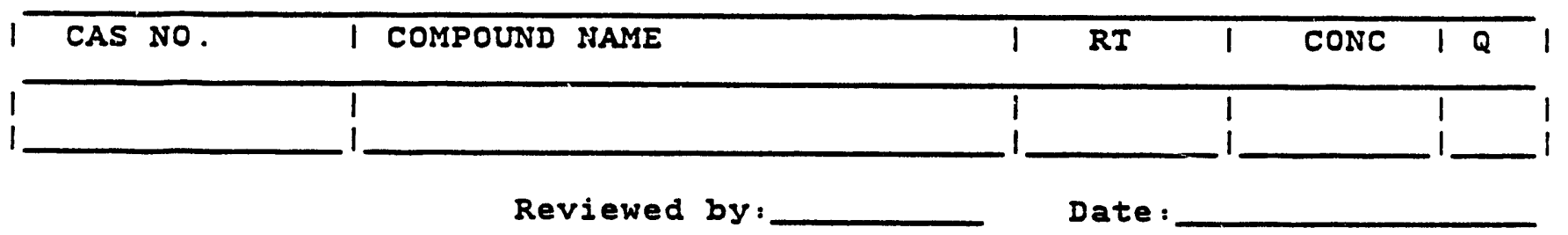


Lab Name: Oak Ridge National Lab

Lab code:

Case no: CLP

Matrix: (soil/water) WATER

Sample wt/vol: $115 \mathrm{ML}$

Level: (low/med) LOW

\% Moisture: not dec. dec.

Extraction: (Sepf/Cont/Sonc) SEPF

GPC Cleanup: $(Y / N) N \quad$ pH: 8.95
Contract: NR

SAS NO: NR

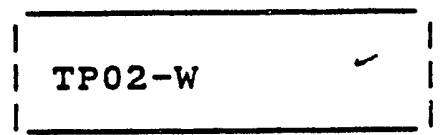

SDG NO: C425

Lab Sample ID: 910228-056

Lab File ID: >C3765

Date Received 28-Feb-1991

Date Aralyzed: 25-Apr-1991

Date Extracted: 18-Mar-1991

Dilution Factor: $\quad 8.7$

CONCENTRATION UNITS:

CAS NO.

COMPOUND (UG/L or UG/KG) UG/L

1 108-95-2----.---phenol

$1911-44-4-\cdots---b$ is (2-chloroethyl)ether

1 95-57-8---..---2-chlorophenol

I 541-73-1--.-.---1,3-dichlorobenzene

1 106-46-7---..---1,4-dichlorobenzene

| 100-51-6---..--benzyl alcohol

1 95-50-1--.-.--1,2-dichlorobenzene

1 95-48-7--.----2-methylphenol

1 108-60-1-.----bis(2-chloroisopropyl)ether

I 106-44-5--.----4-methylphenol

I 621-64-7------n-nitroso-di-n-propylamine

| 67-72-1-...-.-hexachloroethane

| 98-95-3--.-----nitrobenzene

1 78-59-1-..--.--isophorone

I 88-75-5---n----2-nitrophenol

1 105-67-9-------2,4-dimethylphenol

1 65-85-0--------benzoic acid

| $111-91-1------b$ is (2-chloroethoxy)methane

1 120-83-2----n--2, 4-dichlorophenol

1 120-82-1-------1,2,4-trichlorobenzene

I 91-20-3-------naphthalere

I 106-47-8--.---4-chloroaniline

| 87-68-3--.----hexachlorobutadiene

1 59-50-7-.-.---4-chloro-3-methylphenol

1 91-57-6--------2-methylnaphthalene

1 77-47-4-------hexachlorocyclopentadiene

| 88-06-2--.-----2,4,6-trichlorophenol

I 95-95-4-.-----2, 4,5-trichlorophenol

| 91-58-7--n----2-chloronaphthalene

1 88-74-4---.---2-nitroaniline

1 131-19-3------dimethylphthalate

| 208-96-8-------acenaphthylene

| 606-20-2--------2,6-dinitrotoluene

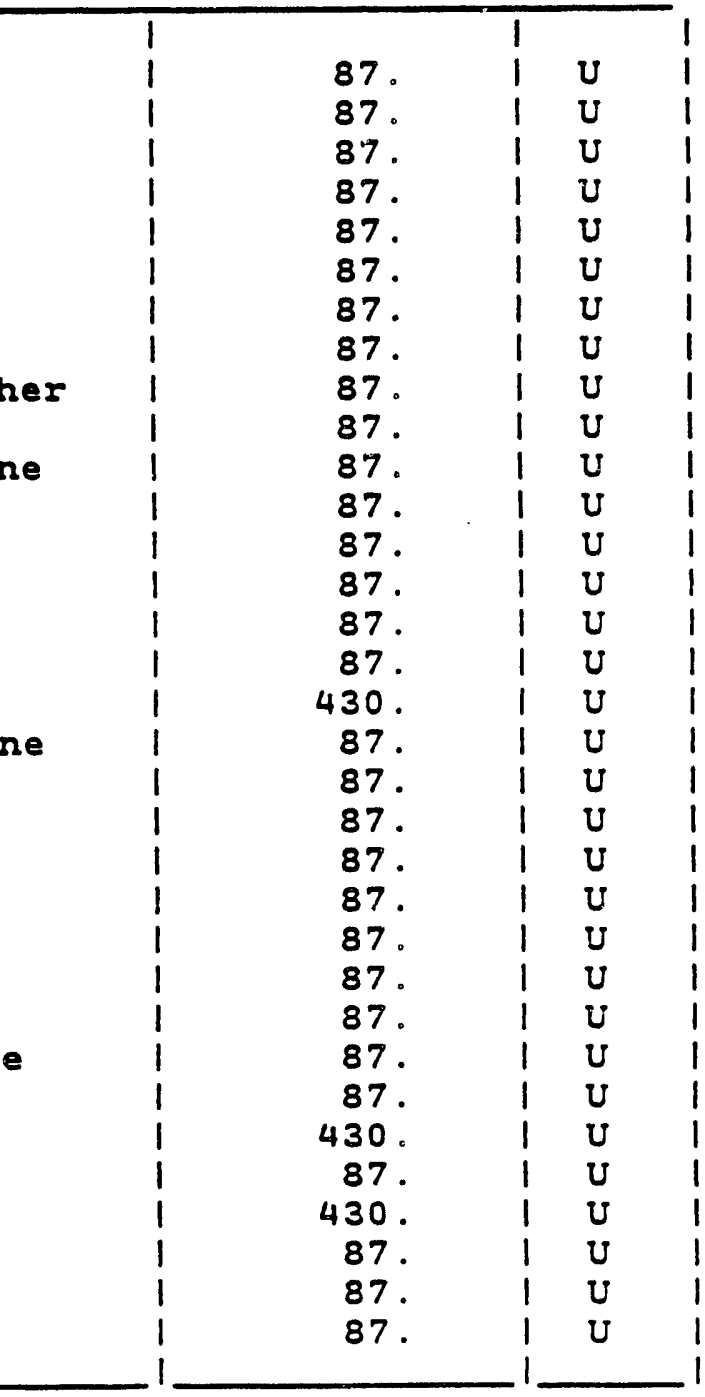


Semivolatile Organic Analysis Data

EPA SAMPLE NO.

Lab Name: Oak Ridge National Lab Contract: NR

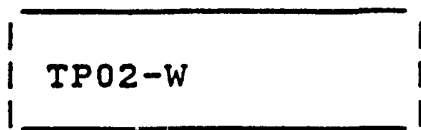

Lab Code: Case no: CLP SAS No: NR SDG No: C425

Matrix: (soil/water) WATER

Lab Sample ID: 910228-056

Sample wt/vol: $\quad 195 \mathrm{ML}$

Lab File ID: $\quad>C 3765$

Level: (low/med) Low

Date Received 28-Feb-1991

\% Moisture: not dec. dec.

Date Analyzed: 25-Apr-1991

Extraction: (Sepf/Cont/Sonc) SEPF

Date Extracted: 18-Mar-1991

GPC Cleanup: $(Y / N) N$

$\mathrm{pH}: \mathbf{8 . 9 5}$

Dilution Factor:

8.7

CAS NO.

COMPOUND

CONCENTRATION UNITS : (UG/L OF UG/KG) UG/L

99-09-2--------3-nitroaniline

83-32-9-------acenaphthene

I 51-28-5--------2,4-dinitrophenol

I 100-02-7------4-nitrophenol

1 132-64-9-------dibenzo furan

1 121-14-2------2,4-dinitrotoluene

1 84-66-2-- - - - diethylphthalate

1 7005-72-3-.----4-chlorophenyl-phenylether

1 86-73-7--n-----fluorene

1 100-01-6--.---4-nitroaniline

1 534-52-1------4,6-dinitro-2-methylphenol

I 86-30-6-n-n-n-nitrosodiphenylamine (1)

1 101-55-3---.----4-bromophenyl-phenylether

I 118-74-1-------hexachlorobenzene

I 87-86-5--.----pentachlorophenol

1 85-01-8-------phenanthrene

1 120-12-7-------anthracene

1 84-74-2--n----di-n-butylphthalate

1 206-44-0------fluoranthene

1 129-00-0-------pyrene

I 85-68-7-------butylbenzylphthalate

I 91-94-1--------3,3'-dichlorobenzidine

| 56-55-3--------benzo(a) anthracene

| 218-01-9-------chrysene

1 117-81-7-----bis (2-ethylhexyl)phthalate

1 117-84-0-------di-n-octylphthalate

1 205-99-2------benzo(b) fluoranthene

I 207-08-9-------benzo(k) fluoranthene

1 50-32-8--.----benzo (a) pyrene

1 193-39-5-------indeno $(1,2,3-c d)$ pyrene

1 53-70-3--.---..dibenz $(a, h)$ anthracene

I 191-24-2-------benzo(g,h, i ) perylene

(1) - Cannot be separated from Diphenylamine
430.

87.

430 .

430 .

87.

87.

87.

87.

87.

430 .

430 .

87.

87.

87.

430 .

87.

87.

87.

87.

87.

160 .

170.

87.

87.

87.

87.

87.

87.

87.

87.

87.

87. 


\section{Semivolatile Organic Analysis Data}

Request Number: OAL94146

Procedure Number: 8240

Matrix: SOIL \& WATER

Series :

Frequency: ON REQUEST

Customer Name: SIEGRIST

$115 \mathrm{ML}$

sample wt/vol:

Date Sampled: 19-Feb-1999 14:45

\% Moisture: not dec.

dec:

Material Description WATER

Number TICS found: 0
EPA SAMPLE NO.

$$
\text { TP02-W }
$$

Lab Sample ID: 910228-056

Lab File ID: $>C 3765$

Date Received 27-Feb-1991 14:30

Date Analyzed: 25-Apr-1991

Date of Report: 2-MAY-91

CONCENTRATION UNITS:

(UG/L OT UG/KG) UG/L

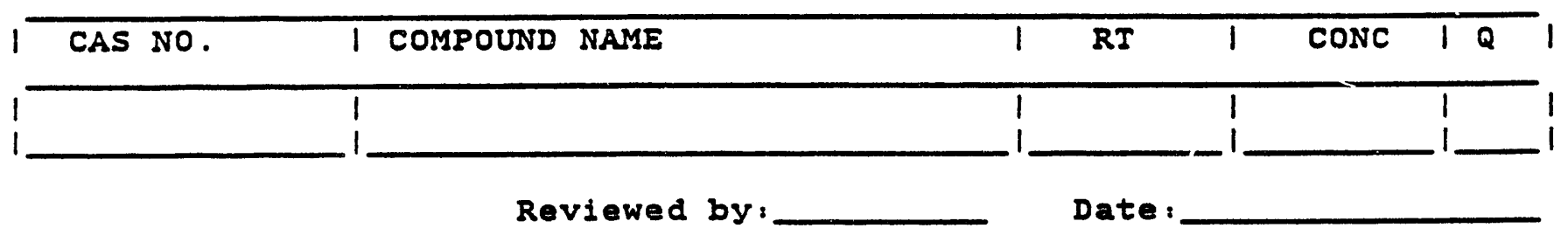


Lab Name: Oak Ridge National Lab

Lab Code:

Case no: ORNL
Matrix: (soil/water) soIL

Sample wt/vol:

5 G

Level: (low/med) LOW

\% Moisture: not dec.

Column: (pack/cap) CAP
Contract: NR

SAS NO: NR

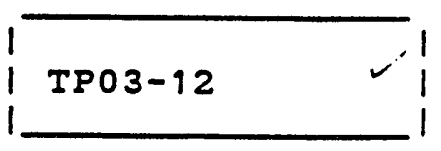

SDG NO: 0308
Lab Sample ID: 910228-057

Lab File ID: $\quad>01196$

Date Received 28-Feb-1991

Date Analyzed: 8-Mar-1991

Dilution Factor: $\quad 1.0$

CAS NO.

COMPOUND

CONCENTRATION UNITS:

(UG/L Or UG/KG) UG/KG

Q

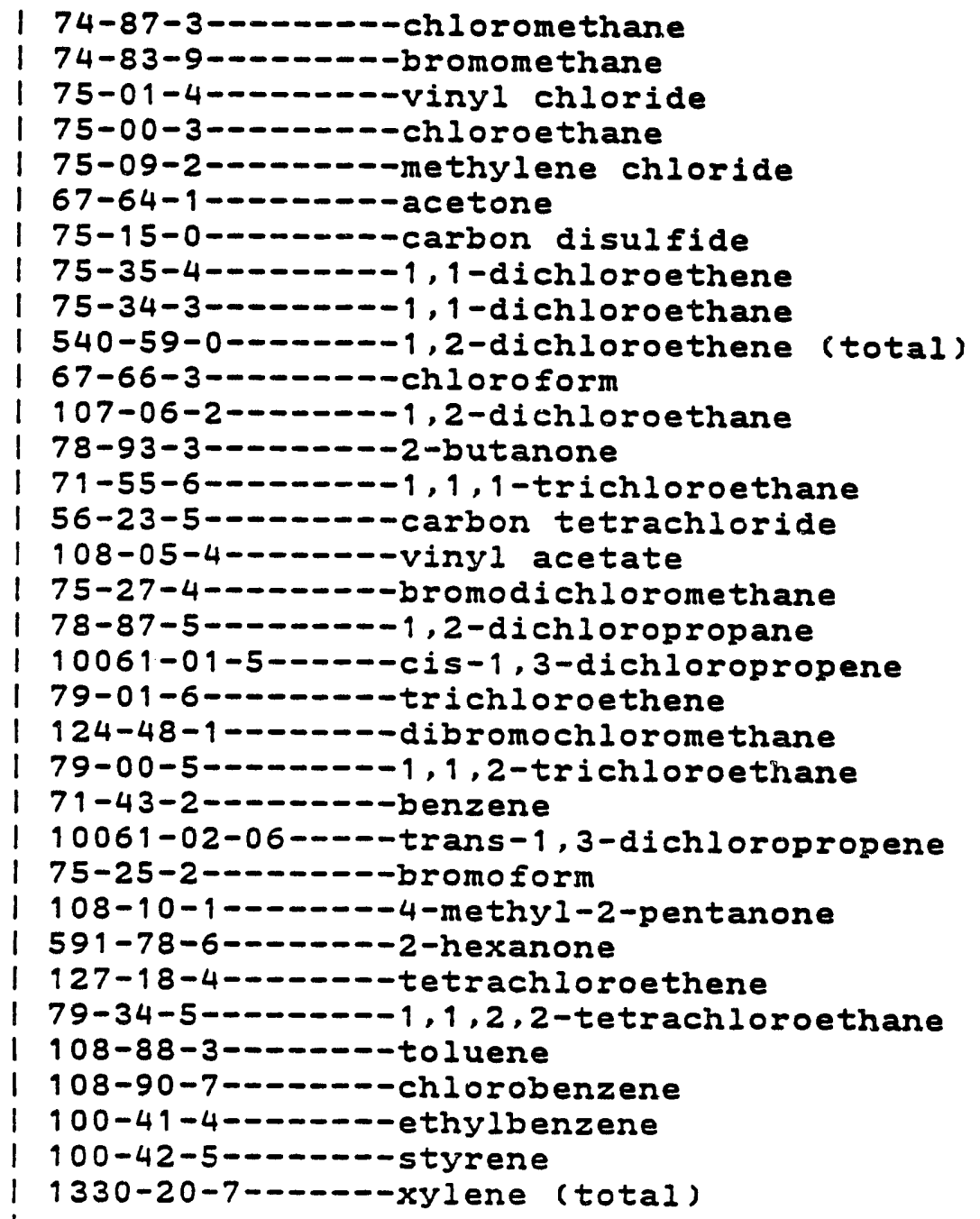


Semivolatile organic Analysis Data

EPA SAMPLE NO.

$\begin{array}{lccc}\text { Lab Name: Oak Ridge National Lab } & \text { Contract: NR } & \text { l- } \\ \text { Lab Code: } & \text { Case no: NR } & \text { SAS No: NR } & \text { SDG No: C319 }\end{array}$

Matrix: (soil/water) soIL

Lab Sample ID: 910228-057

Sample wt/vol: $\quad 30.4 \mathrm{G}$

Lab File ID: $\quad>C 3563$

Level: (low/med) Low

Date Received 28-Feb-1991

r. Moisture: not dec. dec.

Date Analyzed: 19-Mar-1991

Extraction: (Sepf/Cont/Sonc) SONC

Date Extracted: 8-Mar-1991

GPC Cleanup: $(Y / N) \mathrm{N} \quad \mathrm{PH}: \quad \mathrm{NR}$

Dilution Factor: $\quad 1.0$

CAS NO. COMPOUND (UG/L OY UG/KG) UG/KG

Q

\begin{tabular}{|c|c|c|c|c|}
\hline & 1 & & 1 & \\
\hline $\begin{array}{l}108-95-2-\cdots----p h e n o 1 \\
111-44-4-\cdots-n-0 \text { is }(2-c h 10 \text { roethyl }) \text { ether }\end{array}$ & 1 & 330 & 1 & U \\
\hline & 1 & 330. & 1 & $U$ \\
\hline & 1 & $\begin{array}{l}330 \\
330\end{array}$ & 1 & $\begin{array}{l}U \\
U\end{array}$ \\
\hline $\begin{array}{l}541-73-1----1,3-\text { dichlorobenzene } \\
106-46-7-----1,4-\text { dichlorobenzene }\end{array}$ & 1 & $\begin{array}{l}330 . \\
330 .\end{array}$ & 1 & U \\
\hline & 1 & 330. & $i$ & U \\
\hline $\begin{array}{l}100-51-6------ \text { benzyl alcohol } \\
95-50-1-------1,2-\text { dichlorobenzene }\end{array}$ & 1 & 330 & $i$ & U \\
\hline $\begin{array}{l}95-50-1-------1,2-\text { alcndorodenzene } \\
95-48-7--------2-\text { methylphenol }\end{array}$ & $i$ & 330. & 1 & U \\
\hline $108-60-1-\cdots--b i s(2-c h l o r o$ isopropyl $)$ ether & 1 & 330. & 1 & $U$ \\
\hline $106-44-5-\cdots---4-m e t h y l$ phenol & 1 & 330. & 1 & $U$ \\
\hline $621-64-7----n-n-n i t r o s 0-d i-n-p r o p y l a m i n e$ & 1 & 330. & 1 & U \\
\hline 67-72-1----- hexachloroethane & 1 & 330. & 1 & U \\
\hline $98-95-3-------n i t r o b e n z e n e$ & 1 & 330. & 1 & $U$ \\
\hline 78-59-1-------isophorone & 1 & 330. & 1 & $U$ \\
\hline 88-75-5---------2-nitrophenol & 1 & 330. & 1 & $U$ \\
\hline $105-67-9-------2,4-d i m e t h y l$ phenol & 1 & 330. & 1 & $U$ \\
\hline $65-85-0--------$ benzoic acid & 1 & 1600. & 1 & $U$ \\
\hline $111-91-1------b$ is (2-chloroethoxy ) methane & 1 & 330 & 1 & $U$ \\
\hline $120-83-2------2,4-d i c h l o r o p h e n o l$ & 1 & 330. & 1 & U \\
\hline $120-82-1-----1,2,4-t r i c h l o r o b e n z e n e$ & 1 & 330. & 1 & U \\
\hline $91-20-3---\cdots--n a p h t h a l e n e$ & 1 & 330. & 1 & U \\
\hline $106-47-8-----4-\operatorname{chl}$ oroaniline & 1 & 330. & 1 & $U$ \\
\hline 87-68-3--------hexachlorobutadiene & 1 & 330. & 1 & $U$ \\
\hline 59-50-7--------4-chloro-3-methylphenol & 1 & 330. & 1 & $U$ \\
\hline $91-57-6--------2-$ methylnaphthalene & 1 & 330. & 1 & $U$ \\
\hline 77-47-4------hexachlorocyclopentadiene & 1 & 330. & 1 & $\mathrm{U}$ \\
\hline 88-06-2-------2, 4,6-trichlorophenol & 1 & 330 & 1 & $U$ \\
\hline $95-95-4-------2,4,5-t r i c h l o r o p h e n o l$ & 1 & 9600 . & 1 & $U$ \\
\hline $91-58-7-------2-c h l o r o n a p h t h a l e n e$ & 1 & 330 . & 1 & $U$ \\
\hline 88-74-4--------2-nitroaniline & 1 & 1600. & 1 & $U$ \\
\hline 131-11-3------dimethylphthalate & 1 & 330 & 1 & $U$ \\
\hline 208-96-8--------acenaphthylene & 1 & 330. & 1 & $U$ \\
\hline $60 t-20-2------2,6-$ dinitrotoluene & 1 & 330. & 1 & $U$ \\
\hline
\end{tabular}


Semivolatile Organic Analysis Data

EPA SAMPLE NO.

Lab Name: Oak Ridge National Lab

Lab Code: Case no: NR
Contract: NR

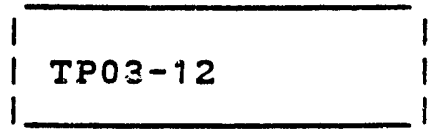

Matrix: (soil/water) soIL

Sample wt/vol: $\quad 30.4 \mathrm{G}$

Level: (low/med) Low

\% Moisture: not dec. dec.

Extraction: (Sepf/Cont/Sorc) SONC

GPC Cleanup: $(Y / N) N \quad$ pH: NR

GPC Cleanup: $(Y / N) N \quad$ PH: NR
SAS NO: NR
SDG NO: C319
Lab Sample ID: 910228-057

Lab File ID: >C3563

Date Received 28-Feb-1991

Date Aralyzed: 19-Mar-1991

Date Extracted: 8-Mar-1991

CAS NO.

COMPOUND

CONCENTRATION UNTTS: (UG/L OI UG/KG) UG/KG

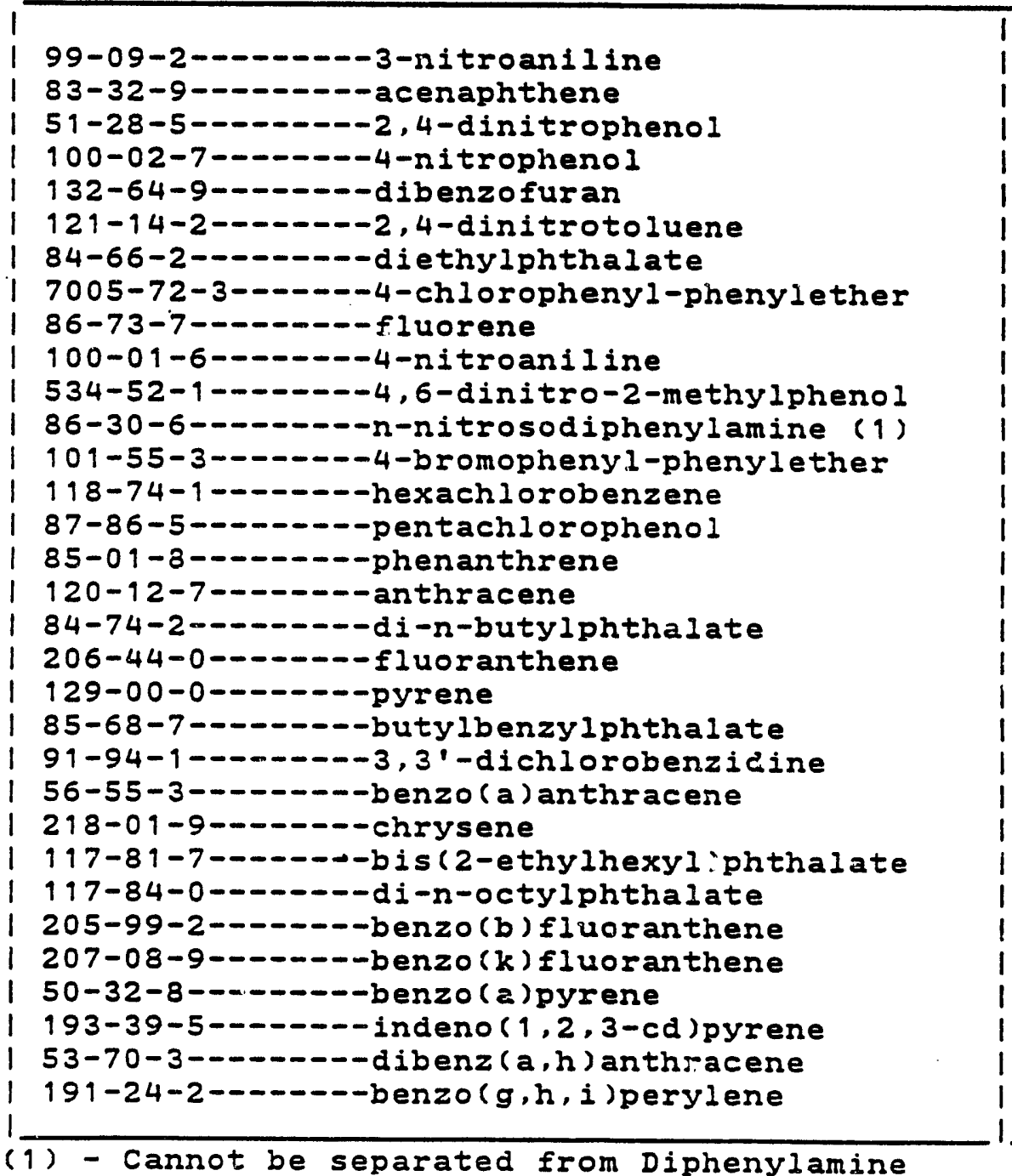

Reviewed by:

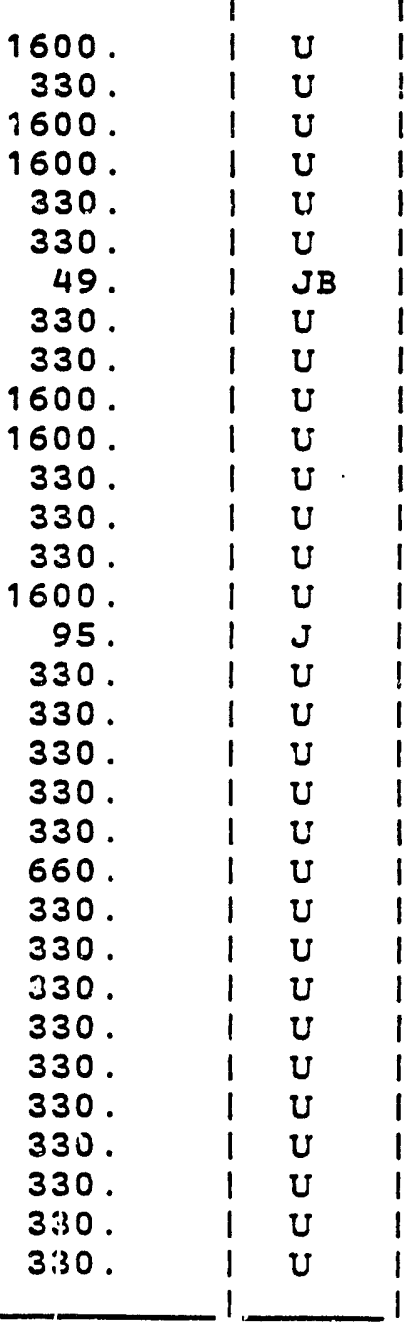

Date : 
Semivolatile Organic Analysis Data

Request Number: OAL 94146

Procedure Number: 8240

Matrix: SOIL \& WATER

Frequency: ON REQUEST Charge Number:

33357130

Series:

Vustomer Name: SIEGRIST

Lab Sample ID: 910228-057

Sample wt/vol: $\quad 30.4 \mathrm{G}$

Date Sampled: 19-Feb-1991 16:30

\% Moisture: not dec.

dec:

Material Description SOIL

Number IICs found: 8

Lab File ID: >C3563

Date Received 27-Feb-1991 14:30

Date Analyzed: 19-Mar-1991

Date of Report: 2-MAY-91

CONCENTRATION UNITS:
EPA SAMPLE NO.

TP03-12

(UG/L Or UG/KG) UG/KG

\begin{tabular}{|c|c|c|c|c|c|c|c|}
\hline CAS NO. & I COMPOUND NAME & 1 & $\mathbf{R T}$ & 1 & CONC & 1 & $Q$ \\
\hline $\begin{array}{l}1 . \\
2 . \\
3 . \\
4 . \\
5 . \\
6 . \\
7: \\
8 .\end{array}$ & $\begin{array}{l}\text { I IOLUENE-SOLVENT IN STD SOLNS } \\
\text { I UNKNOWN } \\
\text { I UNKNOWN } \\
\text { I UNKNOWN } \\
\text { I UNKNOWN } \\
\text { I UNKNOWN } \\
\text { I ETHANE, } 1,1,2,2 \text {-TEIRACHLORO- } \\
\text { I UNKNOWN }\end{array}$ & $\begin{array}{l}1 \\
1 \\
1 \\
1 \\
1 \\
1 \\
1 \\
1 \\
1\end{array}$ & $\begin{array}{r}7.23 \\
8.33 \\
8.60 \\
8.86 \\
10.26 \\
11.32 \\
11.40 \\
15.14\end{array}$ & $\begin{array}{l}1 \\
1 \\
1 \\
1 \\
1 \\
1 \\
1 \\
1\end{array}$ & $\begin{array}{l}420 . \\
180 . \\
230 . \\
170 . \\
130 . \\
130 . \\
230 . \\
160 .\end{array}$ & $\begin{array}{l}1 \\
1 \\
1 \\
1 \\
1 \\
1 \\
1 \\
1 \\
1\end{array}$ & $\begin{array}{l}J B \\
J \\
J \\
J \\
J B \\
J \\
J B \\
J\end{array}$ \\
\hline
\end{tabular}


Lab Name: Oak Ridge National Lab Lab Code: Case nO: ORNL

Matrix: (soil/water) soIL sample wt/vol:

5 G

Level: (low/med) Low

\% Moisture: not dec.

Column: (pac':/cap) CAP
Contract: NR

SA.S NO: NR

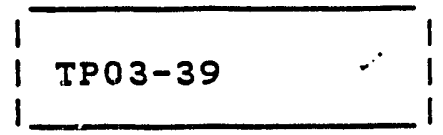

SDG NO: 0308
Lab Sample ID: 910228-058

Lab File ID: $\quad>01197$

Date Received 28-Feb-1991

Date Analyzed: 8-Mar-1991

Dilution Factor: $\quad 1.0$

CAS No.

COMPOUND

CONCENTRATION UNITS:

(UG/L Or UG/KG) UG/KG

Q

\begin{tabular}{|c|}
\hline 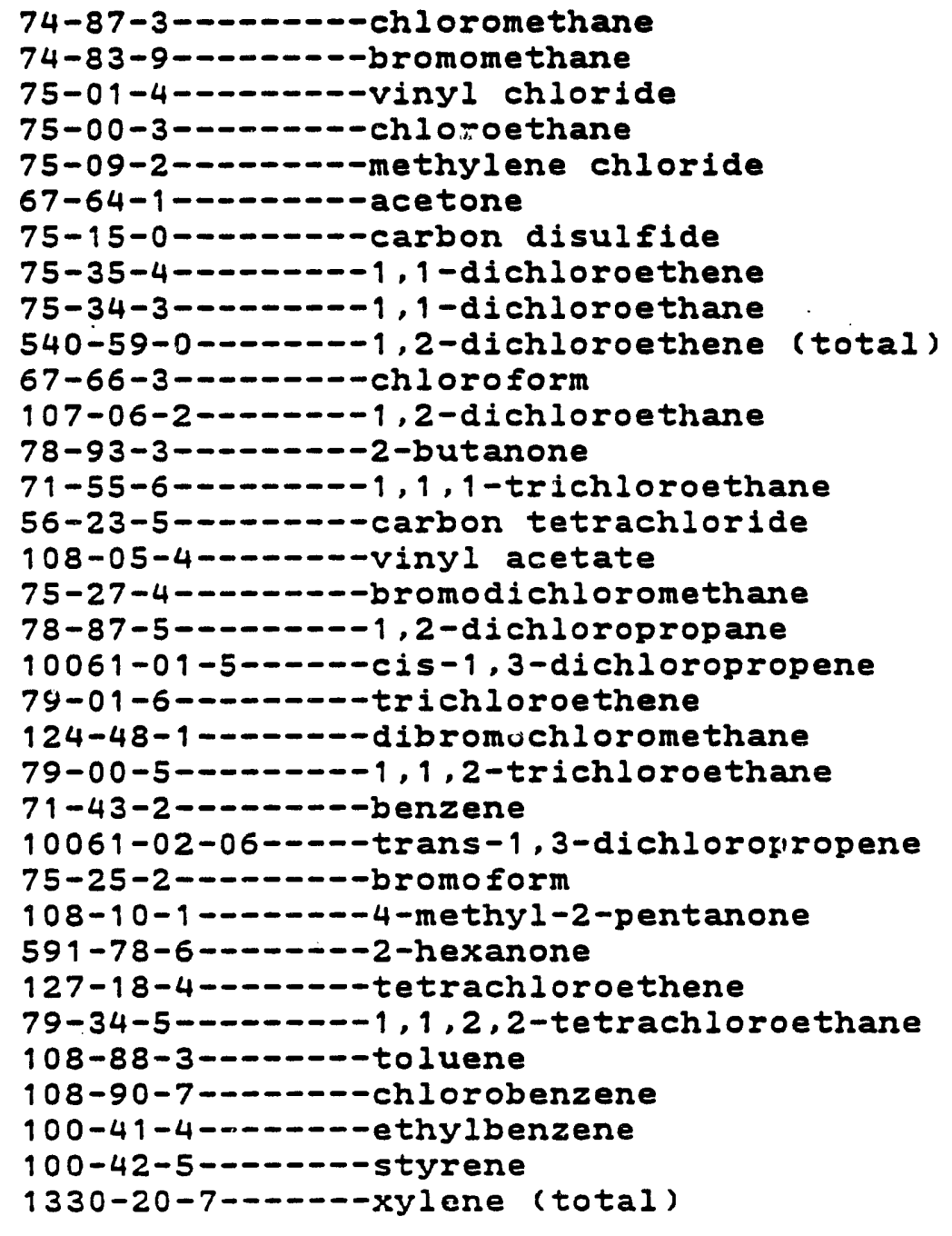 \\
\hline
\end{tabular}

Reviewed by:

Dare: 
Semivolatile organic Analysis Data

Lab Name: Oak Ridge National Lab Contract: NR
Case no: NR

Matrix: (soil/water) SOIL

Sample wt/vol: $32.7 \mathrm{G}$

Level: (low/med) LOW

\% Moisture: not dec. dec.

Extraction: (Sepf/Cont/Sonc) SoNC

GPC Cleanup: $(Y / N) N$

pH : NR
EPA SAMPLE NO.

SAS NO: NR

SDG NO: 6319

\section{TPO3-39}

Lab Sample ID: 910228-058

Lab File ID: $\quad>C 3564$

Date Received 28-Feb-1991

Date Analyzed: 20-Mar-1991

Date Extracted: 8-Mar-1991

Dilution Factor: $\quad 1.0$

CONCENTRATION UNITS:

CAS NO. COMPOUND (UG/L OI UG/KG) UG/KG

Q

\begin{tabular}{|c|c|c|c|c|}
\hline 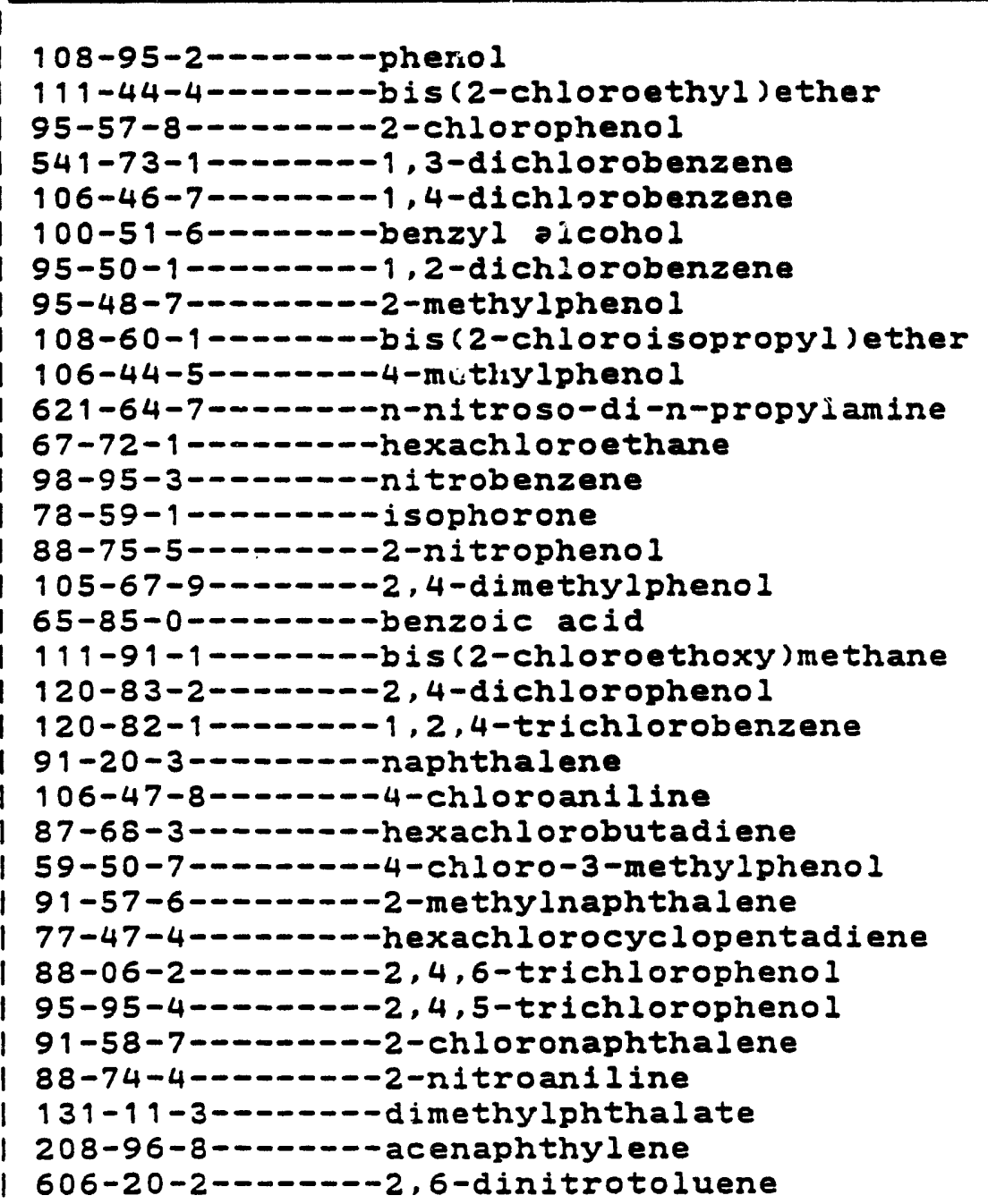 & $\begin{array}{l}1 \\
1 \\
1 \\
1 \\
1 \\
1 \\
1 \\
1 \\
1 \\
1 \\
1 \\
1 \\
1 \\
1 \\
1 \\
1 \\
1 \\
1 \\
1 \\
1 \\
1 \\
1 \\
1 \\
1 \\
1 \\
1 \\
1 \\
1 \\
1 \\
1 \\
1\end{array}$ & $\begin{array}{r}310 . \\
310 . \\
310 . \\
310 . \\
310 . \\
310 . \\
310 . \\
310 . \\
310 . \\
310 . \\
310 . \\
310 . \\
310 . \\
310 . \\
310 . \\
310 . \\
1500 . \\
310 . \\
310 . \\
310 . \\
310 . \\
310 . \\
310 . \\
310 . \\
310 . \\
310 . \\
310 . \\
1500 . \\
310 . \\
1500 . \\
310 . \\
310 . \\
310 .\end{array}$ & $\begin{array}{l}1 \\
1 \\
1 \\
1 \\
1 \\
1 \\
1 \\
1 \\
1 \\
1 \\
1 \\
1 \\
1 \\
1 \\
1 \\
1 \\
1 \\
1 \\
1 \\
1 \\
1 \\
1 \\
1 \\
1 \\
1 \\
1 \\
1 \\
1 \\
1 \\
1 \\
1 \\
1\end{array}$ & $\begin{array}{l}U \\
U \\
U \\
U \\
U \\
U \\
U \\
U \\
U \\
U \\
U \\
U \\
U \\
U \\
U \\
U \\
U \\
U \\
U \\
U \\
U \\
U \\
U \\
U \\
U \\
U \\
U \\
U \\
U \\
U \\
U \\
U \\
U\end{array}$ \\
\hline
\end{tabular}


Semivolatile Organic Analysis Data

Lab Name: Osk Ridge National Lab Contract, NR

Lab Code:

Case no: NR

SAS NO: NR

SDG NO: C319

Matrix: (soil/water) soIL

Lab Sample ID: 910228-058

Sample wt/vol: $\quad 32.7 \mathrm{G}$

Lab File ID: $\quad>C 3564$

Level: (low/med) Low

Date Received 28-Feb-1991

\% Moisture: not dec.

dec.

Date Analyzed: 20-Mar-1991

Extraction: (Sepf/Cont/Sone) sonc

Date Extracted: 8-Mar-1991

GPC Cleanup: $(Y / N) N$

PH: NR

Dilution Factor:

1.0

CAS No.

COMPOUND

CONCENTRATION UNITS:

(UG/L Or UG/KG) UG/KG

Q

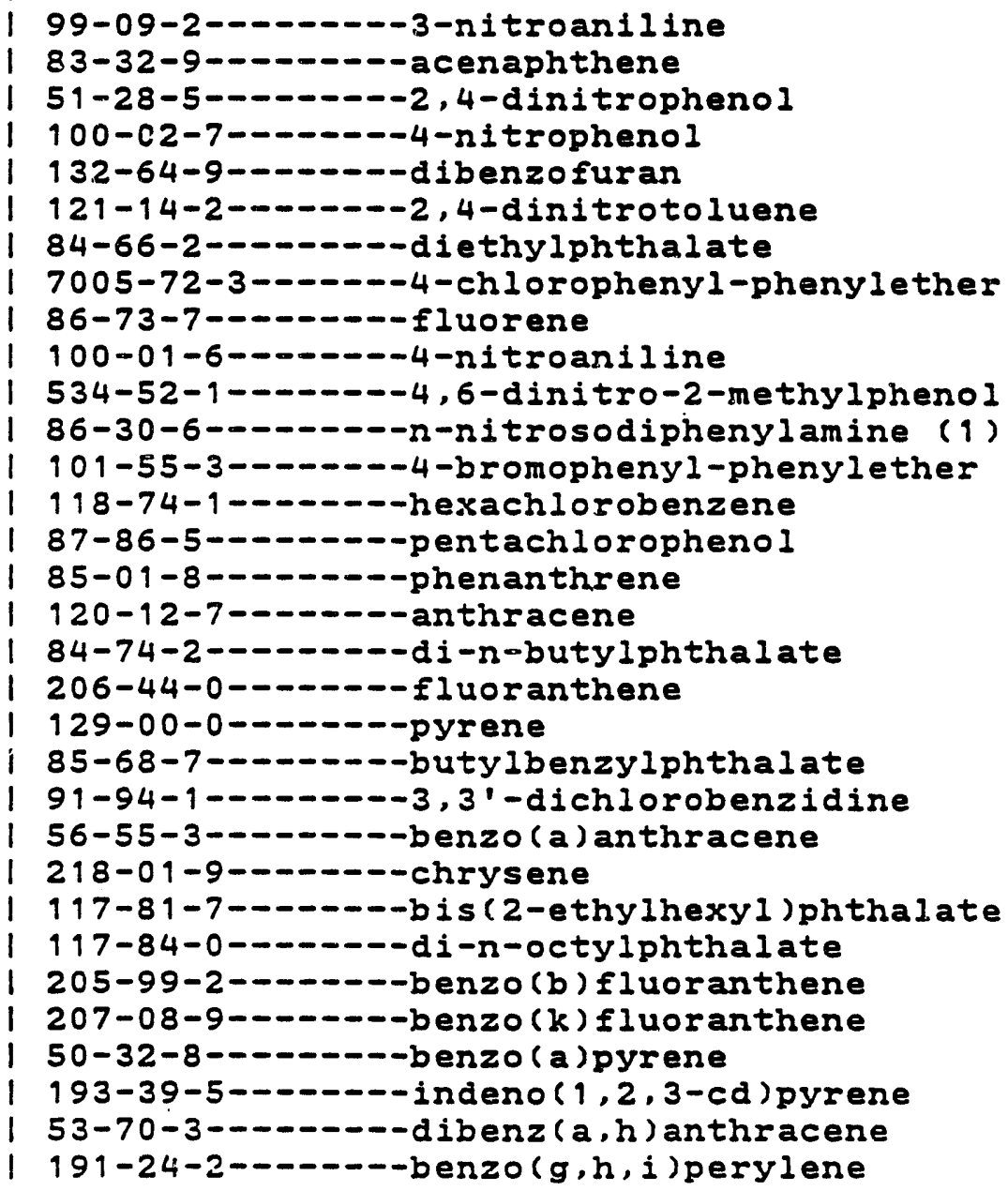

(1) - Cannot be separated from Diphenylamine

Reviewed by : 
Semivolatile organic Analysis Data

Request Number: OAL94146

EPA SAMPLE NO.
Procedure Number: 8240
Matrix: SOIL \& WATER

TPO3-39

Series:

Frequency: ON REQUEST

Charge Number: $\quad 33357130$

IUstomer Name: SIEGRIST

Lab Sample ID: 910228-058

Sample wt/vol:

$32.7 \mathrm{G}$

Lab File ID: $\quad>C 3564$

Jate Sampled: 19-Feb-1991 16:50

Date Received 27-Feb-1991 14:30

: Moisture: not dec.

dec:

Date Analyzed: 20-Mar-1991

Material Description soll

Date of Report: 2-MAY-91

Number TICs found: 9

CONCENTSATION UNITS:

(UG/L or UG/KG) UG/KG

\begin{tabular}{|c|c|c|c|c|c|c|c|}
\hline CAS NO. & I COMPOUND NAME & 1 & $\mathbf{R T}$ & 1 & CONC & 1 & Q \\
\hline $\begin{array}{l}1 . \\
2 . \\
3 . \\
4 . \\
5 \\
6 . \\
7 . \\
7 . \\
8 \\
9\end{array}$ & $\begin{array}{l}\text { I TOLUENE-SOLVENT IN STD SOLNS } \\
\text { I UNKNOWN } \\
\text { IUNKNOWN } \\
\text { I ETHANE, } 1,1,2,2 \text {-TETRACHLORO- } \\
\text { I UNKNOWN } \\
\text { IUNKNOWN } \\
\text { IUNKNOWN } \\
\text { I UNKNOWN } \\
\text { IUNKNOWN }\end{array}$ & $\begin{array}{l}1 \\
1 \\
1 \\
1 \\
1 \\
1 \\
1 \\
1 \\
1 \\
1\end{array}$ & $\begin{array}{r}7.19 \\
8.31 \\
8.57 \\
11.39 \\
32.78 \\
33.93 \\
35.03 \\
36.08 \\
37.10\end{array}$ & $\begin{array}{l}1 \\
1 \\
1 \\
1 \\
1 \\
1 \\
1 \\
1 \\
1\end{array}$ & $\begin{array}{l}200 . \\
140 . \\
130 . \\
130 . \\
280 . \\
670 . \\
690 . \\
480 . \\
240 .\end{array}$ & $\begin{array}{l}1 \\
1 \\
1 \\
1 \\
1 \\
1 \\
1 \\
1 \\
1\end{array}$ & $\begin{array}{l}\mathrm{JB} \\
\mathrm{J} \\
\mathrm{J} \\
\mathrm{JB} \\
\mathrm{J} \\
\mathrm{J} \\
\mathrm{J} \\
\mathrm{J} \\
\mathrm{J}\end{array}$ \\
\hline
\end{tabular}


Lab Name: Oak Ridge National Lab

Lab Code :

Case no: ORNL

Matxix: (soil/yater) soIL

Sample wt/vol: $\quad 5$ G

Level: (low/med) Low

\% Moisture: not dec.

Column: (pack/cap) PACK
Contract: $N R$

SAS NO: NR

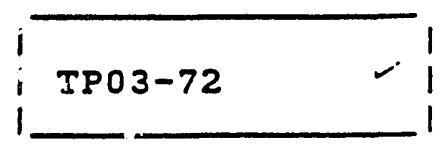

SDG NO: G304
Lab Sample ID: 910228-059

Lab File ID: >G2142

Date Received 28-Feb-1991

Date Analyzed: 4-Mar-1991

Dilution Factor: $\quad 1.0$

CAS NO.

COMPOUND

CONCENTRATION UNITS:

(UG/L Or UG/KG) UG/KG

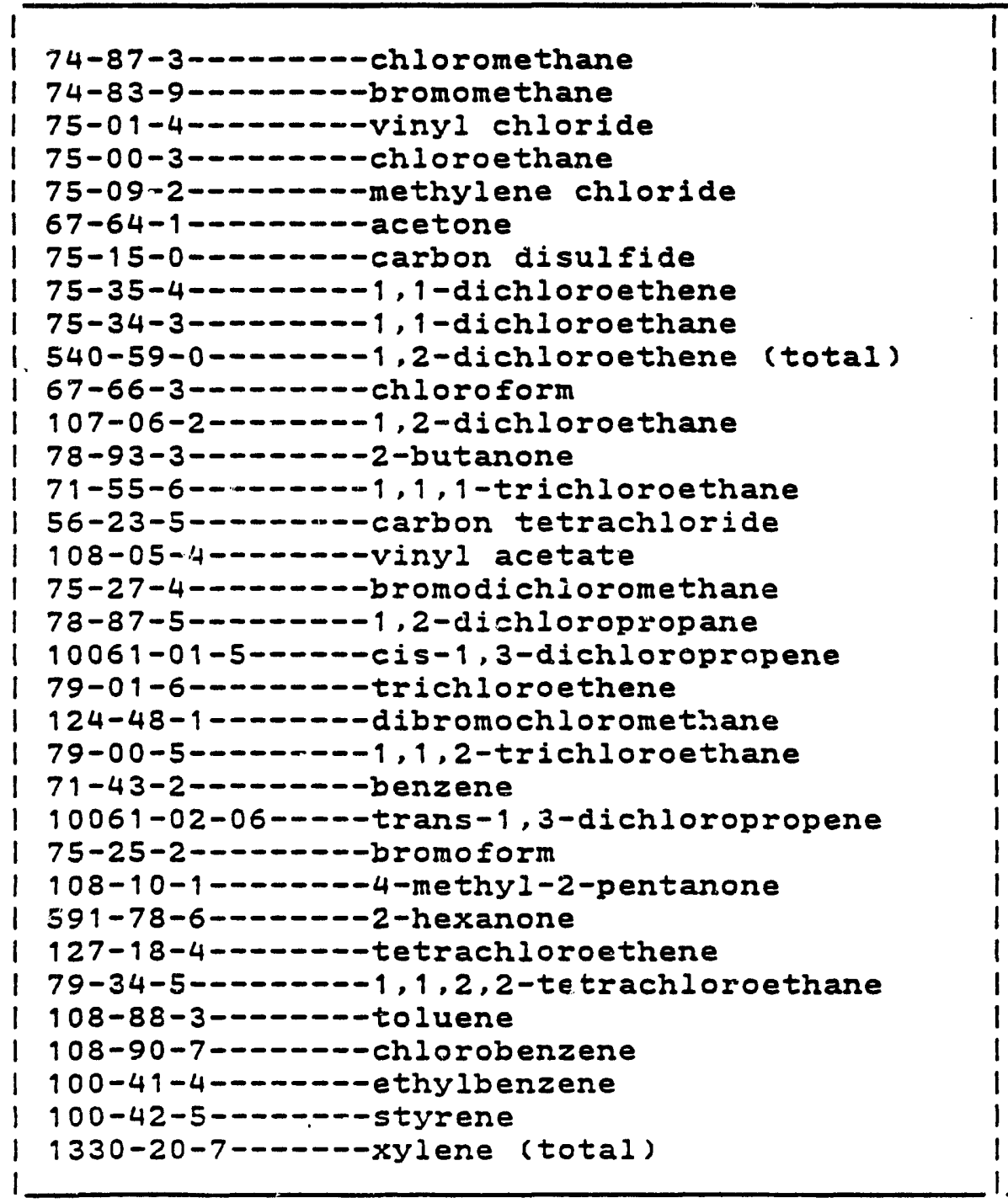

Reviewed by :

Date : 


\section{VOLATILE ORGANICS ANALYSIS DATA SHEET}

Request Number: OAI94146

Procedure Number: 8240 Matrix: SOIL \& WA.TER

EPA SAMPLE NO.

Series :

Frequency: ON REQUEST

Charge Number:

33357130

zustomer Name: SIEGRIST

Lab Sample ID: 910228-059

Sample wt/vol:

5 G

Lab File ID: $\quad>62142$

Jate Sampled: 19-Feb-1991 16:15

Date Received 27-Feb-1991 14:30

* Moisture: not dec.

dec:

Date Aralyzed: 4-Mar-1991

laterial Description SoIL

Date of Report: 2-MAY-91

Number TICs found: 0

CENCENTRATION UNITS:

(UG/L OI UG/KG) UG/KG

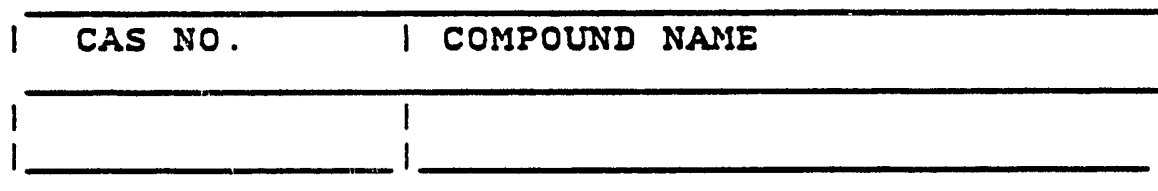

Reviewed by:

I RT

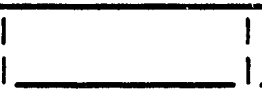

Date 
Semivolatile Organic Analysis Data

Lab Name: Oak Ridge National Lab Contract: NR

EPA SAMPLE NO.

Lab Code: Case no: NR

Matrix: (soil/water) soIL

Sample wt/vol: $\quad 39.2 \mathrm{G}$

Level: (low/med) LOW

\% Moisture: not dec. dec.

Extraction: (Sepf/Cont/Sonc) soNC

GPC Cleanup: $(Y / N) N \quad P H: \quad N R$
SAS NO: NR

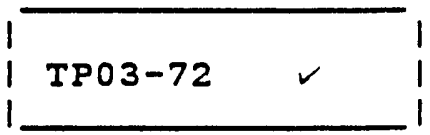

SDG NO: 6319

Lab Sample ID: 910228-059

Lab File ID: $\quad>C 3559$

Date Received 28-Feb-1991

Date Analyzed: 19-Mar-1991

Date Extracted: 8-Mar-1991

Dilution Factor: $\quad 1.0$

CAS No.

COMPOUND

CONCENTRATION UNITS:

(UG/L OY UG/KG) UG/KG

Q

\begin{tabular}{|c|c|c|c|c|}
\hline & 1 & & $!$ & \\
\hline $108-95-2------$ phenol & $i$ & 320 . & $i$ & $U$ \\
\hline $111-44-4------b i s(2-c h l o r o e t h y l)$ ether & $i$ & 320. & $i$ & $U$ \\
\hline $95-57-8-------2-c h l o r o p h e n o l$ & i & 320 . & 1 & $U$ \\
\hline 541-73-1-------1,3-dichlorobenzene & 1 & 320 . & 1 & $u$ \\
\hline $106-46-7------1,4-d i c h l o r o b e n z e n e$ & 1 & 320 . & 1 & $\mathrm{U}$ \\
\hline 100-51-6------benzyl alcohol & 1 & 320. & 1 & $U$ \\
\hline $95-50-1-------1,2-$ dichlorobenzene & 1 & 320 . & 1 & $\mathrm{U}$ \\
\hline $95-48-7---------2-$ methylpheris 1 & 1 & 320. & 1 & U \\
\hline 108-60-1-----bis(2-chloroisopropyl)ether & 1 & 320 . & 1 & U \\
\hline $106-44-5------4-$ methylphenol & 1 & 320 . & 1 & U \\
\hline 621-64-7--n--n-nitroso-di-n-propylamine & 1 & 320 . & 1 & ن \\
\hline $67-72-1--------$ hexachloroethane & 1 & 320. & 1 & $U$ \\
\hline 98-95-3-------nitrobenzene & 1 & 320 . & 1 & $U$ \\
\hline 78-59-1--------isophorone & 1 & 320 . & 1 & $U$ \\
\hline 88-75-5--------2-nitrophenol & 1 & 320 . & 1 & $U$ \\
\hline 105-67-9--------2,4-dimethylphenol & 1 & 320. & 1 & $U$ \\
\hline 65-85-0--------benzoic acid & 1 & 1600. & 1 & $\mathrm{U}$ \\
\hline 111-91-1-----bis(2-chloroethoxy) methane & 1 & 320 . & 1 & $U$ \\
\hline $120-83-2-------2,4-d i c h l o r o p h e n o l$ & 1 & 320 . & 1 & $\mathrm{U}$ \\
\hline 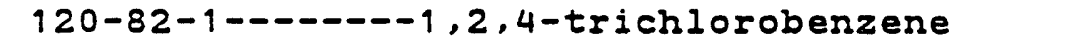 & $\mathbf{i}$ & 320 . & 1 & $\mathrm{U}$ \\
\hline $91-20-3-------$ naphthalene & 1 & 320. & 1 & $\mathbf{U}$ \\
\hline $106-47-8------4-c h l o r o a n i l i n e$ & 1 & 320 . & 1 & $\mathrm{U}$ \\
\hline 87-68-3-------hexachlorobutadiene & $i$ & 320 . & $i$ & U \\
\hline - - -4-chloru-3-methylphenol & 1 & 320. & 1 & $\mathrm{U}$ \\
\hline $91-57-6--------2-$ methylnaphthalene & 1 & 320 . & 1 & $\mathrm{U}$ \\
\hline 77-47-4---n-nexachlorocyclopentadiene & 1 & 320 . & 1 & U \\
\hline 88-06-2--------2,4,6-trichlorophenol & 1 & 320 . & 1 & $\mathrm{U}$ \\
\hline $95-95-4------2,4,5-\operatorname{trichlorophenol}$ & 1 & 1600 & i & $U$ \\
\hline $91-58-7--------2-c h l o r o n a p h t h a l e n e$ & 1 & 320. & 1 & $U$ \\
\hline 88-74-4---------2-nitroaniline & 1 & 1600. & 1 & $\mathbf{U}$ \\
\hline 131-11-3-------dimethylphthalate & 1 & 320. & 1 & $\mathrm{U}$ \\
\hline 208-96-8-------acenaphthylene & 1 & 320 . & 1 & $\mathrm{U}$ \\
\hline $606-20-2-----2,6-$ dinitrotoluene & 1 & 320 . & 1 & $\mathrm{U}$ \\
\hline
\end{tabular}


Lab Name: Oak Ridge National Lab Lab Code : Case no: NR

Matrix: (soil/water) soIL

Sample wt/vol: $\quad 31.2 \mathrm{G}$

Level: (low/med) Low

\% Moisture: not dec. dec.

Extraction: (Sepf/Cont/Sonc) sonc GPC Cleanup: $(Y / N) N$ PH : NR
Contract: NR
1 TPO3-72
SAS NO: NR SDG NO: C319

Lab File ID: >C3559

Date Received 28-Feb-1991

Date Aralyzed: 19-Mar-1991

Daie Extracted: 8-Mar-1991

Dilution Factor: $\quad 1.0$

CAS NO.

COMPOUND

CONCENTRATION UNITS:

(UG/L Or UG/KG) UG/KG

Q

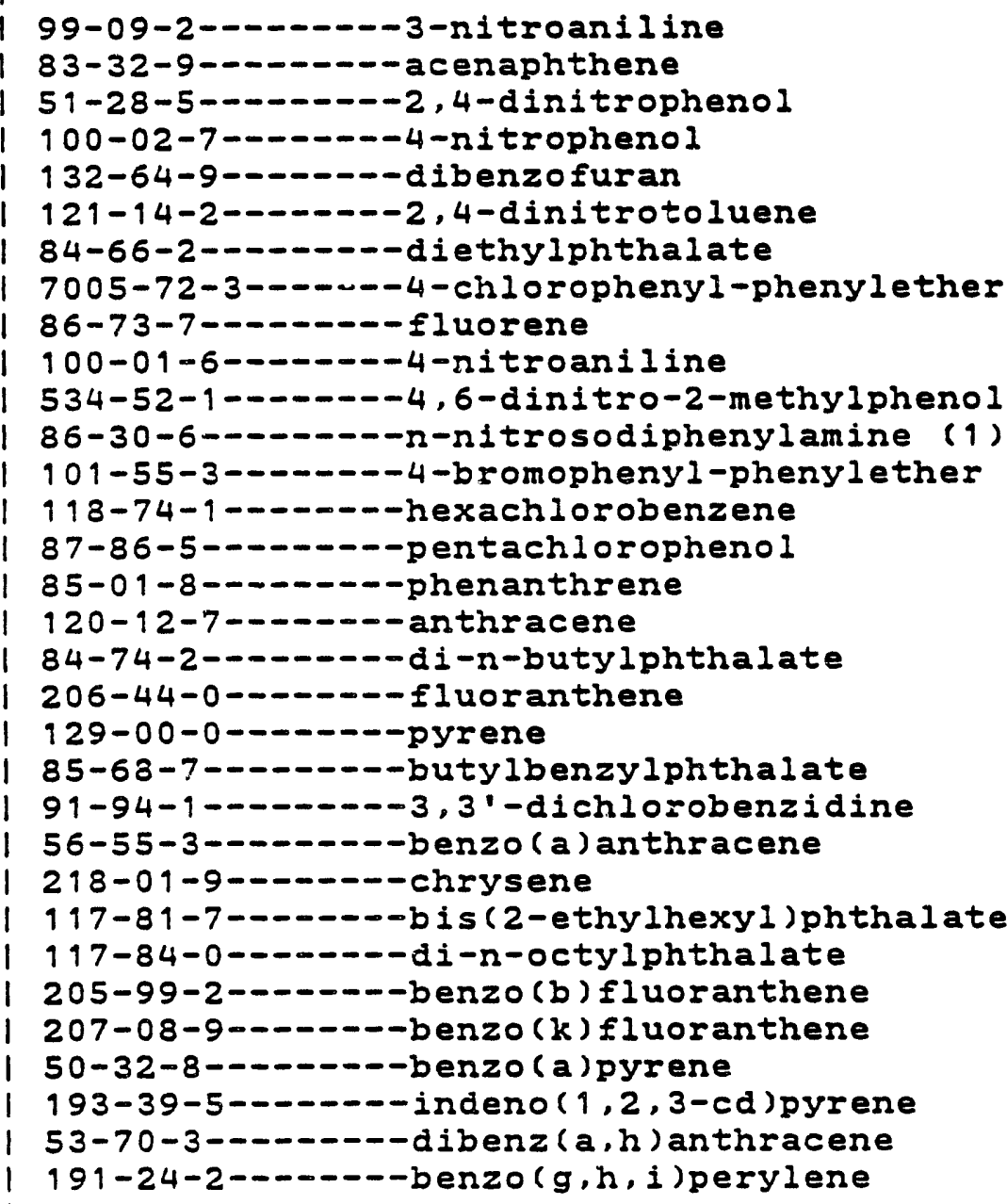

(1) - Cannot be separated from Diphenylamine
1600 .

320 .

1600 .

1600 .

320 .

320 .

48 .

320 .

320 .

1600 .

1600 .

320 .

320 .

320 .

1600 .

320 .

320 .

320 .

320 .

320 .

320 .

640 .

320 .

320 .

320 .

320 .

320 .

320 .

320 .

320 .

320 .

320 . 
Semivolatile Organic Analysis Data

Request Number: OAL94146

Procedure Number: 8240

Matrix: SOIL \& WATER

EPA SAMPLE NO.

Series:

Frequency: ON REQUEST

Charge Number:

33357130

Customer Name: SIEGRIST

Lab Sample ID: 910228-059

Sample wt/vol: $\quad 31.2 \mathrm{G}$

Lab File ID: >C3559

Date Sampled: 19-Feb-1991 16:15

Date Received 27-Feb-1991 14:30

\% Moisture: sot dec.

dec:

Date Analyzed: 19-Mar-1991

Material Description SoIL

Date of Report: 2-MAY-91

Number TICs found: 13

CONCENTRATION UNITS:

(UG/L or UG/KG) UG/KG

\begin{tabular}{|c|c|c|c|c|c|c|c|}
\hline CAS NO. & I COMPOUND NAME & 1 & RT & 1 & CONC & 1 & $\mathbf{Q}$ \\
\hline $\mid$ & 1 & $!$ & & 1 & & 1 & \\
\hline 11. & IACETIC ACID & 1 & 5.29 & 1 & 3900. & 1 & JB \\
\hline 2 & ITOLUENE-SOLVENT IN STD SOLNS & 1 & 7.25 & 1 & 360 & 1 & JB \\
\hline 3 & I UNKNOWN & 1 & 8.62 & 1 & 180. & 1 & $\mathbf{J}$ \\
\hline 4. & IETHANE $, 1,1,2,2$-TETRACHLORO & i & 11.41 & $i$ & 190. & $i$ & JB \\
\hline 5 . & I UNKKNOWN & 1 & 32.79 & 1 & 130. & 1 & $\mathrm{~J}$ \\
\hline 6. & I UNKNOWN & I & 33.93 & 1 & 490. & 1 & J \\
\hline 7. & I UNKNOWN & 1 & 35.03 & 1 & 730. & 1 & $\mathrm{~J}$ \\
\hline 8. & I UNKNNOWN & 1 & 36.05 & 1 & 860. & 1 & $\mathbf{J}$ \\
\hline 9. & I UNKNOWN & I & 37.11 & 1 & 840. & 1 & $J$ \\
\hline 110. & I UNKNOWN & 1 & 38.08 & 1 & 650. & 1 & $J$ \\
\hline 191. & | UNKNOWN & 1 & 39.03 & 1 & 680. & 1 & $J$ \\
\hline 112. & I UNKNOWN & 1 & 40.03 & 1 & 440. & 1 & $J$ \\
\hline 113. & | UNKNOWN & I & 41.15 & 1 & 180. & 1 & $\mathrm{~J}$ \\
\hline
\end{tabular}


Lab Name: Oal: Ridge National Lab Contract: NR

Lab Code:

Case nO: ORNI

Matrix: (soil/water) WATER

Sample wt/vol:

5 ML

Level: (low/med) Low

\# Moisture: not dec.

Column: (pack/cap) PACK
SAS NO: NR
TPO3-W

SDG NO: 6228
Lab Sample ID: $910228-060$

Lab File ID: >G2111

Date Received 28-Feb-1991

Date Analyzed: 28-Feb-1991

Dilution Factor: $\quad 1.0$

CAS NO. COMPOUND (UG/L OY UG/KG) UG/L

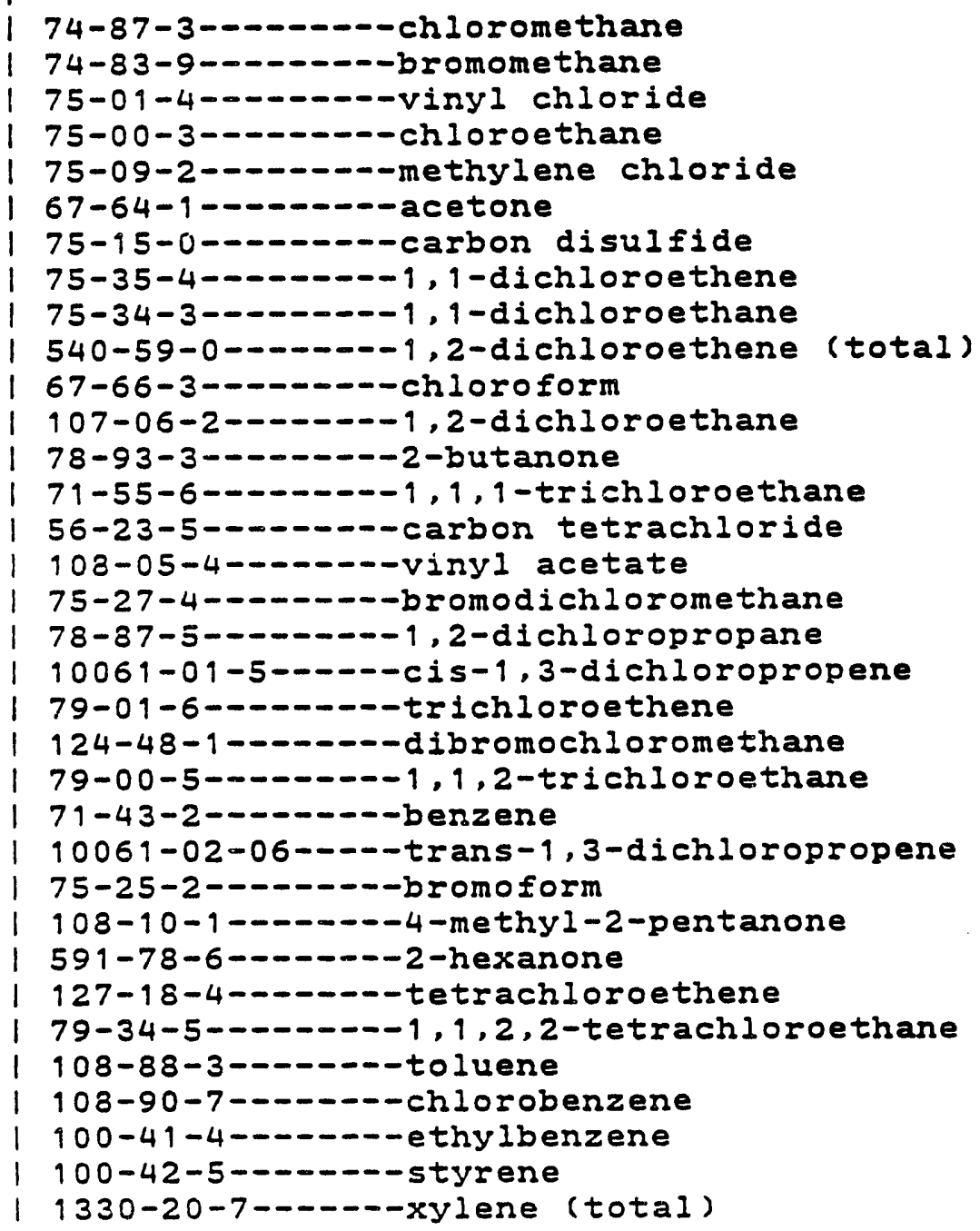

Reviewed by:

10.

10.

10.

90 .

5.00

10.

5.00

5.00

5.00

5.00

18.

5.00

10.

49.

5.00

10.

5.00

5.00

5.00

5.00

5.00

5.00

5.00

5.00

5.00

10.

10.

5.00

5.00

5.00

5.00

5.00

5.00

5.00 
VOLATILE ORGANICS ANALYSIS DATA SHEET

Request Number: OAL 94146

Procedure Number: 8240

Matrix: SOIL \& WATER

Series:

Frequency: ON REQUEST

Eustomer Name: SIEGRIST

$5 \mathrm{ML}$

Sample wt/vol:

Date Sampled: 19-Feb-1991 16:30

\% Moisture: not dec.

dec:

Material Description WATER

Number TICs found: 0
EPA SAMPLE NO.

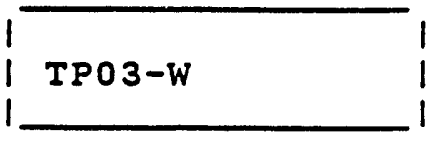

Charge Number: $\quad 33357130$

Lab Sample ID: 910228-060

Lab File ID: >G2111

Date Received 27-Feb-1991 14:30

Date Analyzed: 28-Feb-1991

Date of Report: 2-MAY-91

CONCENTRATION UNITS: (UG/L OF UG/KG) UG/L

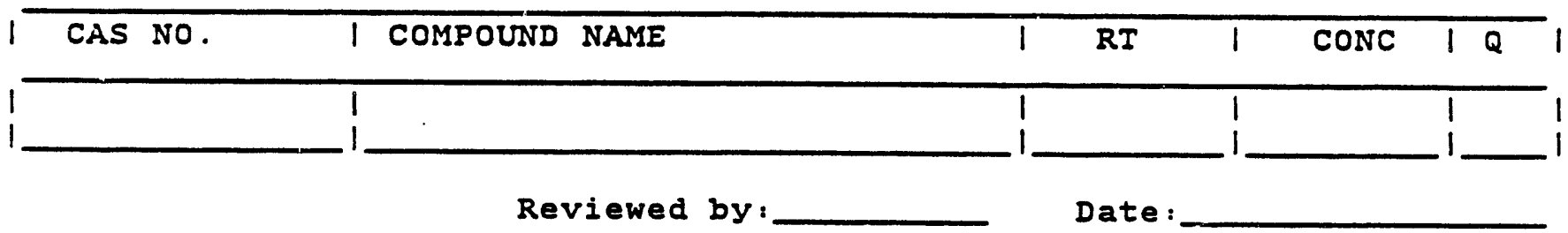


Semivolatile organic Analysis Data

EPA SAMPLE NO.

-ab Name: Oak Ridge National Lab

-ab code:

Case no: CLP

latrix: (soil/water) WATER

jample wt/vol: $\quad 150 \mathrm{ML}$

-eve 1: ( low/med) Low

\% Moisture: not dec. dec.

Extraction: (Sepf/cont/Sonc) SEPF

3PC Cleanup: $(Y / N) N$

pH: 8.86

COMPOUND

CAS NO.
Contract: NR

SAS NO: NR
TPO3-W

SDG NO: C425
Lab Sample ID: 910228-060

Lab File ID: >C3766

Date Received 28-Feb-1991

Date Analyzed: 25-Apr-1991

Date Extracted: 18-Mar-1991

Dilution Factor: $\quad 6.7$

CONCENTRATION UNITS:

(UG/L Or UG/KG) UG/L

Q

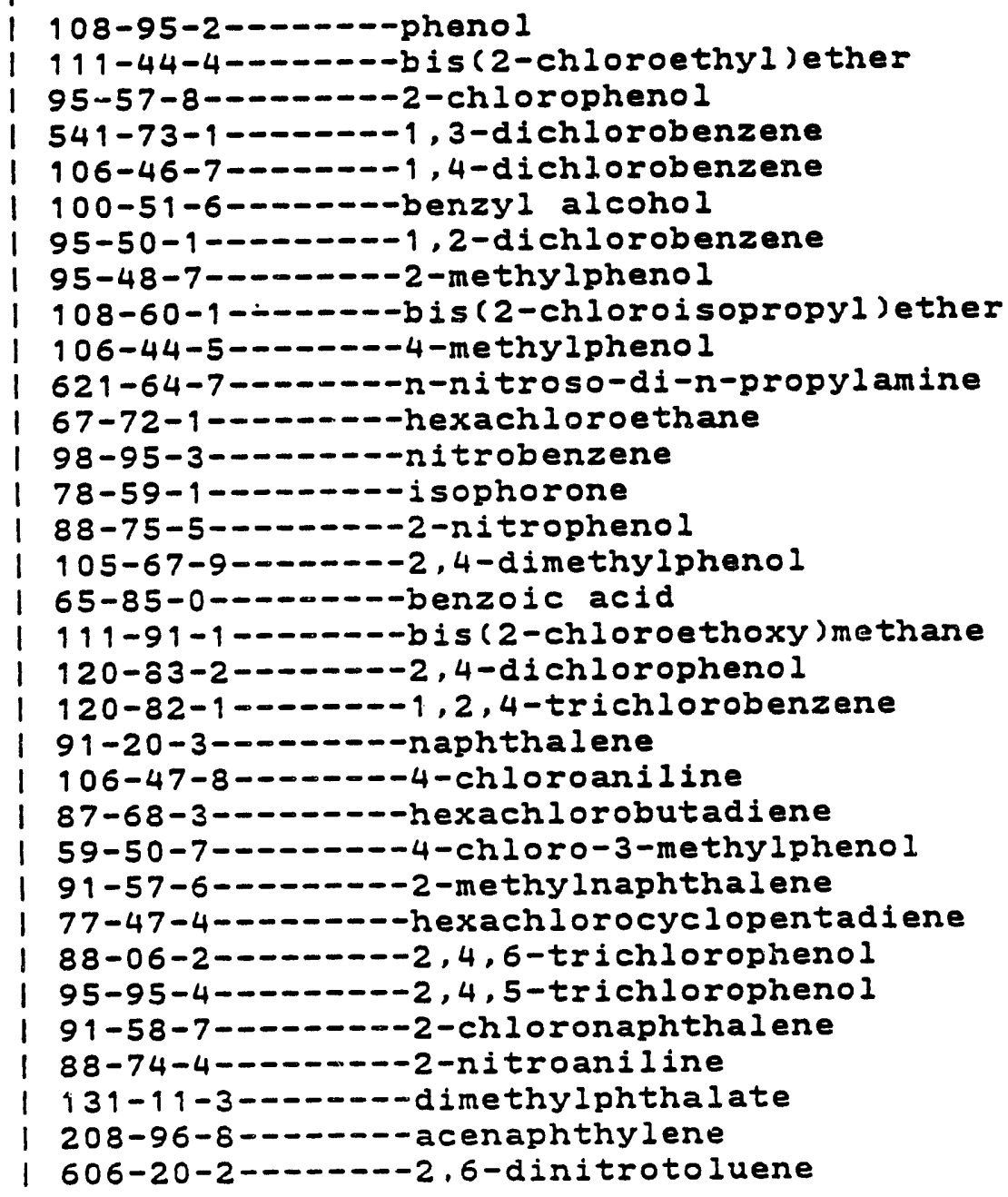

67.

67.

67.

67.

67.

67.

67.

67.

67.

67.

67.

67.

67.

67.

67.

67.

330 .

67.

67.

67.

67.

67.

67.

67 .

67.

67.

67.

330 .

67.

330 .

67.

67.

67. 
Semivolatile Organic Analysis Data

jab Name: Oak Ridge National Lab

¿ab Code:

Case no: CLP

latrix: (soil/water) WATER

sample wt/vol: $\quad 150 \mathrm{ML}$

jevel: (low/med) LOW

\% Moisture: not dec. dec.

Extraction: (Sepf/Cont/Sone) SEPF

3PC Cleanup: $(Y / N) N \quad$ pH: 8.86
Contract: NR

SAS NO: NR
EPA SAMPLE NO.

TP03-W

SDG NO: $C 425$

Lab Sample ID: 910228-060

Lab File ID: $\quad>C 3766$

Date Received 28-Feb-1991

Date Analyzed: 25-Apr-1991

Date Extracted: 18-Mar-1991

Dilution Factor: $\quad 6.7$

CONCENTRATION UNITS:

(UG/L OI UG/KG) UG/L

Q

CAS NO.

COMPOUND

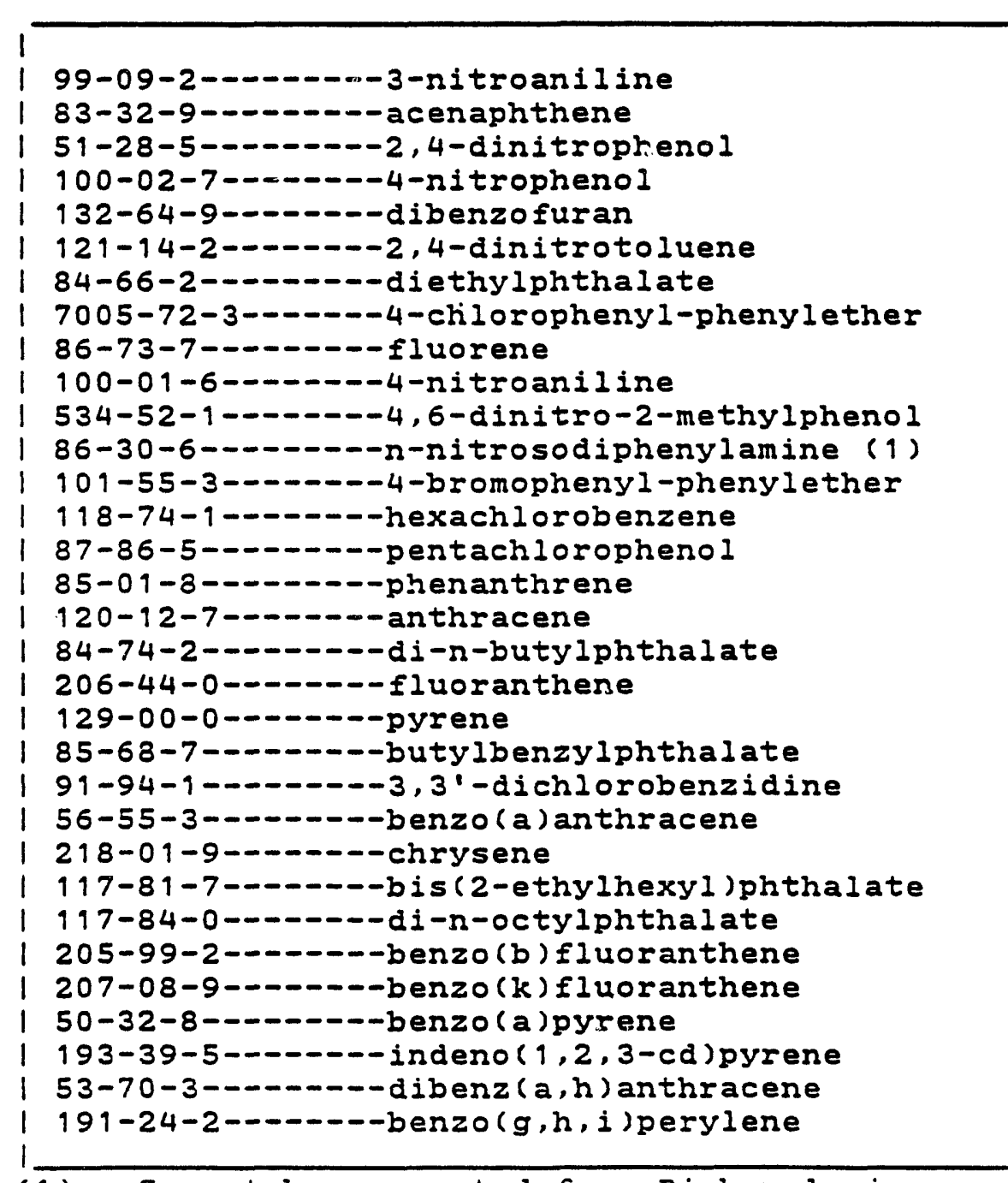

\begin{tabular}{|c|c|c|c|}
\hline 1 & & 1 & \\
\hline 1 & 330. & 1 & $U$ \\
\hline$i$ & 67. & 1 & $\mathrm{U}$ \\
\hline 1 & 330. & 1 & $U$ \\
\hline 1 & 330. & 1 & U \\
\hline 1 & 67. & 1 & $U$ \\
\hline 1 & 67. & 1 & U \\
\hline 1 & 67. & 1 & $U$ \\
\hline 1 & 67. & 1 & $U$ \\
\hline 1 & 67. & 1 & $U$ \\
\hline 1 & 330. & 1 & $U$ \\
\hline 1 & 330. & 1 & $U$ \\
\hline 1 & 67. & 1 & $U$ \\
\hline 1 & 67. & 1 & $U$ \\
\hline 1 & 67. & 1 & $U$ \\
\hline 1 & 330. & 1 & $U$ \\
\hline 1 & 67 & 1 & $U$ \\
\hline 1 & 67. & 1 & $U$ \\
\hline 1 & 67. & 1 & $U$ \\
\hline 1 & 67. & 1 & U. \\
\hline$i$ & 67. & 1 & $U$ \\
\hline 1 & 120. & 1 & B \\
\hline 1 & 130. & 1 & $U$ \\
\hline 1 & 67 & 1 & $U$ \\
\hline$i$ & 67. & 1 & U \\
\hline 1 & 67. & 1 & $U$ \\
\hline 1 & 67. & 1 & $U$ \\
\hline 1 & 67. & 1 & $U$ \\
\hline 1 & 67. & 1 & $U$ \\
\hline 1 & 67. & 1 & $U$ \\
\hline 1 & 67. & 1 & U \\
\hline 1 & 67. & 1 & $U$ \\
\hline 1 & 67. & 1 & $U$ \\
\hline
\end{tabular}

Reviewed by:

Date : 


\section{Semivolatile organic Analysis Data}

Request Number: OAL94146

?rocedure Number: $\mathbf{8 2 4 0}$

Matrix: SOIL \& WATER

jeries :

Frequency: ON REQUEST

Charge Number:

33357130

justomer Name: SIEGRIST

Lab Sample ID: 910228-060

sample wt/vol:

$150 \mathrm{ML}$

Jate Sampled: 19-Feb-1991 16:30

dec:

: Moisture: not dec.

deces

saterial Description WATER

iumber TICs found: 0
Lab File ID: >C3766

Date Received 27-Feb-1991 14:30

Date Analyzed: 25-Apr-1991

Date of Report: 2-MAY-91

CONCENTRATION UNITS: (UG/L or UG/KG) UG/L
EPA SAMPLE NO.

\section{TP03-W}

1.

\begin{tabular}{|c|c|c|c|c|c|}
\hline CAS NO. & I COMPOUND NAME & $\mathbf{R T}$ & 1 & CONC & 1 \\
\hline 1 & 1 & 1 & 1 & & 1 \\
\hline
\end{tabular}




\section{VCLATILE ORGANICS ANALYSIS DATA SHEET}

Lab Name: Oak Ridge National Lab Lab Code:

Case nO: ORNL

Matrix: (soil/water) SoIL

Sample wt/vol:

56

Level: (low/med) LOW

\% Moisture: not dec.

Column: (pack/cap) CAP
Contract: NR

SAS NO: NR
EPA SAMPIEE NO.

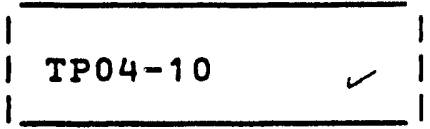

SDG NO: 0308

Lab Sample ID: 910228-061

Lab File ID: $\quad>01198$

Date Received 28-Feb-1991

Date Analyzed: 8-Mar-1991

Dilution Factor: $\quad 1.0$

CONCENTRATION UNITS:

CAS NO. COMPOUND (UG/L OY UG/KG) UG/KG

Q

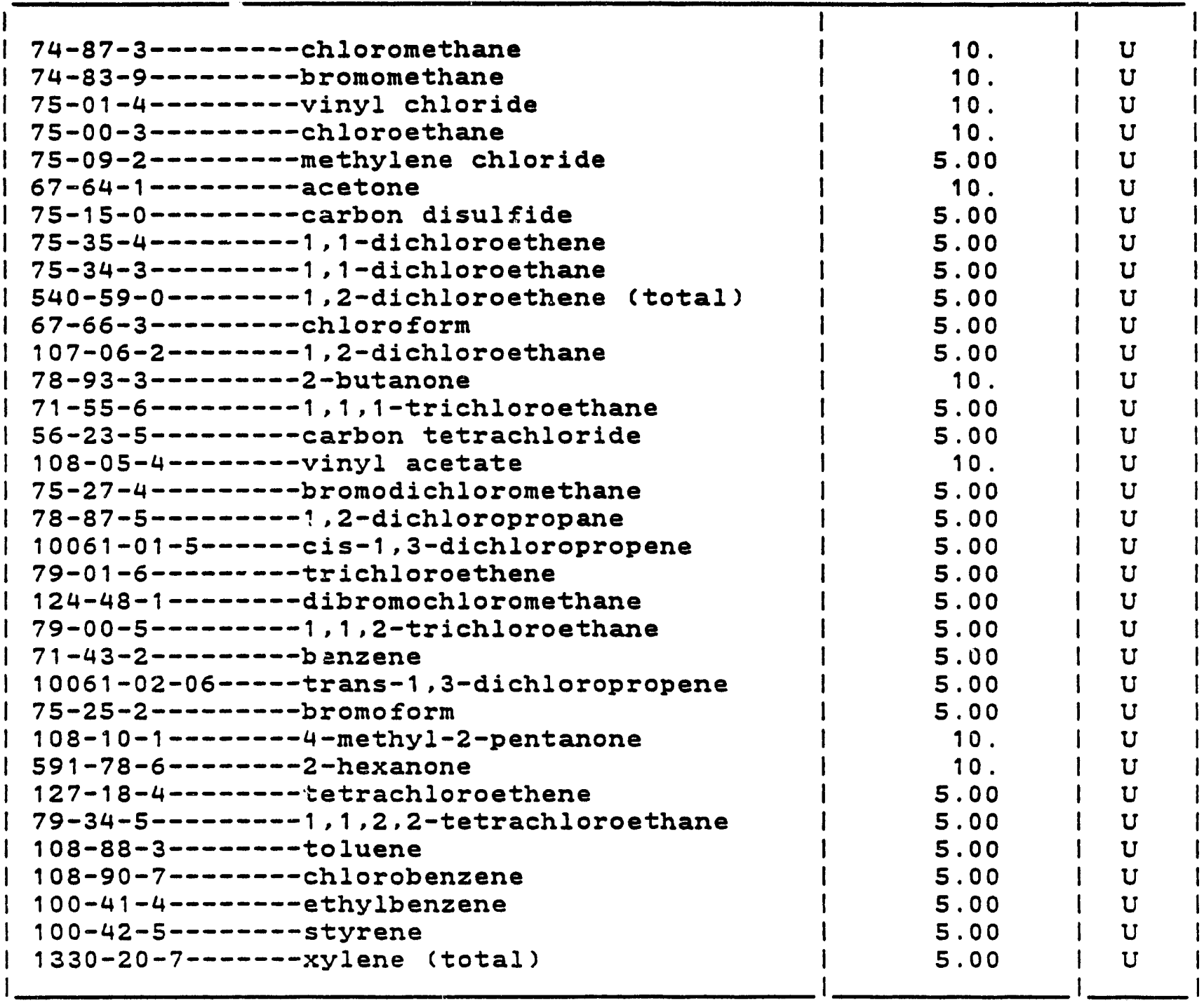

Reviewed by:

Date : 
Semivolatile Organic Analysis Data

Lab Name: Oak Ridge National Lab jab Code:

Case no: NR

ratrix: (soil/water) SOIL

sample wt/vol: $\quad 32.0 \mathrm{G}$

Level: (low/med) Low

\% Moisture: not dec. dec.

Extraction: (Sepf/Cont/Sone) sonc

zPC cleanup: $(Y / N) N \quad \mathrm{NH}: \mathrm{NR}$
Contract: NR

SAS NO: NR

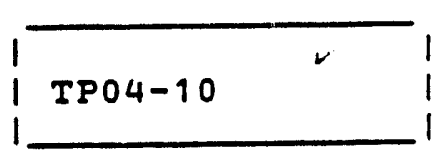

SDG NO: C319

Lab Sample ID: 910228-061

Lab File ID: >C3565

Date Received 28-Feb-1991

Date Analyzed: 20-Mar-1991

Date Extracted: 8-Mar-1991

Dilution Factor: $\quad 1.0$

CONCENTRATION UNITS:

CAS NO. COMPOUND (UG/L OI UG/KG) UG/KG

Q

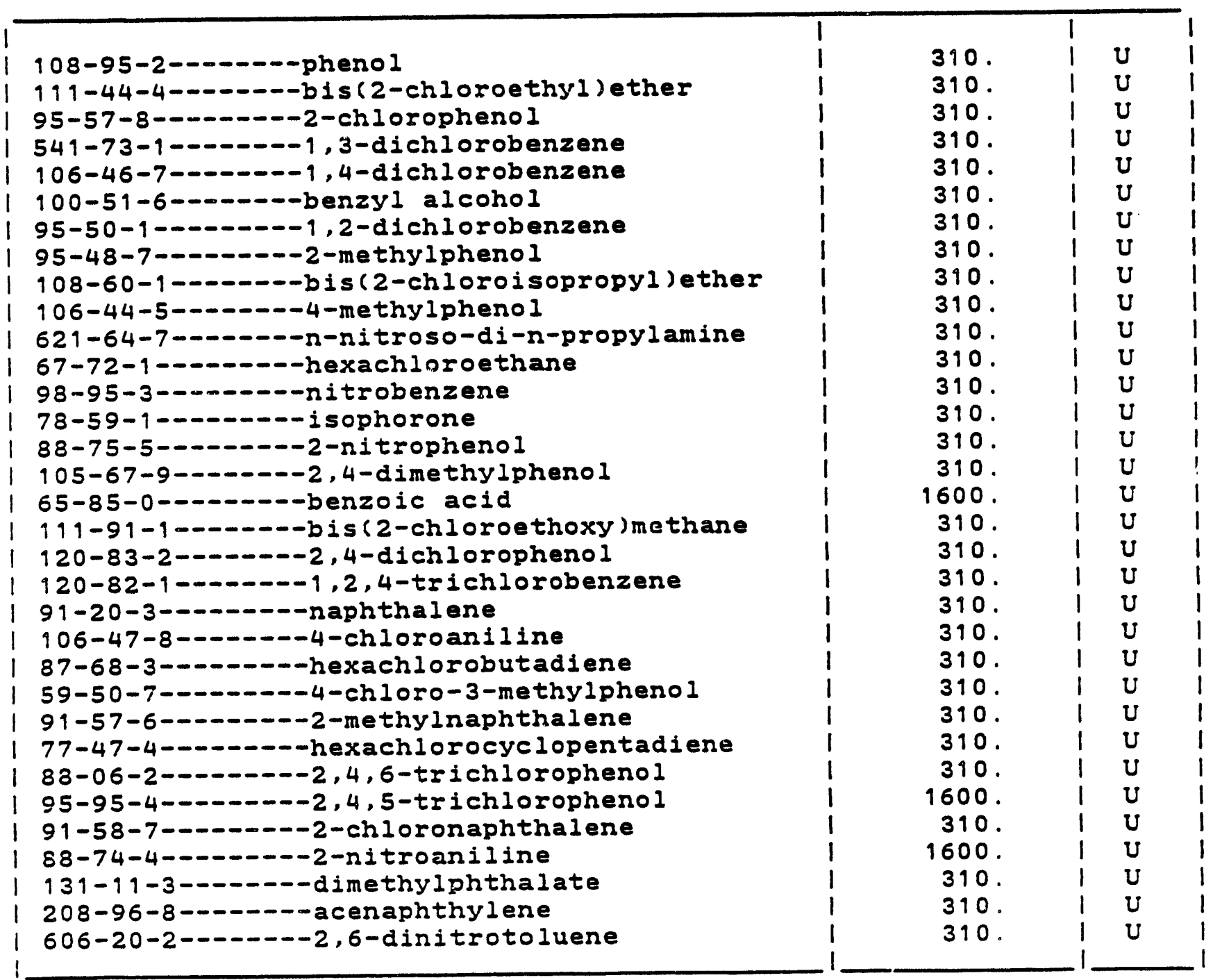


Semivolatile Organic Analysis Data

Lab Nams: Oak Ridge National Lab

Lab Code:

Case no: NR

Matrix: (soil/water) soIL

Sample wtivol: $\quad 32.0 \mathrm{G}$

Level: (low/med) LOW

\% Moisture, not dec. dec.

Extraction: (Sepf/Cont/Sone) soNC

GPC Cleanup: $(Y / N) N$

pH : NR
Contract: NR

SAS NO: NR
EPA SAMPLE NO.

TP04-10

SDG NO: C319

Lab Sample ID: 9102:8-061

Lab File ID: $>C 3565$

Date Received 28-Feb-1991

Date Analyzed: 20-Mar-1991

Date Extracted: 8-Mar-1999

Dilution Factor: $\quad 1.0$

CONCENTRATION UNITS :

CAS NO. COMPOUND

Q

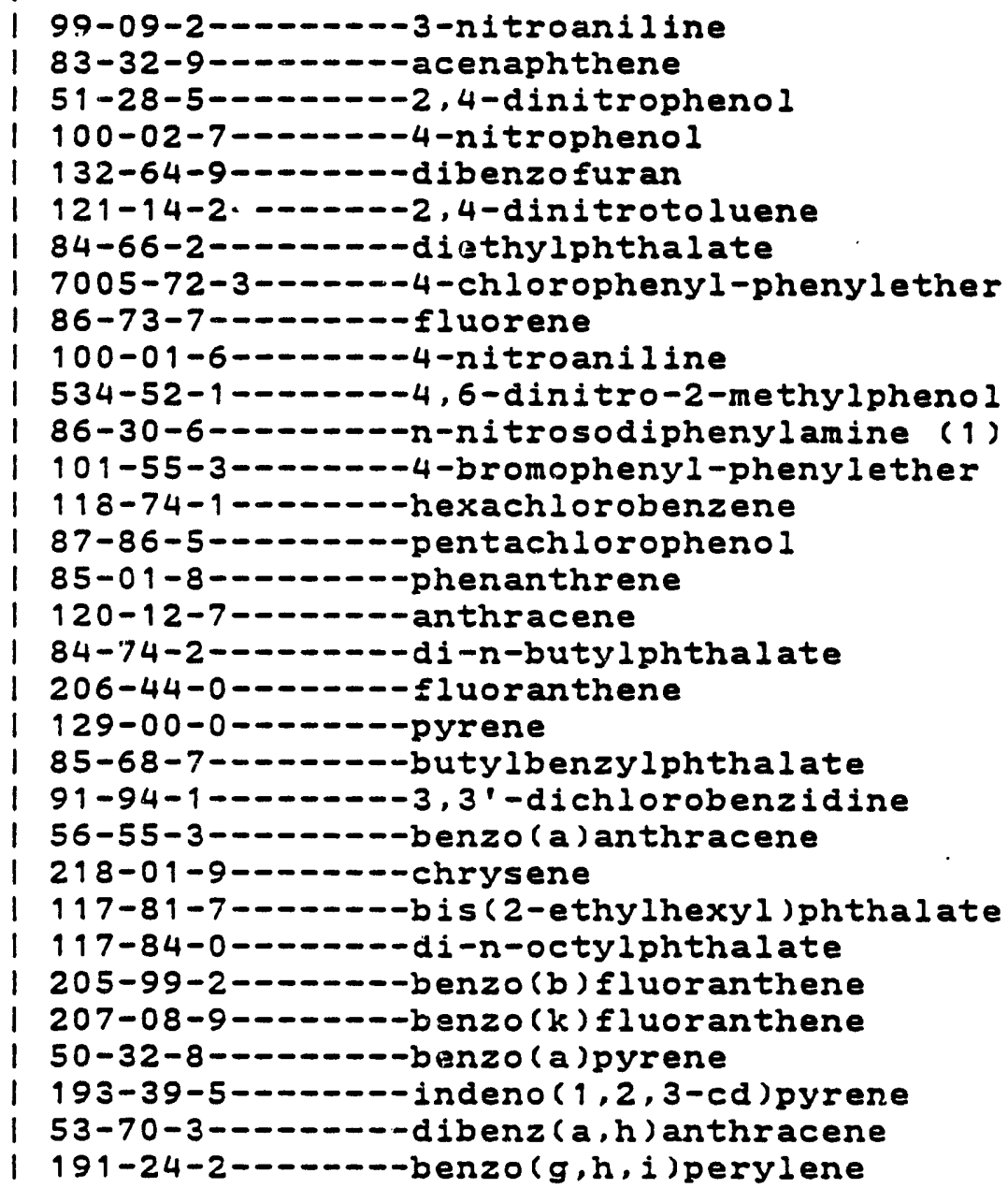


Semivolatile Organic Analysis Data

Request Number: OAL 94146

EPA SAMPLE NO.

Procedure Number, 8240 Matrix: SOIL \& WATER

Series:

Frequency; ON REQUEST

Charge Number:

33357130

Zustomer Name: SIEGRIST

Lab Sample ID: 910228-061

Sample wt/vol: $32.0 \mathrm{G}$

Lab File ID: >C3565

Jate Sampled: 20-Feb-1991 12:30

Date Received 27-Feb-1991 14:30

7. Moisture: not dec.

dec:

Date Analyzed: 20-MaI-1991

Yaterial Description soIL

Date of Report: 2-MAY-91

Number TICs found: 0

CONCENTRATION UNITS :

(UG/L OI UG/KG) UG/KG

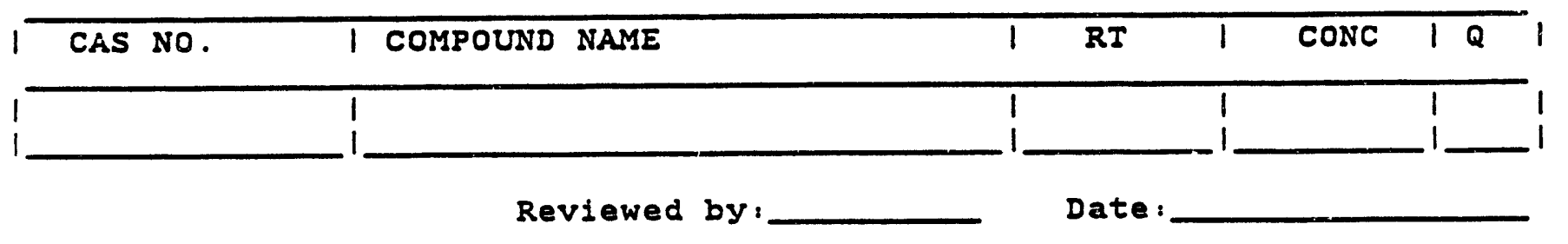


¿ab Name: Oak Ridge National Lab -ab Code:

Case תO: ORNL

latrix: (soil/water) soIL

jample wt/vol:

$5 \mathbf{G}$

-eve 1: ( low/med) Low

: Moisture: not dec.

zolumn: (pack/cap) PACK
Contract: NR

SAS NO: NR

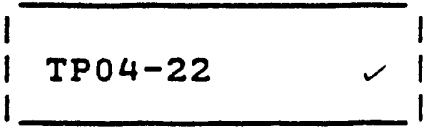

SDG NO: G304 $(:: 2$
Lab Sample ID: 910228-062

Lab File ID: >G2143

Date Received 28-Feb-1991

Date Analyzed: 4-Mar-1991

Dilution Factor: $\quad 1.0$

CAS NO.

COMPOUND

CONCENTRAIION UNITS:

(UG/L or UG/KG) JG/KG

Q

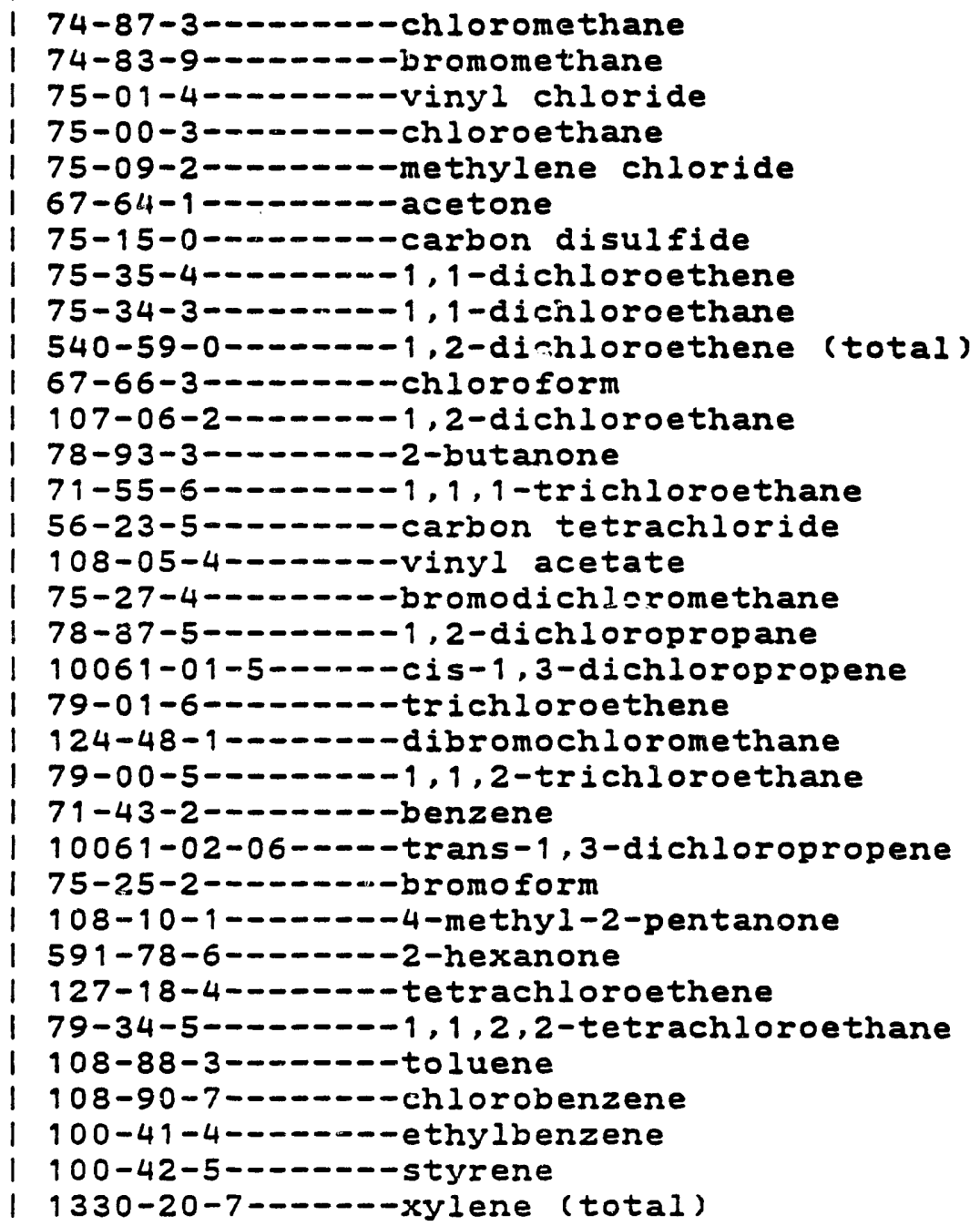

\section{0.}

10 .

10 .

10 .

1.00

160 .

5.00

5.00

5.00

5.00

5.00

5.00

10 .

5.00

5.00

10.

5.00

5.00

5.00

5.00

5.00

5.00

5.00

5.00

5.00

10.

10 .

5.00

5.00

5.00

5.00

5.00

5.00

5.00 


\section{VOLATILE ORGANICS ANALYSIS DATA SHEET}

Reguest Number: OAL94146

Procedure Number: 8240

Matrix: SOIL \& WATER

EPA SAMPLE NO.

Series:

Frequency: ON REQUEST

Charge Number:

33357130

Customer Name: SIEGRIST

Lab Sample ID: 910228-062

Sample wt/vol:

5 G

Lab File ID: >G2143

Date Sampled: 20-Feb-1991 12:40

Date Received 27-Feb-1991 14:30

\% Moisture: not dec.

dec:

Date Analyzed: 4-Mar-1991

Material Description soIL

Date of Report: 2-MAY-91

Number IICs found: 0

CONCENTRATION UNITS:

(UG/L Or UG/KG) UG/KG

\begin{tabular}{|c|c|c|c|c|c|}
\hline I CAS NO. & I COMPOUND NAME & $\overline{R T}$ & 1 & CONC & \\
\hline 1 & 1 & 1 & 1 & & 1 \\
\hline
\end{tabular}


Semivolatile Organic Analysis Data

EPA SAMPLE NO.

iab Name: Oak Ridge National Lab

iab Code:

Case no: NR

Yatrix: (soil/water) soIL

sample wt/vol: $\quad 32.0 \mathrm{G}$

Level: (low/med) Low

\% Moisture: not dec. dec.

Extraction: (sepf/Cont/sonc) sonc

JPC Cleanup: $(Y / N) N$

PH: NR
Contract: NR

SAS NO: NR

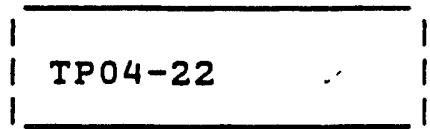

SDG NO: 6319 志: N.

Lab Sample ID: 910228-062

Lab File ID: >C3558

Date Received 28-Feb-1991

Late Aralyzed: 19-Mar-1991

Date Extracted: 8-Mar-1991

Dilution Factor: 100.

CONCENTRATION UNITS:

CAS NO. COMPOUND (UG/L OY UG/KG) UG/KG

Q

31.

31.

31.

31.

39.

31.

31.

31.

31.

39.

31.

31.

31.

31.

31.

31.

160.

31.

31.

31.

31.

31.

31.

31.

31.

31.

31.

160.

31.

160.

31.

31.

31.

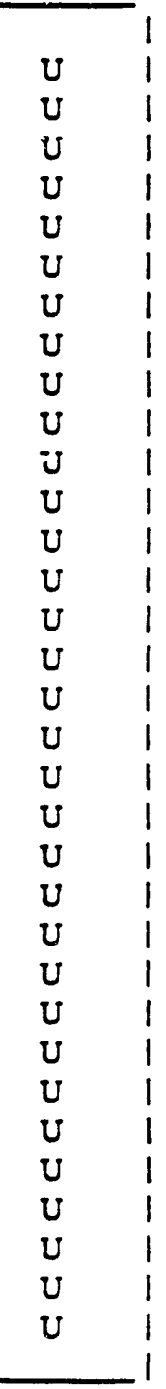


Semivolatile organic Analysis Data

Lab Name: Oak Ridge National Lab

Lab Code:

Case no: NR

Matrix: (soil/water) SOIL

Contract: NR

SAS NO: NR sample wt/vol: $\quad 32.0 \mathrm{G}$

Level: (low/med) Low

\% Moisture: not dec. dec.

Extraction: (Sepf/Cont/Sonc) SONC
Lab Sample ID: 910228-062

Lab File ID: $>C 3558$

Date Received 28-Feb-1991

Date Analyzed: 19-Mar-1991

Date Extracted: 8-Mar-1991

Dilution Factor: 100.

GPC Cleanup: $(Y / N) N \quad \mathrm{NH}: \mathrm{NR}$

CONCENTRATION UNITS:

CAS NO.

COMPOUND

(UG/L or UG/KG) UG/KG

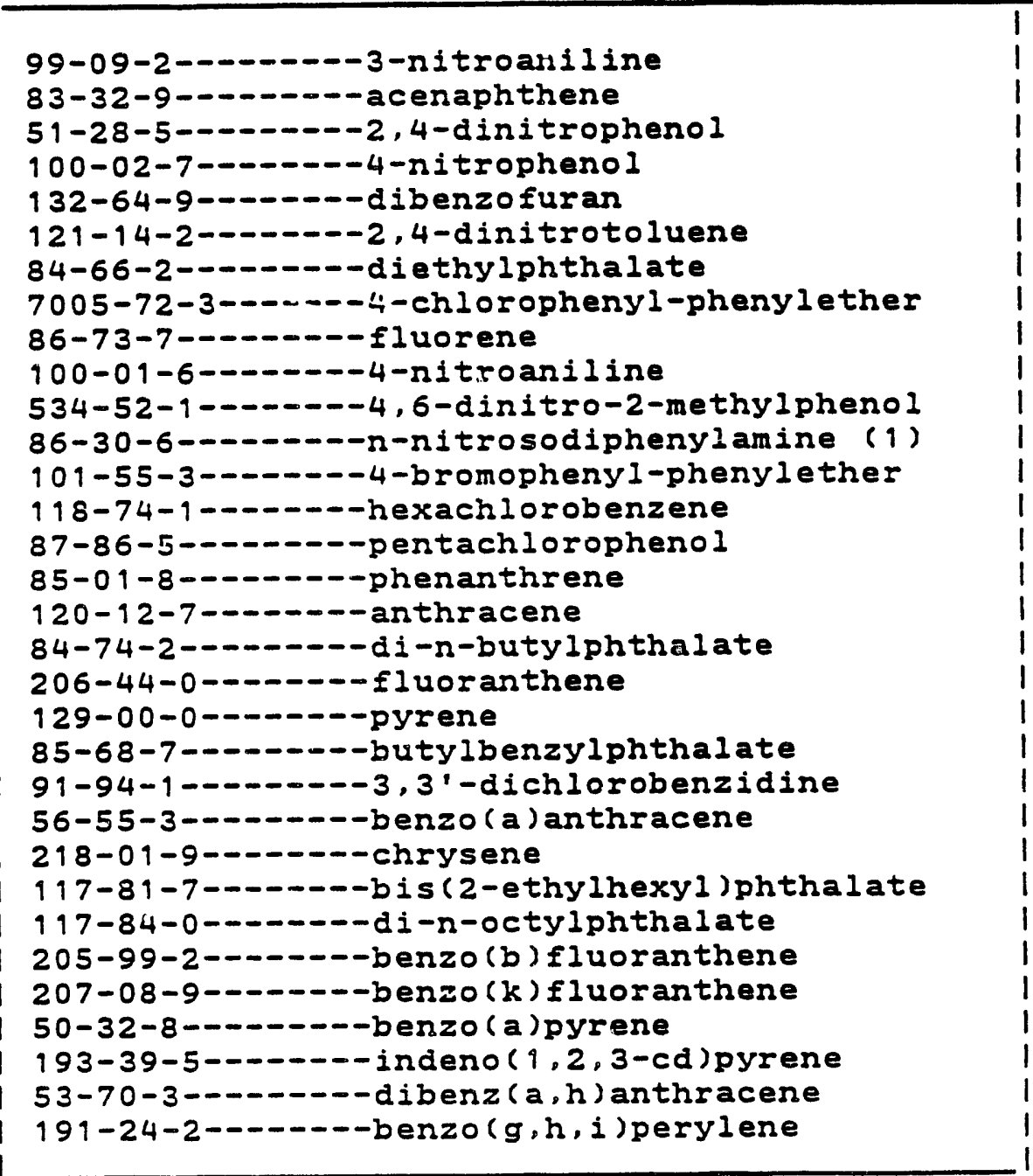

(1) - Cannot be separated from Diphenylamine

Reviewed by:

\begin{tabular}{|c|c|c|}
\hline & 1 & \\
\hline 160. & 1 & $U$ \\
\hline 31 & 1 & $U$ \\
\hline 160. & 1 & $U$ \\
\hline 960. & 1 & $U$ \\
\hline 31. & 1 & $U$ \\
\hline 31. & 1 & $U$ \\
\hline 31. & 1 & $U$ \\
\hline 31. & 1 & $U$ \\
\hline 31. & 1 & $U$ \\
\hline 960. & 1 & $U$ \\
\hline 160. & 1 & $U$ \\
\hline 31. & 1 & $U$ \\
\hline 31. & 1 & $U$ \\
\hline 31. & 1 & $U$ \\
\hline 160. & 1 & U \\
\hline 31. & 1 & $U$ \\
\hline 31. & 1 & U \\
\hline 31. & 1 & U \\
\hline 31. & 1 & $U$ \\
\hline 31. & 1 & $U$ \\
\hline 31. & 1 & U \\
\hline 63. & 1 & U \\
\hline 31. & 1 & $U$ \\
\hline 31. & 1 & $U$ \\
\hline 31. & 1 & $\mathrm{U}$ \\
\hline 39. & 1 & $U$ \\
\hline 31. & 1 & $U$ \\
\hline 39. & 1 & U \\
\hline 31. & 1 & $\mathrm{U}$ \\
\hline 31. & 1 & U \\
\hline 31. & 1 & $U$ \\
\hline 31. & 1 & $U$ \\
\hline
\end{tabular}

Date : 
Semivolatile Organic Analysis Data

Request Number: OAL94146

Procedure Number: 8240 . Matrix: SOIL \& WATER

EPA SAMPLE NO.

Series:

Frequency: ON REQUEST

Charge Number:

33357130

Iustomer Name: SIEGRIST

Lab Sample ID: 910228-062

Sample wt/vol:

$32.0 \mathrm{G}$

Lab File ID: $>C 3558$

Date Sampled: $20-F e b-199112: 40$

Date Received 27-Feb-1991 14:30

\% Moisture: not dec.

dec:

Date Analyzed: 19-Mar-1991

Material Description SoIL

Date of Report: 2-MAY-91

Number TICs found: 0

CONCENTRATION UNITS:

(UG. 2 OP UG/KG) UG/KG

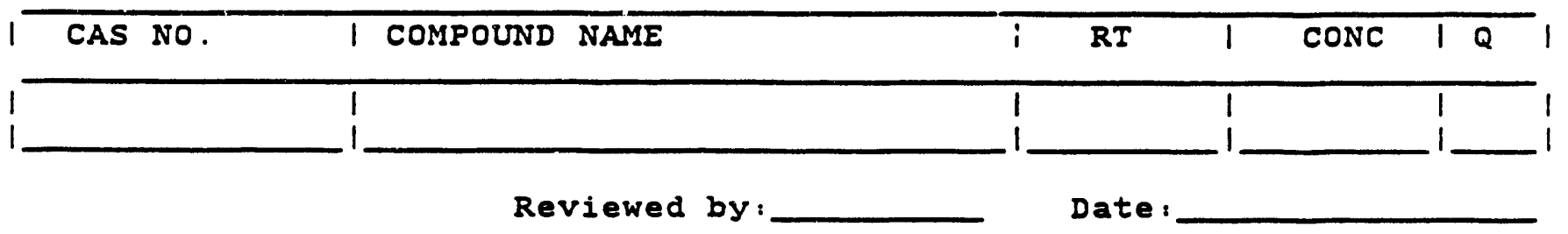




\section{VOLATILE ORGANICS ANALYSIS DATA SHEET}

EPA SAMPLE NO.

Lab Name: Oak Ridge National Lab

Lab Code:

Case nO: ORNL

Matrix: (soil/water) soIL

Sample wt/vol:

$5 \mathbf{G}$

Level: (low/med) Low

\% Moisture: not dec.

Column: (pack/cap) CAP

CAS NO.

COMPOUND
Contract: NR

SAS NO: NR

SDG NO: 0308

Lab Sample ID: 910228-063

Lab File ID: $\quad>01199$

Date Received 28-Feb-1991

Date Aralyzed: 8-Mar-1991

Dilution Factor: $\quad 1.0$ 74-87-3-------chloromethane

1 74-83-9---n---bromomethane

1 75-01-4-------vinyl chloride

| 75-00-3-...--nchloroethane

I 75-09-2--------methylene chloride

| 67-64-1----n---acetone

1 75-15-0-------carbon disulfide

| 75-35-4-n-n---1,1-dichloroethene

1 75-34-3--.---- 1, 1-dichloroethane

1 540-59-0------ 1,2-dichloroethene (total)

I 67-66-3---n---chloroform

1 107-06-20------1,2-dichloroethane

| 78-93-3-------2-butanone

1 71-55-6-- - - - 1, 1, 1-trichloroethane

1 56-23-5--------carbon tetrachloride

1 108-05-4------vinyl acetate

| 75-27-4--n----bromodichloromethane

1 78-87-5-------1,2-dichloropropane

I 10061-01-5-----cis-1,3-dichloropropene

1 79-01-6-------trichloroethene

| 124-48-1------dibromochloromethane

1 79-00-5--.--- 1, 1,2-trichloroethane

1 71-43-2-------benzene

| 10061-02-06----trans-1,3-dichloropropene

I 75-25-2--------bromoform

| 108-10-1-..--- -4-methy 1-2-pentanone

I 591-78-6--..-- 2-hexanone

| 127-18-4-------tetrachloroethene

I 79-34-5--------1, 1,2,2-tetrachloroethane

| 108-88-3-------toluene

I 108-90-7-------chlorobenzene

| 100-41-4-------ethylbenzene

I 100-42-5------styrene

1 1330-20-7------xylene (total)

\begin{tabular}{|c|c|c|c|c|}
\hline & 1 & & 1 & \\
\hline & 1 & 90. & 1 & U \\
\hline & 1 & 90. & 1 & $U$ \\
\hline & 1 & 10. & 1 & $U$ \\
\hline & 1 & 90. & 1 & $U$ \\
\hline & 1 & 5.00 & 1 & U \\
\hline & 1 & 10 & 1 & U \\
\hline & 1 & 5.00 & 1 & U \\
\hline & 1 & 5.00 & 1 & $U$ \\
\hline & 1 & 5.00 & 1 & U \\
\hline total) & 1 & 5.00 & 1 & $U$ \\
\hline & 1 & 5.00 & 1 & U \\
\hline & 1 & 5.00 & 1 & $U$ \\
\hline & 1 & 10. & 1 & U \\
\hline & 1 & 5.00 & 1 & $U$ \\
\hline & 1 & 5.00 & 1 & U \\
\hline & 1 & 10. & 1 & $U$ \\
\hline & 1 & 5.00 & 1 & $U$ \\
\hline & 1 & 5.00 & 1 & $U$ \\
\hline ene & $!$ & 5.00 & 1 & U \\
\hline & 1 & 5.00 & 1 & U \\
\hline & 1 & 5.00 & 1 & U \\
\hline de & 1 & 5.00 & 1 & U \\
\hline & 1 & 5.00 & 1 & U \\
\hline pene & 1 & 5.00 & 1 & U \\
\hline & 1 & 5.00 & 1 & U \\
\hline & 1 & 10. & 1 & U \\
\hline & 1 & 10. & 1 & U \\
\hline & 1 & 5.00 & 1 & U \\
\hline thane & 1 & 5.00 & 1 & U \\
\hline & 1 & 5.00 & 1 & U \\
\hline & 1 & 5.00 & 1 & U \\
\hline & 1 & 5.00 & 1 & U \\
\hline & 1 & 5.00 & 1 & U \\
\hline & 1 & 5.00 & 1 & $U$ \\
\hline
\end{tabular}

Date : 


\section{VOLATILE ORGANICS ANALYSIS DATA SHEET}

Request Number: OAL94146

Procedure Number: 8240

Matrix: SOIL \& WATER
EPA SAMPLE NO.

TP04-65

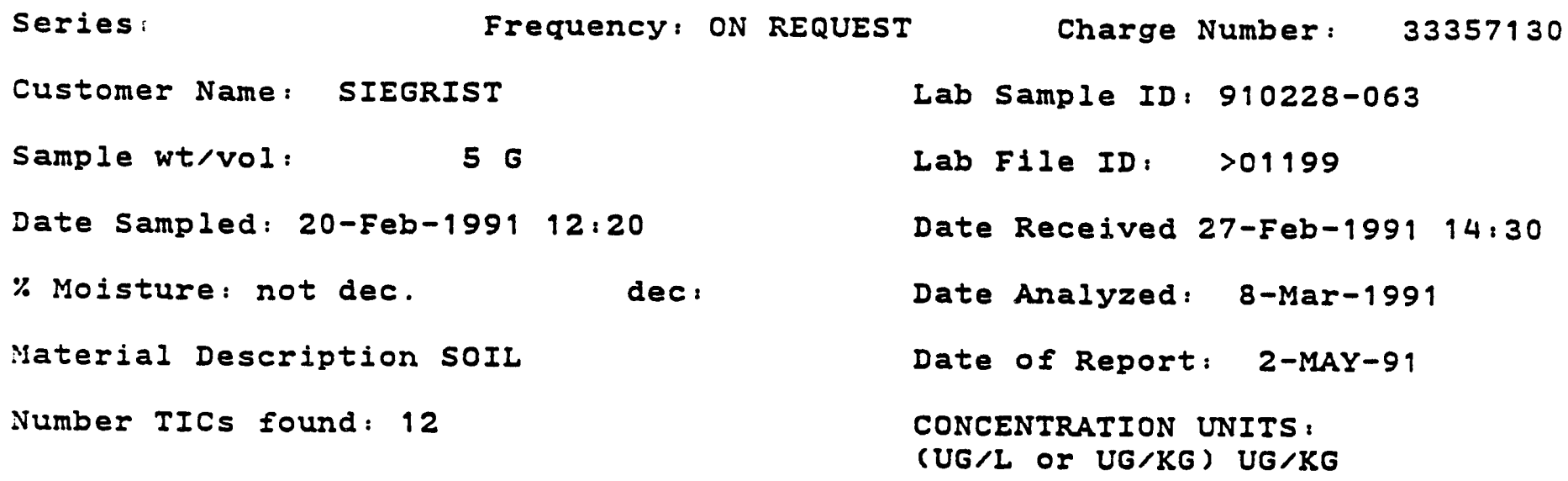

\begin{tabular}{|c|c|c|c|c|c|c|c|}
\hline CAS NO. & I COMPOUND NAME & 1 & $\mathbf{R T}$ & 1 & CONC & 1 & $\mathbf{Q}$ \\
\hline 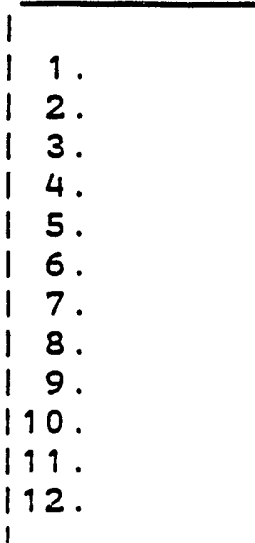 & $\begin{array}{l}\text { I UNKNOWN } \\
\text { I UNKNOWN } \\
\text { I UNKNOWN } \\
\text { I UNKNOWN } \\
\text { I UNKNOWN HYDROCARBON } \\
\text { I UNKNOWN } \\
\text { I UNKNOWN HYDROCARBON } \\
\text { I UNKNOWN } \\
\text { I UNKNOWN } \\
\text { I UNKNOWN } \\
\text { I UNKNOWN } \\
\text { I UNKNOWN }\end{array}$ & $\begin{array}{l}1 \\
1 \\
1 \\
1 \\
1 \\
1 \\
1 \\
1 \\
1 \\
1 \\
1 \\
1 \\
1\end{array}$ & $\begin{array}{r}2.38 \\
16.01 \\
19.03 \\
20.31 \\
20.52 \\
21.01 \\
22.43 \\
22.60 \\
22.74 \\
27.70 \\
28.29 \\
28.47\end{array}$ & $\begin{array}{l}1 \\
1 \\
1 \\
1 \\
1 \\
1 \\
1 \\
1 \\
1 \\
1 \\
1 \\
1 \\
1\end{array}$ & $\begin{array}{l}990 . \\
190 . \\
250 . \\
140 . \\
150 . \\
230 . \\
150 . \\
150 . \\
210 . \\
200 . \\
150 . \\
140 .\end{array}$ & $\begin{array}{l}1 \\
1 \\
1 \\
1 \\
1 \\
1 \\
1 \\
1 \\
1 \\
1 \\
1 \\
1 \\
1\end{array}$ & $\begin{array}{l}\mathrm{J} \\
\mathrm{J} \\
\mathrm{J} \\
\mathrm{J} \\
\mathrm{J} \\
\mathrm{J} \\
\mathrm{J} \\
\mathrm{J} \\
\mathrm{J} \\
\mathrm{J} \\
\mathrm{J}\end{array}$ \\
\hline
\end{tabular}


Semivolatile organic Analysis Data

Lab Name: Oak Ridge National Lab

Lab Code:

Case no: NR
Matrix: (soil/water) soIL

Sample wt/vol: $32.0 \mathrm{G}$

Level: (low/med) Low

\% Moisture: not dec. dec.

Extraction: (Sepf/Cont/Sonc) sonc

SPC Cleanup: $(Y / N) N$

PH : NR
Contract: NR
EPA SAMPLE NO.

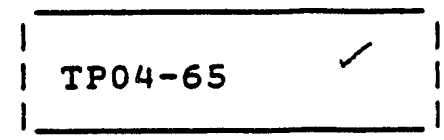

SAS NO: NR

SDG NO: C319

Lab Sample ID: 910228-063

Lab File ID: $\quad>C 3560$

Date Received 28-Feb-1991

Date Analyzed: 19-Mar-1991

Date Extracted: 8-Mar-1991

Dilution Factor: 100.

CONCENTRATION UNITS:

CAS NO.

COMPOUND

(UG/L Or UG/KG) UG/KG

108-95-2-------phenol

I 111-44-4--n---bis(2-chloroethyl)ether

1 95-57-8-------2-chlorophenol

I 541-73-1------1,3-dichlorobenzene

1 106-46-7-------1,4-dichlorobenzene

I 100-51-6-------benzyl alcohol

1 95-50-1-------1,2-dichlorobenzene

I 95-48-7--.----2-methylphenol

$1908-60-1-----b$ is (2-chloroisopropyl)ether

1 106-44-5-..---4-methylphenol

1 621-64-7-..---n-nitroso-di-n-propylamine

1 67-72-1---.----hexachloroethane

1 98-95-3---.--nitrobenzene

1 78-59-1--.-----isophorone

| 83-75-5--.---2-nitrophenol

I 905-67-9-------2,4-dimethylphenol

1 65-85-0-------benzoic acid

$1119-91-1-----b$ is (2-chloroethoxy) methane

1 120-83-2--.----2,4-dichlorophenol

| $120-82-1-\ldots---1,2,4-t r i c h l o r o b e n z e n e$

1 99-20-3----n--naphthalene

1 106-47-8-------4-chloroaniline

1 87-68-3-------hexachlorobutadiene

| 59-50-7-..--.-4-chloro-3-methylphenol

1 91-57-6--------2-methylnaphthalene

1 77-47-4------hexachlorocyclopentadiene

I 88-06-2---.---2,4,6-trichlorophenol

1 95-95-4--.-----2,4,5-trichlorophenol

1 91-58-7--.-.---2-chloronaphthalene

I 88-74-4-m-----2-nitroaniline

1 131-19-3--.----dimethylphthalate

1 208-96-8-..----acenaphthylene

606-20-2-n----2,6-dinitrotoiuene

31.

31.

39.

31.

31.

31.

31.

31.

39.

31.

31.

31.

31.

31.

31.

39.

160 .

31.

39.

39.

31.

39.

\section{1.}

31.

31.

31.

31.

160.

31.

160.

31.

31.

39. 
Semivolatile Organic Analysis Data

EPA SAMPLE NO.

Lab Name: Oak Ridge National Lab Contract: NR

TPO4-65

Lab Code: Case no: NR

SAS NO: NR

SDG NO: $C 319$

Yatrix: (soil/water) soIl

Lab Sample ID: 910228-063

Sample wt/vol: $\quad 32.0 \mathrm{G}$

Lab File ID: $\quad>C 3560$

Level: (low/med) Low

Date Received 28-Feb-1991

\% Moisture: not dec.

dec.

Date Analyzed: 19-Mar-1991

Extraction: (Sepf/Cont/Sonc) SONC

Date Extracted: 8-Mar-1991

IPC Cleanup: $(Y / N) N \quad$ PH: NR

Dilution Factor: $\quad 100$.

CAS NO.

COMPOUND

CONCENTRATION UNITS :

(UG/L or UG/KG) UG/KG Q

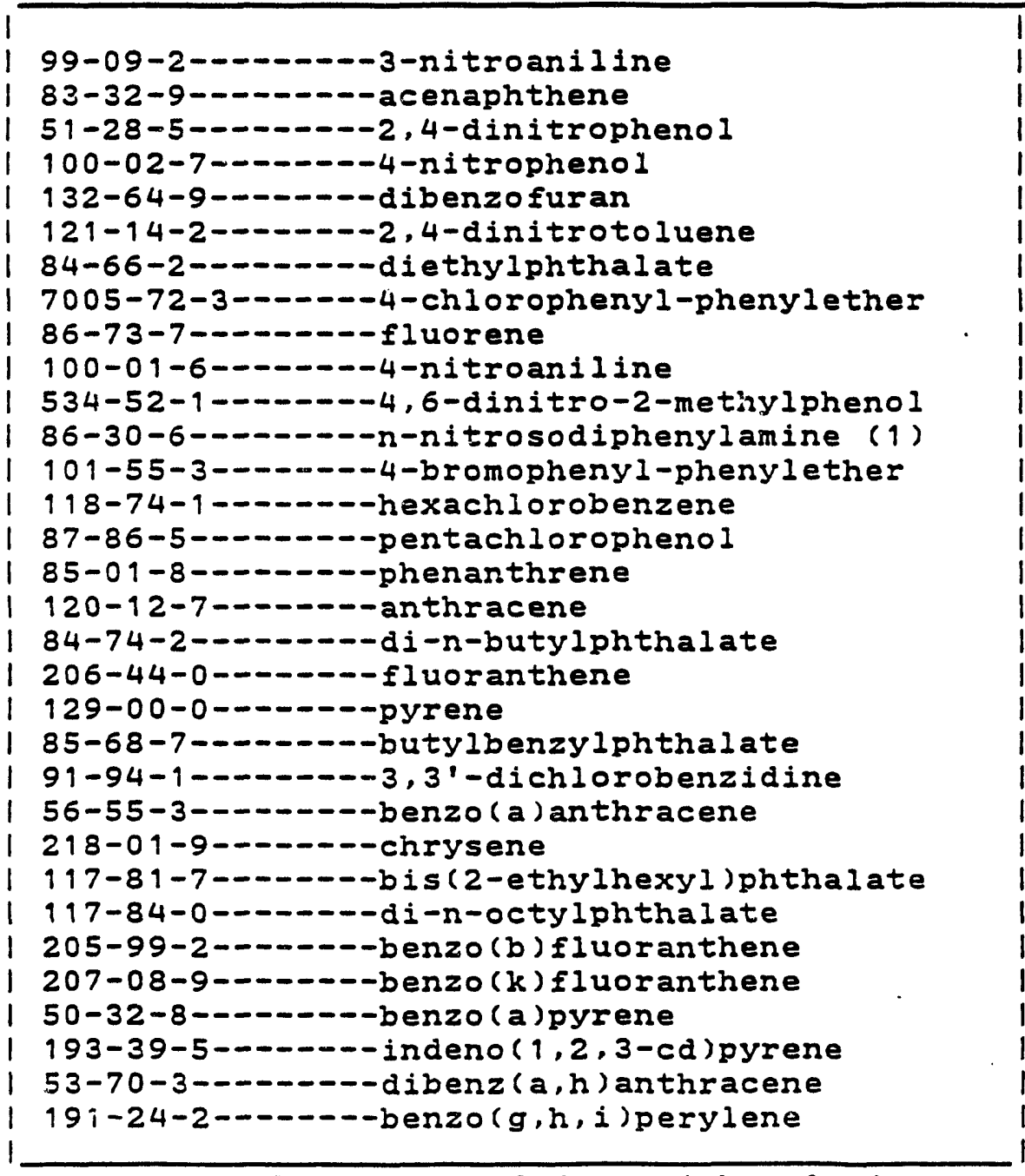

(1) - Cannot be separated from Diphenylamine
160.

31.

160.

160 .

31.

31.

31.

31.

31.

160.

70 .

31.

31.

31.

160.

31.

39.

31.

39.

31.

31.

63.

31.

31.

31.

31.

31.

31.

31.

31 .

31 .

31. 


\section{Semivolatile organic Analysis Data}

zequest Number: OAL 94146

ieries: Frequency: ON REQUEST

justomer Name: SIEGRIST

Lab Sample ID: 910228-063

sample wt/vol: $\quad 32.0 \mathrm{G}$

Jate Sampled: 20-Feb-1991 12:20

: Moisture: not dec. dec:

laterial Description SOIL

iumber TICs found: 20

Matrix: SOIL \& WATER

Lab File ID: $>C 3560$

Date Received 27-Feb-1991 14:30

Date Analyzed: 19-Mar-1991

Date of Report: 2-MAY-91

CONCENTRATION UNITS:
EPA SAMPLE NO.

TPO4-65

(UG/L OY UG/KG) UG/KG

\begin{tabular}{|c|c|}
\hline CAS NO. & I COMPOUND NAME \\
\hline 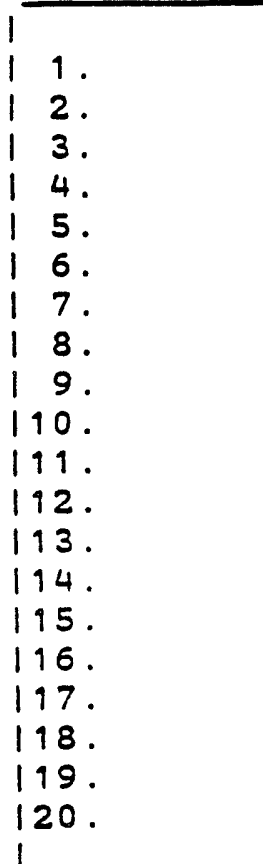 & 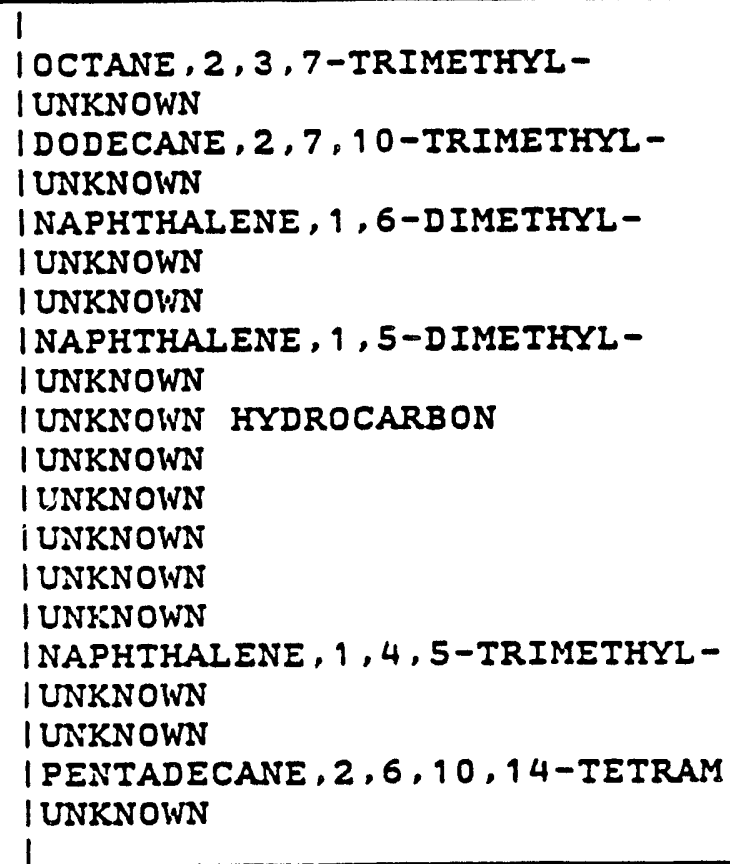 \\
\hline
\end{tabular}

Reviewed by:

\begin{tabular}{|c|c|c|c|c|c|}
\hline 1 & RT & 1 & CONC & & $Q$ \\
\hline I & & 1 & & 1 & \\
\hline I & 19.12 & 1 & 36. & 1 & $\mathrm{~J}$ \\
\hline 1 & 20.50 & 1 & 18. & 1 & $\mathrm{~J}$ \\
\hline 1 & 21.03 & 1 & 75 . & 1 & $\mathbf{J}$ \\
\hline 1 & 21.94 & ! & 52. & 1 & $\mathrm{~J}$ \\
\hline 1 & 21.81 & 1 & 25. & 1 & J \\
\hline 1 & 22.05 & 1 & 60. & 1 & $\mathbf{J}$ \\
\hline 1 & 22.10 & 1 & 53. & 1 & $\mathrm{~J}$ \\
\hline 1 & 22.15 & I & 21. & 1 & J \\
\hline 1 & 22.40 & 1 & 18. & 1 & $J$ \\
\hline 1 & 22.50 & I & 120. & 1 & $J$ \\
\hline 1 & 22.57 & I & 24. & 1 & $\mathrm{~J}$ \\
\hline 1 & 22.74 & 1 & 58. & 1 & $J$ \\
\hline 1 & 22.82 & 1 & 17. & 1 & $\mathrm{~J}$ \\
\hline 1 & 23.35 & 1 & 21. & 1 & $\mathrm{~J}$ \\
\hline 1 & 23.60 & 1 & 22. & 1 & $\mathrm{~J}$ \\
\hline 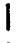 & 23.95 & 1 & 25. & 1 & $\mathrm{~J}$ \\
\hline 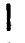 & 24.49 & 1 & 27. & 1 & $J$ \\
\hline & 25.47 & 1 & 94. & 1 & $J$ \\
\hline 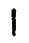 & 26.34 & 1 & 180. & 1 & $\mathrm{~J}$ \\
\hline & 28.94 & 1 & 14. & & $\mathrm{~J}$ \\
\hline
\end{tabular}

Date : 
Lab Name: Oak Ridge National Lab Contract: NR

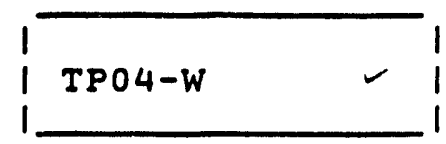

Lab Code: Case no: ORNL SAS NO: NR SDG NO: G228

Matrix: (soil/water) WATER

Sample wt/vol:

$1 \mathrm{ML}$

Level: (low/med) Low

\% Moisture: not dec.

Colums: (pack/cap) PACK
Lab Sample ID: 910228-064

Lab File ID: >G2114

Date Received 28-Feb-1991

Date Analyzed: 28-Feb-1991

Dilution Factor: $\quad 5.0$

CAS NO.

COMPOUND

CONCENTRATION UNITS: (UG/L Or UG/KG) UG/L

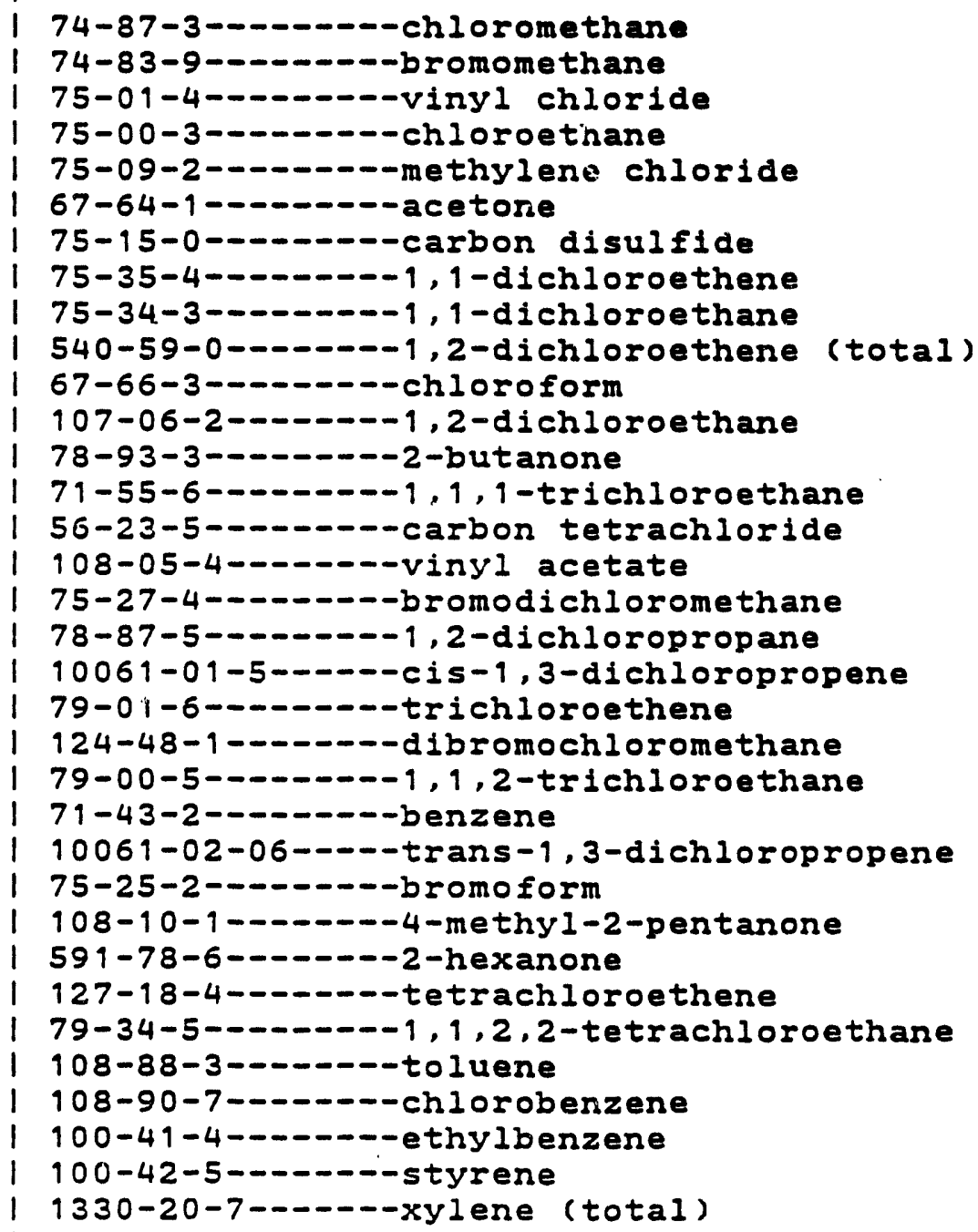

Reviewed by:

50.

50 .

50 .

50 .

5.00

580 .

25 .

25 .

25 .

25 .

25.

25.

50.

25.

25.

50 .

25.

25.

25.

25.

25.

25.

25.

25.

25.

50 .

50.

25.

25.

25.

25.

25.

25.

25.

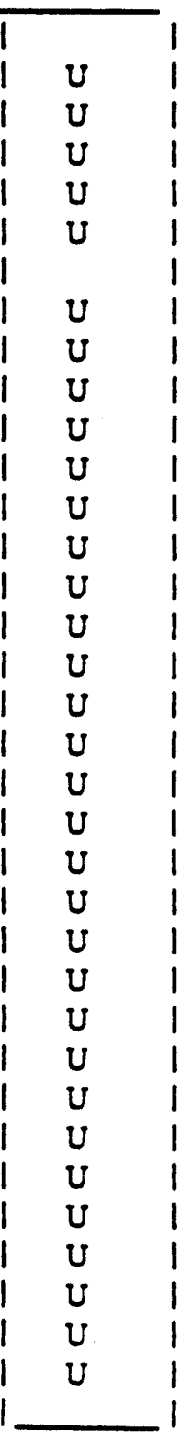

Date: 


\section{VOLATILE ORGANICS ANALYSIS DATA SHEET}

Request Number: OAL94146

Procedure Number: 8240

Matrix: SOIL \& WATER

series:

Frequency: ON REQUEST

Customer Name: SIEGRIST

$1 \mathrm{ML}$

sample wt/vol:

Date Sampled: 20-Feb-1991 11:40

\% Moisture: not dec.

dec:

Material Description WATER

Number TICs found, 1
EPA SAMPLE NO.

$$
\text { TP04-W }
$$

Lab Sample ID: 910228-064

Lab File ID: $\quad>62114$

Date Received 27-Feb-1991 14:30

Date Annlyzed, 28-Feb-1991

Date of Report: 2-MAY-91

CONCENTRATION UNITS: (UG/L OI UG/KG) UG/L

\begin{tabular}{|l|l|l|l|l|l|}
\hline CAS NO. I COMPOUND NAME & RI & CONC & Q I \\
\hline 1. & I IUNKNOWN & 9.72 & 39. & $\mathrm{~J}$ \\
\hline
\end{tabular}


Semivolatile Organic Analysis Data

EPA SAMPLE NO.

Lab Name: Oak Ridge National Lab Contract: NR

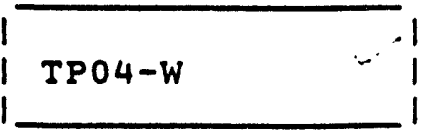

Lab Code: Case no: CLP

SAS NO: NR

SDG NO: $\mathrm{C} 425$

Matrix: (soil/water) WATER

Sample wt/vol: $160 \mathrm{ML}$

Level: (low/med) Low

\% Moisture: not dec. dec.

Extraction: (Sepf/Cont/Sonc) SEPF

GPC Cleanup: $(Y / N) N$

$\mathrm{pH}: \quad 8.08$
Lab Sample ID: 910228-064

Lab File ID: $\quad>C 3767$

Date Received 28-Feb-1991

Date Analyzed: 25-Apr-1991

Date Extracted: 18-Mar-1991

Dilution Factor: $\quad 6.3$

CAS NO.

COMPOUND

CONCENTRATION UNITS:

(UG/L or UG/KG) UG/I

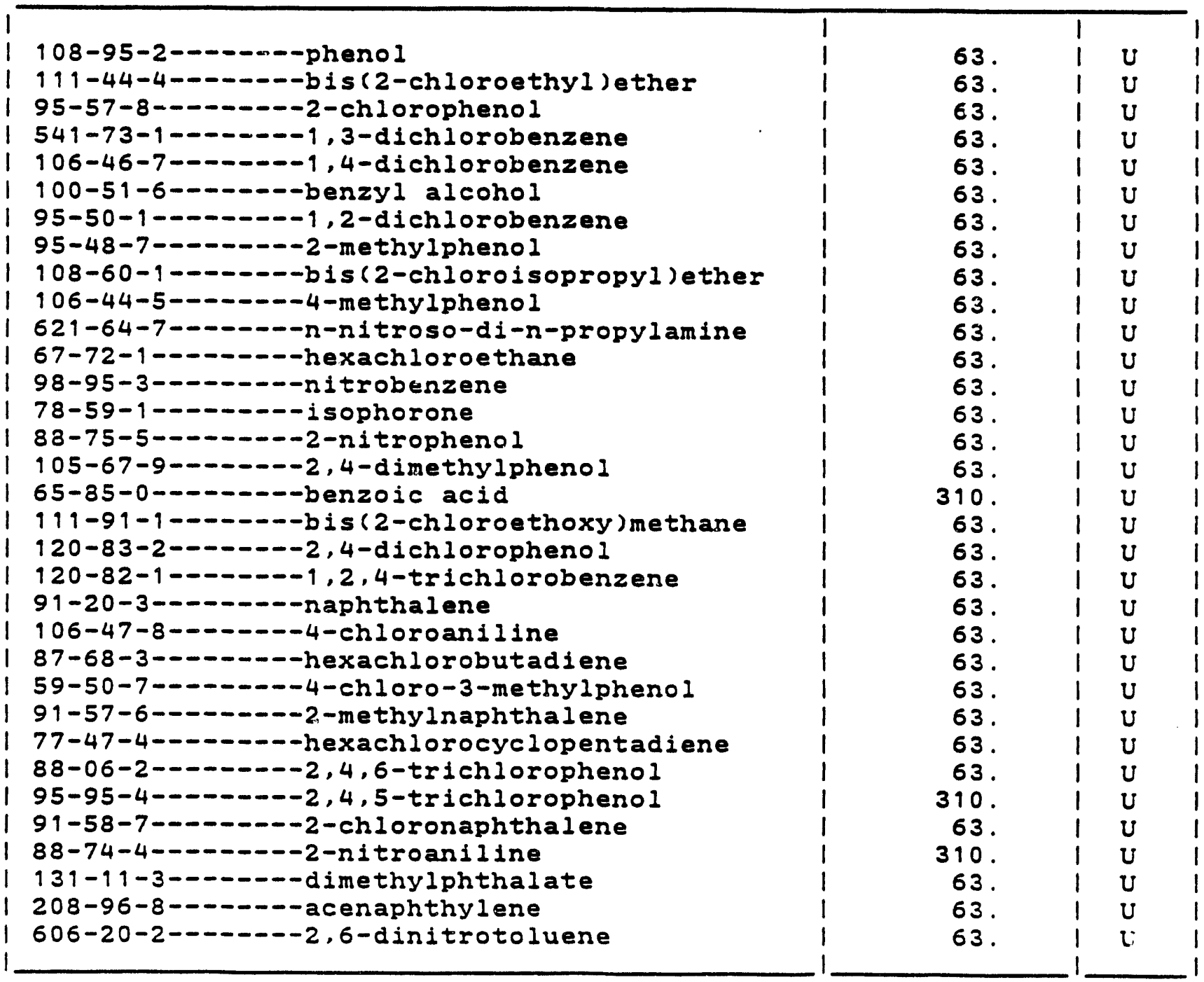


Semivolatile Organic Analysis Data

EPA SAMPLE NO.

Lab Name: Oak Ridge National Lab Contract: NR

TP04-W

Lab Code: Case no: CLP SAS No: NR SDG NO: C425

Matrix: (soil/water) WATER

Lab Sample ID: 910228-064

Sample wt/vol: $\quad 160 \mathrm{ML}$

Lab File ID: >C3767

Level: (low/med) LoW

Date Received 28-Feb-1991

\% Moisture: not dec. dec.

Date Aralyzed, 25-Apr-1991

Extraction: (Sepf/Cont/Sonc) SEPF

Date Extracted: 18-Mar-1991

GPC Cleanup: $(Y / N) N \quad$ pH: 8.08

Dilution Factor: $\quad 6.3$

CAS No.

COMPOUND

CONCENTRATION UNITS:

(UG/L OY UG/KG) UG/L Q

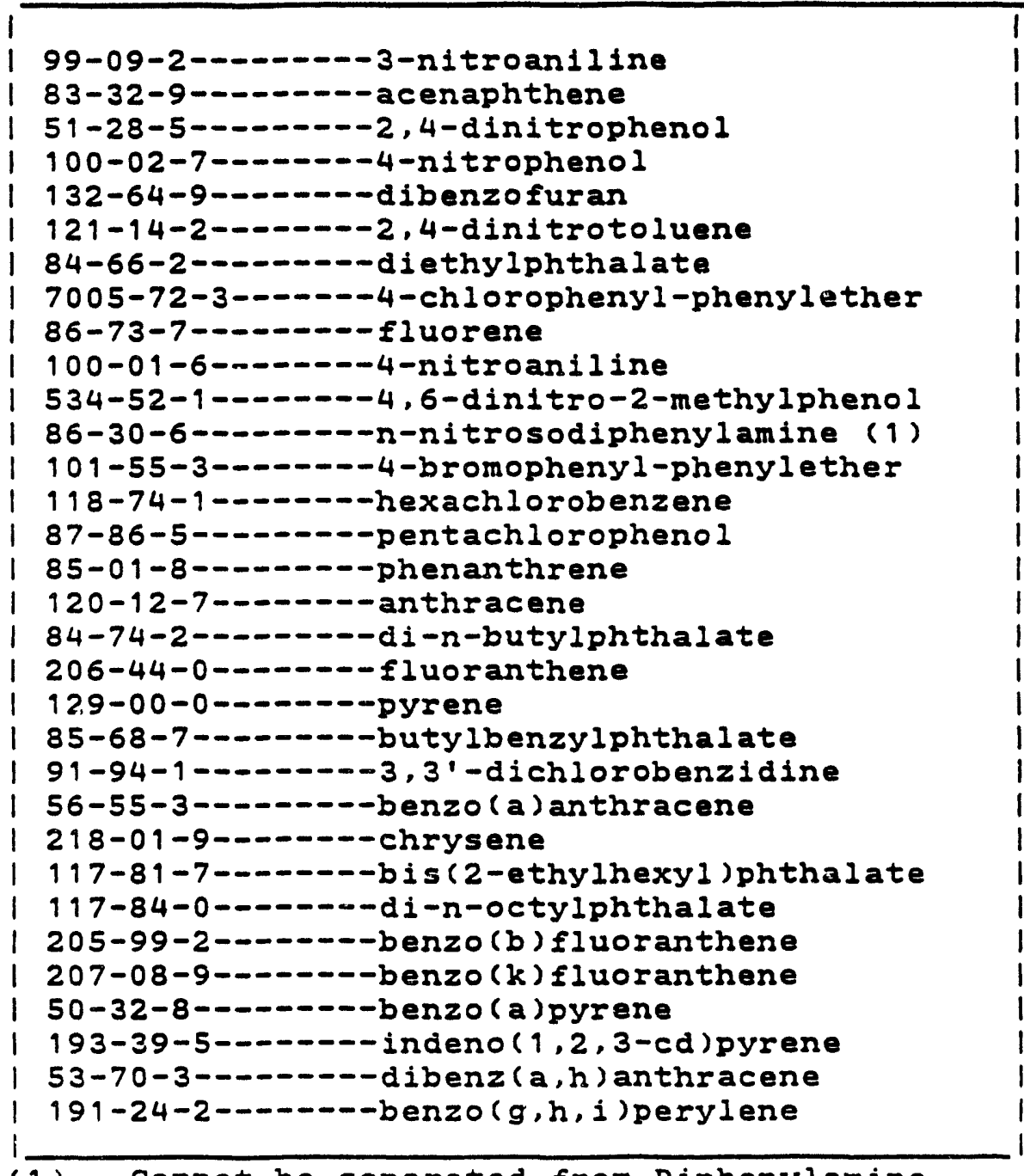

(1) - Cannot be separated from Diphenylamine

Reviewed by:

Date:

310.

63.

310.

310 .

63.

63.

63.

63.

63.

310 .

310.

63.

63.

63.

310.

63.

63.

63.

63.

63.

130 .

130.

63.

63.

150.

63.

63.

63.

63.

63.

63.

63. 
Semivolatile Organic Analysis Data

EPA SAMPLE NO.

Request Number: OAL94\$46

Procedure Number: $\quad \$ 240$

Matrix: SOIL \& WATER

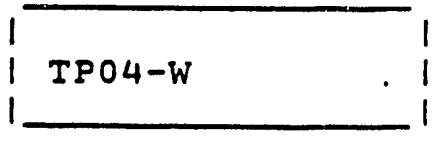

Series:

Frequency: ON REQUEST

Charge Number:

$3 \approx 357130$

Customer Name: SIEGRIST

Lab Sample ID: 910228-064

Sample wt/vol: $160 \mathrm{ML}$

Lab File ID: $\quad>C 3767$

Date Sampled: 20-Feb-1991 11:40

Date Received 27-Feb-1991 $14: 30$

\% Moisture: not dec. dec:

Date Aralyzed: 25-Apr-1991

Material Description WATER

Date of Report: 2-MAY-91

Number TICs found: 20

CONCENTRATION UNITS: (UG/L OF UG/KG) UG/L

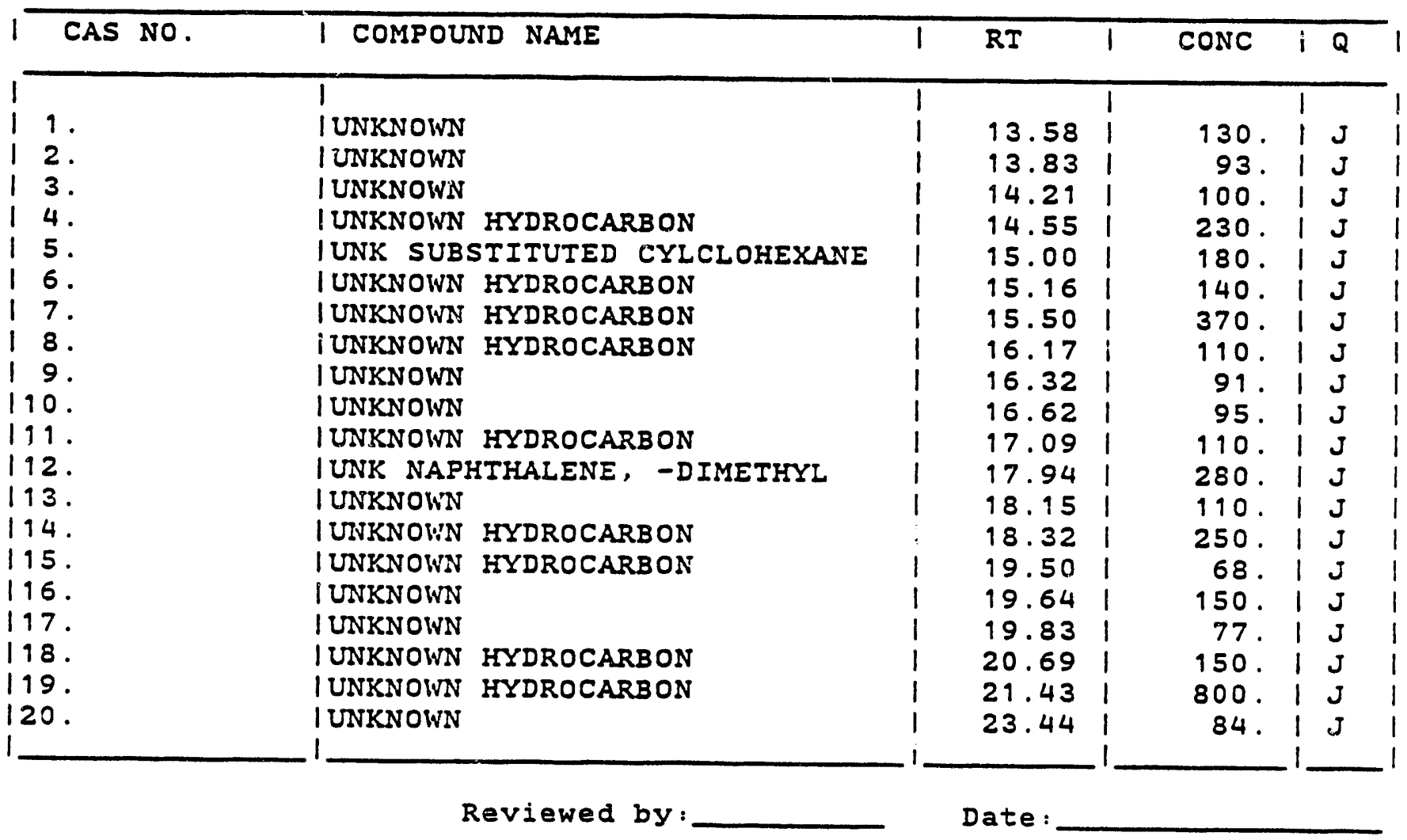


Lab Name: Oak Ridge National Lab

Lab code:

Case no: ORNL

Matrix: (soil/water) soIL

Sample wt/vol:

$5 \mathbf{G}$

Level: (low/med) LoW

\% Moisture: not dec.

Column: (pack/cap) CAP
Contract: NR

SAS NO: NR

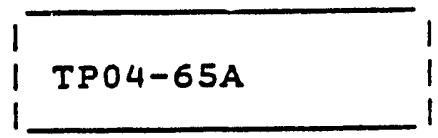

SDG NO: 0308
Lab Sample ID: 910228-065

Lab File ID: $\quad>01200$

Date Received 28-Feb-1991

Date Analyzed: 8-Mar-1991

Dilution Factor: $\quad 1.0$

CAS NO.

COMPOUND

CONCENTRATION UNITS:

(UG/L OI UG/KG) UG/KG

74-87-3--.----chloromethane

1 74-83-9-------bromomethane

1 75-01-4--------vinyl chloride

1 75-00-3--.---.-chloroethane

| 75-09-2-..----methylene chloride

| 67-64-1--------acetone

1 75-15-0-------carbon disulfide

1 75-35-4--.----1,1-dichloroethene

1 75-34-3-------1, 1-dichloroethane

(540-59-0--.---1,2-dichloroethene (total)

| 67-66-3-.------chloroform

1 107-06-2-------1,2-dichloroethane

| 78-93-3---------2-butanone

| 71-55-6-------1,9,1-trichloroethane

I 56-23-5--------carbon tetrachloride

1 108-05-4--------vinyl acetate

1 75-27-4-------bromodichloromethane

1 78-87-5--------1,2-dichloropropane

1 10061-01-5-----cis-1,3-dichloropropene

1 79-01-6--..--.-trichloroethene

1 124-48-1------dibromochloromethane

79-00-5------ - 1, 1,2-trichloroethane

$71-43-2-------$ benzene

1 90061-02-06-----trans-1,3-dichloropropene

I 75-25-2--------bromoform

1 108-10-1------4-methyl-2-pentanone

591-78-6-------2-hexanone

127-18-4-------tetrachloroethene

79-34-5--.--- -9, 1,2,2-tetrachloroethane

108-88-3-------toluene

108-90-7-------chlorobenzene

100-41-4-------ethylbenzene

100-42-5-------styrene

1330-20-7------xylene (total)
10 .

10 .

10 .

10 .

5.00

270.

5.00

5.00

5.00

5.00

5.00

5.00

10 .

5.00

5.00

10 .

5.00

5.00

5.00

5.00

5.00

5.00

5.00

5.00

5.00

10 .

10 .

5.00

5.00

5.00

5.00

5.00

5.00

5.00 
Lab Name: Oak Ridge National Lab

Lab Code :

Case nO: ORNL

Matrix: (soil/water) soIL

Sample wt/vol: $\quad 0.8 \mathrm{G}$

Level: (low/med) Low

\% Moisture: not dec.

Column: (pack/cap) CAP contract: NR

SAS NO: NR
1

I TPO4-65B

SDG NO: 0308

Lab Sample ID: 910228-066

Lab File ID: $\quad>01210$

Date Received 28-Feb-1991

Date Aralyzed: 9-Mar-1991

Dilution Factor: $\quad 50$

CONCENTRATION UNITS

CAS NO.

COMPOUND

(UG/L or UG/KG) UG/KG

Q

74-87-3-- - - chloromethane

1 74-83-9---n---bromomethane

| 75-01-4--------vinyl chloride

1 75-00-3-------chloroethane

| 75-09-2-------methylene chloride

I 67-64-1-------acetone

I 75-15-0-------carbon disulfide

1. 75-35-4--------1,1-dichloroethene

II: $75-34-3-------1,1-d i c h l o r o e t h a n e$

| 540-59-0------1,2-dichloroethene (total)

I 67-66-3--n---chloroform

1 107-06-2------1,2-dichloroethare

| 78-93-3--------2-butanone

1 71-55-6---n---1, 1, 1-trichloroethane

1 56-23-5--.----carbon tetrachloride

I 108-05-4-------vinyl acetate

| 75-27-4--n----bromodichloromethane

1 78-87-5------ - 1,2-dichloropropane

1 10061-01-5-----cis-1,3-dichloropropene

1 79-01-6---n---trichloroethene

1 124-48-1-------dibromochloromethane

1 79-00-5--.---- 1, 1,2-trichloroethane

1 71-43-2-------benzene

1 10061-02-06----trans-1,3-dichloropropene

| 75-25-2-------bromoform

l 108-10-1-------4-methyl-2-pentanone

| 591-78-6-------2-hexanone

| 127-18-4-------tetrachloroethene

| 79-34-5-n-- -- 1, 1,2,2-tetrachloroethane

1 108-88-3--n---noluene

I 108-90-7-------chlorobenzene

I 100-41-4-------ethylbenzene

I 100-42-5-------styrene

I 1330-20-7-----xylene (total)

\begin{tabular}{|c|c|c|c|c|}
\hline & 1 & & 1 & \\
\hline & 1 & 500. & 1 & $U$ \\
\hline & 1 & 500. & 1 & $U$ \\
\hline & 1 & 500. & 1 & $U$ \\
\hline & i & 500. & i & U \\
\hline & i & 250 . & 1 & U \\
\hline & 1 & 5400. & 1 & \\
\hline & 1 & 250. & 1 & $U$ \\
\hline & 1 & 250. & 1 & $U$ \\
\hline & 1 & 250. & 1 & $U$ \\
\hline totall & 1 & 250 . & 1 & $U$ \\
\hline & 1 & 250. & 1 & $U$ \\
\hline & 1 & 250 . & 1 & U \\
\hline & $i$ & 240 . & 1 & $\mathrm{~J}$ \\
\hline ie & 1 & 250 . & 1 & $U$ \\
\hline & 1 & 250 . & 1 & $U$ \\
\hline & 1 & 500. & 1 & $U$ \\
\hline & 1 & 250. & 1 & $U$ \\
\hline & 1 & 250. & 1 & $U$ \\
\hline ene & 1 & 250 . & 1 & $U$ \\
\hline & 1 & 250 . & 1 & $U$ \\
\hline & 1 & 250. & 1 & $U$ \\
\hline & 1 & 250 . & 1 & $U$ \\
\hline & 1 & 250 . & 1 & $U$ \\
\hline opene & 1 & 250. & 1 & $U$ \\
\hline & 1 & 250. & 1 & $U$ \\
\hline & 1 & 500. & 1 & $\mathrm{U}$ \\
\hline & i & 500. & $i$ & $U$ \\
\hline & 1 & 250 . & 1 & $U$ \\
\hline thane & 1 & 250 . & 1 & $U$ \\
\hline & 1 & 250. & 1 & $U$ \\
\hline & 1 & 250. & 1 & $U$ \\
\hline & 1 & 250. & 1 & $U$ \\
\hline & 1 & 250 . & 1 & $U$ \\
\hline & 1 & 250 . & 1 & $U$ \\
\hline
\end{tabular}

Reviewed by:

Date : 


\section{VOLATILE ORGANICS ANALYSIS DATA SHEET}

EPA SAMPLE NO.

Lab Name: Oak Ridge National Lab

Lab Code:

Case no:

Matrix: (soil/water) WATER

Sample wt/vol:

ML

Level: ( low/med)

\% Moisture: not dec.

Column: (pack/cap) contract :

SAS NO:

SDG NO:

Lab Sample ID: 910228-067

Lab File ID:

Date Received 28-Feb-1991

Date Analyzed: 30-Apr-1991

Dilution Factor: $\quad 1.0$

CONCENTRATION UNITS:

CAS NO. COMPOUND (UG/L OI UG/KG) UG/L

Q

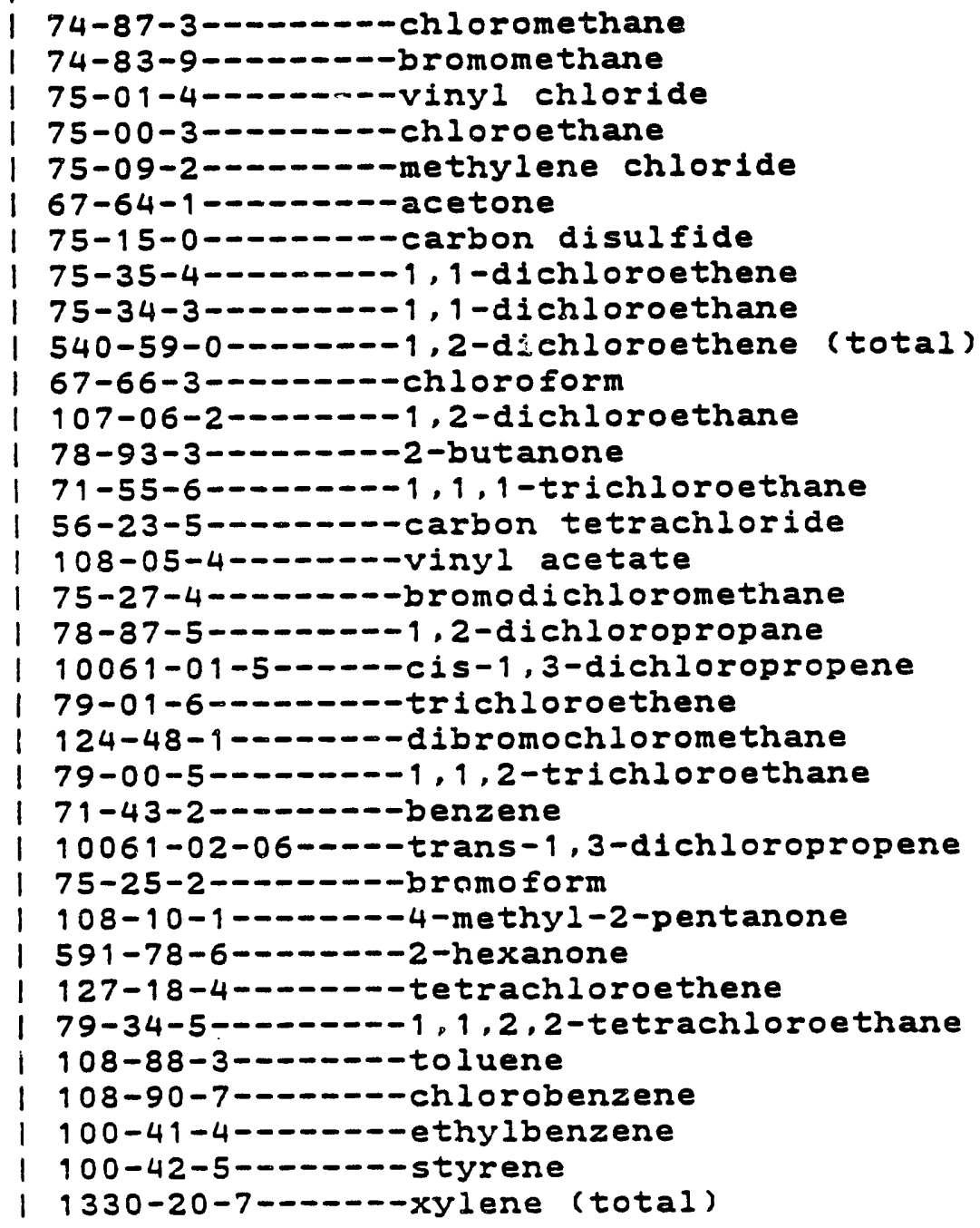

$* * * * * \pi * *$ $* * * * * * * *$ ********* $\boldsymbol{*} * \boldsymbol{*} * \boldsymbol{*} \boldsymbol{*} \boldsymbol{*} \boldsymbol{*}$ $* * * * * * * *$ $* \pi * * * * * *$ $* * * * * * * *$ $\boldsymbol{*} * \boldsymbol{*} * \boldsymbol{*} * \boldsymbol{*} * \boldsymbol{*}$ $\boldsymbol{*} * \boldsymbol{*} * \boldsymbol{*} * \boldsymbol{*} * \boldsymbol{*}$ $* * * * * * * *$ * $* * * * * * * *$ $\boldsymbol{*} * \boldsymbol{*} * \boldsymbol{*} * \boldsymbol{*} * \boldsymbol{*}$ $* * * * * * * * *$ $* * * * * * * *$ $* * * * * * * *$ $* * * * * * * *$ ******** $\boldsymbol{*} * \boldsymbol{*} * \boldsymbol{*} * \boldsymbol{*} *$ $\boldsymbol{*} * \boldsymbol{*} * \boldsymbol{*} * \boldsymbol{*} * \boldsymbol{*}$ $* \pi * * * * * *$ $* * * * * * * *$ $\boldsymbol{*} * \boldsymbol{*} * \boldsymbol{*} * \boldsymbol{*} * \boldsymbol{*}$ $\boldsymbol{*} * \boldsymbol{*} \boldsymbol{*} \boldsymbol{*} \boldsymbol{*} \boldsymbol{*} \boldsymbol{*}$ $* * * * * * * *$ $* * * * * * * *$ $* * * * * * * *$ $* * * * * * * *$ $* * * * * * * *$ $* * * * * * * *$ $* * * * * * * * *$ ********** $\boldsymbol{*} * \boldsymbol{*} * \boldsymbol{*} * \boldsymbol{*} *$ $* * * * * * * *$ $* * * * * * * *$ Date : 
Lab Name: Oak Ridge National Lab

Lab Code:

Case no: ORNL

Matrix: (soil/water) soIl

Sample wt/vol: $\quad 0.8 \mathrm{G}$

Level: (low/med) LoW

\% Moisture: not dec.

Column: (pack/cap) CAP
Contract: NR

SAS NO: NR

\section{TPO3-12B}

SDG NO: 0308

Lab Sample ID: 910228-068

Lab File ID: >01211

Date Received 28-Feb-1991

Date Aralyzed: 9-Mar-1991

Dilution Factor:

50

CAS NO. COMPOUND

CONCENTRATION UNITS: (UG/L or UG/KG) UG/KG

Q

\begin{tabular}{|c|}
\hline 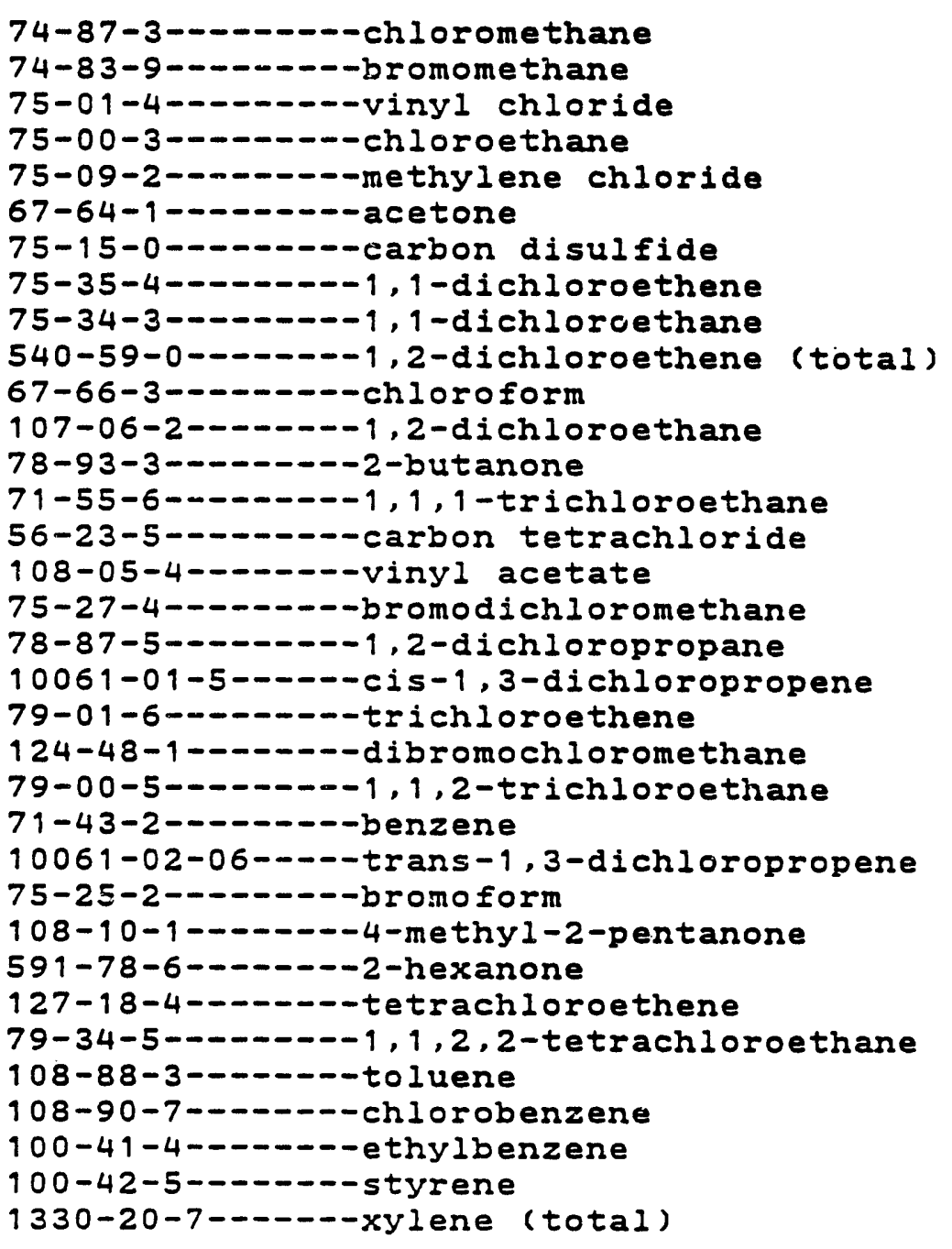 \\
\hline
\end{tabular}

Reviewed by:

500 .

500 .

500 .

500 .

250 .

500 .

250.

250 .

250.

250 .

250.

250 .

500 .

70 .

250 .

500 .

250 .

250.

250 .

250 .

250 .

250 .

250 .

250 .

250 .

500

500 .

250 .

250 .

250 .

83.

250 .

250.

250 . 
Lab Name: Oak Ridge National Lab

Lab Code:

Case no:

Matrix: (soil/water) WATER

Sample wt/vol:

ML

\section{Level: (low/med)}

\% Moisture: not dec.

Column: (pack/cap)
Contract:

SAS NO:

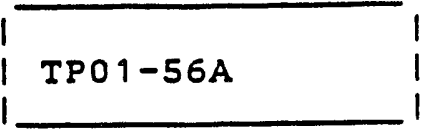

SDG NO:

Lab Sample ID: 910228-069

Lab File ID:

Date Received 28-Feb-1991

Date Analyzed: 30-Apr-1991

Dilution Factor: $\quad 1.0$

CONCENTRATION UNITS:

CAS NO.

COMPOUND

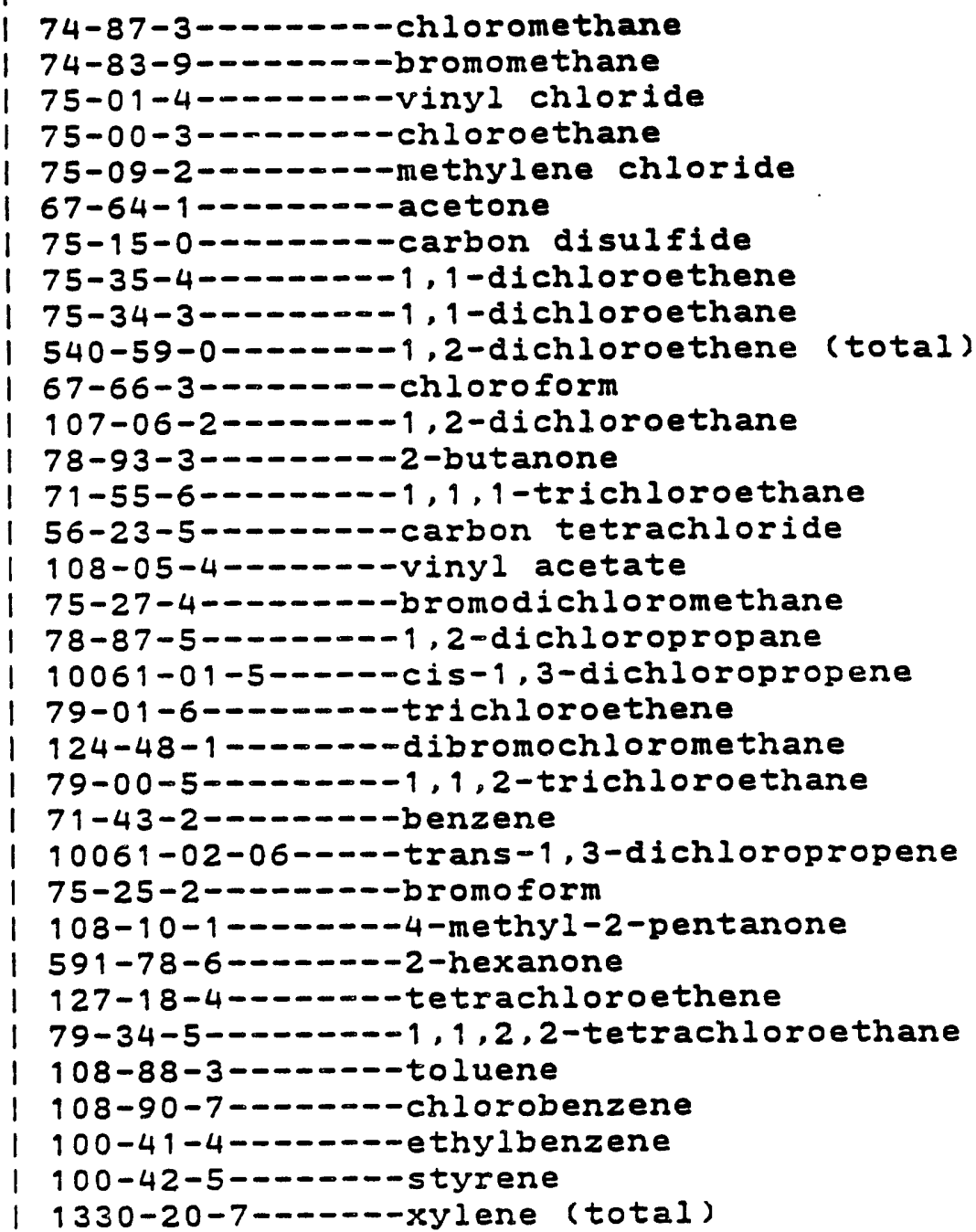

$\boldsymbol{*} * \boldsymbol{*} * \boldsymbol{*} * \boldsymbol{*} * \boldsymbol{*}$ $* * * * * * * *$ $\boldsymbol{*} * \boldsymbol{*} * \boldsymbol{*} * \boldsymbol{*} * \boldsymbol{*}$ $* * * * * * * *$ $* * * * * * * *$ $* \pi * * * \pi * *$ $* * * * * * * *$ $* * * * * * * *$ $* * * * * * * *$ $* * * * * * * *$ $* * * * * * * *$ $* * * * * * * *$ $* * * * * * * *$ $* * * * * * * *$ ********* $* * * * * * * *$ $* * * * * * * *$ $* * * * * * * *$ $* * * * * * * *$ $* * * * * * * *$ $* * * * * * * *$ $* * * * * * * *$ $* * * * * * * *$ $\boldsymbol{*} * \boldsymbol{*} * \boldsymbol{*} * \boldsymbol{*} * \boldsymbol{*}$ $* * * * * * * *$ $\boldsymbol{*} * \boldsymbol{*} \boldsymbol{*} \boldsymbol{*} \boldsymbol{*} \boldsymbol{*} \boldsymbol{*}$ ******** $* * * * * * * *$ $* * * * * * * *$ $* * * * * * * *$ $* * * * * * * *$ $\boldsymbol{*} * \boldsymbol{*} * \boldsymbol{*} * \boldsymbol{*} *$ $* * * * * * * *$ $* * * * * * * *$ 


\section{VOLATILE ORGANICS ANALYSIS DATA SHEET}

EPA SAMPLE NO.

Lab Name: Oak Ridge National Lab

Lab Code :

Case no: ORNL

Matrix: (soil/water) soIL

Sample wt/vol: $0.8 \mathrm{G}$

Level: ( low/med) Low

\% Moisture: not dec.

Colums: (pack/cap) CAP
Contract: NR

SAS NO: NR

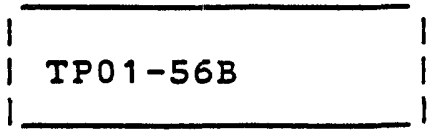

SDG NO: 0308

Lab Sample ID: $910228-070$

Lab File ID: $\quad>01212$

Date Received 28-Feb-1991

Date Analyzed: 9-Mar-1991

Dilution Factor: $\quad 50$

CONCENTRATION UNITS :

CAS NO. COMPOUND (UG/L OY UG/KG) UG/KG

Q

500

500 .

500

500

250 .

500

250 .

250

250 .

250 .

250 .

250

500 .

250 .

250 .

500 .

250 .

250 .

250 .

250 .

250 .

250 .

250 .

250 .

250 .

500 .

500 .

250 .

250 .

250 .

250 .

250 .

250 .

250 . 
Lab Name: Oak Ridge National Lab Lab Code:

Case no:

Matrix: (soil/water) WATER

Sample wt/vol:

ML

Level: (low/med)

\% Moisture: not dec.

Column: (pack/cap) contract :

SAS NO: NR
FUEL

SDG NO:

Lab Sample ID: 910228-071

Lab File ID:

Date Received 28-Feb-1991

Date Analyzed: 11-Mar-1991

Dilution Factor:

CONCENTRATION UNITS:

CAS NO.

COMPOUND

(UG/L OF UG/KG) UG/L

Q

74-87-3-------chloromethane

74-83-9-------bromomethane

75-01-4---n---vinyl chloride

1 75-00-3--.-.--chloroethane

I 75-09-2-------methylene chloride

I 67-64-1--------acetone

1 75-15-0--n----carbon disulfide

I 75-35-4------- 1,1-dichloroethene

I 75-34-3-n-----1, 1-dichloroethane

| 540-59-0--.--- 1,2-dichloroethene (total)

| 67-66-3-n-.--n-chloroform

1 107-06-2-- - - - 1,2-dichloroethane

1 78-93-3-------2-butanone

| 71-55-6--------1,1,1-trichloroethane

1 56-23-5-------carbon tetrachloride

| 108-05-4------vinyl acetate

1 75-27-4----n--bromodichloromethane

| 73-87-5--------1,2-dichloropropane

1 10061-01-5-----cis-1,3-dichloropropene

| 79-01-6-------trichloroethene

| 124-48-1-------dibromochloromethane

1 79-00-5------- 1, 1,2-trichloroethane

I 71-43-2--------benzene

1 10061-02-06----trans-1,3-dichloropropene

1 75-25-2-- - - - bromoform

1 108-10-1-------4-methyl-2-pentanone

I 591-78-6-------2-hexanone

I 127-18-4-------tetrachloroethene

1 79-34-5-- - - - 1, 1,2,2-tetrachloroethane

1 108-88-3-------toluene

1 108-90-7-------chlorobenzene

1 100-41-4-------ethylbenzene

| 100-42-5-------styrene

I 1330-20-7--.--xylene (total)
*********

$* * * * * * * * \pi$

********

$* * * * * * * * *$

$* * * * * * * *$

********

$* * * * * * * *$

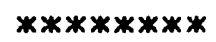

$* * * * * * * *$

$\boldsymbol{*} * \boldsymbol{*} * \boldsymbol{*} * \boldsymbol{*} *$

$* * * * * * * *$

$* * * * * * * *$

$* * * * * * * *$

$* * * * * * * *$

$* * * * * * * *$

*********

$* * * * * * * *$

$* * * * * * * *$

*********

$* * * * * * * *$

$* * * * * * * *$

********

$* * * * * * * *$

*********

$* * * * * * * *$

$* * * * * * * *$

*********

$* * * * * * * *$

$* * * * * * * *$

$* * * * * * * *$

$* * * * * * * *$

$* * * * * * * *$

$* \pi * * * * * *$

$* * * * * * * *$ 
Semivolatile organic Analysis Data

EPA SAMPLE NO.

Lab Name: Oak Ridge National Lab Contract: NR

FUEL

Lab code: Case no: WASTE

SAS NO: NR

SDG NO: $C 319$

Matrix: (soil/water) soIL

Lab Sample ID: 910228-071

Sample wt/vol: $\quad .1$ G

Lab File ID: $>C 3566$

Level: (low/med) MED

Date Received 28-Feb-1991

\% Moisture: not dec. dec.

Date Analyzed: 20-Mar-1991

Extraction: (Sepf/cont/Sonc) DIL

Date Extracted: 11-Mar-1991

GPC Cleanup: $(Y / N) N$

pH : NR

Dilution Factor:

100.

CAS No.

COMPOUND

CONCENTRATION UNITS:

(UG/L OI UG/KG) UG/L

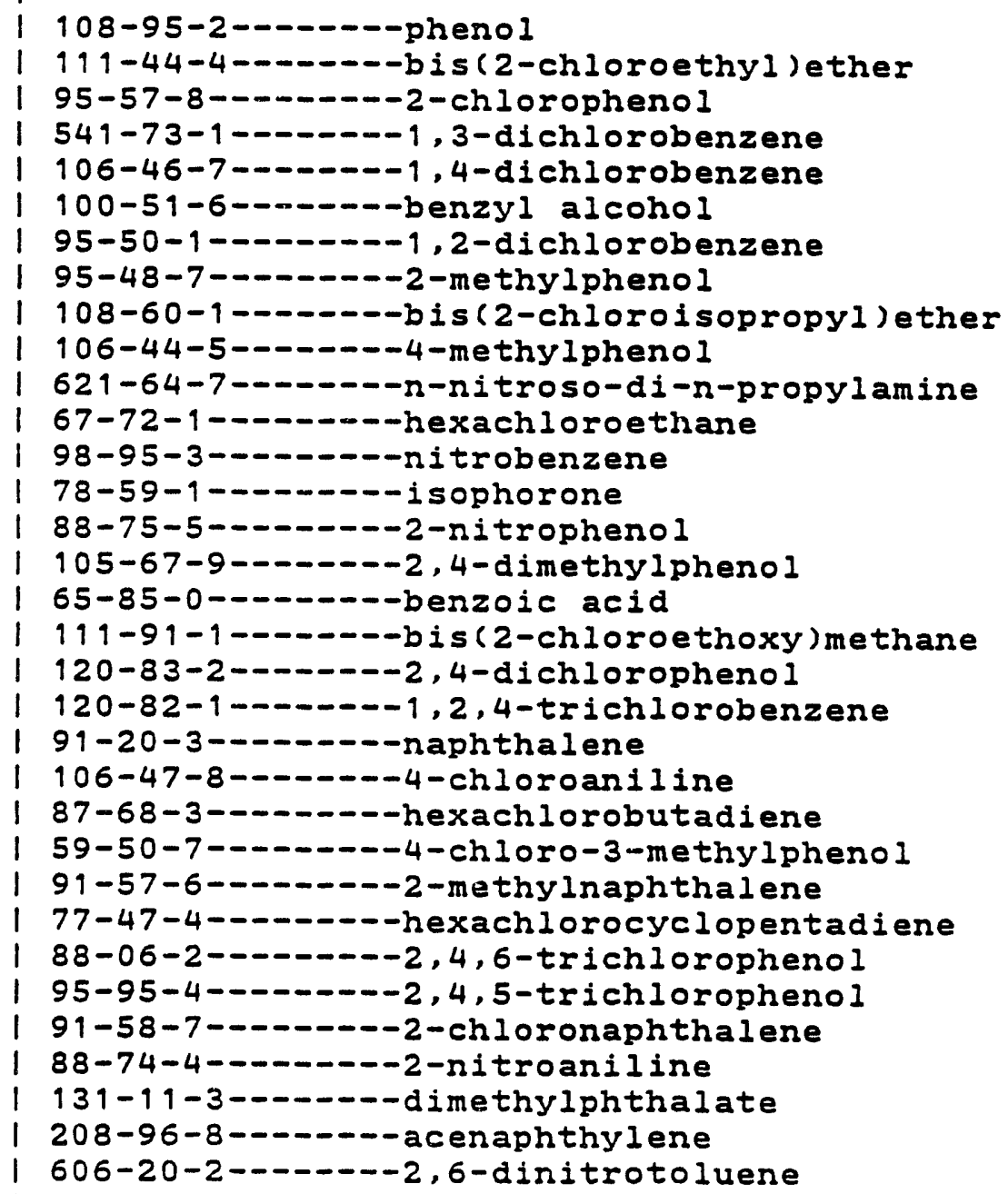


Lab Name: Oak Ridge National Lab Contract: NR

FUEL

Lab code: Case no: WASTE SAS NO: NR SDG No: C319

Matrix: (soil/water) soIl

Sample wt/vol: $\quad .1 \mathrm{G}$

Level: ( low/med) MED

\% Moisture: not dec. dec.

Extraction: (Sepf/cont/Sonc) DIL

GPC Cleasup: $(Y / N) N$

pH : $\quad$ NR
Lab Sample ID: 910228-071

Lab File ID: $\quad>C 3566$

Date Received 28-Feb-1991

Date Analyzed: 20-Mar-1991

Date Extracted: 11-Mar-1991

Dilution Factor: 100.

CAS NO.

COMPOUND

CONCENTRATION UNITS: (UG/L or UG/KG) UG/L

\begin{tabular}{|c|}
\hline 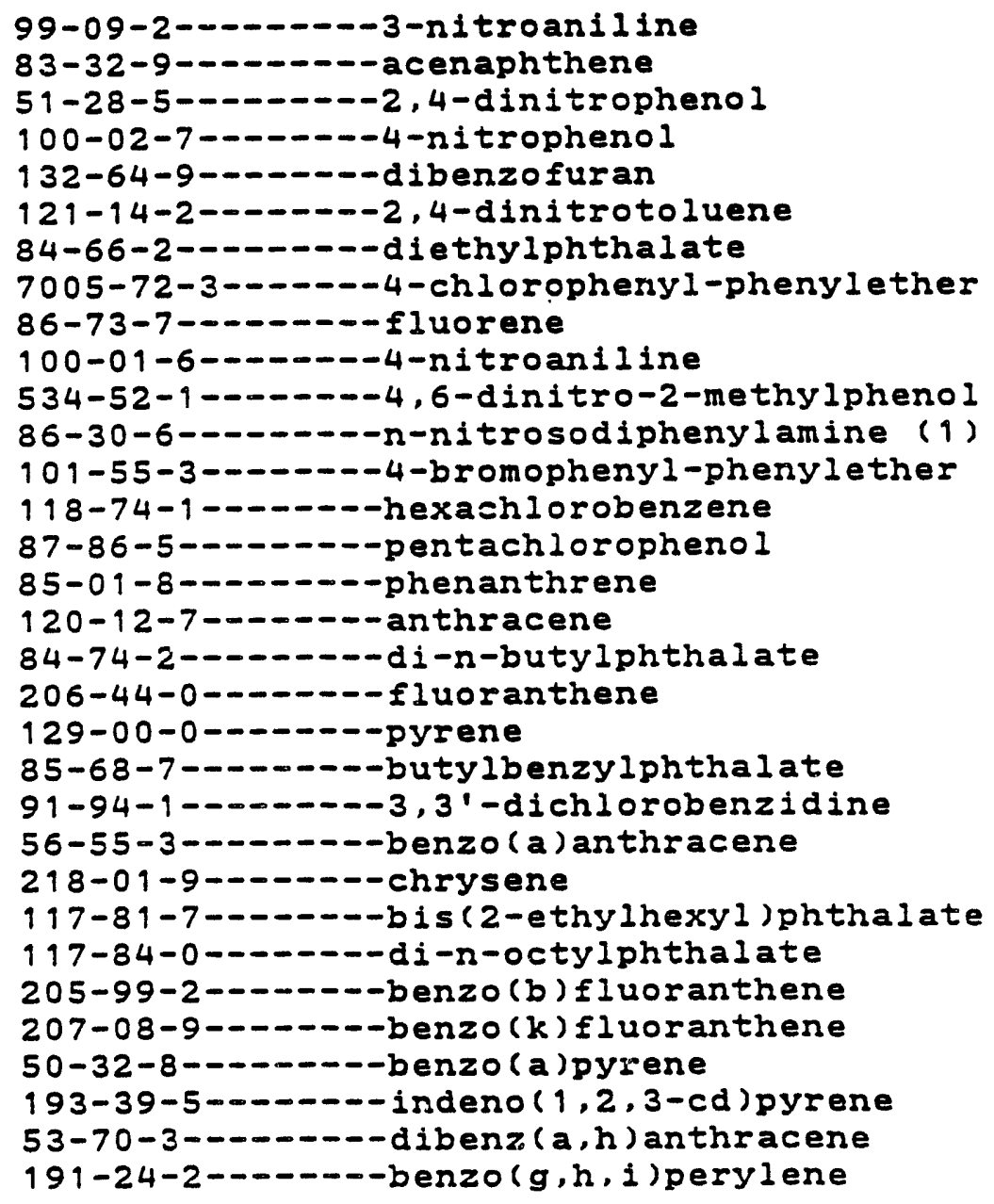 \\
\hline
\end{tabular}

(i) - Cannot be separated from Diphenylamine
5000

1000 .

5000 .

5000 .

1000 .

1000 .

1000 .

1000

1000 .

5000

5000 .

1000 .

1000 .

1000

5000 .

1200 .

1000 .

1000 .

1000

1000

1000 .

2000.

1000

1000

1000 .

1000 .

1000 .

1000 .

1000.

1000 .

1000 .

1000 . 
Semivolatile organic Analysis Data

Request Number: OAL94146

EPA SAMPLE NO.

Procedure Number: 8240 Matrix: SOIL \& WATER

Series:

Frequency: ON REQUEST

Charge Number:

33357130

Customer Name: SIEGRIST

Sample wt/vol: .1 G

Date Sampled: 19-Feb-1991

\% Moisture: not dec.

Material Description FUEL

Number IICs found: 20
Lab Sample ID: 910228-071

Lab File ID: $\quad>C 3566$

Date Received 27-Feb-1991 14:30

dec:

Date Analyzed: 20-Mar-1991

Date of Report: 2-MAY-91

CONCENTRATION UNITS: (UG/L Or UG/KG) UG/L

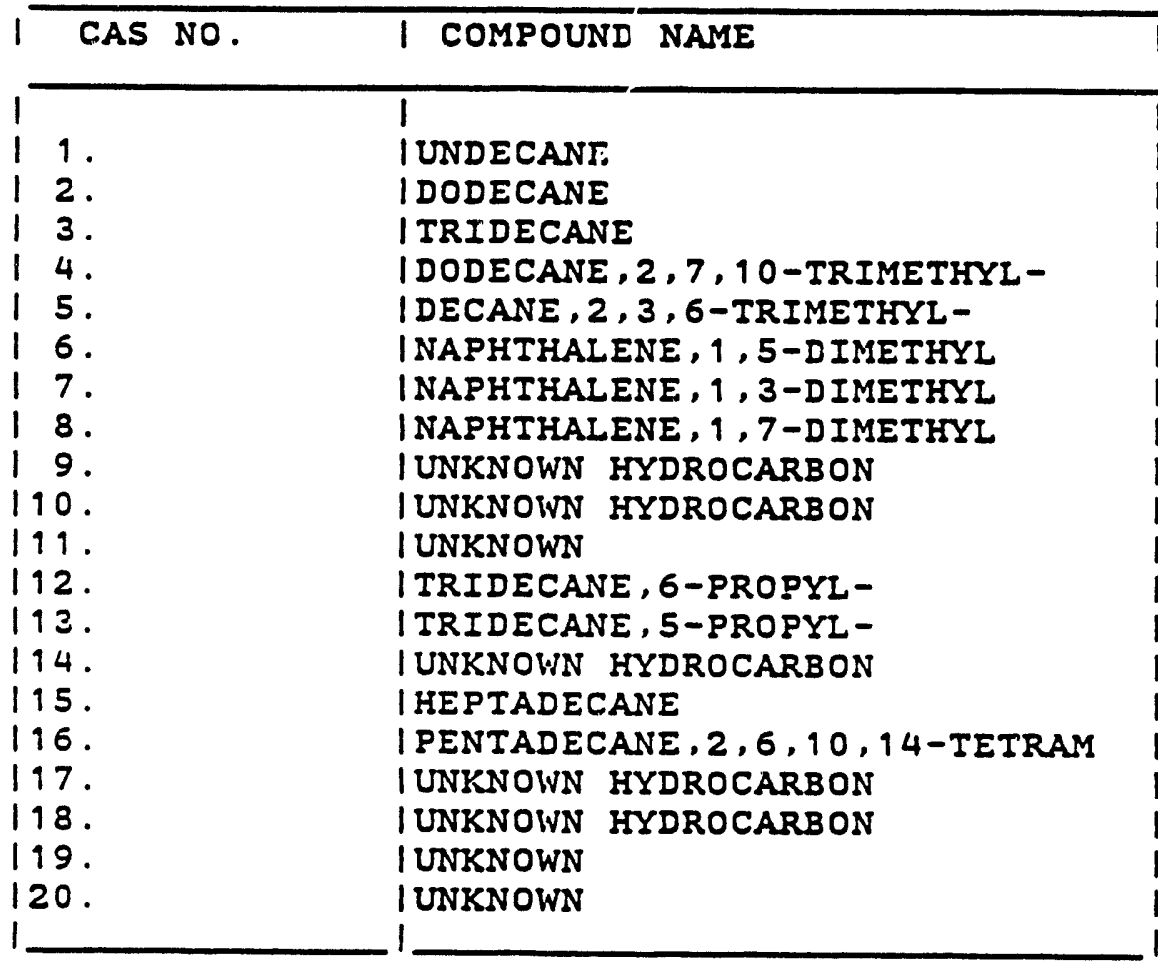

Reviewed by:

RT I CONC IQ ।

15.65

17.72

19.66

21.03

21.48

21.82

22.10

22.16

22.35

22.52

24.07

24.79

25.50

25.70

26.30

26.37

26.88

27.72

29.08

30.37

Date :

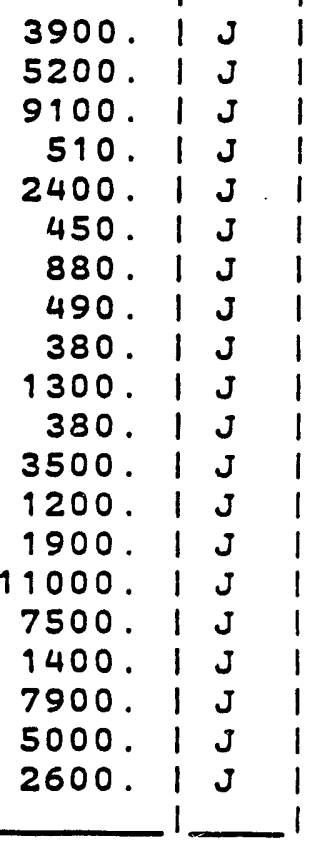

$3900.1 \mathrm{~J}$ $450.1 \mathrm{~J}$ $380.1 \mathrm{~J}$ $1300.1 \mathrm{~J}$ $1500.1 \mathrm{~J}$ 1200 1900 . 11000 7500 . 1400 7900 5000 . 1 
Lab Name: Oak Ridge National Lab Lab Code: Case no: ORNL

Matrix: (soil/water) WATER

Sample wt/vol: $5 \mathrm{ML}$

Level: (low/med) Low

\% Moisture: not dec.

Column: (pack/cap) PACK
Contract: NR

SAS NO: NR

\section{TBO3}

SDG NO: 6228
Lab Sample ID: 910228-072

Lab File ID: $\quad>$ G2112

Date Received 28-Feb-1991

Date Aralyzed: 28-Feb-1991

Dilution Factor: $\quad 1.0$

CAS NO. COMPOUND

CONCENTRATION UNITS:

(UG/L OY UG/KG) UG/L

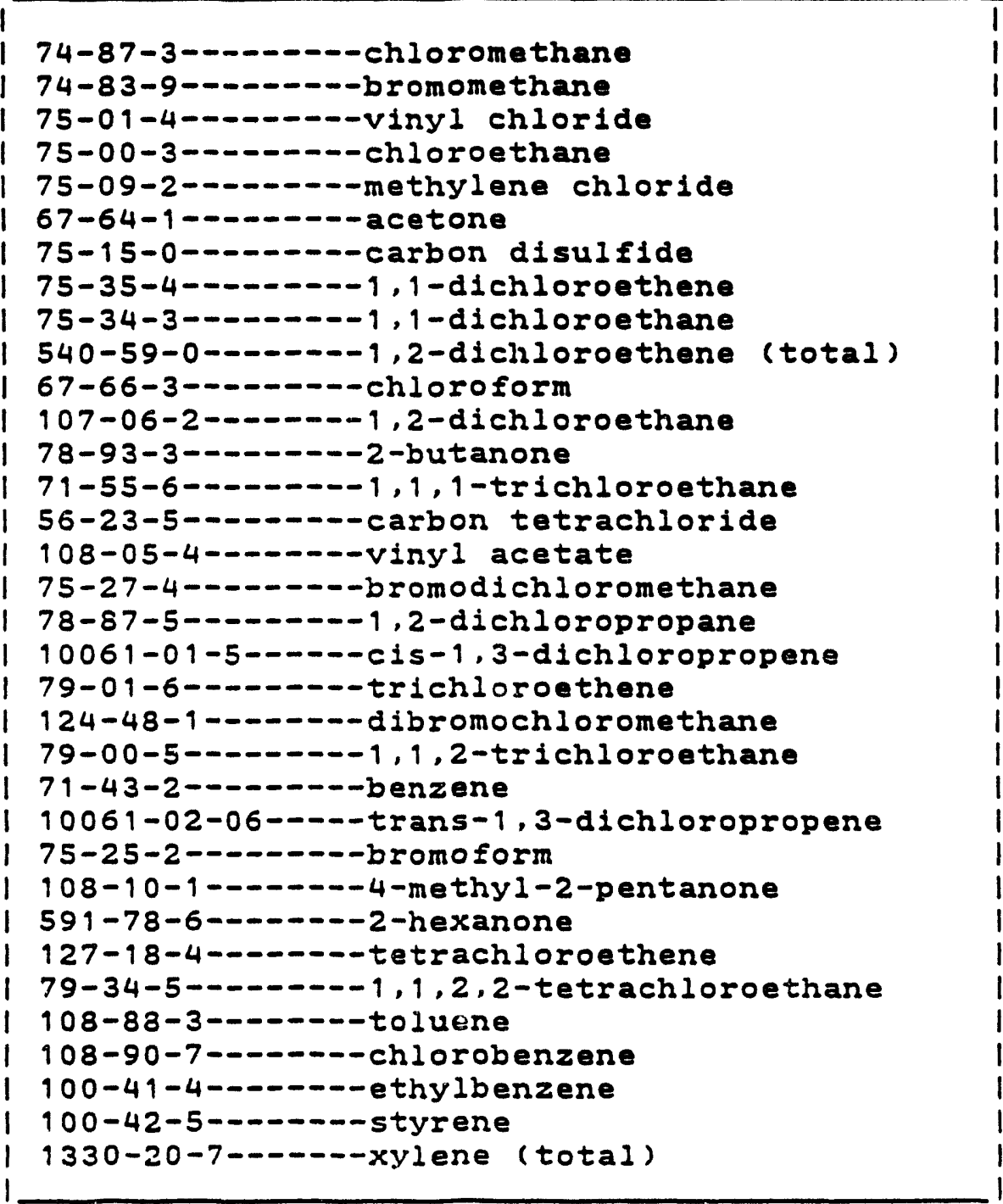

Reviewed by:

10.

10.

10 .

10 .

1.00

10 .

5.00

5.00

5.00

5.00

5.00

5.00

10 .

5.00

5.00

10 .

5.00

5.00

5.00

5.00

5.00

5.00

5.00

5.00

5.00

10.

10.

5.00

5.00

5.00

5.00

5.00

5.00

5.00 
Lab Name:OAK RIDGE NATIONAL LAB

Lab Code: OR

Case No.: NR

Matrix: (soil/water) soIL

Sample wt/vol: $\quad 30.9(\mathrm{~g} / \mathrm{mL})$ G

Level: (low/med) IOW

\% Moisture: not dec.NR

dec. NR

Extraction: (Sepe/Cont/Sonc) soNC GPC Cleanup: $(\mathrm{Y} / \mathrm{N}) \mathrm{N} \quad \mathrm{pH}: \mathrm{NR}$
Contract: NR

SAS NO.: NR
Lab Sample ID: 910228-062MS

Lab File ID: $\quad>C 3556$

Date Received: $2 / 28 / 91$

Date Extracted:3/08/91

Date Analyzed: 3/19/91

Dilution Factor: 100.

CAS NO.

COMPOUND

CONCENTRATION UNITS :

(ug/L or $u g / \mathrm{Kg}$ ) $\mathrm{mg} / \mathrm{Kg}$

Q

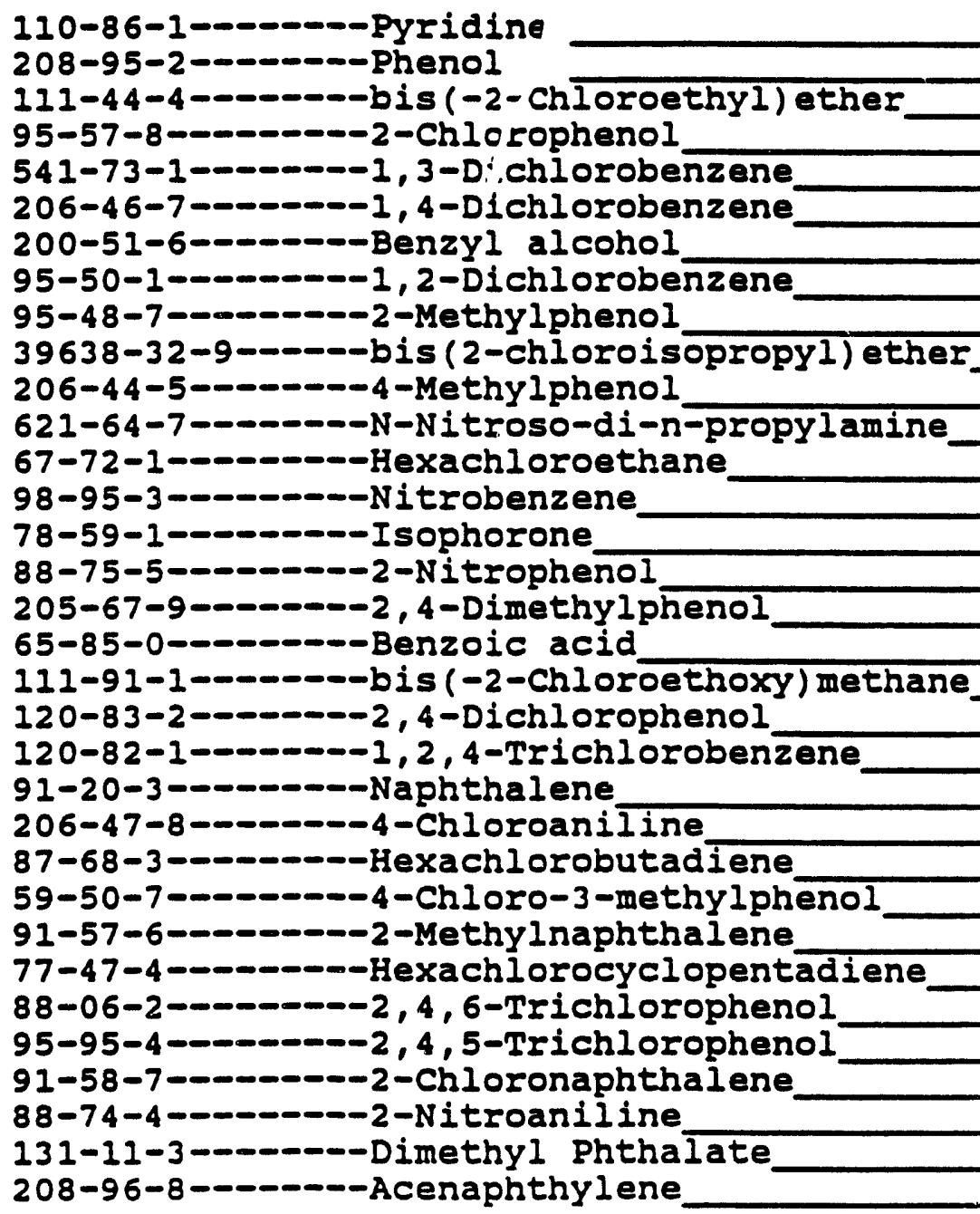

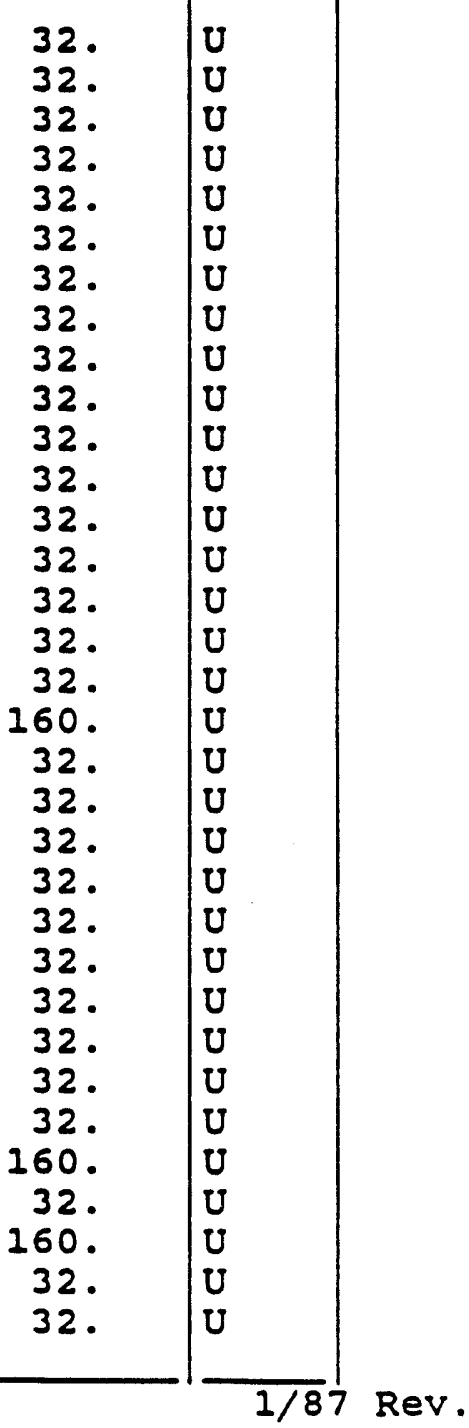


Lab Name:OAK RIDGE NATIONAL IAB

Lab Code: OR

Case No.: NR

Matrix: (soil/water) soII

Sample wt/vol: $\quad 30.9(\mathrm{~g} / \mathrm{mL}) \mathrm{G}$

Level: (low/med) LOW

\& Moisture: not dec.NR

dec. NR

Extraction: (Sepf/Cont/Sonc) SONC

GPC Cleanup: $(Y / N) N \quad$ PH:NR
Contract:NR

SAS NO.: NR
910228-062MS

SDG NO.: $C 319$

Lab Sample ID: 910228-062MS

Lab File ID: $>C 3556$

Date Received: 2/28/91

Date Extracted:3/08/91

Date Analyzed: 3/19/91

Dilution Factor: 100.

CONCENTRATION UNITS:

CAS NO. COMPOUND (ug/L or $\mathrm{ug} / \mathrm{Kg}$ ) $\mathrm{mg} / \mathrm{Kg}$

2

606-20-2-- - - - 2,6-Dinitrotoluene

99-09-2-- - - - - 3-Nitroaniline.

83-32-9-- - - - Acenaphthene

$51-28-5-\ldots-\infty-2,4-$ Dinitrophenol

200-02-7-- - - - 4-Nitrophenol

132-64-9------Dibenzofuran

121-14-2---- - 2, 4-Dinitrotoluene

84-66-2--- - - -Diethylphthalate

7005-72-3-- - - 4-Chloropheny l-phenylether

86-73-7--- - - Fluorene

200-01-6--- - - 4-Nitroaniline

534-52-1-------4, 6-Dinitro-2-methylphenol

86-30-6- - - N-Nitrosodiphenylamine (1)

201-55-3---- -4-Bromophenyl-phenylether

118-74-1-n-_--Hexachlorobenzene

87-86-5--- - - - Pentachlorophenol

85-01-8-------Phenanthrene

120-12-7--n---Anthracene

84-74-2-- - - - Di-n-butylphthalate

206-44-0--n---Fluoranthene

129-00-0-------pyrene

85-68-7 - - - - Butylbenzylphthalate

91-94-1-- - - - - 3, 3'-Dichlorobenzidine

56-55-3-- - - - Benzo (a) anthracene

218-01-9------Chrysene

117-81-7-_-_-bis (2-Ethylhexyl) phthalate

117-84-0---- -Di-n-octyl phthalate

205-99-2------Benzo (b) fluoranthene

207-08-9------Benzo (k) Iluoranthene

50-32-8- - - - Benzo (a) pyrene

193-39-5-_-_--Indeno $(1,2,3-c d)$ pyrene

53-70-3-- - - Dibenzo $(a, h)$ anthracene

191-24-2-- - - Benzo $(9, h, i)$ perylene

(1) - Cannot be separated from Diphenylamine FORM I SV-2

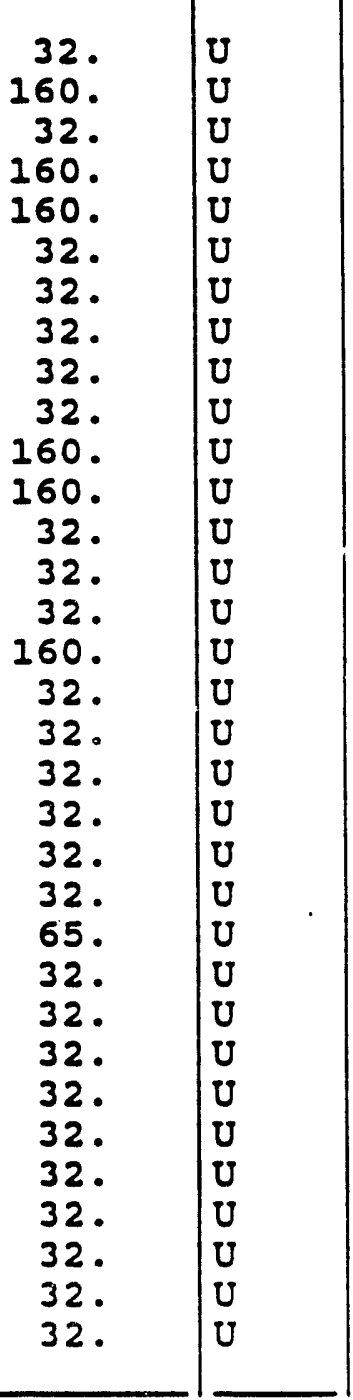

$1 / 87$ Rev. 


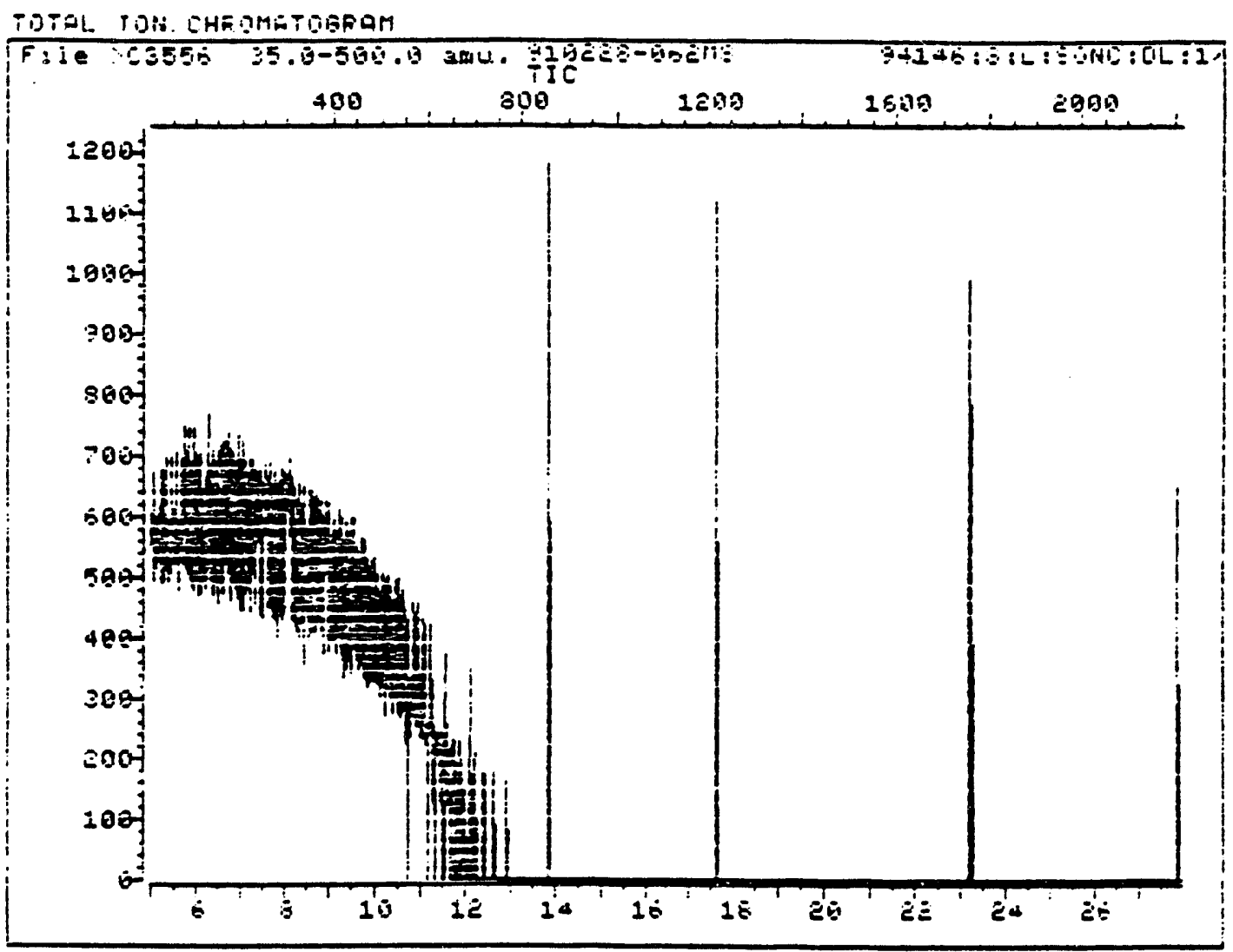

Fato File: D555e: :02

Name: $1023-102 M$

MI3C: OAI HE:S:L:SDME:DL:L.100

[uant Duqput File: L5550::0!

E!: $:$

IaF:

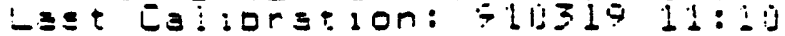

Gopraror IE: SANDPA

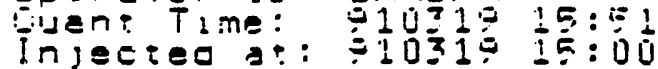

TIE page 1 of 


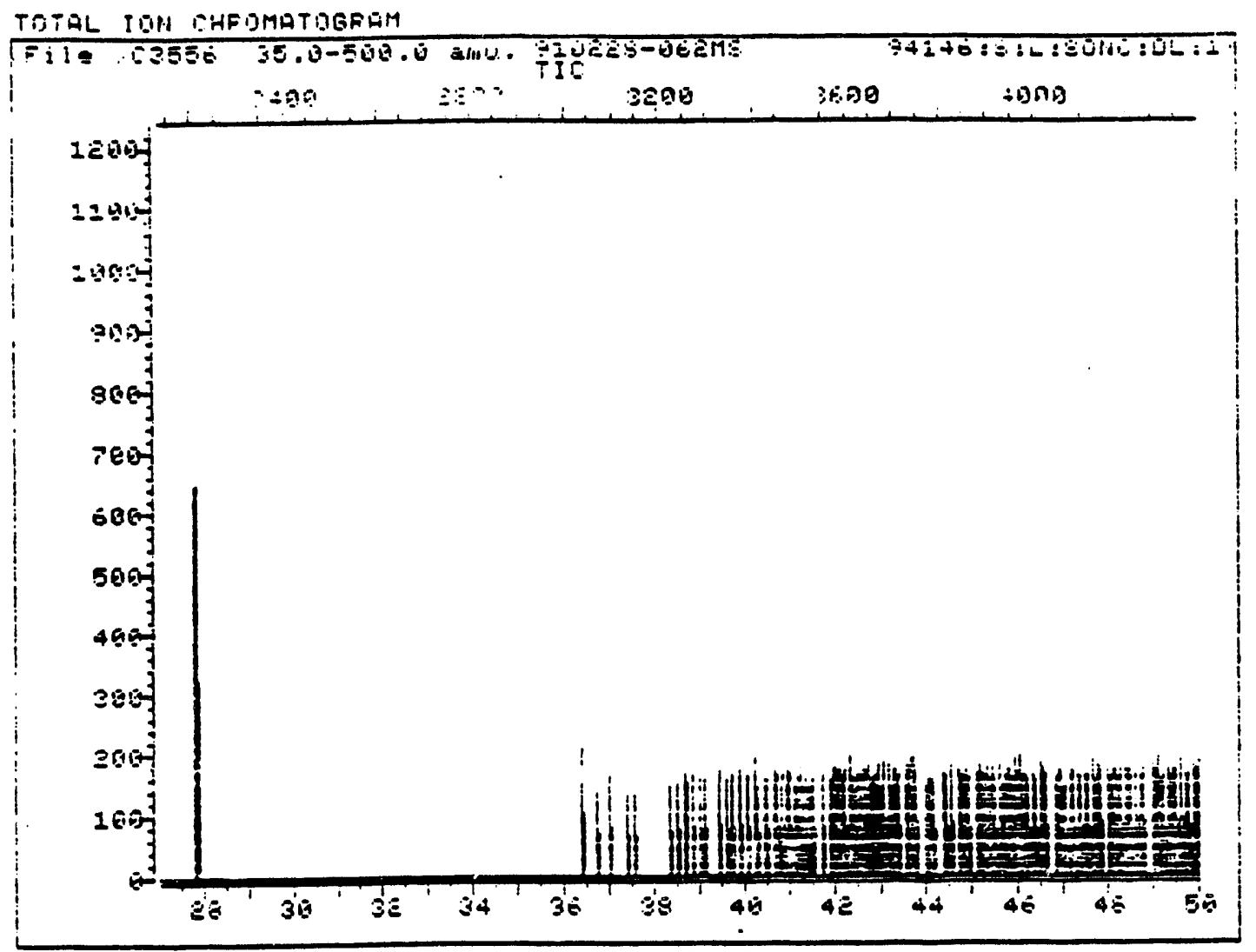

Liata $F_{i} l=:$ : E:55e: :

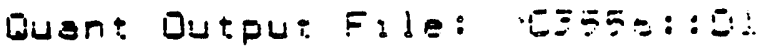

Name: $9112: 2 B=1]$ M ME

IA

Last Ealibretion: 910317 il: io

Geerater IL: SHNQRA

Duan: Time: J10:19 15:51

Injec:ed : : :1031 $15: 00$

TIE page? $2+?$ 


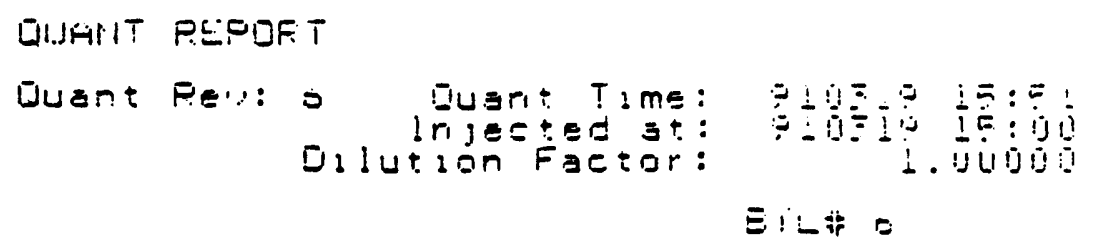


Lab Name:OAK RIDGE NATIONAL IAB

Lab Code: OR

Case No.: NR

Matrix: (soil/water) soII

Sample wt/vol: $\quad 30.9(\mathrm{~g} / \mathrm{mL}) \mathrm{G}$

Level: (low/med) LOW

\% Moisture: not dec.NR

dec. NR

Extraction: (Sepf/Cont/Sonc) soNC

GPC Cleanup: $(\mathrm{Y} / \mathrm{N}) \mathrm{N} \quad \mathrm{pH}: \mathrm{NR}$
Contract: NR

SAS NO.: NR
SDG NO.: 6319

Lab Sample ID: 910228-062MSD

Lab File ID: $\quad>C 3557$

Date Received: 2/28/91

Date Extracted:3/08/91

Date Analyzed: $3 / 19 / 91$

Dilution Factor: 100.

CAS NO. COMPOUND (ug/L or $u g / \mathrm{kg}) \mathrm{mg} / \mathrm{Kg}$

CONCENTRATION UNITS:
(ug/L OI $u g / \mathrm{Kg}$ ) $\mathrm{mg} / \mathrm{Kg}$

Q

110-86-1-- - - - Pyridine

208-95-2---_---Phenol

$111-44-4-\infty-\ldots--b i s(-2-c h$ loroethyl) ether

95-57-8-------2-Chlorophenol

541-73-1-- - - 1, 3-Dichlorobeñzene

206-46-7-- - - 1, 4-Dichlorobenzene

200-51-6-- - - Benzyl al cohol

95-50-1-n- - - 1, 2-Dichlorobenzene

95-48-7- - - - 2-Methylphenol

39638-32-9--n-bis (2-chloroisopropyl) ether

206-44-5-n- - 4-Methylphenol

621-64-7-n-n-N-Nitroso-di-n-propylamine

67-72-1-- - - Hexachloroethane

98-95-3-------Nitrobenzene

78-59-1-n-n-- Isophorone

88-75-5---- - - 2-Nitrophenol

205-67-9--- - - 2, 4-Dimethylphenol

65-85-0-- - - - Benzoic acid

111-91-1--- - bis (-2-Chloroethoxy) methane

120-83-2-- - - - 2, 4-Dichlorophenol

$120-82-1--\infty--1,2,4-$ Trichlorobenzene

91-20-3-n-n- Naphthalene

206-47-8-- - - 4-Chloroaniline

87-68-3-n-n-- Hexachlorobutadiene

59-50-7-- - - -4-Chloro-3-methylphenol

91-57-6- - - - 2-Methylnaphthalene

77-47-4-- - - Hexachlorocyclopentadiene

88-06-2-n-----2, 4, 6-Trichlorophenol

95-95-4-- - - - 2, 4, 5-Trichlorophenol

91-58-7-- - - - 2-Chloronaphthalene

88-74-4-- - - - 2-Nitroaniline

131-11-3-----Dimethyl Phthalate 208-96-8------Acenaphthylene

$$
\text { FORM I SV-I }
$$

\begin{tabular}{|c|c|}
\hline 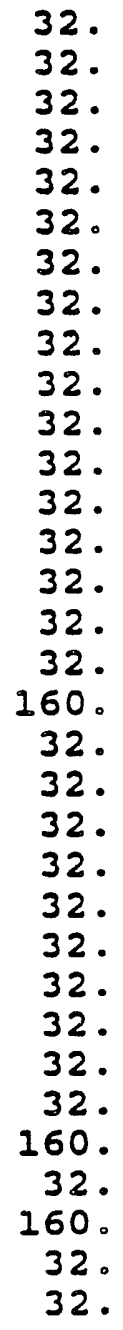 & $\begin{array}{l}U \\
U \\
U \\
U \\
U \\
U \\
U \\
U \\
U \\
U \\
U \\
U \\
U \\
U \\
U \\
U \\
U \\
U \\
U \\
U \\
U \\
U \\
U \\
U \\
U \\
U \\
U \\
U \\
U \\
U \\
U \\
U \\
U\end{array}$ \\
\hline
\end{tabular}




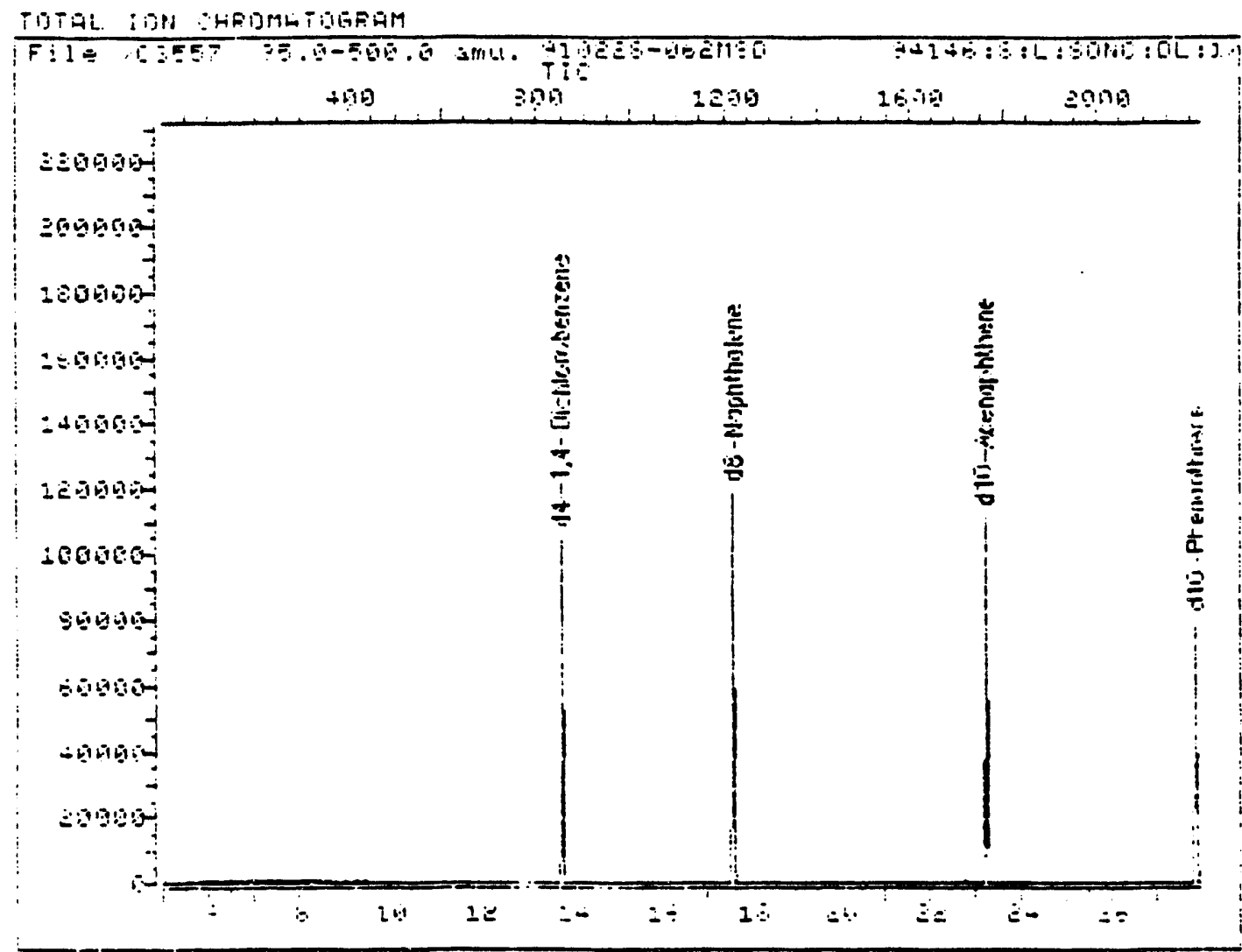

Uะ:

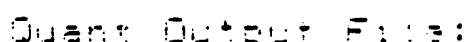

r.

Sus?

$\therefore-\cdots$

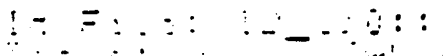

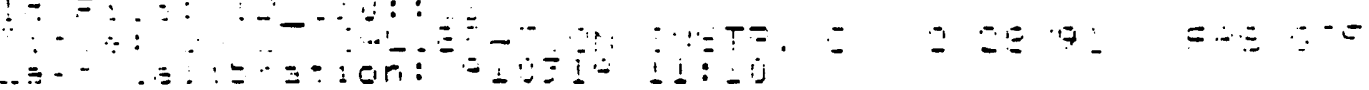

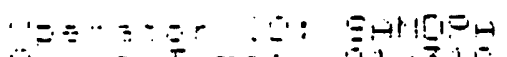

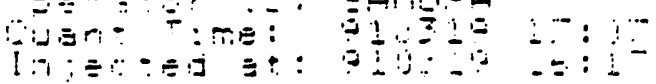

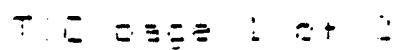




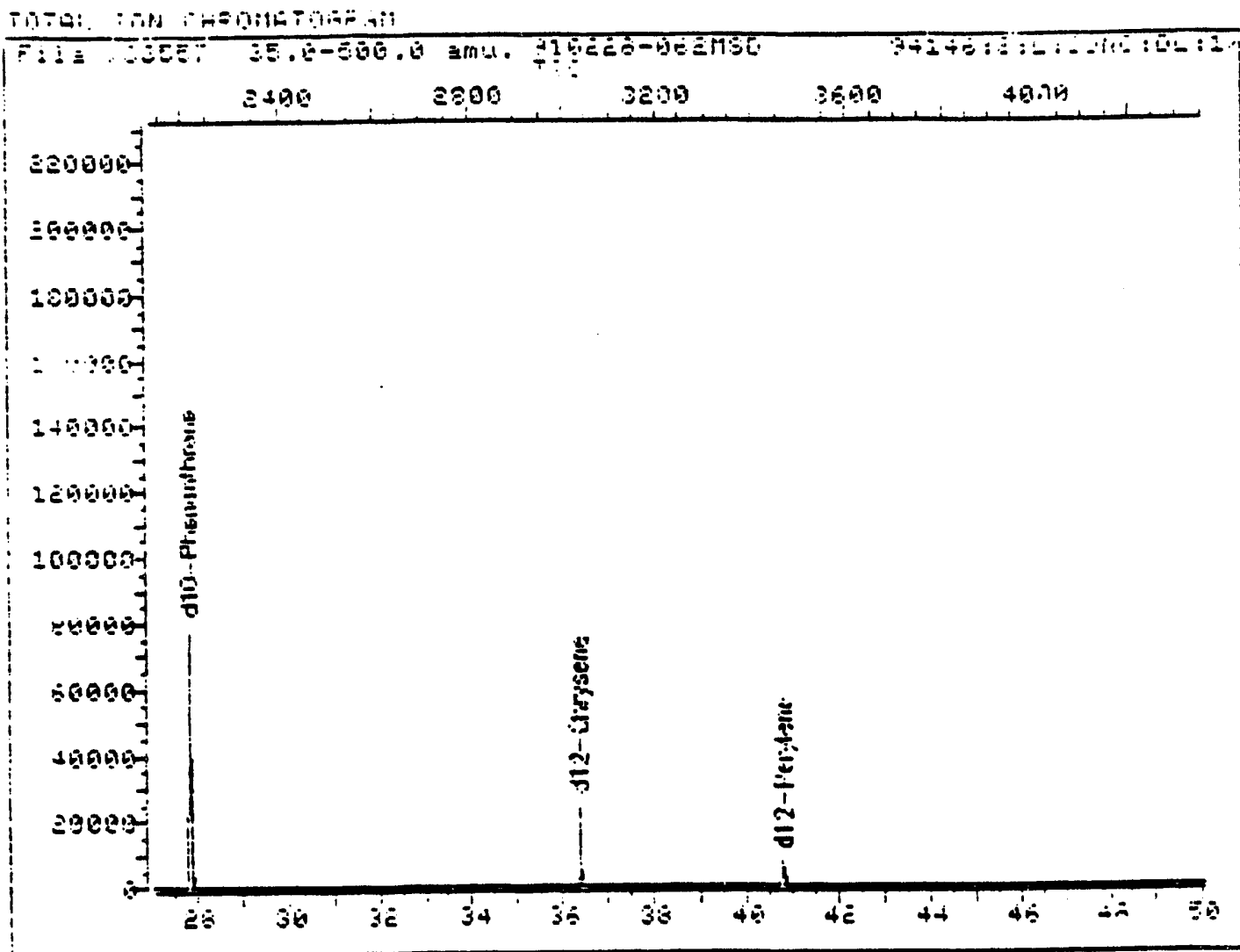

Cia:a Fi je :

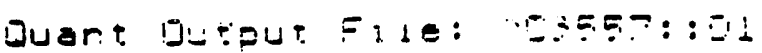

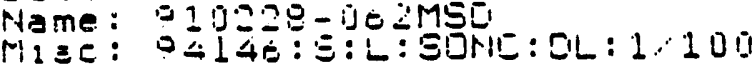

Id : : le:

-as: Gl:=ration:

Goerstar If: EnNGFE

Injected

TiE page of of 2 
DiJAMT FELETT

Dereter If: SHropa

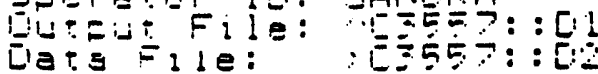

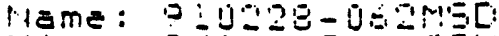

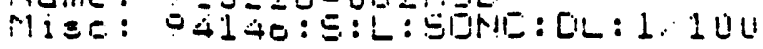

Uuart Tame:

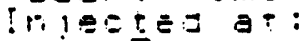
Ellution Fociar:

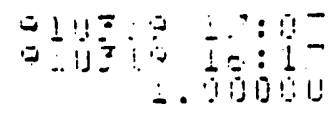

EIL\#

!C File:

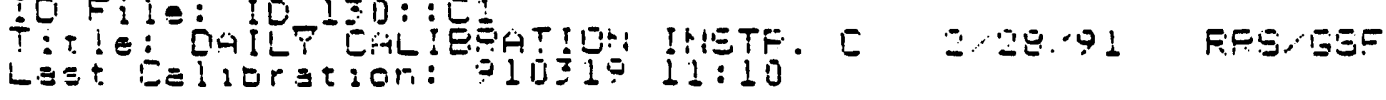

\section{Compound}

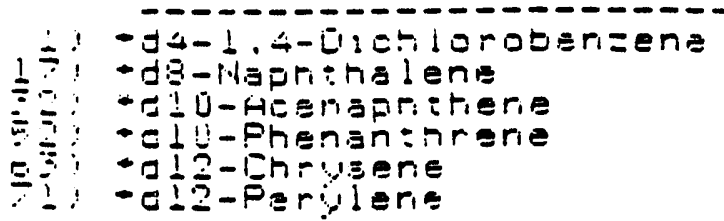

- Lompiolina :s ISTE

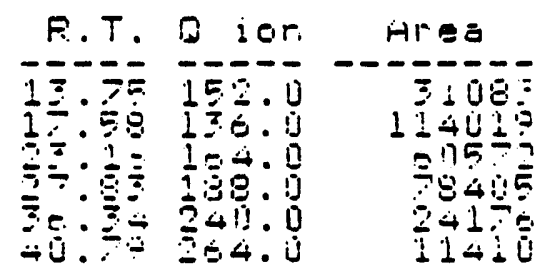

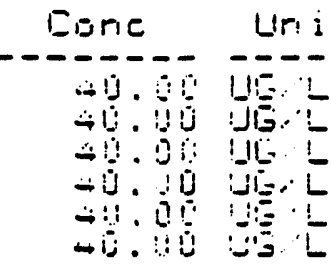




\section{VOLATILE ORGANICS ANALYSIS DATA SHEET}

LAB NAME: OAK RIDGE NATIONAL LAB LAB CODE:

CASE NO: ORNL MATRIX: (SOIL/WATER) WATER

SAMPLE WT/VOL:

$5 \mathrm{ML}$

LEVEL : (LOW/MED) LOW

\% moisture: not dec.

COL.UMN: (PACK/CAP) CAP
CONTRACT: NR

SAS NO: NR

\section{TBO 1}

SDG NO: 0309
LAB SAMPLE ID: 910307-149

LAB FILE ID: $\quad>01218$

DATE RECEIVED 7-MAR-1991

DATE ANALYZED: 9-MAR-1991

DILUTION FACTOR: $\quad 1.0$

CAS NO.

COMPOUND

CONCENTRATION UNITS: (UG/L OR UG/KG) UG/L

Q

\begin{tabular}{|c|c|c|}
\hline 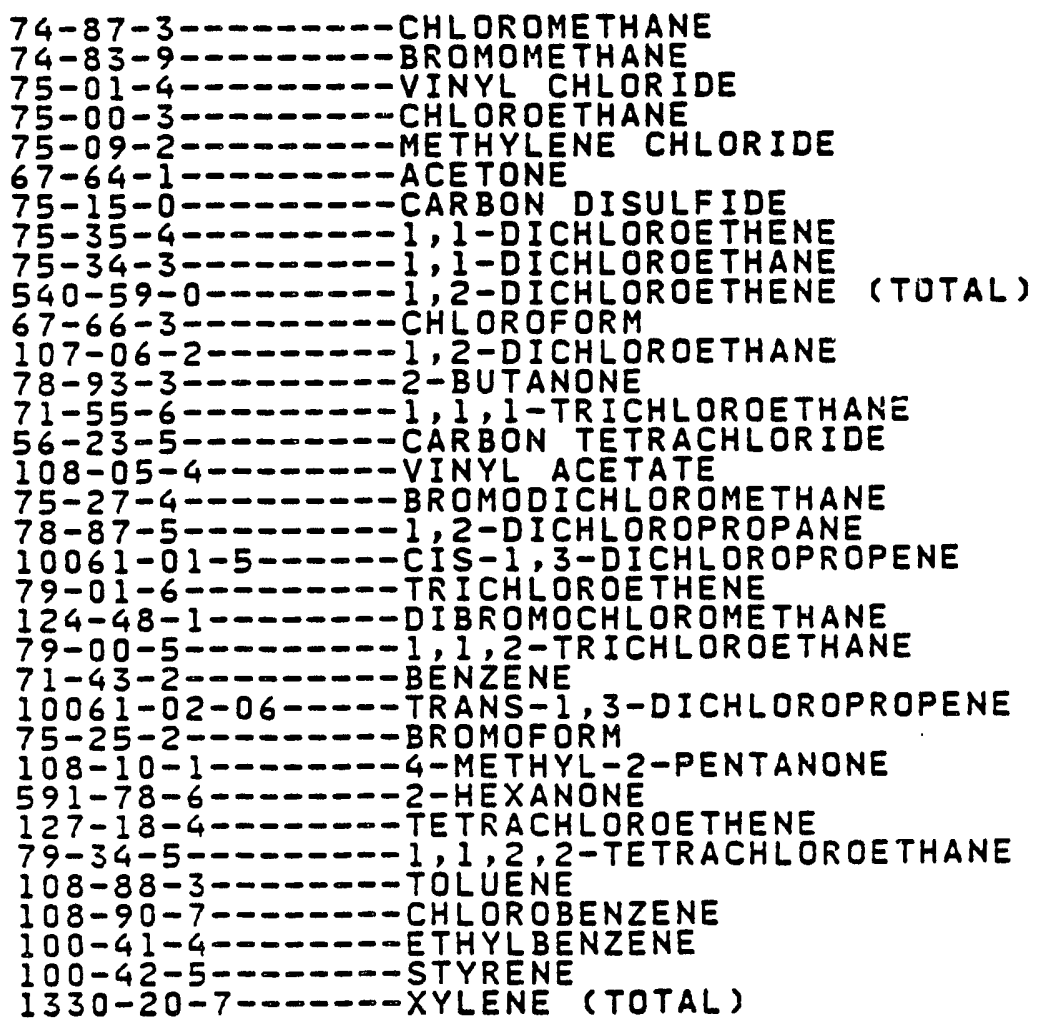 & 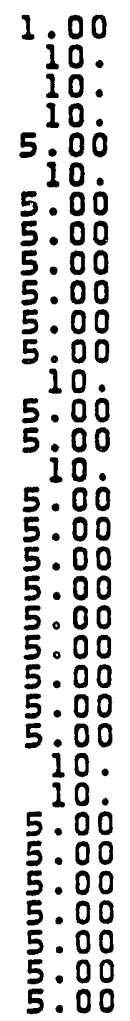 & 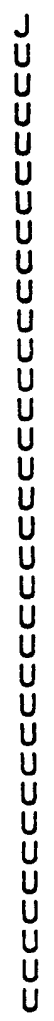 \\
\hline
\end{tabular}


VOLATILE ORGANICS ANALYSIS DATA SHEET

EPA SAMPLE NO.

LAB NAME: OAK RIDGE NATIONAL LAB CONTRACT: NR

TBO2

LAB CODE :

CASE NO: ORNL

SAS NO: NR

SDG NO: 0309

MATRIX: (SOIL/WATER) WATER

SAMPLE WT/VOL: $5 \mathrm{ML}$

LAB SAMPLE ID: $910307-150$

LEVEL: (LOW/MED) LOW

LAB FILE ID: >01219

\% moIstuRE: NOT dec.

DATE RECEIVED 7-MAR-1991

COLUMN: (PACK/CAP) CAP

DATE ANALYZED: 9-MAR-1991

DILUTION FACTOR: 1.0

CAS NO. COMPOUND CONCENTRATION UNITS:

\begin{tabular}{|c|c|c|}
\hline 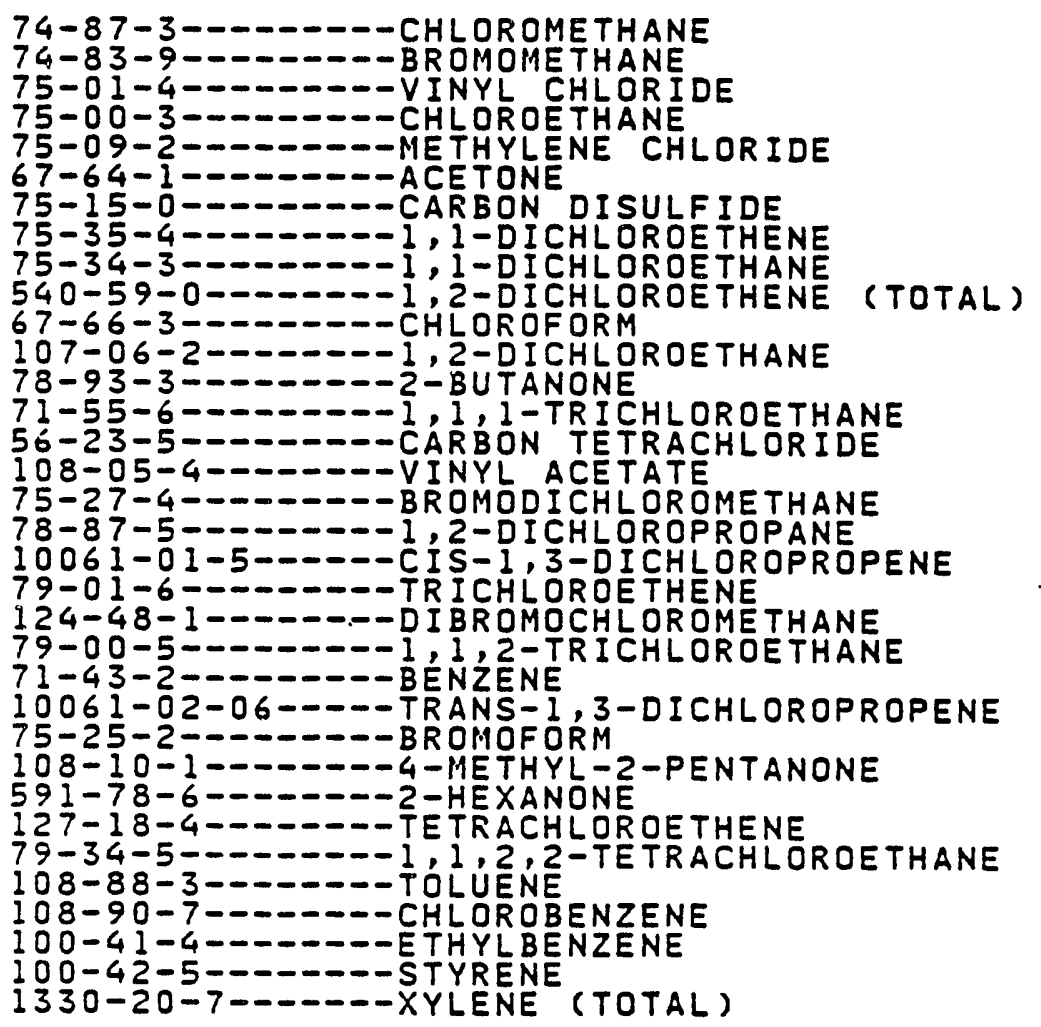 & 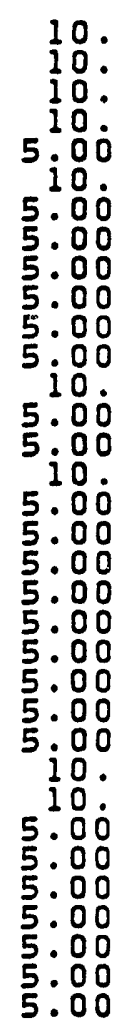 & 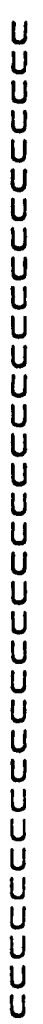 \\
\hline
\end{tabular}


LAB NAME: OAK RIDGE NATIONAL LAB CONTRACT: NR

LAB CODE: CASE NO: ORNL

MATRIX: (SOIL/WATER) WATER

SAMPLE WT/VOL: $\quad 5 \mathrm{ML}$

LEVEL: (LOW/MED) LOW

\% MOISTURE: NOT DEC.

COLUMN: (PACK/CAP) CAP

SAS NO: NR SDG NO: 0309

LAB SAMPLE ID: $910307-151$

LAB FILE ID: >01220

DATE RECEIVED 7-MAR-1991

DATE ANALYZED: 9-MAR-1991

DILUTION FACTOR: 1.0

CONCENTRATION UNITS:

(UG/L OR UG/KG) UG/L

\begin{tabular}{|c|c|c|c|}
\hline CAS NO. & $\angle U G / L$ OR UG & & $Q$ \\
\hline 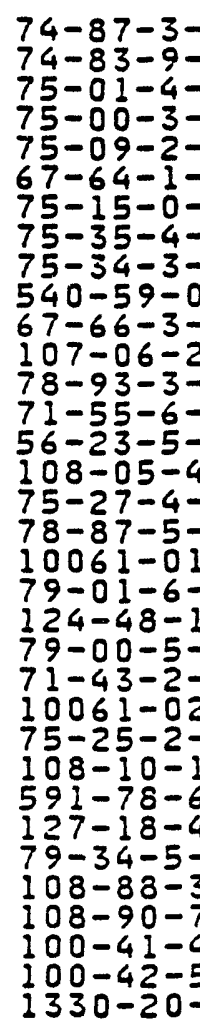 & 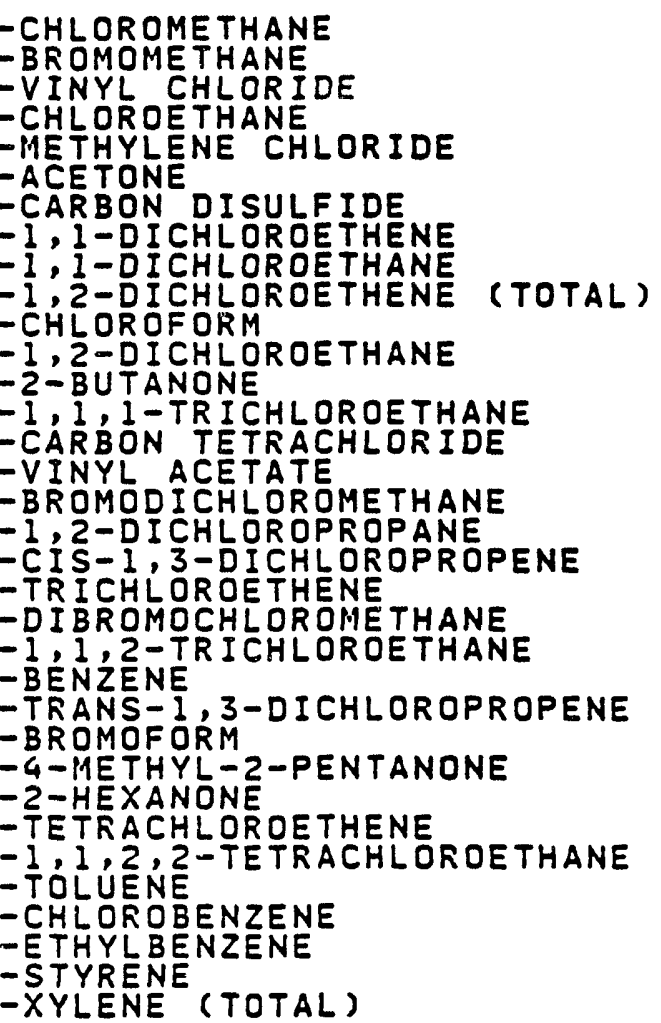 & 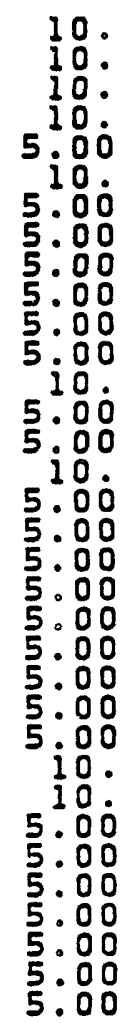 & 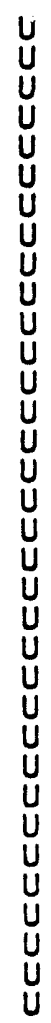 \\
\hline
\end{tabular}


LAB NAME: OAK RIDGE NATIONAL LAB CONTRACT: LAB CODE: CASE NO: ORNL SAS NO: MATRIX: (SOIL/WATER) WATER

SAMPLE WT/VOL: $5 \mathrm{ML}$

LEVEL: (LOW/MED) LOW

$\because$ MOISTURE: NOT DEC.

COLUMN: (PACK/CAP) CAP
TBO5

SDG NO: 0309

LAB SAMPLE ID: $910307-152$

LAB FILE ID: >01221

DATE RECEIVED 7-MAR-1991

DATE ANALYZED: 29-APR-1991

DILUTION FACTOR: 1.0

CONCENTRATION UNITS:

CAS NO. COMPOUND (UG/L OR UG/KG) UG/L

Q

\begin{tabular}{|c|}
\hline 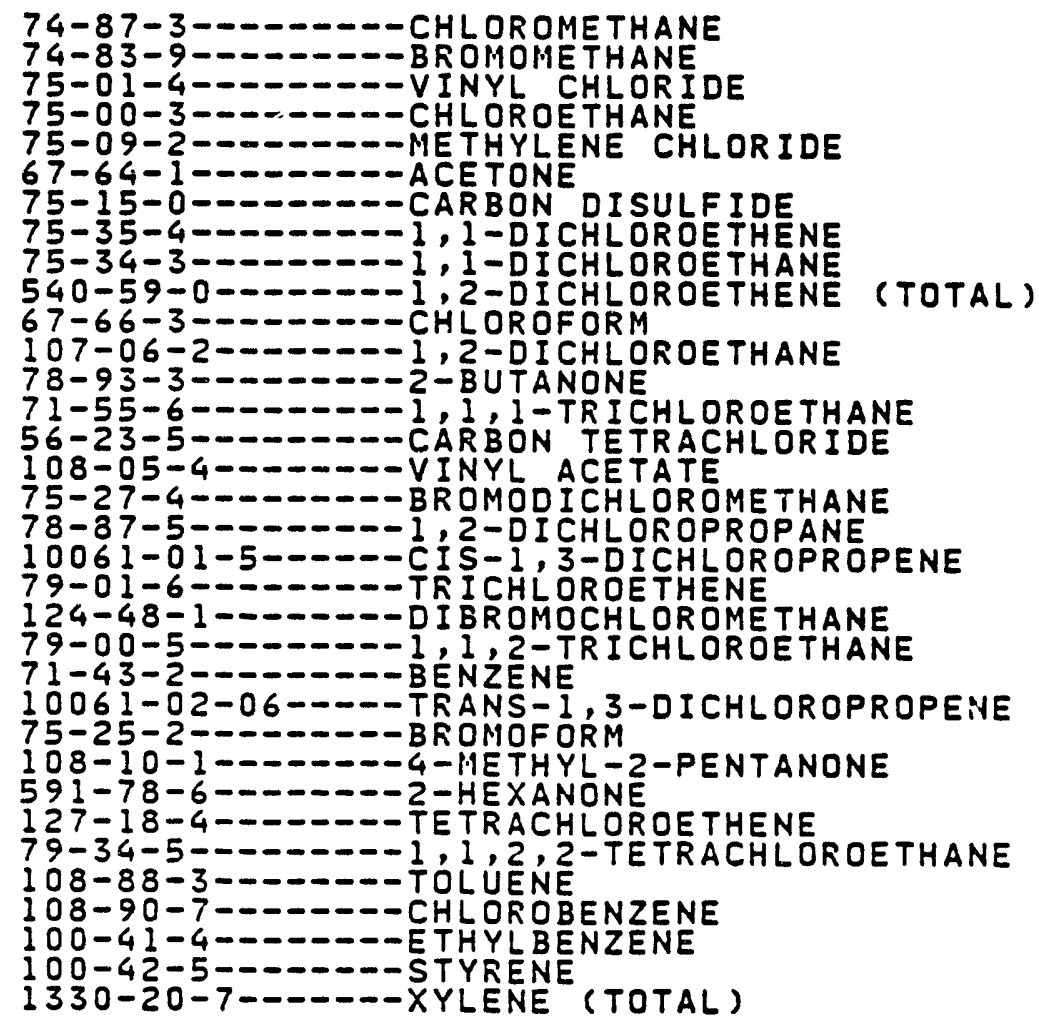 \\
\hline
\end{tabular}

REVIEWED BY:

\begin{tabular}{|c|c|}
\hline 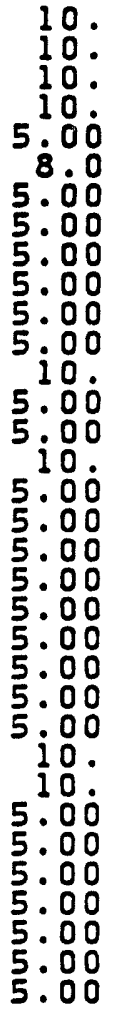 & $\begin{array}{l}U \\
U \\
U \\
U \\
U \\
J \\
U \\
U \\
U \\
U \\
U \\
U \\
U \\
U \\
U \\
U \\
U \\
U \\
U \\
U \\
U \\
U \\
U \\
U \\
U \\
U \\
U \\
U \\
U \\
U \\
U\end{array}$ \\
\hline
\end{tabular}

DATE : 
VOLATILE ORGANICS ANALYSIS DATA SHEET

EPA SAMPLE NO.

LAB NAME: OAK RIDGE NATIONAL LAB CONTRACT: NR

TBO6

LAB CODE

CASE NO: ORNL

SAS NO: NR

SDG NO: 0309

MATRIX: (SOIL/WATER) WATER

LAB SAMPLE ID: 910307-153

SAMPLE WT/VOL:

$5 \mathrm{ML}$

LAB FILE ID: $>01222$

LEVEL: (LOW/MED) LOW

DATE RECEIVED 7-MAR-1991

$\because$ MOISTURE: NOT DEC.

DATE ANALYZED: 9-MAR-1991

COLUMN: (PACK/CAP) CAP

DILUTION FACTOR: 1.0

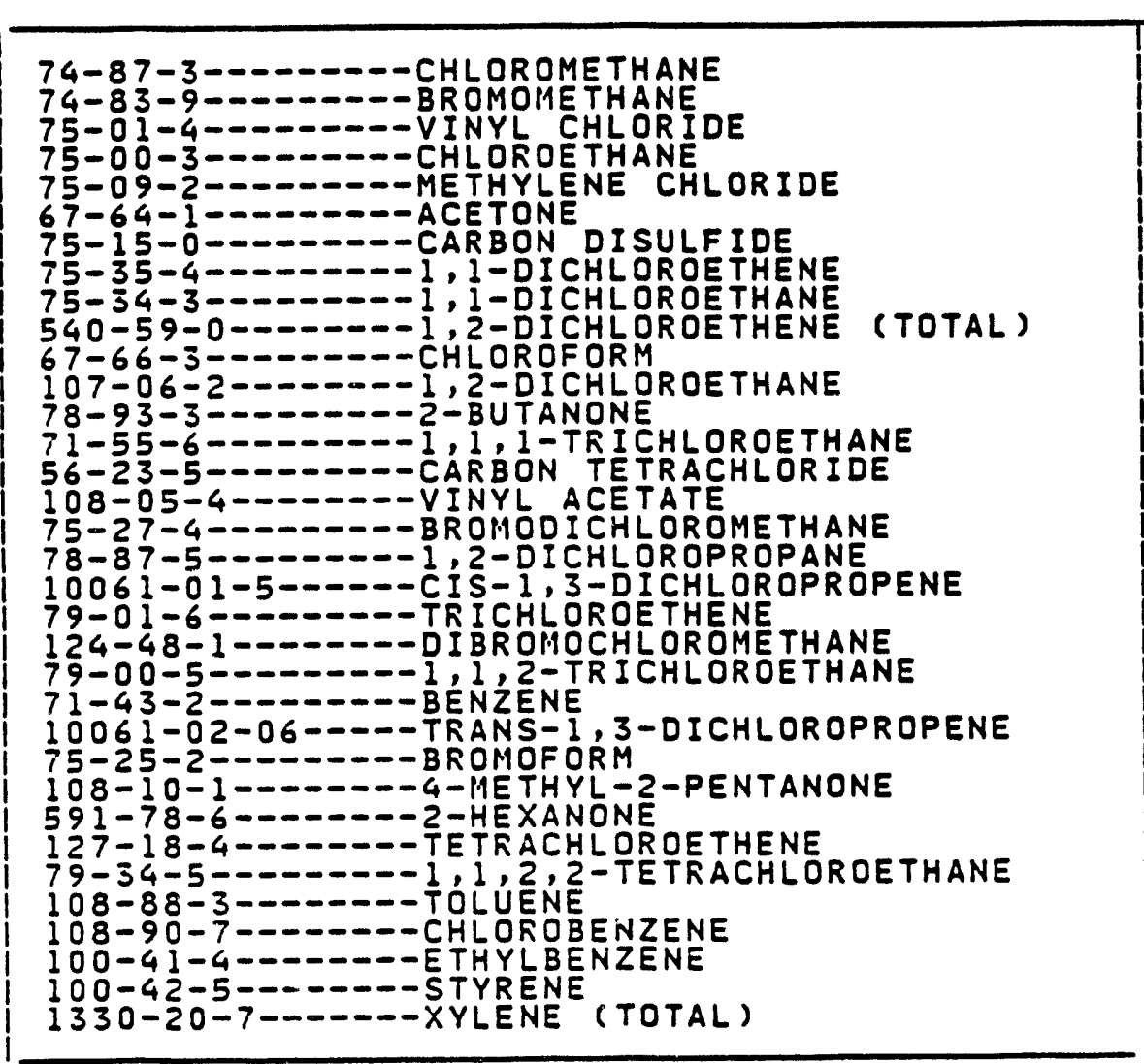

REVIEWED BY:

10 .

10 .

10 .

5 io

5.00

5.00

5.00

5.00

5.00

5.00

5.00

5.00

io.

5.00

5.00

5.00

5.00

5.00

5.00

5.00

5.00

5.00

10 .

5.00

5.00

5.00

5.00

5.00

5.00

5.00

Q

\begin{tabular}{l|l|}
5.00 & $U$ \\
\hline DATE :
\end{tabular}




\section{VOLATILE ORGANICS ANALYSIS DATA SHEET}

LAB NAME: DAK RIDGE NATIONAL LAB LAB CODE :

CASE NO: ORNL

MATRIX: (SOIL/WATER) WATER

SAMPLE WT/VOL: $5 \mathrm{ML}$

LEVEL: (LOW/MED) LOW

\% moisture: nOt dec.

COLUMN: (PACK/CAP) CAP
CONTRACT: NR

SAS NO: NR

\section{ER218}

SDG NO: 0309

LAB SAMPLE ID: 910307-154

LAB FILE ID: >01223

DATE RECEIVED 7-MAR-1991

DATE ANALYZED: 9-MAR-1991

DILUTION FACTOR: 1.0

CONCENTRATION UNITS: (UG/L OR UG/KG) UG/L

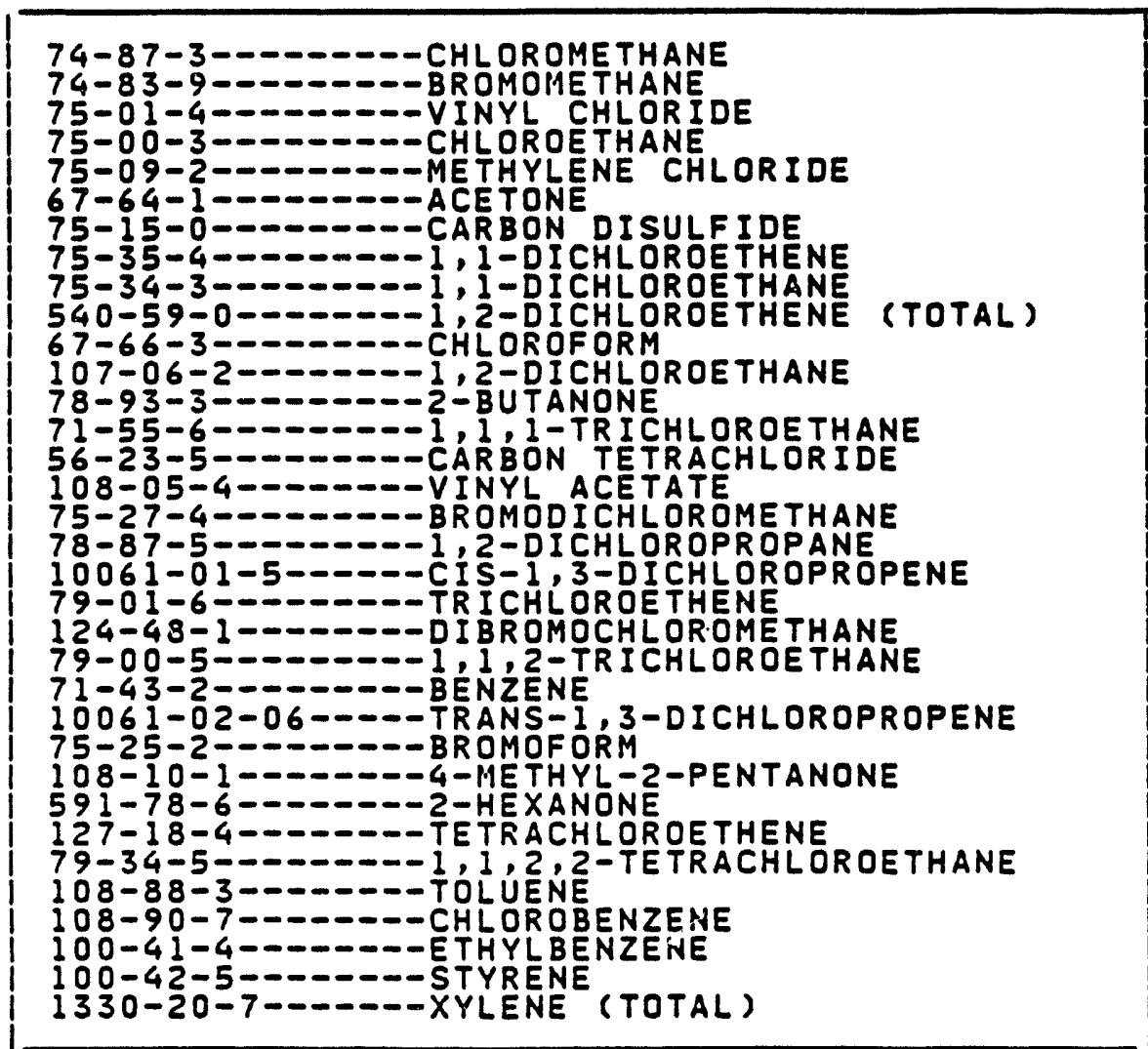

REVIEWED BY:

\begin{tabular}{|c|c|}
\hline $\begin{array}{r}10 . \\
10 \\
100 \\
100 \\
5.00 \\
620 \\
5.00 \\
5.00 \\
5.00 \\
5.000 \\
5.00 \\
100 \\
5.00 \\
5100 \\
5.00 \\
5.00 \\
5.00 \\
5.00 \\
5.00 \\
5.00 \\
5.00 \\
5.00 \\
5.00 \\
100 \\
1.00 \\
5.00 \\
5.00 \\
3.00 \\
1.00 \\
5.00 \\
5.00 \\
5.00\end{array}$ & 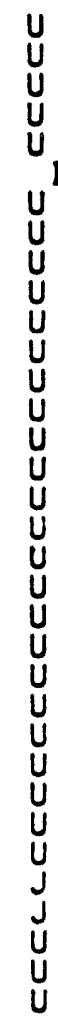 \\
\hline
\end{tabular}


SEMIVOLATILE ORGANIC ANALYSIS DATA

EPA SAMPLE NO.

LAB NAME: OAK RIDGE NATIONAL LAB CONTRACT: NR

LAB CODE: CASE NO: NR

MATRIX: (SOIL/WATER) WATER

SAMPLE WT/VOL: $\quad 100 \mathrm{ML}$

LEVEL: (LOW/MED) LOW

* moisture: not dec. dec.

EXTRACTION: (SEPF/CONT/SONC) SEPF

GPC CLEANUP: $(Y / N) N$

PH: 6.19
SAS NO: NR
ER2 18

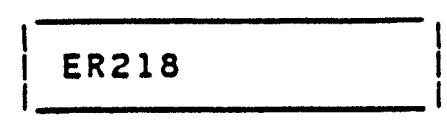

SDG NO: $C 424$

CAS NO. COMPOUND

LAB SAMPLE ID: 910307-154

LAB FILE ID: >C3756

DATE RECEIVED 7-MAR-1991

DATE ANALYZED: 24-APR-1991

DATE EXTRACTED: 13-i:"R-1991

DILUTION FACTOR:

10

CONCENTRATION UNITS: (UG/L OR UG/KG) UG/L

a

108-95-2-------PHENOL

$111-44-4------B I S(2-C H L O R O E T H Y L)$ ETHER

$95-57-8-1-2-C H L O R O P H E N O L$

$541-73-1 \cdots-\cdots-1,3-D I C H L O R O B E N Z E N E$

$106-46-7-\ldots-1,4-D I C H L O R O B E N Z E N E$

$100-51-6-\ldots---1-B E N Z Y L$ ALCOHOL

95-50-1-2.--1,2-DICHLOROBENZENE

$95-48-7-10-10-2$ NETHYLPHENOL

$106-44-5----4-$ ME THYLPHENOL

$621-64-7-0--N-N I T R O S O-D I-N-P R O P Y L A M I N E$

$67-72-1$ -

$98-95-3-\ldots-0-N I T R O B E N Z E N E$

78-59-1----.--I SOPHORONE

$88-75-5=-0-2-N I T R O P H E N O L$

$105-67-9-0--2,4-D I M E T H Y L P H E N O L$

65-85-0------ BENZOIC ACID

II $-91-1=-0$ I $(2-C H L O R O E T H O X Y)$ ME THANE

I20-83-2------ 2,4-DICHLOROPHENOL

$120-82-1-\ldots-\infty-1,2,4-T R$ ICHLOROBENZENE

$91-20-3------N A$ PHTHALENE

$106-47-8-\infty-4-C H L O R O A N I L I N E$

87-68-3-1.--HEXACHLOROBUTADIENE

$59-50-7-0-4-C H L O R O-3-M E T H Y L P H E N O L$

$91-57-6----2-14$ THYLNAPHTHALENE

$77-47-4-10-1 E X A C H L O R O C Y C L O P E N T A D I E N E$

88-06-2---n--2,4,6-TR ICHLOROPHENOL

$95-95-4-\cdots---2,4,5-T R$ I CHLOROPHENOL

$91-53-7-0-0-2-C H L O R O N A P H T H A L E N E$

88-74-4------2-NITROAN IL INE

$131-11-3----0$ IMETHYLPHTHALATE

$208-96-8-1---A C E N A P H T H Y L E N E$

606-20-2------2,6-DINITROTOLUENE

\begin{tabular}{|c|c|}
\hline 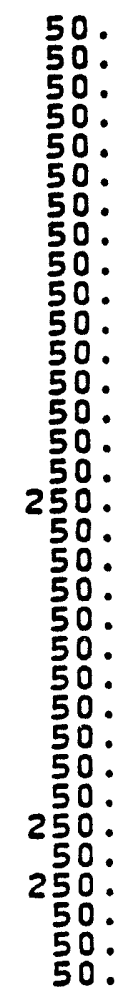 & 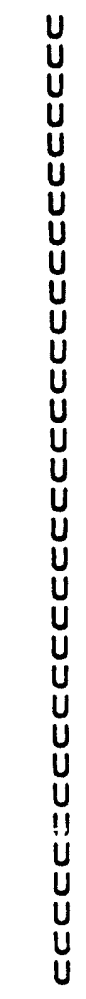 \\
\hline
\end{tabular}


SEMIVOLATILE ORGANIC ANALYSIS DATA

EPA SAMPLE NO.

LAB NAME: OAK RIDGE NATIONAL LAB CONTRACT: NR

ER218

LAB CODE: CASE NO: NR

MATRIX: (SOIL/WATER) WATER

SAMPLE WT/VOL: $\quad 100 \mathrm{ML}$

LEVEL: (LOW/MED) LOW

\% MOISTURE: NOT DEC.

DEC.

SAS NO: NR
SDG NO: $C 424$

LAB SAMPLE ID: $910307-154$

LAB FILE ID: >C3756

DATE RECEIVED 7-MAR-1991

DATE ANALYZED: 24-APR-1991

DATE EXTRACTED: 13-MAR-1991

DILUTION FACTOR:

10

\section{CONCENTRATION UNITS:} (UG/L OR UG/KG) UG/L

Q

\begin{tabular}{|c|}
\hline 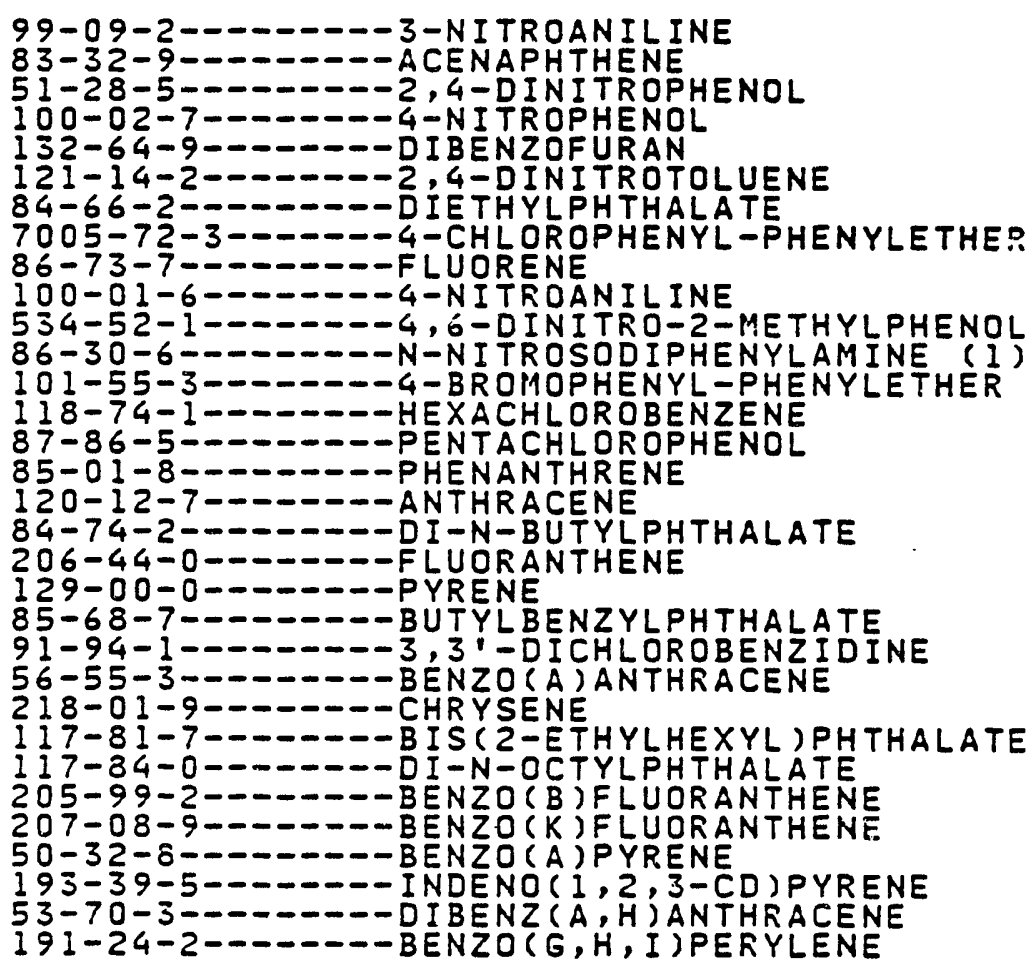 \\
\hline
\end{tabular}

\begin{tabular}{|c|c|}
\hline 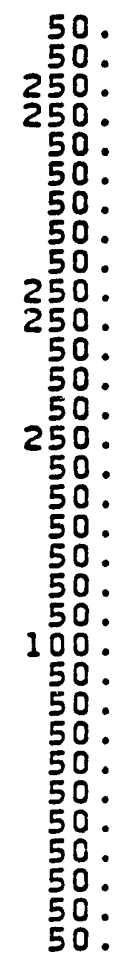 & 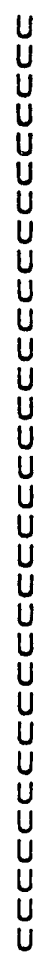 \\
\hline
\end{tabular}

REVIEWED BY:

DATE : 


\section{SEMIVOLATILE ORGANIC ANALYSIS DATA}

REQUEST NUMBER : OAL 94176

PROCEDURE NUMBER: 8240

MATRIX: SOIL \& WATER

EPA SAMPLE NO.

\section{SERIES :}

FREQUENCY :

CHARGE NUMBER: $\quad 33707380$

CUSTOMER NAME: SIEGRIST

LAB SAMPLE ID: 910307-154

SAMPLE WT/VOL: $100 \mathrm{ML}$

LAB FILE ID: >C3756

DATE SAMPLED:

DATE RECEIVED 7-MAR-1991 13:00

\% MOISTURE: NOT DEC.

DEC :

MATERIAL DESCRIPTION FUEL CONTAMINATION NUMBER TICS FOUND: 0

DATE ANALYZED: 24-APR-1991

DATE OF REPORT: 1-MAY- 91

CONCENTRATION UNITS: (UG/L OR UG/KG) UG/L

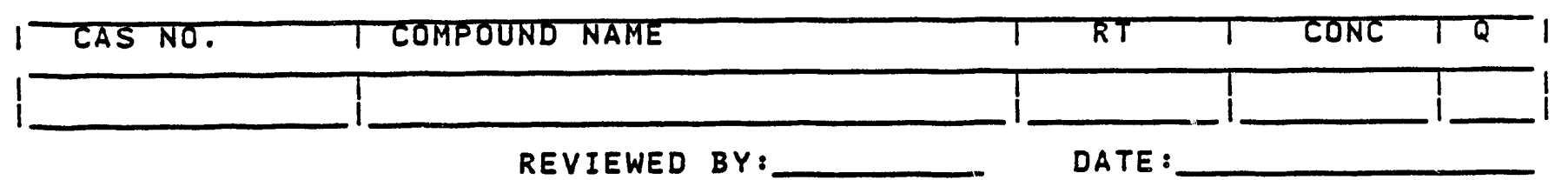


VOLATILE ORGANICS ANALYSIS DATA SHEET

LAB NAME: OAK RIDGE NATIONAL LAB CONTRACT:

LAB CODE: CASE NO: ORNL SAS NO:

MATRIX: (SOIL/WATER) WATER

SAMPLE WT/VOL: $5 \mathrm{ML}$

LEVEL: (LOW/MED) LOW

\% moisture : not dec.

COLUMN : (PACK/CAP) CAP
ER219

SDG NO: 0309

LAB SAMPLE ID: $910307-155$

LAB FILE ID: $\quad>01224$

DATE RECEIVED 7-MAR-1991

DATE ANALYZED: 9-MAR-1991

DILUTION FACTOR: $\quad 1.0$

CONCENTRATION UNITS:

CAS NO. COMPOUND (UG/L OR UG/KG) UG/L

$540-59-0-1$ -

74-87-3-1----CHLOROMETHANE

74-83-9------BROMOMETHANE

75-01-4------VINYL CHLOR IDE

75-00-3--.-- - CHLOROETHANE

75-09-2---

67-64-1--------ACETONE

75-15-0-- - - CARBON DISULF IDE

75-35-4--

$75-34-3-0-\cdots-1,1-D I C H L O R O E T H A N E$

$67-66-3-0-0$ CHLOROFORM

$107-06-2-\cdots-1,2-D I C H L O R O E T H A N E$

78-93-3--0---2-BUTANONE

$71-55-6-0-1,1,1-T R$ I CHLOROE THANE

56-23-5-

$108-05-4-\ldots---V I N Y L$ ACETATE

75-27-4-----BROMODICHLOROMETHANE

78-87-5------1,2-DICHLOROPROPANE

$10061-01-5----C I S-1,3-D I C H L O R O P R O P E N E$

79-0I-6------ TR I CHLOROE THENE

$124-48-1=-0-0$ IBROMOCHLOROMETHANE

79-00-5------1, I, 2-TR I CHLOROETHANE

$71-43-2--0-0-B E N Z E N E$

IOO61-02-06-DRANS-1, 3-DICHLOROPROPENE

75-25-2--

$108-10-1----4-11 E$ THYL-2-PENTANONE

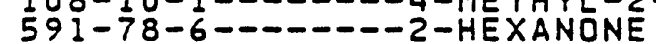

$127-18-4-----$ TETRACHLOROETHENE

$79-34-5-\cdots--1,1,2,2-T E T R A C H L O R O E T H A N E$

$108-88-3-\cdots---T O ́ L U E N E$

I 08-90-7------CHLOROBENZENE

$100-41-4--0---E T H Y L B E N Z E N E$

$100-42-5--\cdots---S T Y R E N E$

1330-20-7----XYYENE (TOTAL)

REVIEWED BY:

\begin{tabular}{|c|c|}
\hline $\begin{array}{r}10 . \\
100 \\
10 \\
10 \\
5.00 \\
100 \\
5.00 \\
5.00 \\
5.00 \\
5.00 \\
5.00 \\
100 \\
5.00 \\
5.00 \\
100 \\
5.00 \\
5.00 \\
5.00 \\
5.00 \\
5.00 \\
5.00 \\
5.00 \\
5.00 \\
100 \\
100 \\
5.00 \\
5.00 \\
12.00 \\
5.00 \\
5.00 \\
5.00 \\
5.00\end{array}$ & 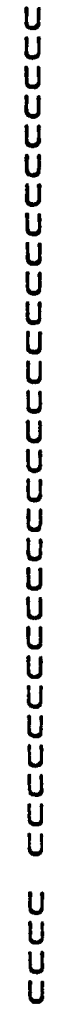 \\
\hline
\end{tabular}

DATE : 
SEMIVOLATILE ORGANIC ANALYSIS DATA

EPA SAMPLE NO.

LAB NAME: OAK RIDGE NATIONAL LAB CONTRACT: NR

ER219

LAB CODE: CASE NO: NR

SAS NO: NR SDG NO: $C 424$

RAATRIX: (SOIL/WATER) WATER

LAE SAMPLE ID: 910307-155

SAMPLE WT/VOL: $\quad 100 \mathrm{ML}$

LAB FILE ID: >C3757

LEVEL: (LOW/MED) LOW

DATE RECEIVED 7-MAR-1991

\% MOISTURE: NOT DEC.

DEC.

DATE ANALYZED: 24-APR-1991

EXTRACTION: (SEPF/CONT/SONC) SEPF

DATE EXTRACTED: 13-MAR-1991

GPC CLEANUP: $(Y / N) N$

$\mathrm{PH}: 6.58$

DILUTION FACTOR:

10

CAS NO.

COMPOUND

CONCENTRATION UNITS:

(UG/L OR UG/KG) UG/L

$Q$

\begin{tabular}{|c|c|c|}
\hline 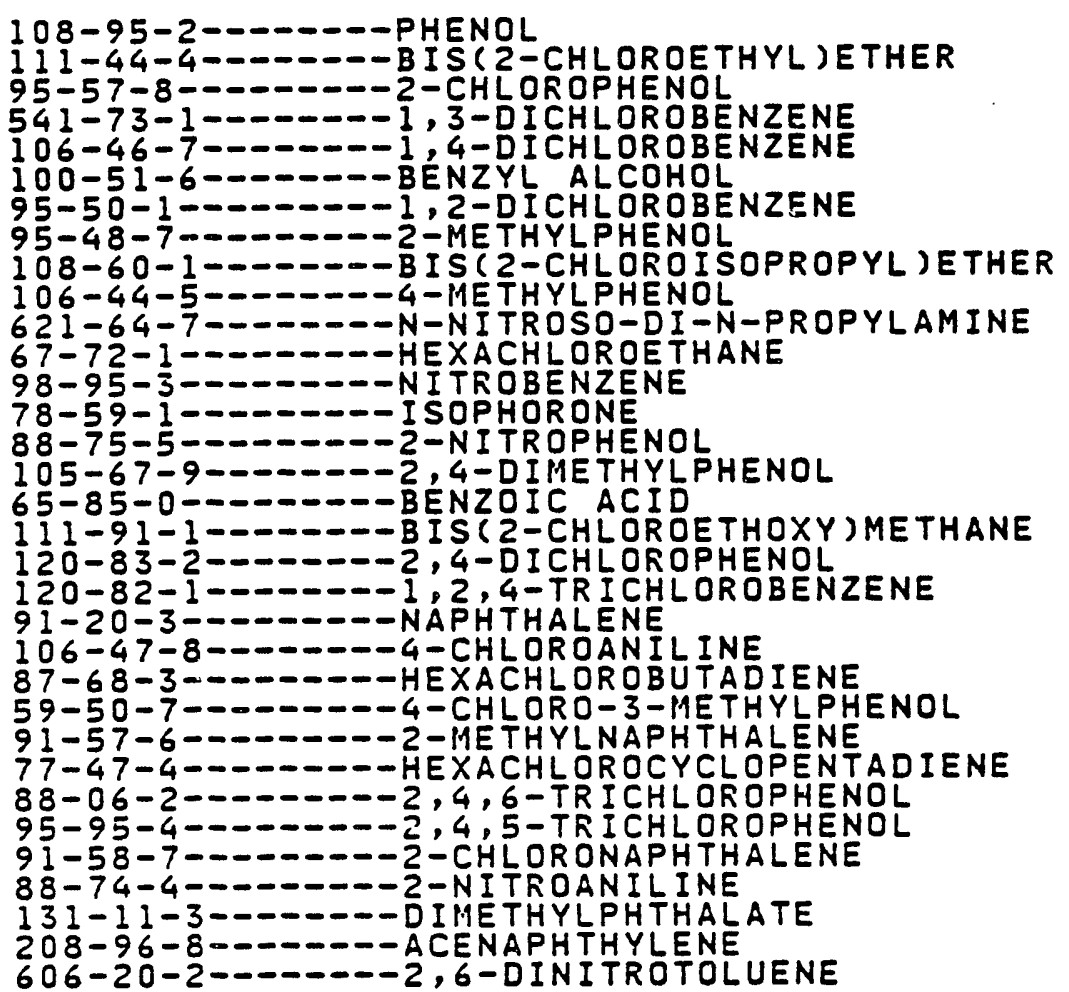 & 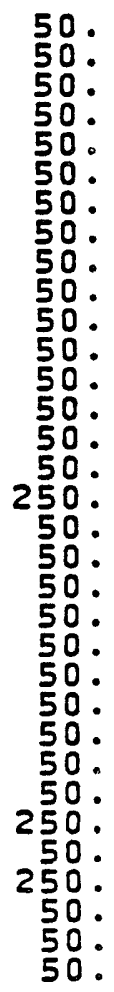 & 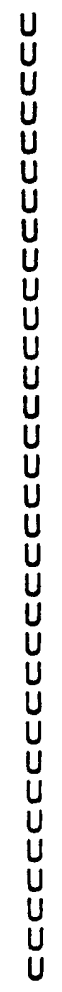 \\
\hline
\end{tabular}


SEMIVOLATILE ORGANIC ANALYSIS DATA

EPA SAMPLE NO.

LAB NAME: OAK RIDGE NATIONAL LAB CONTRACT: NR

ER219

LAB CODE: CASE NO: NR

SAS NO: NR

SDG NO: 0424

MATRIX: (SOIL/WATER) WATER

LAB SAMPLE ID: $910307-155$

SAMPLE WT/VOL: $\quad 100 \mathrm{ML}$

LAB FILE ID: >C3757

LEVEL: (LOW/MED) LOW

DATE RECEIVED 7-MAR-1991

\% moIsTURE: NOT DEC.

DEC.

DATE ANALYZED: 24-APR-1991

EXTRACTION: (SEPF/CONT/SONC) SEPF

DATE EXTRACTED: 13-MAR-1991

GPC CLEANUP: $(Y / N) N$

PH: 6.58

DILUTION FACTOR:

10

CAS NO.

COMPOUND

CONCENTRATION UNITS:

(UG/L OR UG/KG) UG/L

Q

\begin{tabular}{|c|c|c|}
\hline 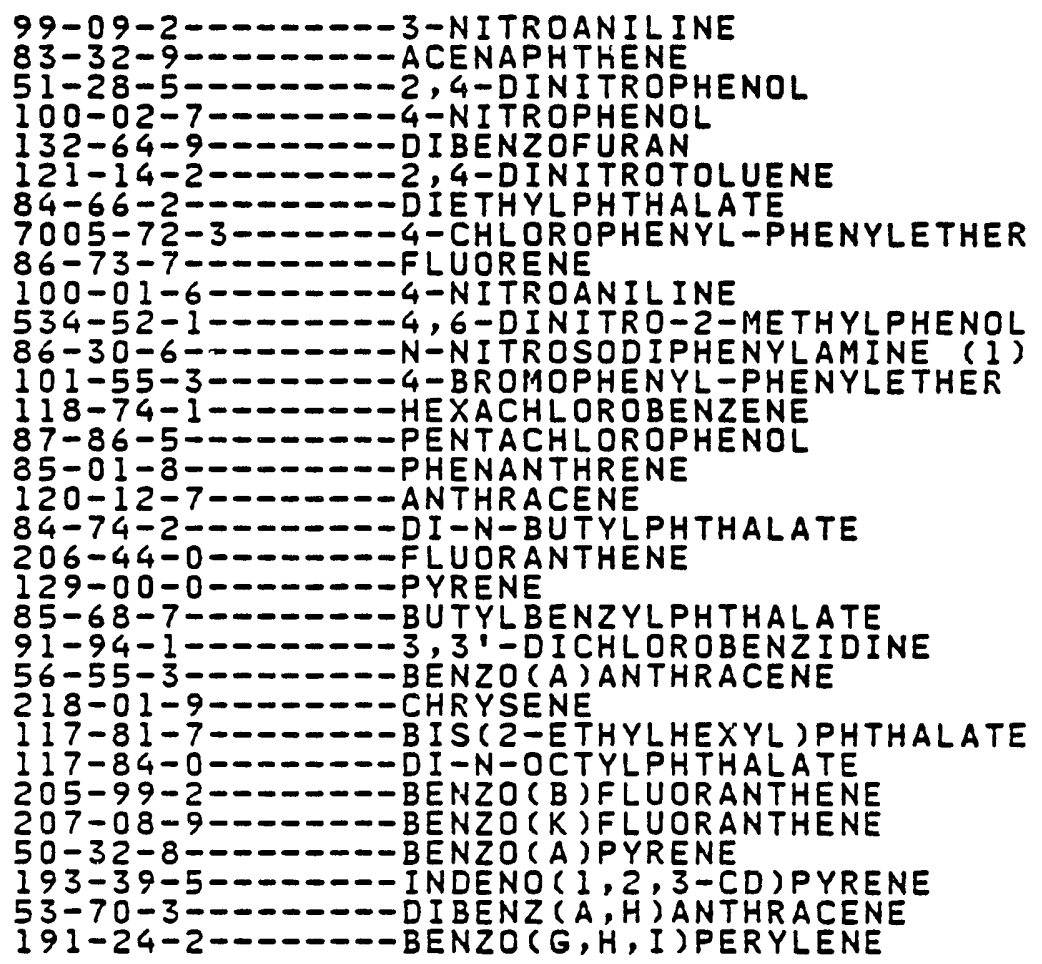 & 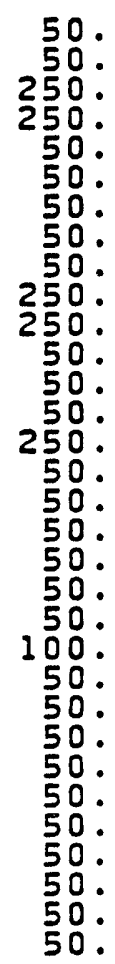 & 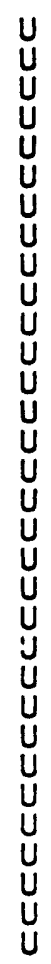 \\
\hline
\end{tabular}




\section{SEMIVOLATILE ORGANIC ANALYSIS DATA}

REQUEST NUMBER: OAL 94176

PROCEDURE NUMBER: 8240

MATRIX: SOIL \& WATER

EPA SAMPLE NO.

\section{SERIES: \\ FREQUENCY :}

CUSTOMER NAME: SIEGRIST

SAMPLE WT/VOL: $\quad 100 \mathrm{ML}$

DATE SAMPLED:

\% moisture: not dec.

DEC :

MATERIAL DESCRIPTION FUEL CONTAMINATION

NUMBER TICS FOUND: 0
ER219

CHARGE NUMBER: $\quad 33707380$

LAB SAMPLE ID: $910307-155$

LAB FILE ID: >C3757

DATE RECEIVED 7-MAR-1991 13:00

DATE ANALYZED: 24-APR-1991

DATE OF REPORT: 1-MAY-91

CONCENTRATION UNITS: (UG/L OR UG/KG) UG/L

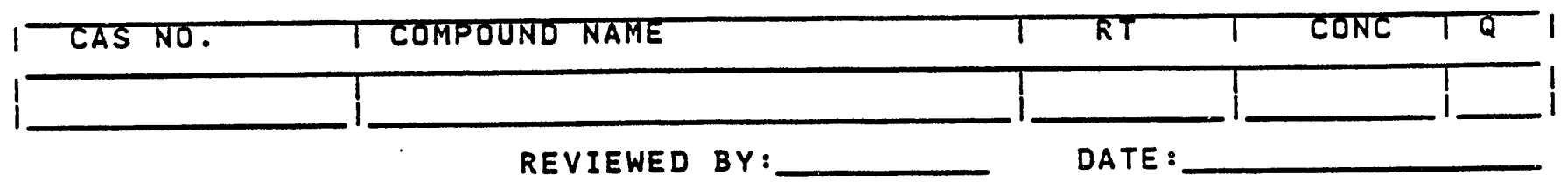


VOLATILE ORGANICS ANALYSIS DATA SHEET

EPA SAMPLE NO.

LAB NAME: OAK RIDGE NATIONAL LAB CONTRACT: NR

ER220

LAB CODE: CASE NO: ORNL

SAS NO: NR

SDG NO: 0309

MATRIX: (SOIL/WATER) WATER

LAB SAMPLE ID: $910307-156$

SAMPLE WT/VOL: $5 \mathrm{ML}$

LAB FILE ID: $>01225$

LEVEL: (LOW/MED) LOW

DATE RECEIVED 7-MAR-1991

\% MOISTURE: NOT DEC.

DATE ANALYZED: 9-MAR-1991

COLUMN : (PACK/CAP) CAP

DILUTION FACTOR: $\quad 1.0$

CAS NO. COMPOUND CONCENTRATION UNITS:

\begin{tabular}{|c|}
\hline 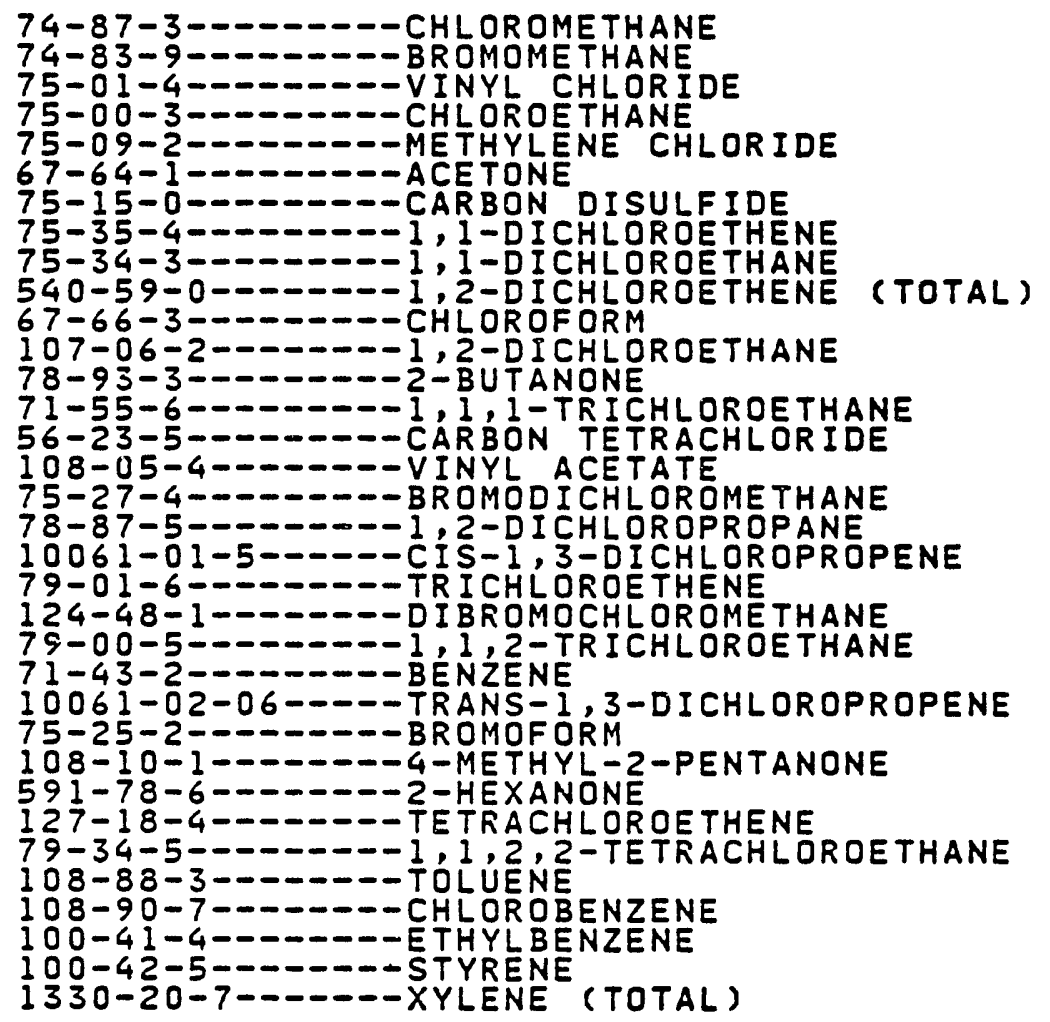 \\
\hline
\end{tabular}

REVIEWED BY:

Q

10.0

10.

10 .

5.00

io.

$5.00^{\circ}$

5.00

5.00

5.00

5.00

10.

5.00

5.00

10.

5.00

5.00

5.00

5.00

5.00

5.00

5.00

5.00

5.00

io.

10.

5.00

5.00

14.

7.00

5.00

5.00

5.00

DATE : 
SEMIVOLATILE ORGANIC ANALYSIS DATA

LAB NAME: OAK RIDGE NATIONAL LAB CONTRACT: NR
LAB CODE:
CASE NO: NR

MATRIX: (SOIL/WATER) WATER

SAMPLE WT/VOL: $\quad 100 \mathrm{ML}$

LEVEL: (LOW/MED) LOW

\% moisture: not dec. dec.

EXTRACTION: (SEPF/CONT/SONC) SEPF

GPC CLEANUP: (Y/N) N

PH: 6.36
SAS NO: NR

\section{ER220}

SDG NO: C424

LAB SAMPLE ID: $910307-156$

LAB FILE ID: >C3758

DATE RECEIVED 7-MAR-1991

DATE ANALYZED: 25-APR-1991

DATE EXTRACTED: 13-MAR-1991

DILUTION FACTOR: $\quad 10$

CONCENTRATION UNITS:

CAS NO.

COMPOUND

(UG/L OR UG/KG) UG/L

\begin{tabular}{|c|c|c|}
\hline 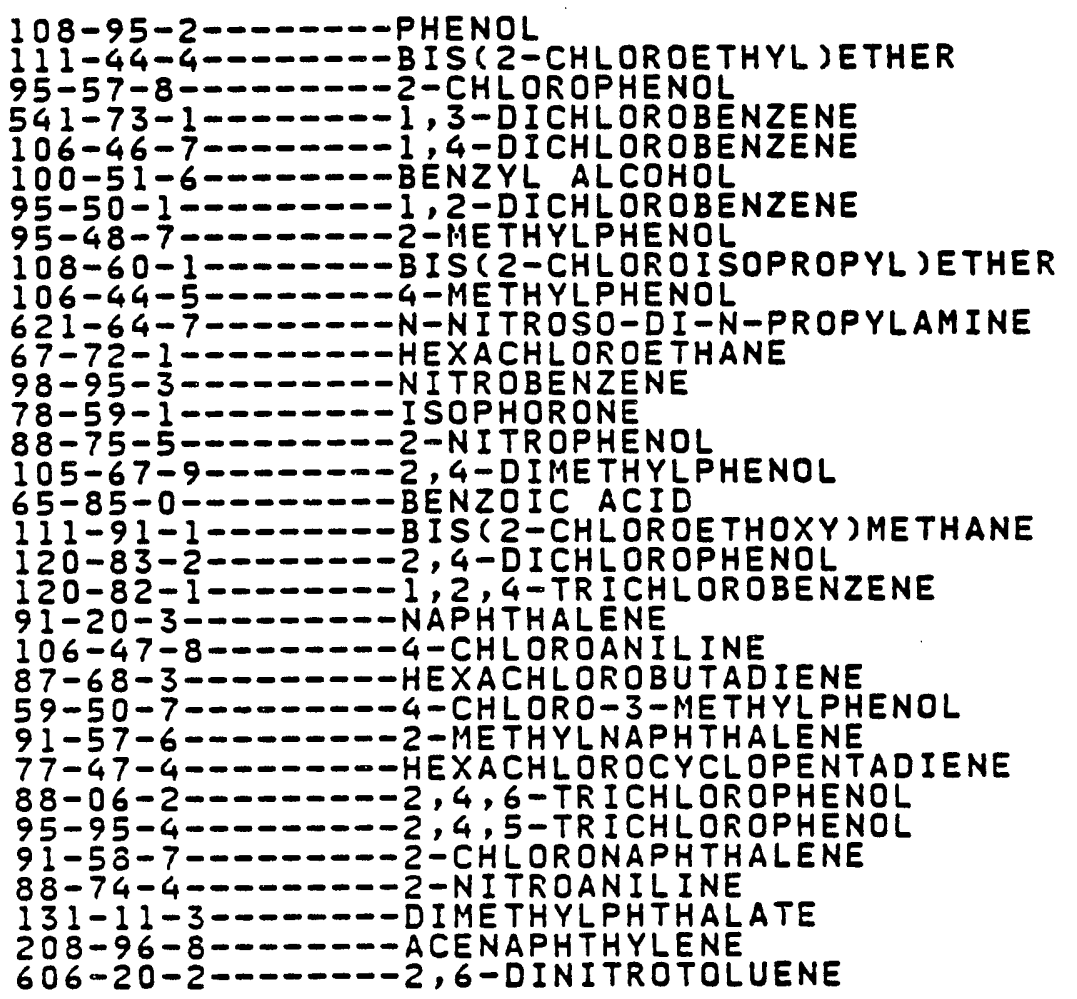 & 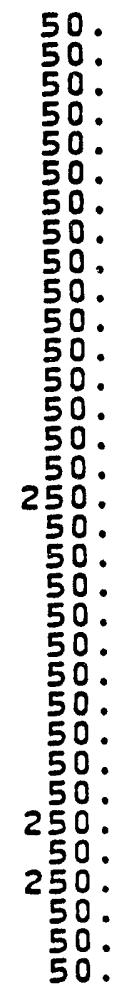 & 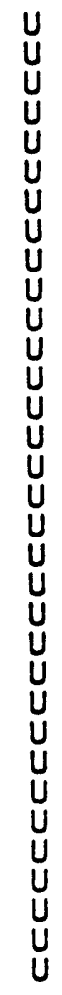 \\
\hline
\end{tabular}


SEMIVOLATILE ORGANIC ANALYSIS DATA

EPA SAMPLE NO.

LAB NAME: OAK RIDGE NATIONAL LAB CONTRACT: NR

LAB CODE: CASE NO: NR

MATRIX: (SOIL/WATER) WATER

SAMPLE WT/VOL: $\quad 100 \mathrm{ML}$

LEVEL: (LOW/MED) LOW

\% MOISTURE : NOT DEC.

DEC.

SAS NO: NR

LAB SAMPLE ID: $910307-156$

LAB FILE ID: >C3758

DATE RECEIVED 7-MAR-1991

EXTRACTION: (SEPF/CONT/SONC) SEPF

GPC CLEANUP: $(Y / N) N$

$\mathrm{PH}: 6.36$
DATE ANALYZED: 25-APR-1991

DATE EXTRACTED: 13-MAR-1991

DILUTION FACTOR:

10
COMPOUNE
CAS NO.

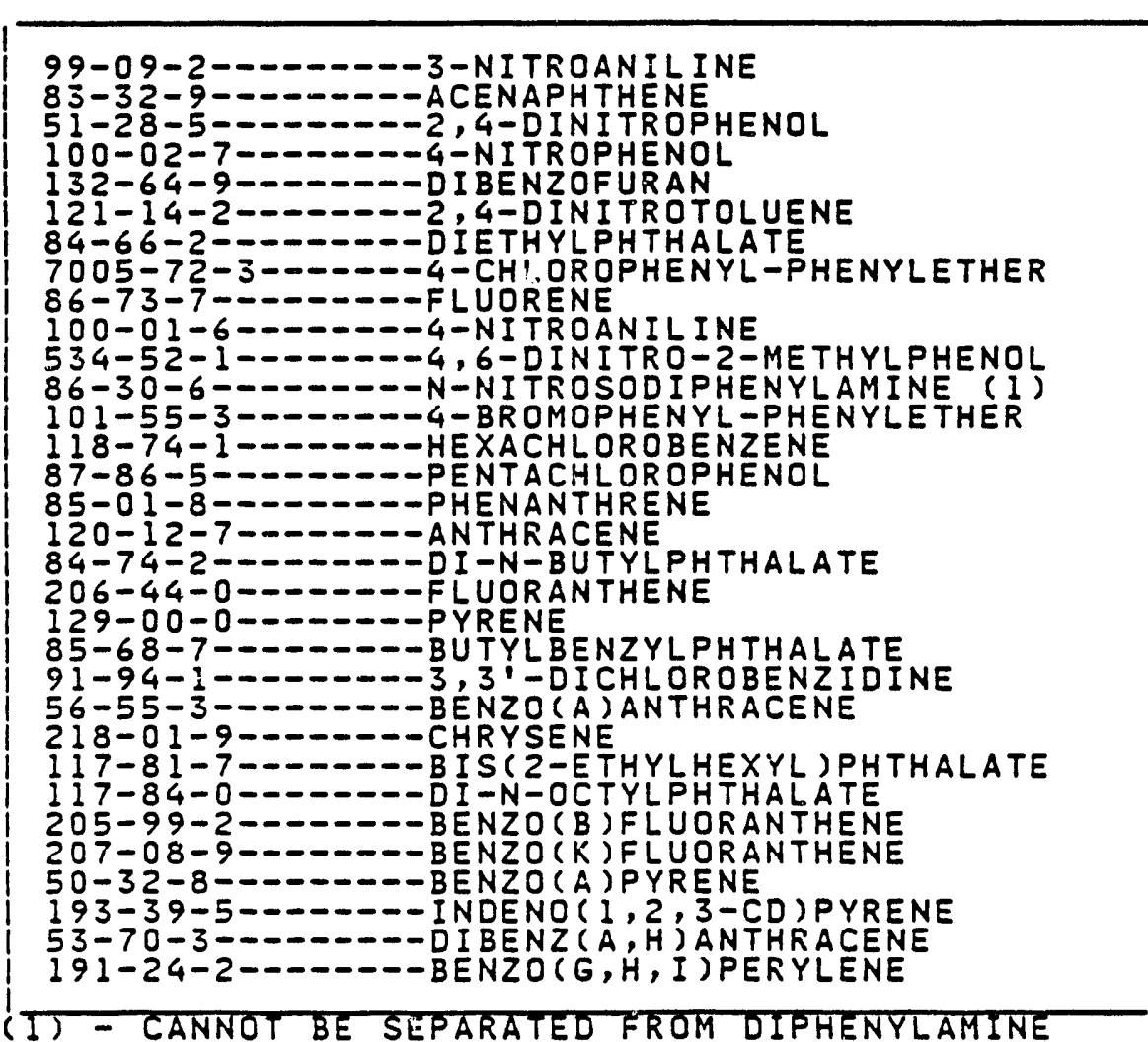

REVIEWED BY:
CONCENTRATION UNITS: (UG/L OR UG/KG) UG/L
Q

\begin{tabular}{|c|c|}
\hline 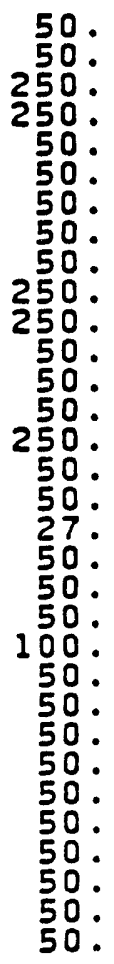 & 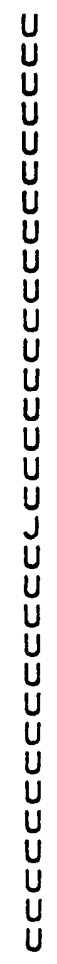 \\
\hline
\end{tabular}

DATE : 


\section{SEMIVOLATILE ORGANIC ANALYSIS DATA}

REQUEST NUMBER: OAL 94176

PROCEDURE NUMBER: 8240

MATRIX: SOIL \& WATER

EPA SAMPLE NO.

SERIES :

FREQUEMCY :

CUSTOMER NAME : SIEGRIST

SAMPLE WT/VOL: $\quad 100 \mathrm{ML}$

DATE SAMPLED:

\% moisture: not dec.

DEC :

MATERIAL DESCRIPTION FUEL CONTAMINATION

NUMBER TICS FOUND: 0
LAB SAMPLE ID: $910307-156$

LAB FILE ID: >C3758

DATE RECEIVED 7-MAR-1991 13:00

DATE ANALYZED: 25-APR-1991

DATE OF REPORT: 1-MAY-91

CONCENTRATION UNITS:

(UG/L OR UG/KG) UG/L

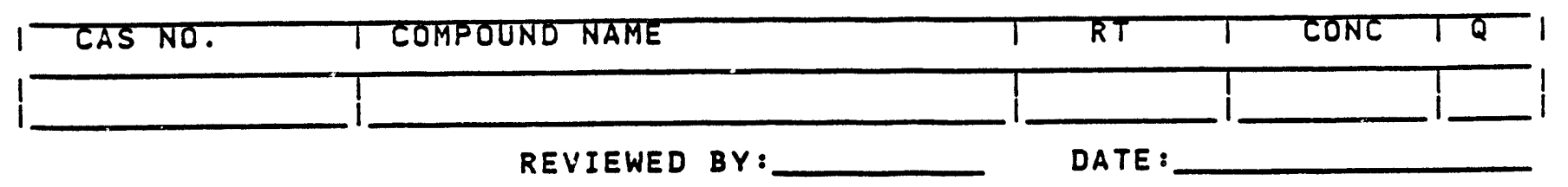


LAB NAME: OAK RIDGE NATIONAL LAB CONTRACT:

LAB CODE: CASE NO:

MATRIX: (SOIL/WATER) WATER

SAMPLE WT/VOL: $M L$

LEVEL : (LOW/MED)

\% MOISTURE: NOT DEC.

COLUMN: (PACK/CAP)
SAS NO:

\section{FBOI}

SDG NO:

LAB SAMPL: ID: $910307-157$

LAB FILE ID:

DATE RECEIVED 7-MAR-1991

DATE ANALYZED: 9-MAR-1991

DILUTION FACTOR: $\quad 1.0$

CAS NO.

COMPOUND

CONCENTRATION UNITS:

(UG/L OR UG/KG) UG/L

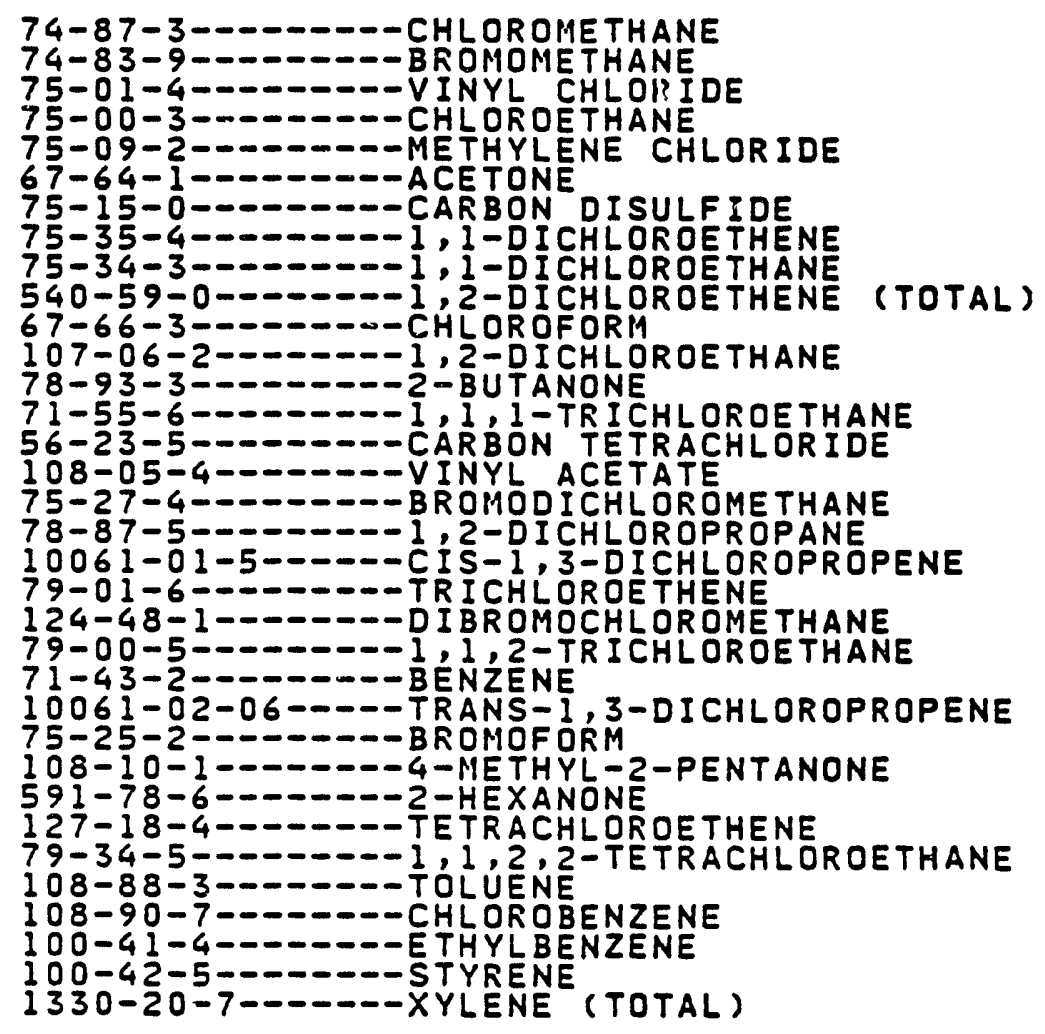

$540-59-0-\cdots--1,2-D I C H L O R O E T H E N E$ (TOTAL)

\begin{tabular}{|c|}
\hline 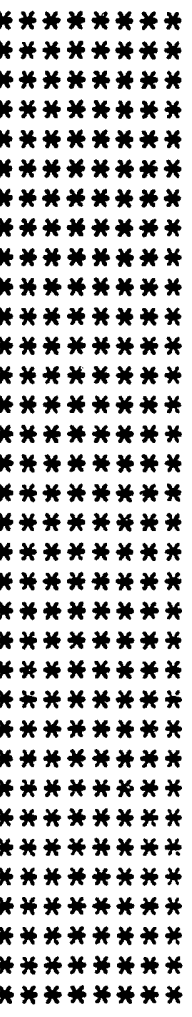 \\
\hline
\end{tabular}

Q

REVIEWED BY:

DATE :

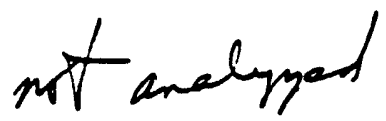


SEMIVOLATILE ORGANIC ANALYSIS DATA

LAB NAME: OAK RIDGE NATIONAL LAB CONTRACT: NR

LAB CODE: CASE NO: NR

MATRIX: (SOIL/WATER) WATER

SAMPLE WT/VOL: $\quad 100 \mathrm{ML}$

LEVEL: (LOW/MED) LOW

\% MOISTURE: NOT DEC. DEC.

EXTRACTION: (SEPF/CONT/SONC) SEPF

GPC CLEANUP: $(Y / N) N$

$\mathrm{PH}: 6.43$
SAS NO: NR
FBO1

SDG NO: $C 424$

LAB SAMPLE ID: 910307-157

LAB FILE ID: >C3759

DATE RECEIVED 7-MAR-1991

DATE ANALYZED: 25-APR-1991

DATE EXTRACTED: 13-MAR-1991

DILUTION FACTOR: 10

CONCENTRATION UNITS:

CAS NO.

COMPOUND

(UG/L OR UG/KG) UG/L

$Q$

$108-95-2-0----P H E N O L$

I I -44-4------BI S ( 2-CHLOROETHYL) ETHER

$95-57-8------2-C H L O R O P H E N O L$

$541-73-1-\ldots-1,3-D I C H L O R O B E N Z E N E$

$106-46-7-\ldots-\infty-1,4-D I C H L O R O B E N Z E N E$

$100-51-6-----B E N Z Y L$ ALCOHOL

$95-50-1--\cdots-1,2-D I C H L O R O B E N Z E N E$

95-48-7---.---2-METHYLPHENOL

$108-60-1 \cdots--1$ I S (2-CHLORO I SOPROPYL)ETHER

$106-44-5-----4-M E T H Y L P H E N O L$

$621-64-7-\infty--N-N I T R O S O-D I-N-P R O P Y L A M I N E$

$67-72-1-\ldots-\ldots$ HEXACHLOROETHANE

$98-95-3-0-----N I T R O B E N Z E N E$

78-59-1--------ISOPHORONE

$88-75-5-\cdots-2-N I T R O P H E N O L$

$105-67-9--0-2,4-D I M E T H Y L P H E N O L$

65-85-0-------BENZOIC ACID

$111-91-1-0 .-0$ IS (2-CHLOROETHOXY) METHANE

$120-83-2------2,4-D I C H L O R O P H E N O L$

$120-82-1-\ldots-\infty-1,2,4-T R$ I CHLOROBENZENE

$91-20-3-\cdots---N A P H T H A L E N E$

$106-47-8-\cdots--4-C H L O R O A N I L I N E$

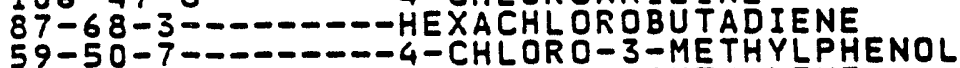

$91-57-6-\infty-\infty-2-M E$ THYLNAPHTHALENE

$77-47-4-1-0-1 E X A C H L O R O C Y C L O P E N T A D I E N E$

$88-06-2-\cdots--2,4,6-$ TR I CHLOROPHENOL

$95-95-4--\ldots---2,4,5-T R$ I CHLOROPHENCL

$91-53-7-\ldots-\infty-2-C H L O R O N A P H T H A L E N E$

$88-74-4-----2-N I T R O A N I L I N E$

$131-11-3-\infty-\infty D$ IMETHYLPHTHALATE

208-96-8------ACENAPH THYLENE

$606-20-2-\cdots--2,6-D I N$ I TROTOLUENE

\begin{tabular}{|c|c|}
\hline 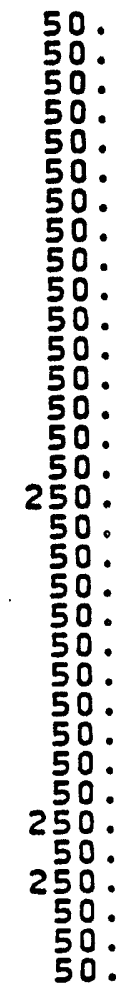 & 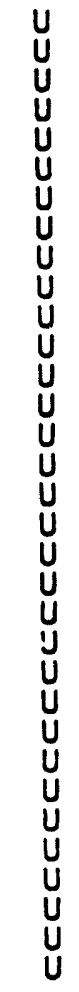 \\
\hline
\end{tabular}


SEMIVOLATILE ORGANIC ANALYSIS DATA

EPA SAMPLE NO.

LAB NAME: OAK RIDGE NATIONAL LAB CONTRACT: NR

FBOI
LAB CODE:
CASE NO: NR

SAS NO: NR

SDG NO: 6424

MATRIX: (SOIL/WATER) WATER

SAMPLE WT/VOL: $100 \mathrm{ML}$

LEVEL: (LOW/MED) LOW

\% MOISTURE: NOT DEC.

DEC.

EXTRACTION: (SEPF/CONT/SONC) SEPF

GPC CLEANUP: $(Y / N) N$

PH: 6.43
LAB SAMPLE ID: 910307-157

LAB FILE ID: >C3759

DATE RECEIVED 7-MAR-1991

DATE ANALYZED: 25-APR-1991

DATE EXTRACTED: 13-MAR-1991

DILUTION FACTOR:

10
CAS NO. COMPOUND
CONCENTRATION UNITS: (UG/L OR UG/KG) UG/L
Q

\begin{tabular}{|c|c|c|}
\hline 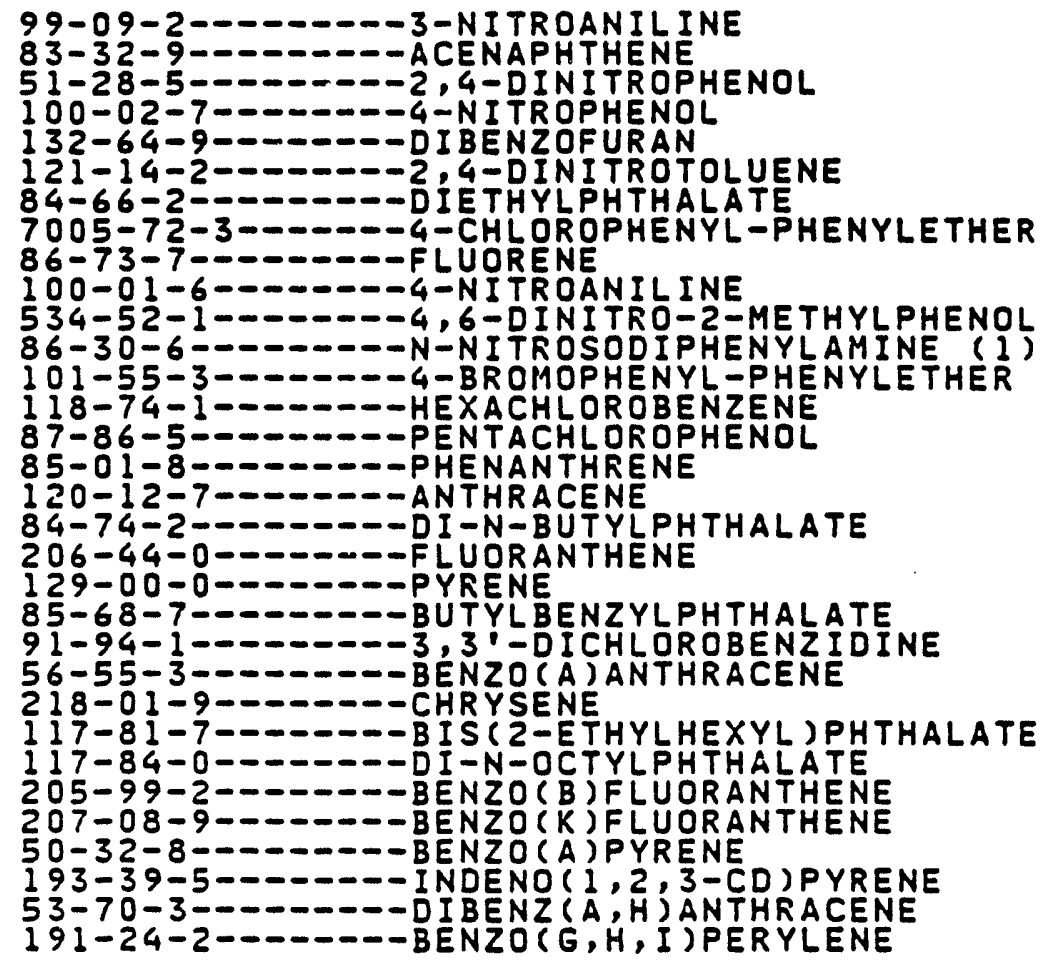 & 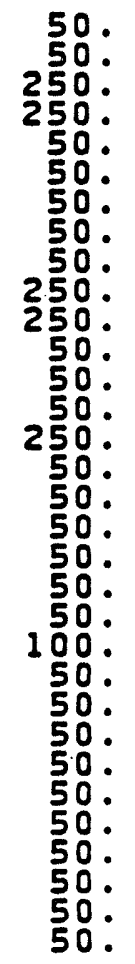 & 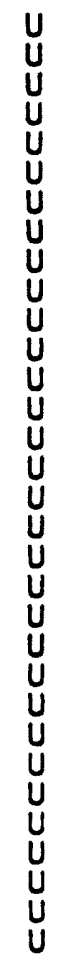 \\
\hline
\end{tabular}


Lab Name: Oak Ridge National Lab

Lab Code:

Case nO: ORNL

Matrix: (soll/water) soIL

Sample wt/vol: 5 G

Level: (low/med) Low

\% Moisture, not dec.

Column, (pack/cap) CAP
Contract: NR

SAS NO: NR

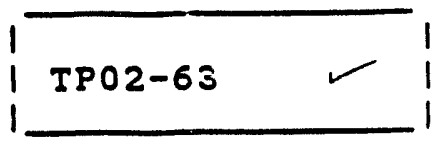

TP02-63

SDG NO: 0308
Lab Sample ID: $910307-158$

Lab File ID: $>01203$

Date Received 7-Mar-1991

Date Analyzed: 8-Mar-1991

Dilution Factor: $\quad 1.0$

CAS NO.

COMPOUND

CONCENTRATION UNITS :

(UG/L Or UG/KG) UG/KG

Q

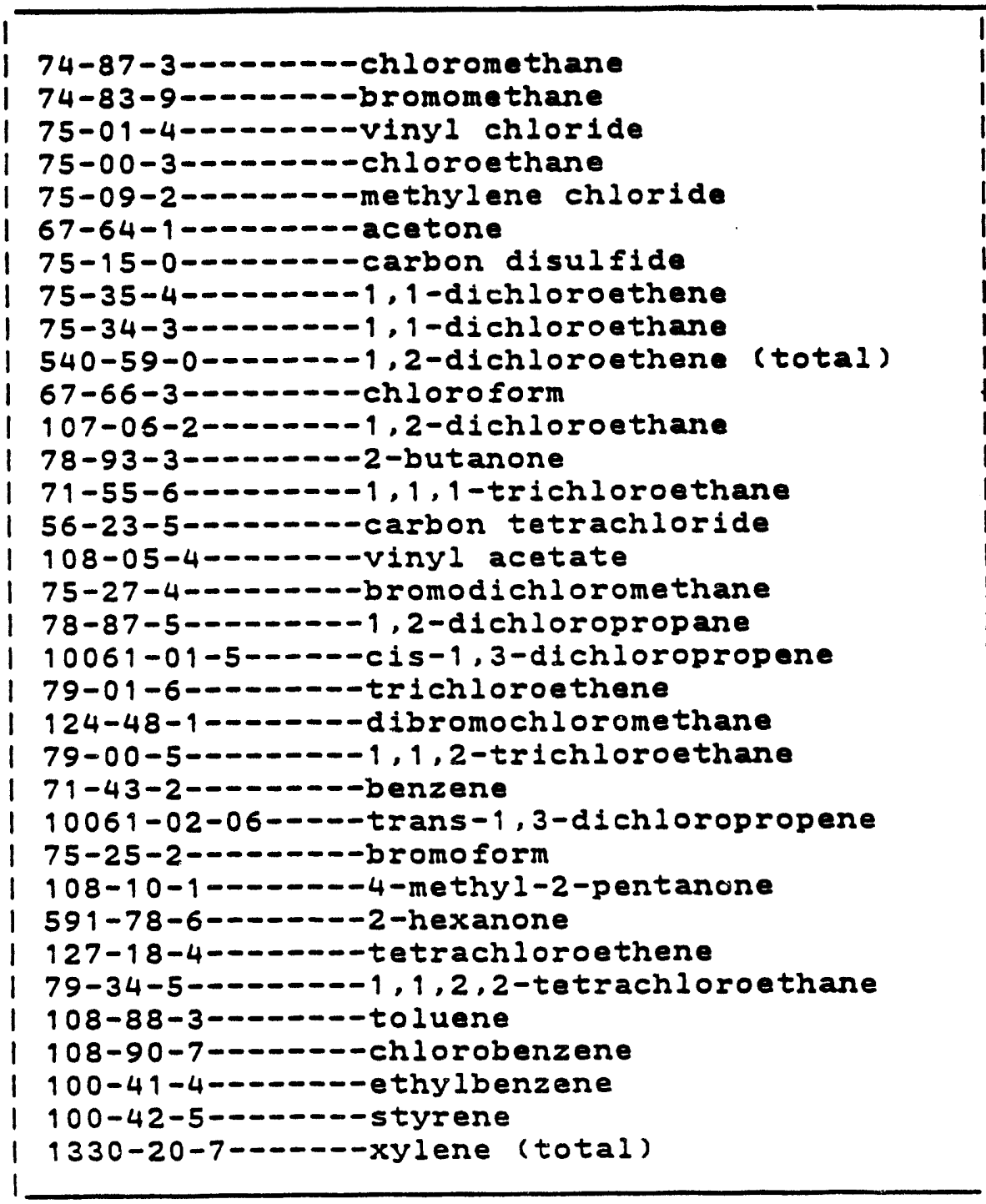

Reviewed by: zelpor

Date:

10.

10.

10 .

10.

5.00

10.

5.00

5.00

5.00

5.00

5.00

5.00

10.

5.00

5.00

10.

5.00

5.00

5.00

5.00

5.00

5.00

5.00

5.00

5.00

10.

10.

5.00

5.00

5.00

5.00

5.00

5.00

5.00

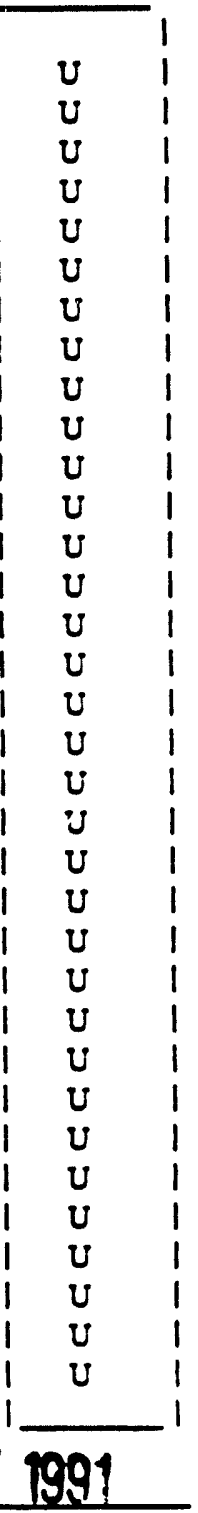


Semivolatile Organic Analysis Data

EPA SAMPLE NO.

Lab Name: Oak Ridge National Lab Contract: NR

TP02-63

Lab Code: Case no: ORNL

SAS NO: NR

SDG NO: C423-2

Matrix: (soil/water) soIl

Lab Sample ID: $910307-158$

Sample wt/vol: $29.8 \mathrm{G}$

Lab File ID: $\quad>C 3740$

Level: (lowined) LOW

Date Received 7-Mar-1991

\% Moisture: not dec.

dec.

Date Analyzed: 24-Apr-1991

Extraction: (Sepf/Cont/Sone) SONC

Date Extracted: 12-Mar-1991

GPC CI RUP: $(Y / N)$ N

$\mathrm{pH}: \quad \mathrm{NR}$

Dilution Factor:

1

CAS NO.

COMPOUND

CONCENTRATION UNITS:

(UG/L Or UG/KG) UG/KG

Q

$108-95-2-------p h e n o l$

$111-44-4--\cdots---b$ is $(2-c h l o r o e t h y l)$ ether

95-57-8--------2-chlorophenol

I 541-73-1-------1,3-dichlorobenzene

1 106-46-7-------9,4-dichlorobenzene

1 100-51-6-.-.---benzyl alcohol

1 95-50-1-.---.--1,2-dichlorobenzene

1 95-48-7--------2-methylphenol

1 108-60-i-n----bis(2-chloroisopropyl)ether

I 106-44-5-------4-methylphenol

| 621-64-7--..--n-nitroso-di-n-propylamine

1 67-72-1-...-.--hexachloroethane

1 98-95-3--------nitrobenzere

1 78-59-1--------isophorone

1 88-75-5--------2-nitrophenol

1 105-67-9-------2,4-dimethylphenol

1 65-85-0-------benzoic acid

I 111-91-1------bis (2-chloroethoxy) methane

1 120-83-2-------2,4-dichlorophenol

1 120-82-1-.----1,2,4-trichlorobenzene

1 91-20-3-..-.--naphthalene

1 106-47-8-------4-chloroaniline

1 87-68-3-------hexachlorobutadiene

I 59-50-7--..---4-chloro-3-methylphenol

I 91-57-6--------2-methylnaphthalene

1 77-47-4-..----hexachlorocyclopentadiene

I 88-06-2--------2,4,6-trichlorophenol

I 95-95-4--------2,4,5-trichlorophenol

1 91-58-7--.---.--2-chloronaphthalene

I 88-74-4--.---n-nitroaniline

1 131-11-3-------dimethylphthalate

1 208-96-8-------acenaphthylene

1 606-20-2-0.---2,6-dinitrotoluene 
Semivolatile Organic Analysis Data

Lab Name: Oak Ridge National Lab Contract: NR
EPA SAMPZE NO.

Lab Code: case no: ORNL SAS NO: NR

SDG NO: C423-2

Matrix: (soil/water) soIL

Lab Sample ID: 910307-158

Sample wt/vol: $\quad 29.8 \mathrm{G}$

Lab File ID: >C3740

Level: (low/med) Low

Date Received 7-Mar-1991

\% Moisture: not dec. dec.

Date Analyzed: 24-Apr-1991

Extraction: (Sepf/Cont/Sonc) SONC

Date Extracted: 12-Mar-1991

GPC Cleasup: $(Y / N) N \quad$ pH: NR

Dilution Factor: 1

CONCENTRATION UNITS:

CAS NO. COMPOUND (UG/L OY UG/KG) UG/KG

Q

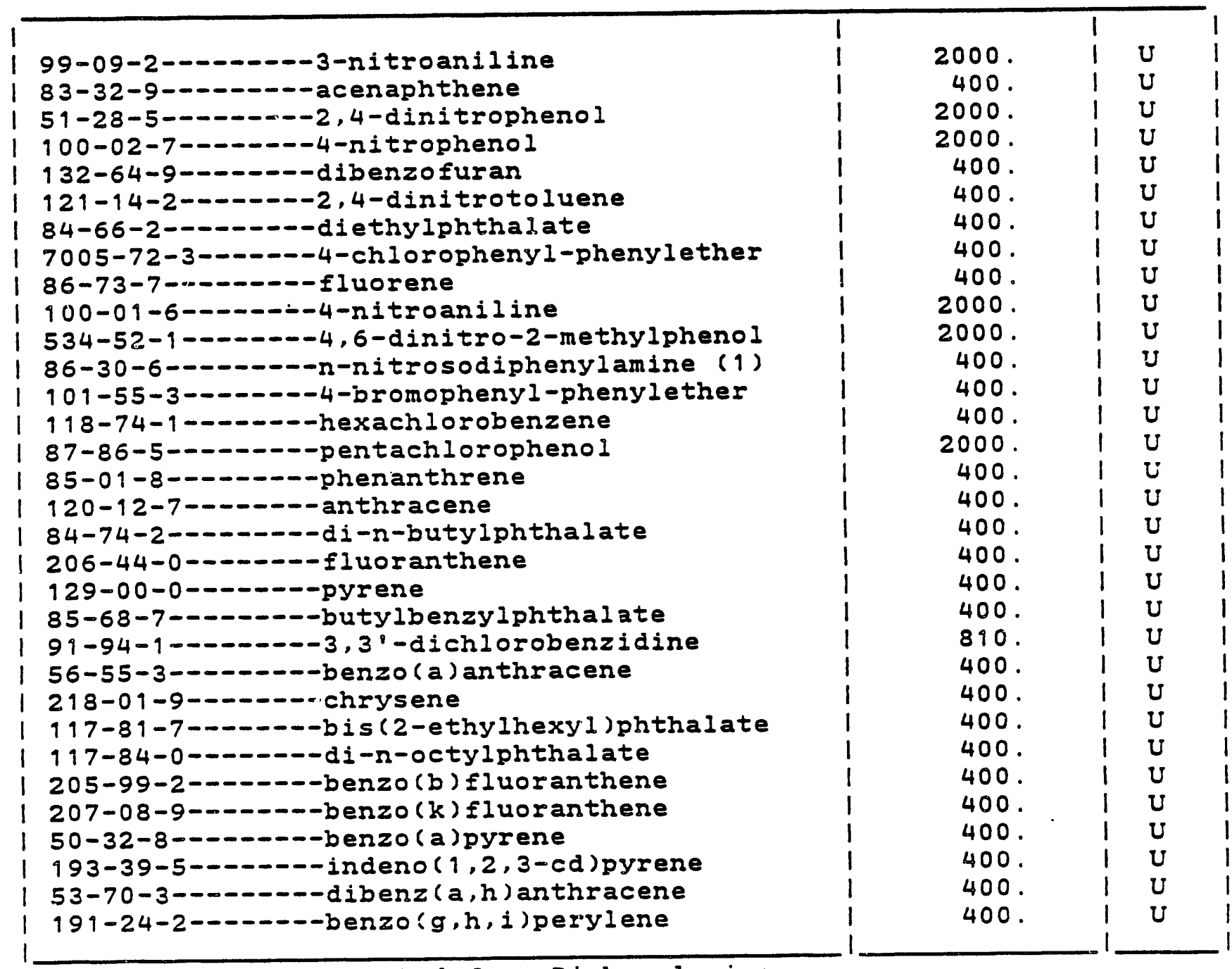

(1) - Cannot be separated from Diphenylamine

Reviewed by:

Date : 


\section{Semivolatile organic Analysis Data}

Request Number: OAL 94177

Procedure Number: 8240

Series:

Frequency:

Customer Name: SIEGRIST

Sample wt/vol: $\quad 29.8 \mathrm{G}$

Date Sampled:

\% Moisture: not dec.

dec:

Material Description FUEL CONTAMINATION

Number IICs found: 0
EPA SAMPLE NO.

TP02-63

Matrix: SOIL AND WATER

Charge Number: $\quad 33707380$

Lab Sample ID: 910307-158

Lab File ID: $\quad>C 3740$

Date Received 7-Mar-1991 13:00

Date Analyzed: 24-Apr-1991

Date of Report: 16-MAY-91

CONCENTRATION UNITS:

(UG/L OI UG/KG) UG/KG

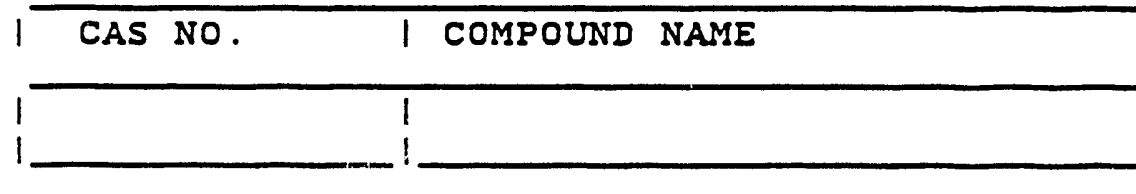

Reviewed by:

\begin{tabular}{ll|lll|}
\hline RT & I CONC
\end{tabular}

$\begin{array}{lll}1 & 1 & 1 \\ 1 & 1\end{array}$

Date : 
Lab Name: Oak Ridge National Lab Lab Code: Case no: ORNL

Matrix: (soil/water) SOIL

Sample wt/vol: 5 G

Level: (low/med) LOW

\% Moisture: not dec.

Column: (pack/cap) CAP
Centract: NR

SAS NO: NR
TP02-63MS

SDG NO: 0308
Lab Sample ID: 910307-159

Lab File ID: $\quad>01204$

Date Received 7-Mar-1991

Date Analyzed: 8-Mar-1991

Dilution Factor: $\quad 1.0$

CAS NO.

COMPOUND

CONCENTRATION UNITS: (UG/L Or UG/KG) UG/KG

74-87-3--.---chloromethane

| 74-83-9--.-----bromomethane

1 75-01-4--------vinyl chloride

1 75-00-3-0.----chloroethane

1 75-09-2-.-.----methylene chloride

| 67-64-1--------acetone

1 75-15-0--------carbon disulfide

1 75-35-4-------1, 1-dichloroethene

1 75-34-3--.-----1,1-dichloroethane

I 540-59-0-.-.--1,2-dichloroethene (total)

I 67-66-3--.----chloroform

1 107-06-2-------1,2-dichloroethane

1 78-93-3--------2-butanone

1 71-55-6-.---1,1,1-trichloroethane

1 56-23-5-.-...---carbon tetrachloride

| 108-05-4--------vinyl acetate

1 75-27-4--------bromodichloromethane

| 78-87-5--------1,2-dichloropropane

| 10061-01-5------cis-1,3-dichloropropene

1 79-01-6--------trichloroethene

I 124-48-1--.----dibromochloromethane

1 79-00-5--...-1, 1,2-trichloroethane

1 71-43-2--------benzene

1 10061-02-06----trans-1,3-dichloropropene

I 75-25-2--------bromoform

1 108-10-1------4-methyl-2-pentanone

| 591-78-6-------2-hexanone

127-18-4--.----tetrachloroethene

19-34-5--.----1, 1,2,2-tetrachloroethane

1 108-88-3-------toluene

1 108-90-7------chlorobenzene

100-41-4-------ethylbenzene

100-42-5--------styrene

(1330-20-7--.---xylene (total)

Reviewed by:

10.

10 .

10 .

90 .

5.00

10 .

5.00

5.00

5.00

5.00

5.00

5.00

90.

5.00

5.00

10.

5.00

5.00

5.00

5.00

5.00

5.00

5.00

5.00

5.00

10.

10.

5.00

5.00

5.00

5.00

5.00

5.00

5.00

Date: 


\section{Semivolatile Organic Analysis Data}

EPA SAMPLE NO.

Lab Name: Oak Ridge National Lab Contract: NR

TP02-63MS

Lab Code:

Case nO: ORNL

SAS NO: NR

SDG NO: $C 423-2$

Matrix: (soil/water) soIL

Lab Sample ID: 910307-159

Sample wt/vol: $\quad 29.9$ G

Lab File ID: $\quad>C 3735$

Level: (low/med) LoW

Date Received 7-Mar-1991

\% Moisture: not dec.

dec.

Date Analyzed: 23-Apr-1991

Extraction: (Sepf/Cont/Sonc) SONC

Date Extracted: 12-Mar-1991

GPC Cleanup: $(Y / N) N$

PH: $\quad$ NR

Dilution Factor:

1.0

CAS NO.

COMPOUND

CONCENTRATION UNITS:

(UG/L or UG/KG) UG/KG

$\dot{Q}$

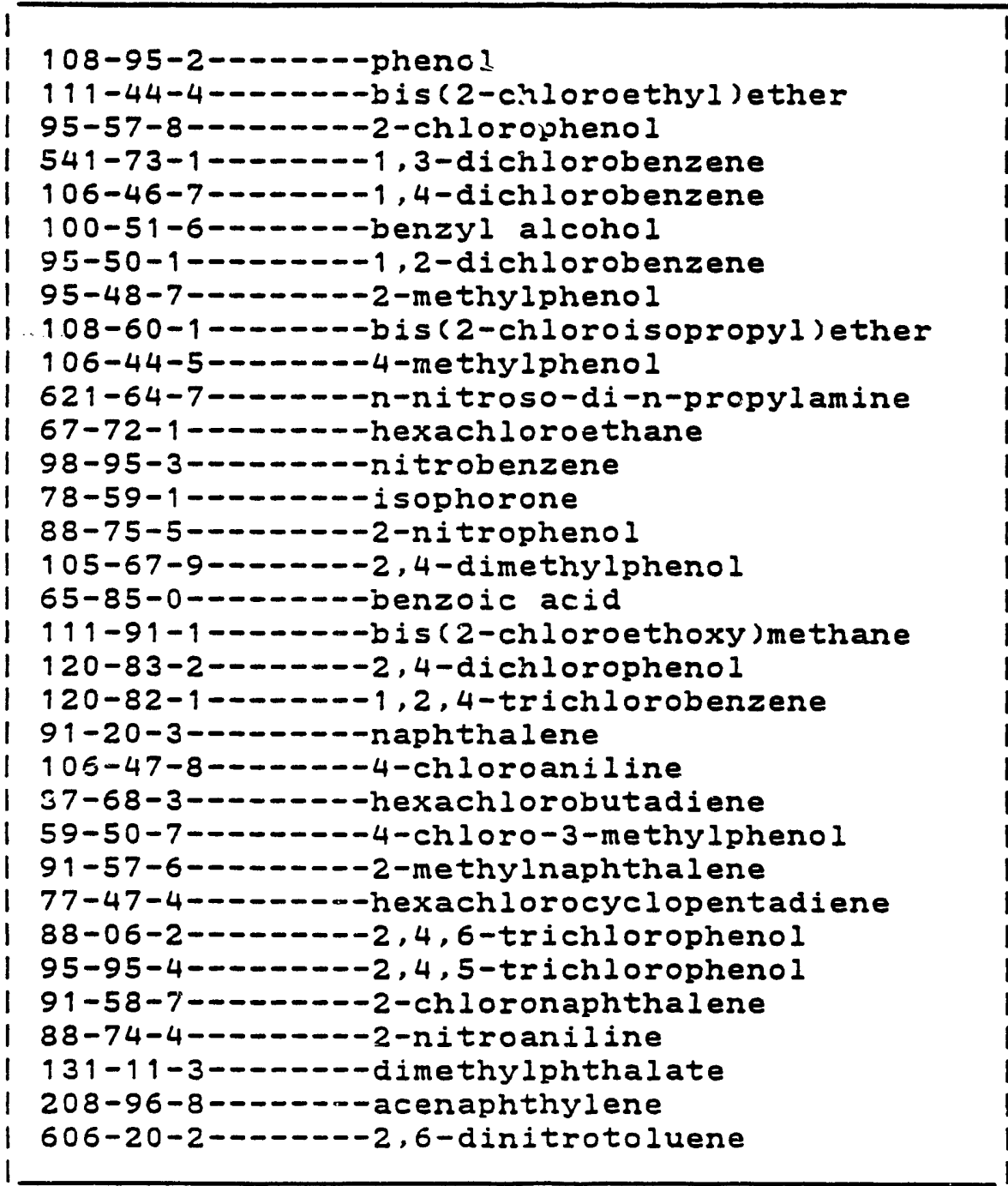

1800 .

410 .

1700 .

410 .

570.

410.

490.

410.

410.

410 .

1300 .

410.

410.

410 .

410.

490.

2100 .

410.

490.

1000 .

410 .

410.

410.

2400 .

410 .

410.

410.

2100 .

410.

2100.

410.

410 .

410 .

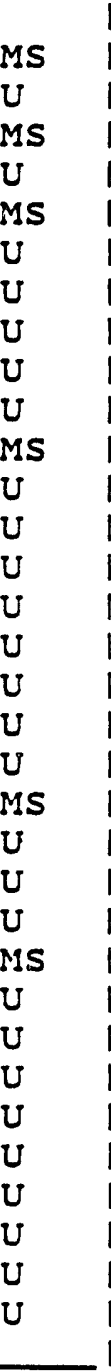


Semivolatile Organic Analysis Data

EPA SAMPLE NO.

Lab Name: Oak Ridge National Lab
Contract: NR

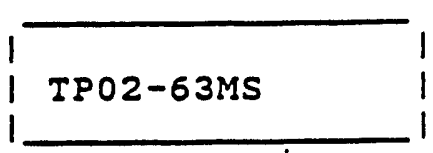
Lab Code:
Case no: ORNL
SAS NO: NR
SDG NO: C423-2

Matrix: (soil/water) soIL

Sample wt/vol: $\quad 29.9 \mathrm{G}$

Level: ( low/med) Low

\% Moisture: not dec. dec.

Extraction: (Sepf/Cont/Sonc) SoNC
PH : NR
Lab Sampie ID: 910307-159

Lab File ID: >C3735

Date Received 7-Mar-1991

Date Analyzed: 23-Apr-1991

Date Extracted: 12-Mar-1991
GPC Cleanup: $(Y / N) N$

CAS NO.
COMPOUND
Dilution Factor:

1.0
CONCENTRATION UNITS: (UG/L Or UG/KG) UG/KG

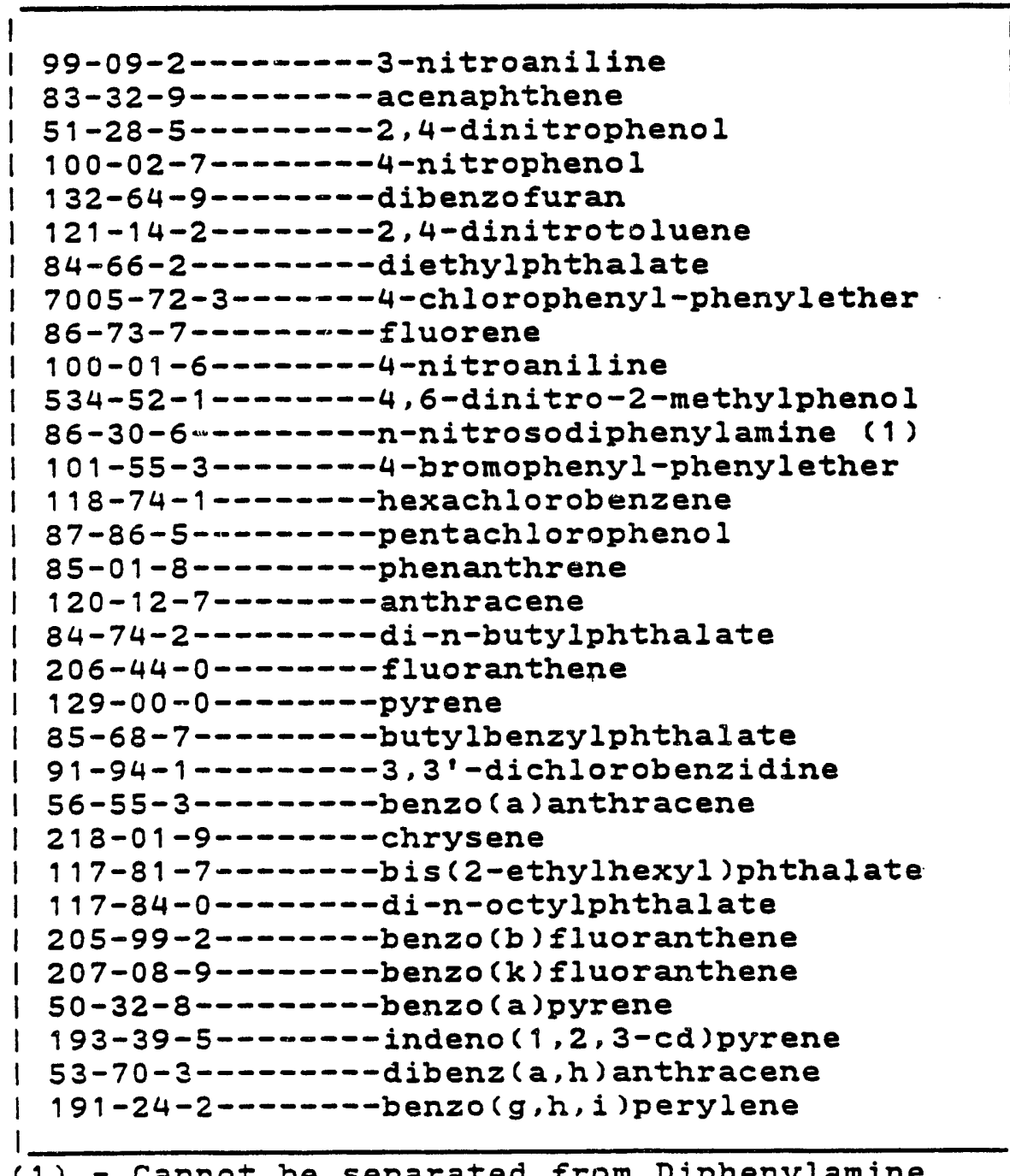

(1) - Cannot be separated from Diphenylamine

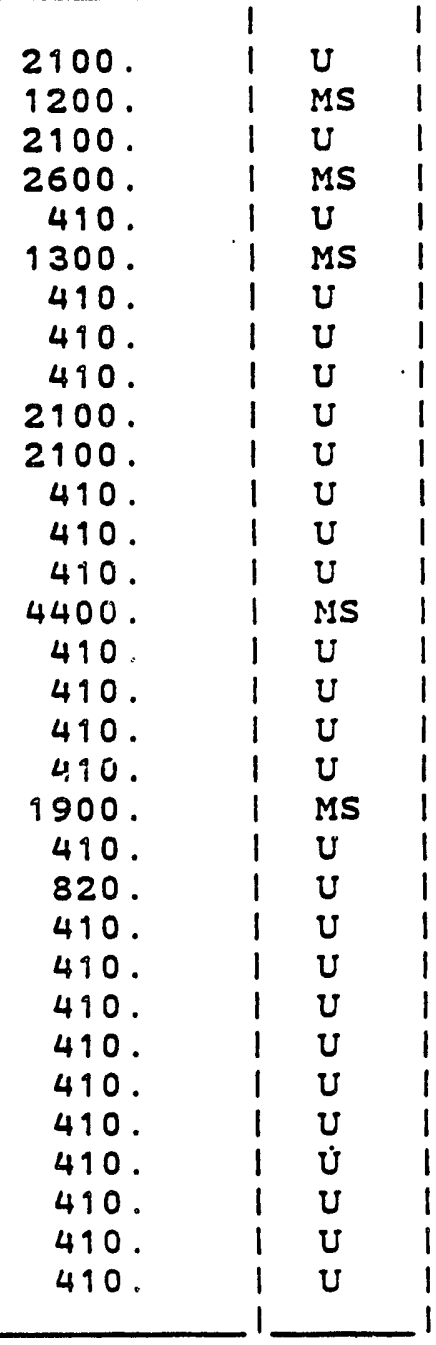

Date : 
Lab Name: Oak Ridge National Lab

Lab Code:

Case no: ORNL

Matrix: (soil/water) SOIL

Sample wt/vol:

5 G

Level: (low/med) Low

\% Moisture: not dec.

Column: (pack/cap) CAP
Contract: NR

SAS NO: NR

SDG NO: 0308

Lab Sample ID: 910307-160

Lab File ID: $\quad>01205$

Date Received 7-Mar-1991.

Date Analyzed: 8-Mar-1991

Dilution Factor: $\quad 1.0$

CAS NO.

COMPOUND

CONCENTRATION UNITS: (UG/L OI UG/KG) UG/KG

1 74-87-3-------chloromethane

1 74-83-9--------bromomethane

I 75-01-4-------vinyl chloride

I 75-00-3-------chloroethane

I 75-09-2--------methylene chloride

1 67-64-1--.----acetone

1 75-15-0--------carbon disulfide

I 75-35-4-------1,1-dichloroethene

1 75-34-3--.--- - 1,1-dichloroethane

I 540-59-0-----1,2-dichloroethene (total)

I 67-66-3-------chloroform

1 107-06-2------1,2-dichloroethane

| 78-93-3--------2-butanone

I 71-55-6-- - - - 1, 1,1-trichloroethane

I 56-23-5-------carbon tetrachloride

1 108-05-4-------vinyl acetate

1 75-27-4--------bromodichloromethane

i 78-87-5--.----1,2-dichloroproparie

I 10061-01-5-----cis-1,3-dichloropropene

1 79-01-6--------trichloroethene

1 124-48-1------dibromochloromethane

1 79-00-5-------1,1,2-trichloroethane

$171-43-2-------$ benzene

I 10061-02-06----trans-1,3-dichloropropene

I 75-25-2---n---bromoform

1 108-10-1------4-methyl-2-pentanone

I 591-78-6-------2-hexanone

1 127-18-4-------tetrachloroethene

1 79-34-5--.---1, 1,2,2-tetrachloroethane

1 108-88-3-------toluene

1 108-90-7-------chlorobenzene

I 100-41-4--------ethylbenzene

1 100-42-5--------styrene

I 1330-20-7------xylene (total)

Reviewed by:

10 .

10 .

10 .

10.

5.00

10 .

5.00

5.00

5.00

5.00

5.00

5.00

10 .

5.00

5.00

10 .

5.00

5.00

5.00

5.00

5.00

5.00

5.00

5.00

5.00

10.

10.

5.00

5.00

5.00

5.00

5.00

5.00

5.00 


\section{Semivolatile Organic Analysis Data}

\begin{abstract}
Lab Name: Oak Ridge National Lab
\end{abstract} Lab Code:

Case nO: ORNL

Matrix: (soil/water) soIL

Sample wt/vol: $29.2 \mathrm{G}$

Level: (low/med) Low

\% Moisture: not dec. dec.

Extraction: (Sepf/cont/Sone) SONC

GPC Cleanup: $(Y / N) N \quad$ PH: NR
Contract: NR

SAS NO: NR SDG NO: C423-z

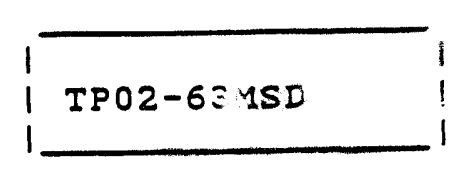

Lab Sample ID: 910307-160

Lab File ID: $>C 3726$

Date Received 7-Mar-1991

Date Analyzed: 23-AD5-1999

Date Exiracted: 12-Mar-1991

Dilution Factor: $\quad 1.0$

CONCENTRATION UNITS:

(UG/L or UG/KG) UG/KG Q

CAS NO. COMPOUND (UG/L OY UG/KG) UG/KG

$108-95-2-------p h e n \circ 1$

$1111-44-4------b i s(2-c h l o r o e t h y l) e t h e r$

1 95-57-8--------2-chlorophenol

I 541-73-1-------1,3-dichlorobenzene

I 106-46-7-------1,4-dichlorobenzene

I 100-51-6------benzyl alcohol

| 95-50-1--.----1,2-dichloroberzene

1 95-48-7--------2-methylphenol

1 108-60-1-2.---bis(2-chloroisopropyl)ether

1 106-44-5-------4-methylphenol

| $621-64-7-\ldots-\ldots-n-n i t r o s 0-d i-n-p r o p y l a m i n e$

| 67-72-1--..--nexachloroethane

| 98-95-3--------nitrobenzene

| 78-59-1--------isophorone

| 88-75-5--------2-nitrophenol

1 105-67-9-------2,4-dimethylphenol

| 65-85-0---.---benzoic acid

| $111-91-1------b i s(2-c h l o r o e t h o x y) m e t h a n e$

| 120-83-2-------2, 4-dichlorophenol

1 120-82-1-------1,2,4-trichlorobenzene

$191-20-3--\ldots-\ldots-n a p h t h a l e n e$

I 106-47-8-------4-chloroaniline

| 87-68-3--.----hexachlorobutadiene

1 59-50-7--.-.---4-chloro-3-methylphenol

I 99-57-6--.-- --2-methylnaphthalene

1 77-47-4-------hexachlorocyclopentadiene

| 88-06-2-------2,4,6-trichlorophenol

| 95-95-4-- - - - - 2, 4,5-trichlorophenol

| 91-58-7------- 2-chloronaphthalene

I 88-74-4--------2-nitroaniline

| $131-11-3-\ldots---\infty$ dimethylphthalate

| 208-96-8-------acenaphthylene

I 606-20-2-------2,6-dinitrotoluene

\begin{tabular}{|c|c|c|c|}
\hline 1 & & 1 & \\
\hline 1 & 1400. & 1 & MS \\
\hline 1 & 420 & 1 & $U$ \\
\hline 1 & 520. & 1 & MS \\
\hline 1 & 420. & 1 & $U$ \\
\hline 1 & 26 & 1 & $J M$ \\
\hline 1 & 420 & 1 & U \\
\hline 1 & 420. & 1 & $U$ \\
\hline 1 & 420. & 1 & $U$ \\
\hline 1 & 420. & 1 & $U$ \\
\hline 1 & 420 & 1 & U \\
\hline 1 & 1100. & 1 & MS \\
\hline 1 & 420 & 1 & $U$ \\
\hline 1 & 420. & 1 & $U$ \\
\hline 1 & 420. & 1 & U \\
\hline 1 & 420. & 1 & U \\
\hline 1 & 420 & 1 & U \\
\hline 1 & 2100. & 1 & U \\
\hline 1 & 420 & 1 & U \\
\hline 1 & 420 . & 1 & $U$ \\
\hline 1 & 470. & 1 & MS \\
\hline 1 & 420. & 1 & U \\
\hline 1 & 420. & 1 & $U$ \\
\hline 1 & 420 & 1 & U \\
\hline 1 & 2200 & 1 & MS \\
\hline 1 & 420 & $!$ & U \\
\hline 1 & 420. & 1 & U \\
\hline 1 & 420 & 1 & $U$ \\
\hline 1 & 2100. & 1 & U \\
\hline 1 & 420. & 1 & U \\
\hline 1 & 2100 & 1 & $U$ \\
\hline 1 & 420 & 1 & U \\
\hline 1 & 420. & 1 & $U$ \\
\hline 1 & 420. & 1 & U \\
\hline
\end{tabular}


Semivolatile Organic Analysis Data

Las Name: Oak Ridge National Lab

Lab Code:

Case nO: ORNL

Matrix: (soil/water) soIl

Sample wt/vol: $29.2 \mathrm{G}$

Level: (low/med) LOW

\% Moisture: not dec. dec.

Extraction: (Sepf/Cont/Sonc) SONC

GPC Cleanup: $(Y / N) N$

PH : NR
Contract: NR

SAS NO: NR
EPA SAMPLE NO.

IPO2-63MSD

SDG NO: $C 423-2$

Lab Sample ID: 910307-160

Lab File ID: $>C 3736$

Date Received 7-Mar-1991

Date Analyzed: 23-Apr-1991

Date Extracted: 12-Mar-1991

Dilution Factor: $\quad 1.0$

CONCENTRATION UNITS:

CAS NO.

COMPOUND

(UG/L OY UG/KG) UG/KG

Q

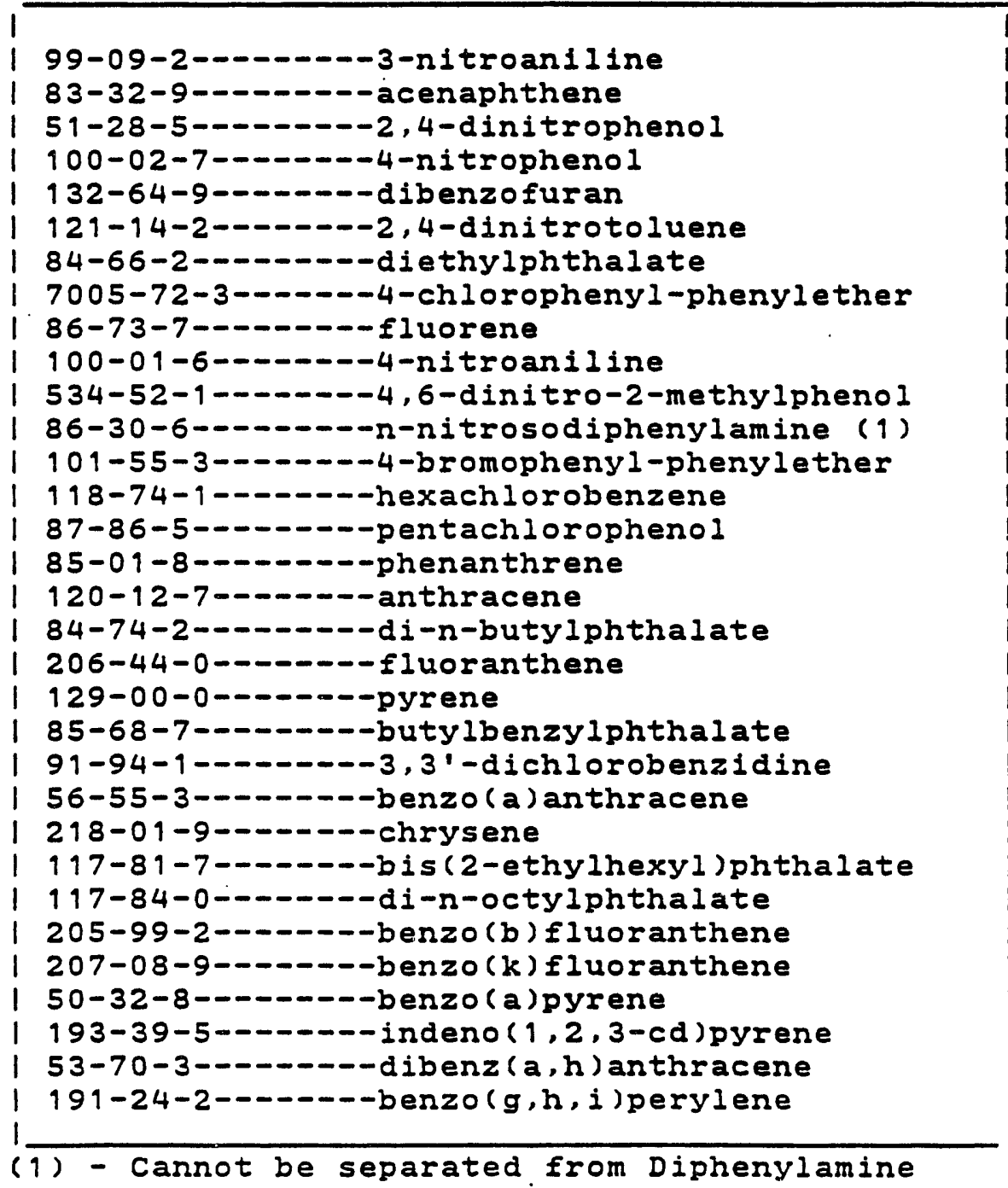

\begin{tabular}{|c|c|c|c|}
\hline 1 & & 1 & \\
\hline 1 & 2100. & 1 & $U$ \\
\hline 1 & 1000. & 1 & MS \\
\hline 1 & 2100. & 1 & $U$ \\
\hline 1 & 1500. & 1 & JM \\
\hline 1 & 420 . & 1 & $U$ \\
\hline 1 & 1100. & 1 & MS \\
\hline 1 & 420 . & 1 & $U$ \\
\hline 1 & 420. & 1 & $U$ \\
\hline I & 420. & 1 & $U$ \\
\hline 1 & 2100. & 1 & U \\
\hline I & 2100. & 1 & $U$ \\
\hline 1 & 420. & 1 & U \\
\hline 1 & 420. & 1 & $U$ \\
\hline 1 & 420. & 1 & $U$ \\
\hline 1 & 3700 . & 1 & MS \\
\hline 1 & 420. & 1 & $U$ \\
\hline I & 420. & 1 & $U$ \\
\hline 1 & 420. & 1 & U \\
\hline I & 420. & 1 & $U$ \\
\hline 1 & 1700. & 1 & MS \\
\hline 1 & 420 & 1 & $\mathrm{U}$ \\
\hline 1 & 840. & 1 & U \\
\hline 1 & 420. & 1 & $U$ \\
\hline 1 & 420. & 1 & U \\
\hline 1 & 420. & 1 & $U$ \\
\hline 1 & 420. & 1 & $U$ \\
\hline 1 & 420 & 1 & $U$ \\
\hline 1 & 420. & 1 & $U$ \\
\hline 1 & 420. & 1 & $U$ \\
\hline I & 420. & 1 & $U$ \\
\hline 1 & 420. & 1 & $U$ \\
\hline 1 & 420. & 1 &.$U$ \\
\hline
\end{tabular}

Reviewed by:

Date : 


\section{VOLATILE ORGANICS ANALYSIS DATA SHEET}

EPA SAMPLE NO.

Lab Name: Oak Ridge National Lab

Lab Code:

Case no: ORNL

Matrix: (soil/water) soIL

Sample wt/vol: 5 G

Level: (low/med) Low

\% Moisture: not dec.

Colums: (pack/cap) CAP
Contract: NR

TPOS-62
SAS NO: NR
SDG NO: 0308
Lab Sample ID: 910307-161

Lab File ID: $\quad>01208$

Date Received 7-Mar-1991

Date Analyzed: 9-Mar-1991

Dilution Factor: $\quad 1.0$

CAS NO.

COMPOUND

CONCENTRATION UNITS:

(UG/L Or UG/KG) UG/KG

Q

\begin{tabular}{|c|}
\hline 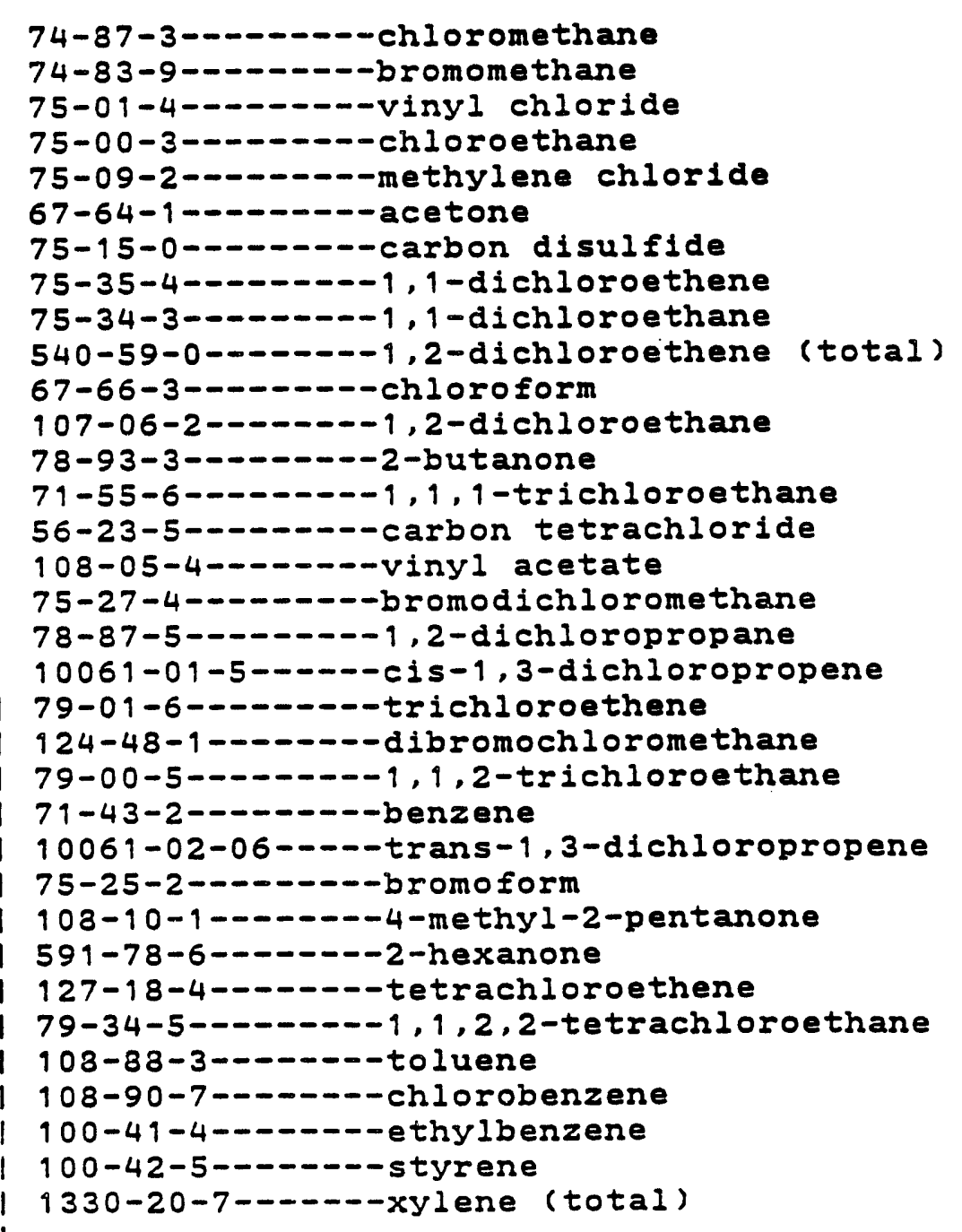 \\
\hline
\end{tabular}

Reviewed by:

10.

10.

10 .

10.

5.00

10 .

5.00

5.00

5.00

5.00

5.00

5.00

10 .

5.00

5.00

10.

5.00

5.00

5.00

5.00

5.00

5.00

5.00

5. 00

5. 00

10.

10.

5.00

5.00

2.00

3.00

5.00

5.00

5.00 
Lab Name: Qak Ridge National Lab

Lab Code: Case no: ORNL
Contract: NR

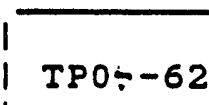

1 TPO $\div-62$
Matrix: (soil/water) soIl

Sample wt/vol: $\quad 30.1 \mathrm{G}$

Level: ( low/med) MED

\% Moisture: not dec. dec.

Extraction: (Sepf/Cont/Sonc) soNC

GPC Cleanup: $(Y / N) N$

PH : NR
SAS NO: NR
SDG No: C423-2
Lab Sample ID: 910307-161

Lab File ID: >C3741

Date Received 7-Mar-1991

Date Aralyzed: 24-Apr-1991

Date Extracted: 12-Mar-1991

Dilution Factor:

10

CAS NO.

COMPOUND

CONCENTRATION UNITS:

(UG/L or UG/KG) UG/KG

$\mathbf{Q}$

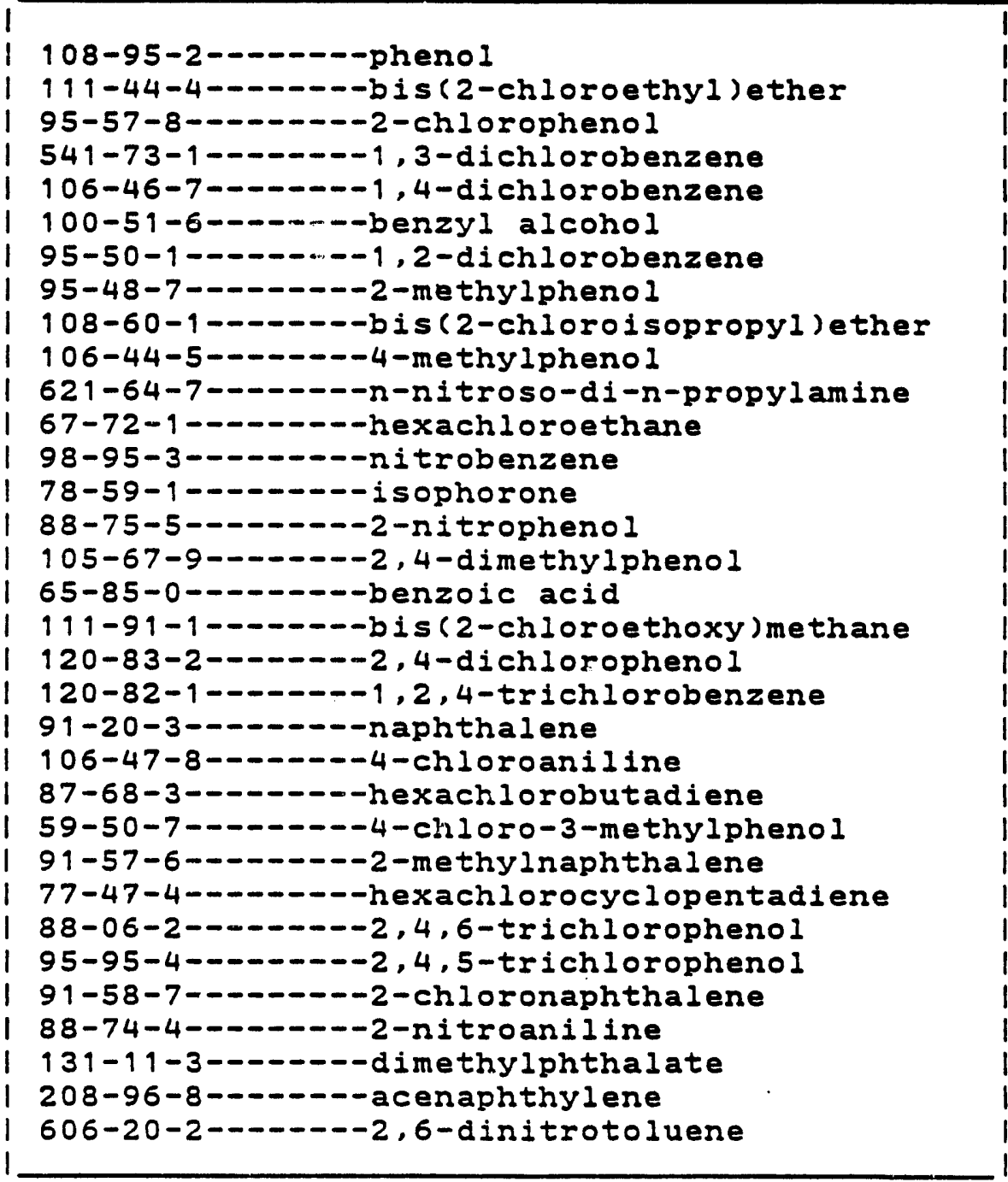

4100

4100 .

4100 .

4100 .

4100 .

4100 .

4100 .

4100.

4100 .

4100.

4100

4100 .

4100 .

4100 .

4100 .

4100 .

20000

4100.

4100 .

4100

4100 .

4100

4100 .

4100 .

4100 .

4100 .

4100.

20000.

4100 .

20000 .

4100 .

4100 .

4100 .

\begin{tabular}{l|} 
UD \\
$U D$ \\
$U D$ \\
$U D$ \\
$U D$ \\
$U D$ \\
$U D$ \\
$U D$ \\
$U D$ \\
$U D$ \\
$U D$ \\
$U D$ \\
$U D$ \\
$U D$ \\
$U D$ \\
$U D$ \\
$U D$ \\
$U D$ \\
$U D$ \\
$U D$ \\
$U D$ \\
$U D$
\end{tabular}


Semivolatile organic Analysis Data

Lab Name: Oak Ridge National Lab Contract: NR

T TP05-62

Lab Code: Case no: ORNL

SAS NO: NR

SDG NO: C423-2

Matrix: (soil/water) soIL

Lab Sample ID: 910307-161

Sample wt/vol: $\quad 30.1 \mathrm{G}$

Lab File ID: >C3741

Level: ( low/med) MED

Date Received 7-Mar-1991

\% Moisture: not dec. dec.

Date Analyzed: 24-Apr-1991

Extraction: (Sepf/Cont/Sonc) SONC

Date Extracted: 12-Mar-1991

GPC Cleanup: $(Y / N) N \quad$ PH: NR

Dilution Factor: $\quad 10$

CAS NO.

COMPOUND

CONCENTRATION UNITS:

(UG/L OI UG/KG) UG/KG $Q$

99-09-2--n----3-nitroaniline

83-32-9--------acenaphthene

I 51-28-5-------2,4-dinitrophenol

I 100-02-7------4-nitrophenol

I 132-64-9-------dibenzofuran

I 121-14-2-------2,4-dinitrotoluene

1 84-66-2--------diethylphthalate

1 7005-72-3-n---4-chlorophenyl-phenylether

1 86-73-7--------fluorene

1 100-01-6-n---4-nitroaniline

I 534-52-1------4,6-dinitro-2-methylphenol

1 86-30-6------n-nitrosodiphenylamine (1)

1 101-55-3------4-bromophenyl-phenylether

| 118-74-1-------hexachlorobenzene

| 87-86-5--.-----pentachlorophenol

l 85-01-8--------phenanthrene

1 120-12-7-------anthracene

1 84-74-2-------di-n-butylphthalate

1 206-44-0-------fiuoranthene

1 129-00-0---.---pyrene

| 85-68-7------butylbenzylphthalate

| 91-94-1-------3,3'-dichlorobenzidine

| 56-55-3--------benzo (a ) anthracene

| 218-01-9-------chrysene

(117-81-7-------bis(2-ethylhexyl)phthalate

1 117-84-0-------di-n-octylphthalate

1 205-99-2-------benzo(b) fluoranthene

| 207-08-9--..---benzo(k) fluoranthene

| 50-32-8-.-.---benzo(a) pyrene

1 193-39-5-------indeno $(1,2,3-c d)$ pyrene

1 53-70-3--------dibenz $(\mathrm{a}, \mathrm{h})$ anthracene

191-24-2------benzo( $g, h, i$ ) perylene

(1) - Cannot be separated from Diphenylamine

Reviawed by:

Date : 


\section{Semivolatile Organic Analysis Data}

EPA SAMPLE NO.

Request Number: OAL94177

TPOS-62

Procodure Number: 8240 Matrix: SOIL AND WATER

Series:

Frequency:

Charge Number:

33707380

Customer Name: SIEGRIST

Lab Sample ID: 910307-161

Sample wt/vol: $30.1 \mathrm{G}$

Lab File ID: >C3741

Date Sampled:

Date Received 7-Mar-1991 13:00

\% Moisture: not dec.

dec:

Date Analyzed: 24-Apr-1991

Material Description FUEL CONTAMINATION

Date of Report: 16-MAY-91

Number TICs found: 20

CONCENTRATION UNITS:

(UG/L Or UG/KG) UG/KG

\begin{tabular}{|c|c|c|c|c|c|c|c|}
\hline CAS NO. & I COMPOUND NAME & 1 & RT & 1 & CONC & & $Q$ \\
\hline 1 & 1 & 1 & & 1 & & 1 & \\
\hline 11. & I UNKNOWN & 1 & 14.81 & 1 & 320 . & 1 & $\mathrm{~J}$ \\
\hline 12. & I UNKNOWN HYDROCARBON & 1 & 15.49 & 1 & 230. & 1 & $\mathrm{~J}$ \\
\hline 13. & | UNKNOWN & 1 & 15.92 & 1 & 200. & 1 & $\mathrm{~J}$ \\
\hline 14. & I UNKNOWN & 1 & 16.31 & 1 & 300. & 1 & $\mathrm{~J}$ \\
\hline 15. & I UNKNOWN HYDROCARBON & 1 & 17.04 & 1 & 550. & 1 & $\mathrm{~J}$ \\
\hline 16. & I UNKNOWN & 1 & 17.19 & 1 & 580 . & 1 & $\mathrm{~J}$ \\
\hline 17. & I UNKNOWN & 1 & 17.31 & 1 & 310. & 1. & $\mathrm{~J}$ \\
\hline 18. & IDIMETHYL NA.PHTHALENE & 1 & 17.83 & 1 & 370 . & 1 & $\mathrm{~J}$ \\
\hline 19. & I UNKNOWN & 1 & 17.90 & 1 & 860. & 1 & $\mathrm{~J}$ \\
\hline 110. & I UNKNOWN & 1 & 17.95 & 1 & 570. & 1 & $\mathrm{~J}$ \\
\hline 111. & I UNKNOWN & 1 & 18.11 & 1 & 360. & 1 & $\mathrm{~J}$ \\
\hline 112. & I UNKNOWN HYDROCARBON & 1 & 18.24 & 1 & 1000. & 1 & $\mathrm{~J}$ \\
\hline 113. & I UNKNOWN & 1 & 18.48 & 1 & 970 & 1 & $\mathrm{~J}$ \\
\hline 194. & I UNKNOWN & 1 & 19.35 & 1 & 330. & 1 & $\mathrm{~J}$ \\
\hline 115. & I UNKNOWN & 1 & 19.45 & I & 340. & 1 & $\mathrm{~J}$ \\
\hline 116. & I UNKNOWN & 1 & 19.57 & 1 & 540. & 1 & $\mathrm{~J}$ \\
\hline 197. & I UNKNOWN & 1 & 19.78 & 1 & 650. & 1 & $\mathrm{~J}$ \\
\hline 118. & I UNKNOWN HYDROCARBON & 1 & 20.64 & 1 & 940. & 1 & $\mathrm{~J}$ \\
\hline 119. & I UNKNOWN HYDROCARBON & 1 & 21.35 & 1 & 3800. & 1 & $\mathrm{~J}$ \\
\hline 120. & I UNKNOWN HYDROCARBON & 1 & 23.44 & 1 & 550 & 1 & $\mathrm{~J}$ \\
\hline
\end{tabular}


Lab Name: Oak Ridge National Lab Lab Code:

Case no: ORNL

Matrix: (soil/water) WATER

Sample wt/vol:

$5 \mathrm{ML}$

Level: (low/med) Low

\% Moisture: not dec.

Colums: (pack/cap) CAP contract:

SAS No:

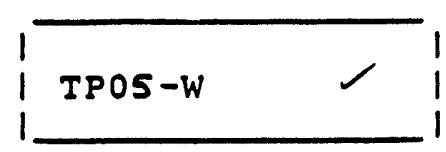

SDG NO: 0309
Lab Sample ID: 910307-164

Lab File ID: >01232

Date Received 7-Mar-1991

Date Aralyzed: 9-Mar-1991

Dilution Factor: 1.0

CAS NO.

COMPOUND

CONCENTRATION UNITS, (UG/L OI UG/KG) UG/L

74-87-3---n---chloromethane

1 74-23-9--------bromomethane

1 75-01-4--------vinyl chloride

1 75-00-3--n----chloroethane

1 75-09-2--------methylene chloride

I 67-54-1------- acetone

1 75-15-0--.----carbon disulfide

I 75-35-4---n--- 1, 1-dichloroethene

1 75-34-3--------1,1-dichloroethane

I 540-59-0-------1,2-dichloroethene

| 67-66-3--.-.--chloroform

| 107-06-2--.----1,2-dichloroethane

I 78-93-3------- -2-butanone

I 71-55-6-- - - - 1, 1,1-trichloroethane

I 56-23-5--.----carbon tetrachloride

| 108-05-4-------vinyl acetate

| 75-27-4-n-_---bromodichloromethane

1 78-87-5--------1,2-dichloropropane

I 10061-01-5-----cis-1,3-dichloropropene

1 79-01-6--------trichloroethene

| 124-48-1---n--dibromochloromethane

1 79-00-5---n---1,1,2-trichloroethane

1 71-43-2--------berzene

1 10061-02-06----trans-1,3-dichloropropene

1 75-25-2--------bromoform

1 108-10-1------4-methyl-2-pentanone

I 591-78-6-------2-hexanone

1 127-18-4-------tetrachloroethene

1 79-34-5-- - - - 1, 1,2,2-tetrachloroethane

| 108-88-3-------toluene

| 108-90-7------chlorobenzene

I 100-41-4-------ethylbenzene

1 100-42-5-------styrene

(1330-20-7------xylene (total) (tota1)

\begin{tabular}{|c|c|c|c|}
\hline 1 & & 1 & \\
\hline I & 10. & 1 & $U$ \\
\hline I & 10. & 1 & $U$ \\
\hline 1 & 10. & 1 & U \\
\hline I & 10. & $!$ & U \\
\hline 1 & 5.00 & 1 & U \\
\hline 1 & 10. & 1 & $U$ \\
\hline$!$ & 20.0 & 1 & \\
\hline 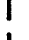 & 5.00 & 1 & U \\
\hline 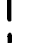 & 5.00 & 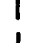 & U \\
\hline 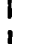 & 5.00 & 1 & I \\
\hline 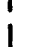 & 5.00 & 1 & U \\
\hline 1 & 10. & 1 & $U$ \\
\hline 1 & 5.00 & 1 & $U$ \\
\hline 1 & 5.00 & 1 & $\mathrm{U}$ \\
\hline 1 & 10. & 1 & U \\
\hline 1 & 5.00 & 1 & U. \\
\hline 1 & 5.00 & 1 & U \\
\hline 1 & 5.00 & 1 & $U$ \\
\hline 1 & 5.00 & 1 & $\mathrm{U}$ \\
\hline ! & 5.00 & 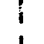 & U \\
\hline$!$ & 5.00 & 1 & U \\
\hline 1 & 5.00 & 1 & U \\
\hline 1 & 5.00 & 1 & U \\
\hline 1 & 5.00 & 1 & U \\
\hline ! & 10. & 1 & U \\
\hline 1 & 10. & 1 & U \\
\hline 1 & 5.00 & 1 & U \\
\hline 1 & 5.00 & 1 & U \\
\hline ! & 5.00 & 1 & U \\
\hline I & 33.0 & 1 & \\
\hline 1 & 5.00 & 1 & $U$ \\
\hline 1 & 5.00 & 1 & U \\
\hline & 5.00 & 1 & U \\
\hline
\end{tabular}

Date : 
Semivolatile organic Analysis Data

EPA SAMPLE NO.

Lab Name: Oak Ridge National Lab

Lab Code:

Case no: NR

Matrix: (soil/water) WATER

Sample wt/vol: $\quad 130 \mathrm{ML}$

Level: (low/med) Low

\% Moisture: not dec.

dec.

Extraction: (Sepf/Cont/Sone) SEPF

GPC Cleanup: $(Y / N) N$

$\mathrm{pH}: 7.80$
Contract: NR

SAS NO: NR

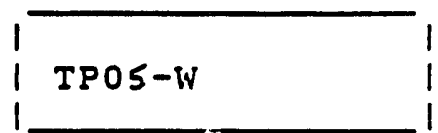

SUG NO: C425

Lab Sample ID: 990307-164

Lab File ID: $\quad>C 3768$

Date Received 7-Mar-1991

Date Analyzed: 25-Apr-1991

Date Extracted: 18-Mar-1991

Dilution Factor: $\quad \mathbf{7 . 7}$

CONCENTRATION UNITS:

CAS NO.

COMPOUND

(UG/L or UG/KG) UG/L

Q

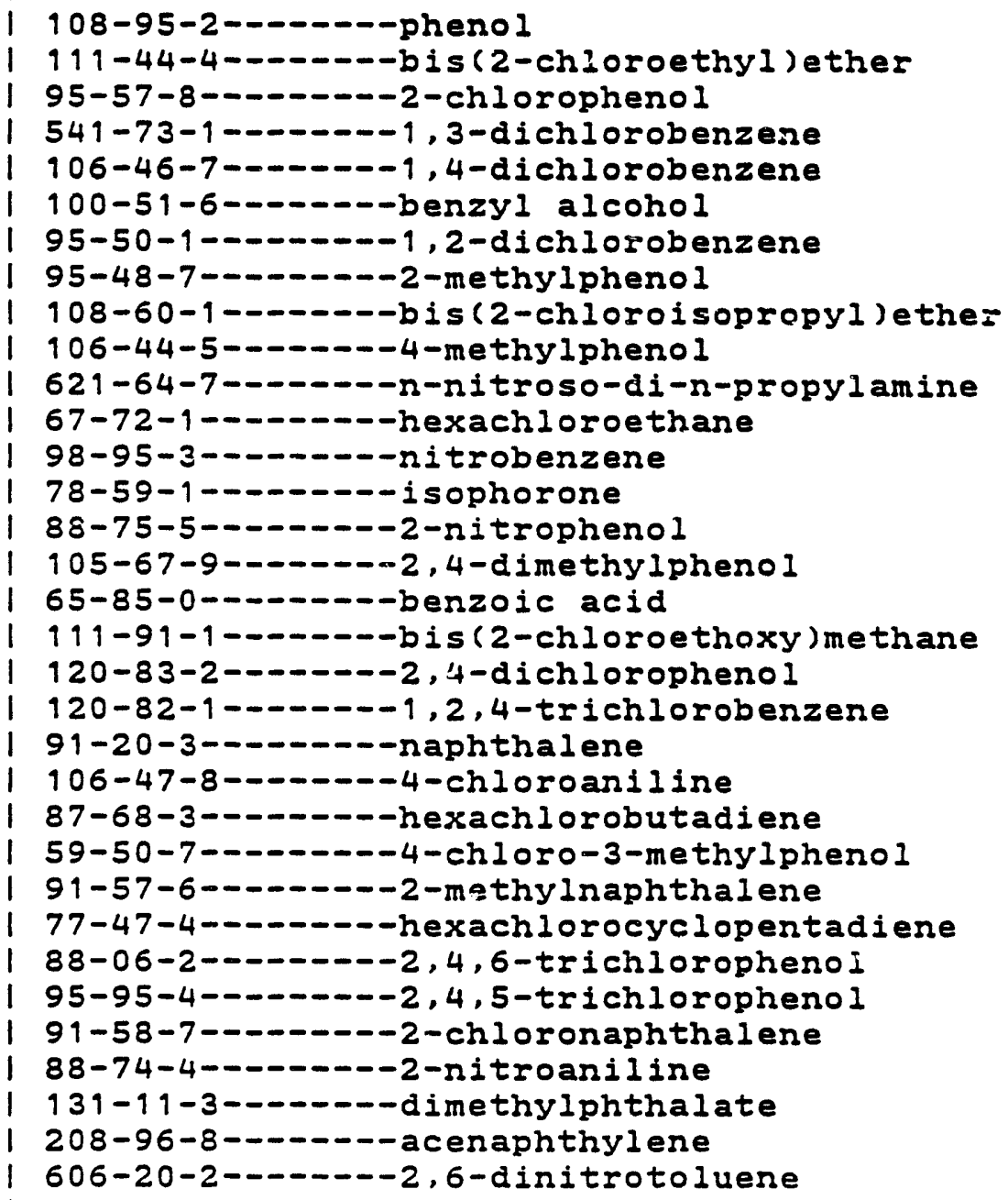


Lab Name: Oak Ridge National Lab

Lab code:

Case no: NR

Matrix: (soil/water) WATER

Sample wt/vol: $\quad 130 \mathrm{ML}$

Level: (low/med) Low

\% Moisture: not dec. dec.

Extraction: (Sepf/Cont/Sonc) SEPF

GPC Cleasup: $(Y / N)$ N

pH: 7.80
Contract: NR

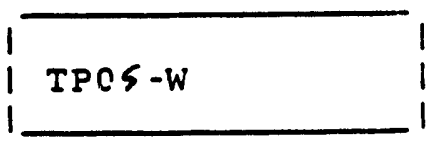

SDG NO: $c 425$
SAS NO: NR

CONCENTRATION UNITS:

CAS NO. COMPOUND (UG/L OT UG/KG) UG/L

\begin{tabular}{|c|}
\hline 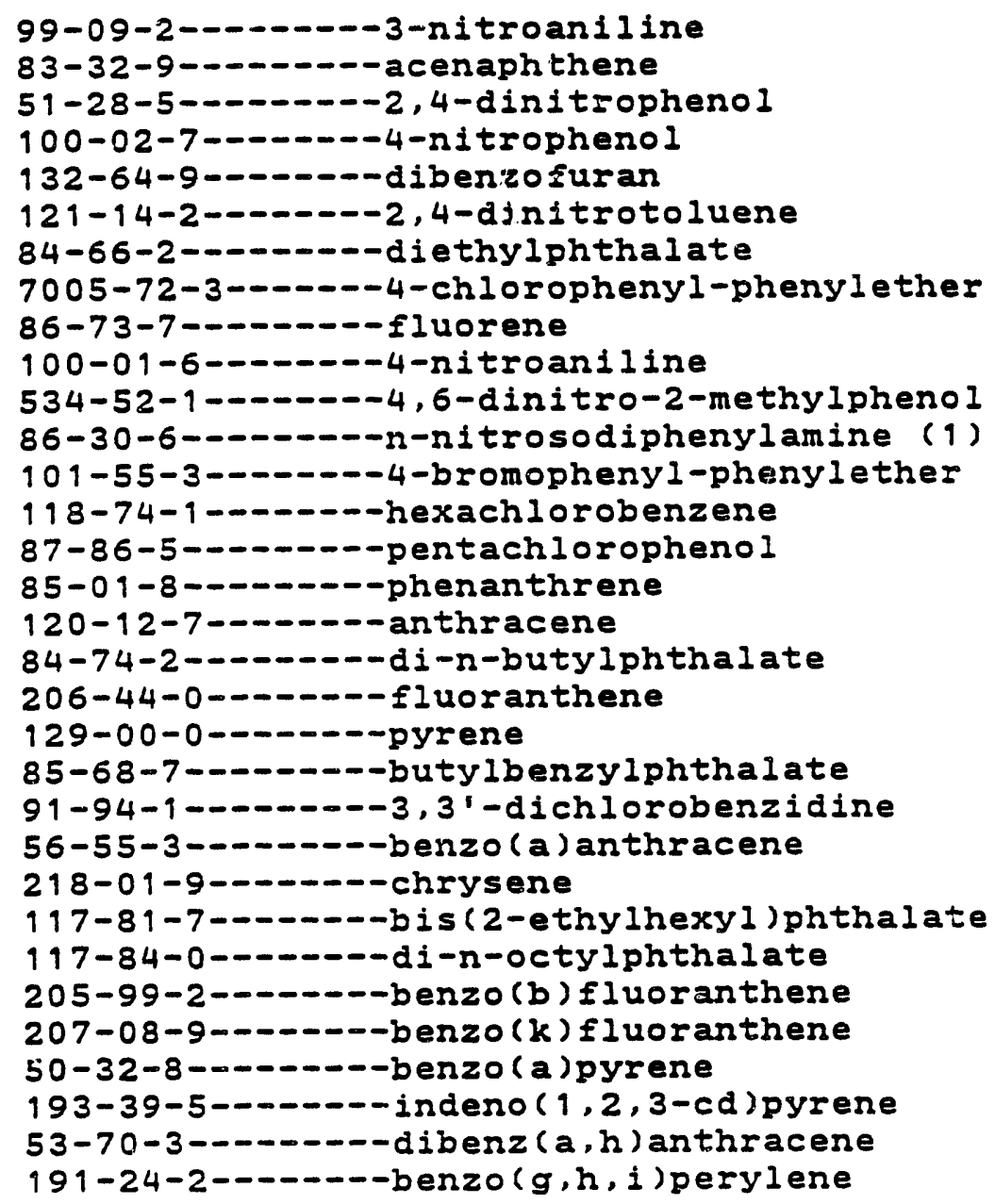 \\
\hline
\end{tabular}

(1) - Cannot be separated from Diphenylamine

\begin{tabular}{|c|c|c|c|}
\hline 1 & & 1 & \\
\hline 1 & 380. & 1 & U \\
\hline I & 77 & 1 & $U$ \\
\hline 1 & 380. & 1 & $U$ \\
\hline 1 & 380. & 1 & U \\
\hline 1 & 77 & 1 & $U$ \\
\hline 1 & 77. & 1 & U \\
\hline 1 & 77. & 1 & U. \\
\hline 1 & 77. & 1 & U \\
\hline 1 & 77 . & 1 & U \\
\hline 1 & 380. & 1 & U \\
\hline 1 & 380. & 1 & U \\
\hline 1 & 77 & 1 & $U$ \\
\hline 1 & 77 . & 1 & $U$ \\
\hline 1 & 77 & 1 & $U$ \\
\hline 1 & 380. & 1 & $U$ \\
\hline 1 & 77 & 1 & $U$ \\
\hline 1 & 77. & 1 & U \\
\hline 1 & 77. & 1 & U \\
\hline 1 & 77. & 1 & U \\
\hline 1 & 77 & 1 & U \\
\hline 1 & 170. & 1 & B \\
\hline 1 & 150. & 1 & U \\
\hline 1 & 77 & 1 & $U$ \\
\hline 1 & 77. & 1 & $U$ \\
\hline 1 & 77. & 1 & U \\
\hline 1 & 77. & I & $U$ \\
\hline 1 & 77 . & 1 & $U$ \\
\hline 1 & 77. & 1 & U \\
\hline 1 & 77. & 1 & $\mathbf{U}$ \\
\hline 1 & 77 . & 1 & U \\
\hline 1 & 77 . & 1 & U \\
\hline 1 & 77. & 1 & $U$ \\
\hline
\end{tabular}

Date : 
Semivolatile organic Analysis Data

EPA SAMPLE NO.

Request Number: OAL94177

TPOS-W

Procedure Number: 8240

Matrix: SOIL AND WATER

Series:

Frequency :

Charge Number:

33707380

Customer Name: SIEGRIST

Lab Sample ID: 910307-164

Sample wt/vol: $\quad 130 \mathrm{ML}$

Lab File ID: $\quad>C 3768$

Date Sampled:

Date Received 7-Mar-1991 13:00

\% Moisture: not dec.

dec:

Date Analyzed: 25-Apr-1991

Material Description FUEL CONTAMINATION

Date of Report: 16-MAY-91

Number TICs found: 20

CONCENTRATION UNITS:

(UG/L or UG/KG) UG/L

\begin{tabular}{ll}
\hline CAS NO. & I COMPOUND NAME \\
\hline 1. & I UNKNOWN HYDROCARBON \\
12. & IUNKNOWN \\
3. & IUNKNOWN HYDROCARBON \\
14. & IUNKNOWN \\
15. & IUNKNOWN \\
16. & IUNKNOWN HYDROCARBON \\
17. & IUNKNOWN \\
18. & IUNK NAPHTHALENE, -DIMETHYL \\
19. & IUNK NAPHTHALENE, -DIMETHYL \\
110. & IUNK NAPHTHALENE, -DIMETHYL \\
119. & IUNKNOWN \\
112. & IUNKNOWN HYDROCARBON \\
113. & IUNKNOWN HYDROCARBON \\
114. & IUNKNOWN \\
115. & IUNKNOWN HYDROCARBON \\
116. & IUNKNOWN HYDROCARBON \\
117. & IUNKNOWN \\
118. & IUNKNOWN HYDROCARBON \\
119. & IUNKNOWN HYDROCARBON \\
120. & IUNKNOWN HYDROCARBON \\
11 & I
\end{tabular}

Reviewed by:

Date : 


\section{VOLATILE ORGANICS ANALYSIS DATA SHEET}

Lab Name: Oak Ridge National Lab

Lab Code:

Case no:

Matrix: (soil/water) soIL

Sample wt/vol: $\quad .005 \mathrm{G}$

Level: (low/med) MED

\% Moisture: not dec.

Column: (pack/cap) DIL-GC
Contract :

SAS NO:
EPA SAMPLE NO.

KWAJOIL -2

SDG NO:

Lab Sample ID: 910307-165

Lab File ID:

Date Received 7-Mar-1991

Date Analyzed: 19-Mar-1991

Dilution Factor: $\quad 100$

CONCENTRATION UNITS :

CAS NO. COMPOUND (UG/L OI UG/KG) $M G / K G$

Q

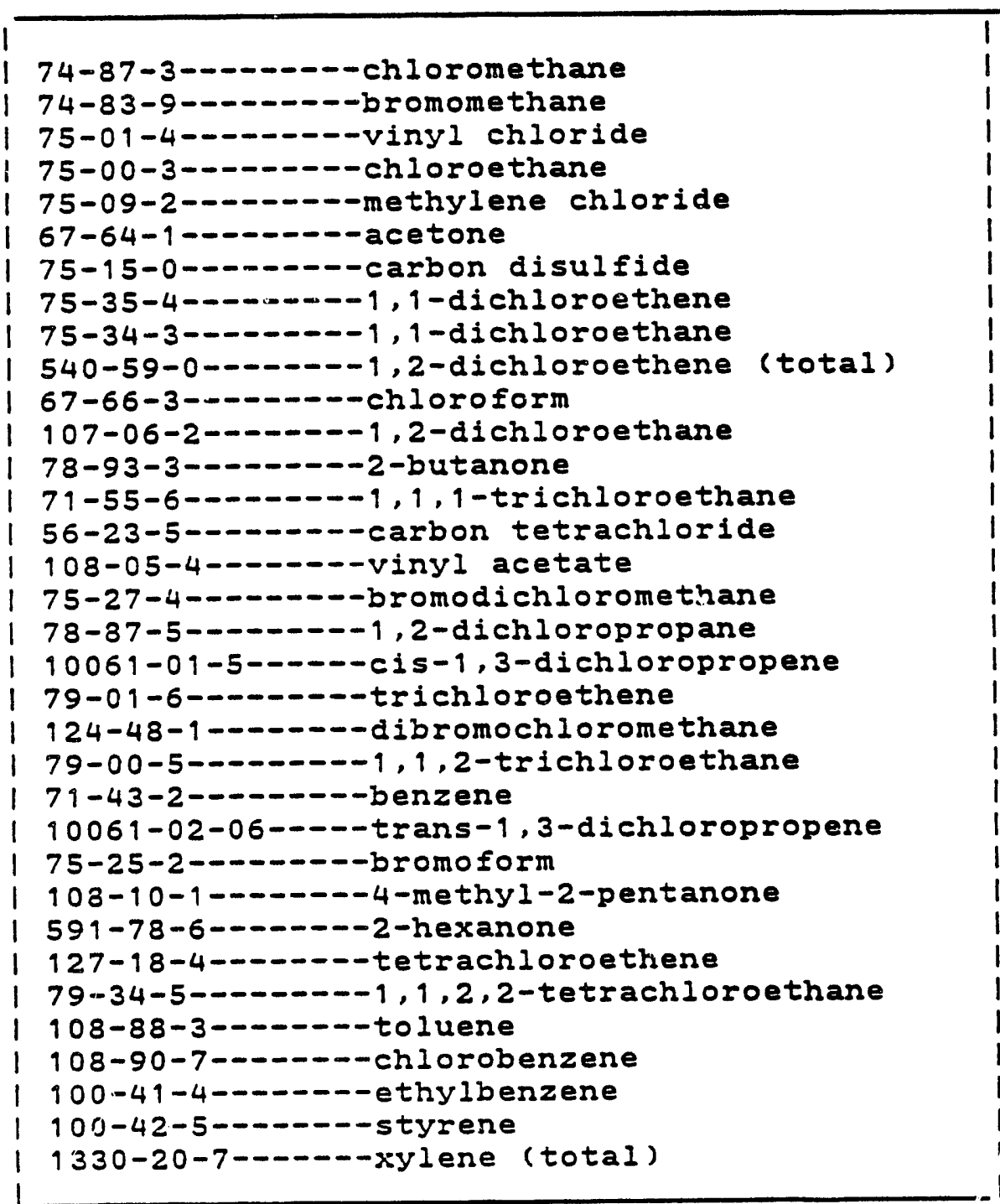

Reviewed by:

1000

1000 .

9000 .

1000 .

500 .

1000 .

500 .

500 .

500 .

500 .

500 .

500 .

1000 .

500 .

500 .

1000 .

500 .

500 .

500 .

500 .

500 .

500 .

500 .

500 .

500 .

1000 .

1000 .

500 .

500 .

500 .

500 .

500 .

500 .

500 .

$\begin{array}{ll}U & 1 \\ U & 1 \\ U & 1 \\ U & 1 \\ U & 1 \\ U & 1 \\ U & 1 \\ U & 1 \\ U & 1 \\ U & 1 \\ U & 1 \\ U & 1 \\ U & 1 \\ U & 1 \\ U & 1 \\ U & 1 \\ U & 1 \\ U & 1 \\ U & 1 \\ U & 1 \\ U & 1 \\ U & 1 \\ U & 1 \\ U & 1 \\ U & 1 \\ U & 1 \\ U & 1 \\ U & 1 \\ U & 1 \\ U & 1 \\ U & \end{array}$

Date: 
Semivolatile Organic Analysis Data

EPA SAMPLE NO.

Lab Name: Oak Ridge National Lab Contract: NR KWAJOIL -2

Lab Code

Case no: NR

SAS NO: ORNL

SDG NO: $C 502$

Matrix: (soil/water) soIL

Sample wt/vol:

$0.1 \mathrm{G}$

Level: (low/med) MED

\% Moisture: not dec. dec.

Extraction: (Sepf/Cont/Sonc) DIL
PH : NR
Lab sample ID: 910307-165

Lab File ID: $\quad>C 3798$

Date Received 7-Mar-1991

Date Analyzed: 2-May-1991

Date Extracted: 12-Mar-1991

Diluticn Factor: $\quad 100$

CAS NO.

COMPOUND

CONCENTRATION UNITS:

(UG/L OI UG/KG) MG/KG

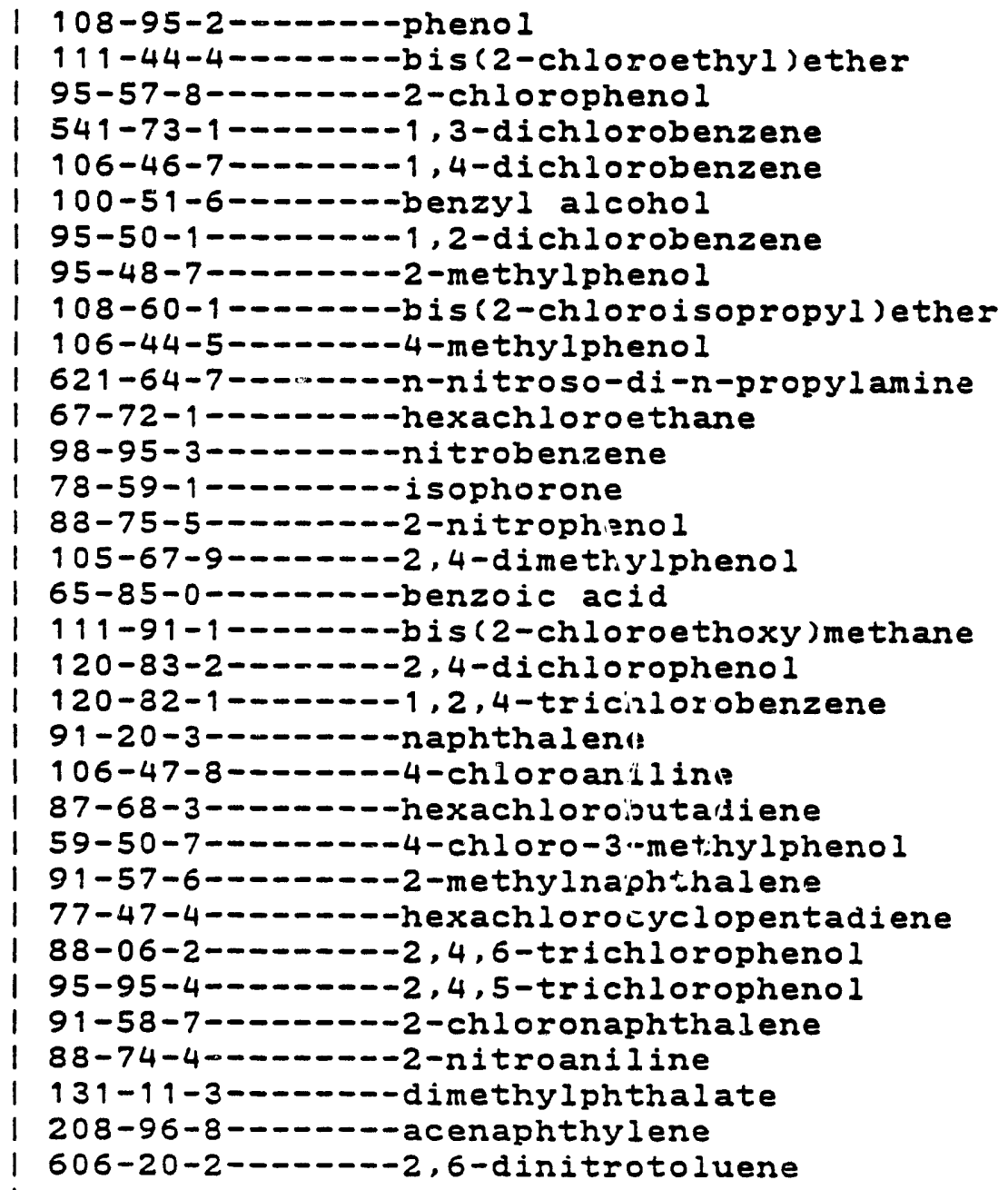


Semivolatile Organic Analysis Data

Lab Name: Oak Ridge National Lab

Lab code:

Case no: NR

Matrix: (soil/water) soIL

Sample wt/vol: $0.1 \mathrm{G}$

Level: (low/med) MED

\% Moisture: not dec. dec.

Extraction: (sepf/Cont/Sonc) DIL

GPC Cleanup: $(Y / N) N$

PH : NR contract : NR

SAS NO: ORNL
EPA SAMPLE NO.

KWAJOIL - 2

Lab Sample ID: 910307-165

Lab File ID: $\quad>C 3798$

Date Received 7-Mar-1991

Date Aralyzed: 2-May-1991

Date Extracted: 12-Mar-1991

Dilution Factor: $\quad 100$

CONCENTRATION UNITS:

CAS NO.

COMPOUND

(UG/L OI UG/KG) MG/KG

Q

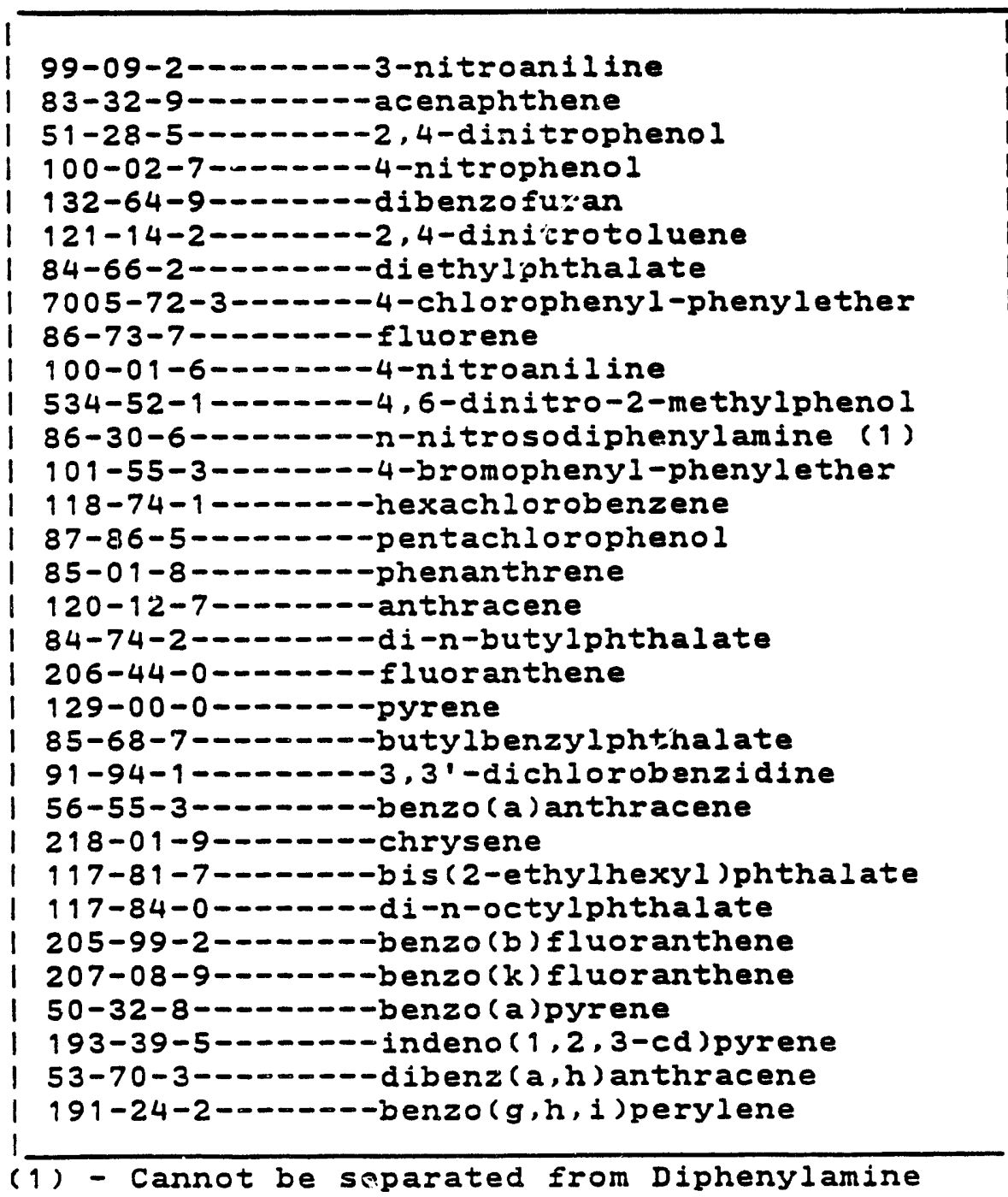

Reviewed by:

5000.
1000.
5000.
5000.
1000.
1000.
1000.
1000.
1000.
5000.
5000.
1000.
1000.
1000.
5000.
2200.
1000.
1000.
1000.
1000.
1000.
2000.
1000.
1000.
1000.
1000.
1000.
1000.
1000.
1000.
1000.
1000.

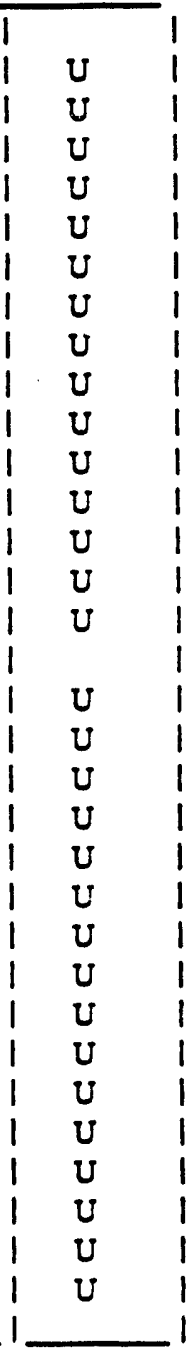

Date : 
Procedure Number: 8240

Matrix: SOIL AND WATER

Series:

Frequency :

Charge Number:

33707380

Customer Name: SIEGRIST

Sample wt/vol: $0.1 \mathrm{G}$

Date Sampled:

\% Moisture: not dec.

dec:

Material Description FUEL CONTAMINATION

Number TICs found: 20
Lab Sample ID: 910307-165

Lab File ID: $\quad>C 3798$

Date Received 7-Mar-1991 13:00

Date Aralyzed: 2-May-1991

Date of Report: 16-MAY-91

CONCENTRA:IION UNITS :

(UG/L or UG/KG) $M G / K G$

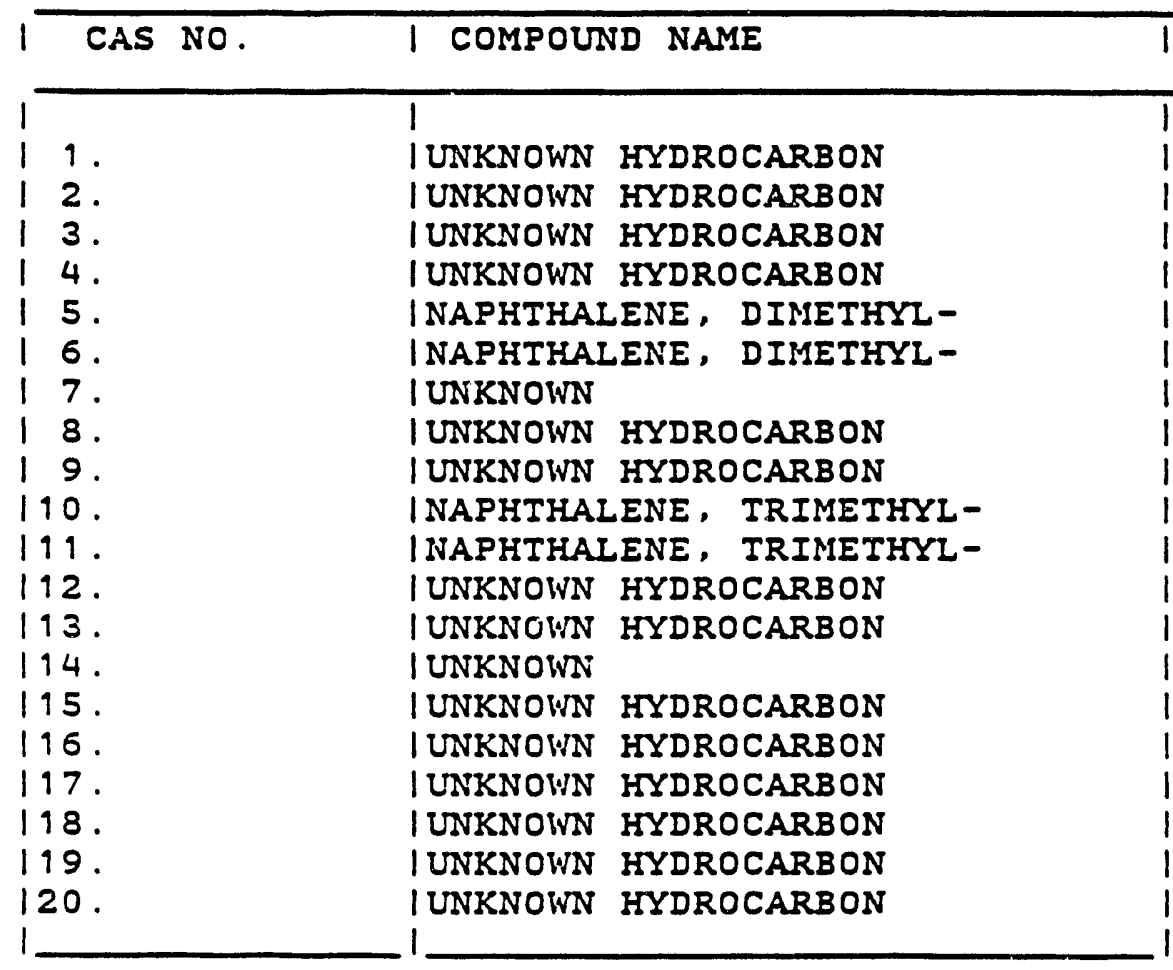

Reviewed by:

\begin{tabular}{l|l|l} 
RT & CONC
\end{tabular}

12.53

14.22

16.92

17.26

17.69

17.75

17.96

18.11

18.64

19.21

19.431

19.93

20.52

20.68

21.15

21.23

22.26

23.38

24.49

25.39

I.
Date :
$2600.1 \mathrm{~J}$ $4600.1 \mathrm{~J} 1$ $3300.1 \mathrm{~J}$ $18000.1 \mathrm{~J}$ $3400.1 \mathrm{~J}$ $3600.1 \mathrm{~J}$ $4000.1 \mathrm{~J}$ $8700.1 \mathrm{~J}$ $23000.1 \mathrm{~J}$ 3600.13 $4100.1 \mathrm{~J}$ $28000.1 \mathrm{~J}$ $1400.1 \mathrm{~J}$ $750.1 \mathrm{~J}$ $4800.1 \mathrm{~J}$ $3100.1 \mathrm{~J}$ $1000.1 \mathrm{~J}$ $2600.1 \mathrm{~J}$ $1900.1 \mathrm{~J}$ 1100 . 1. 
APPENDIX D

LABORATORY RESULTS FOR INORGANIC ANALYSES 


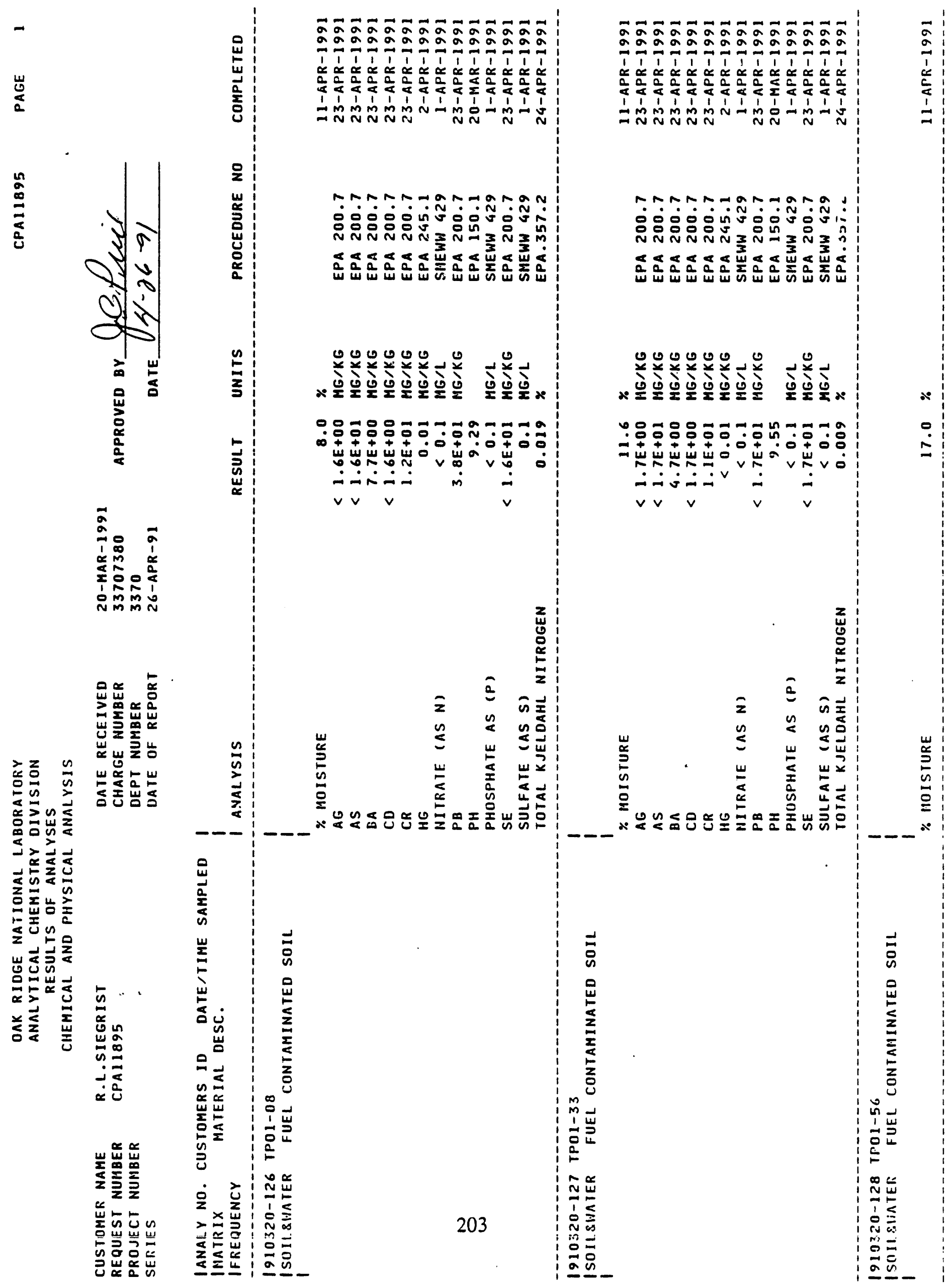


$n$
0
0
0
0
0
0
0
$\frac{1}{0}$
0
0
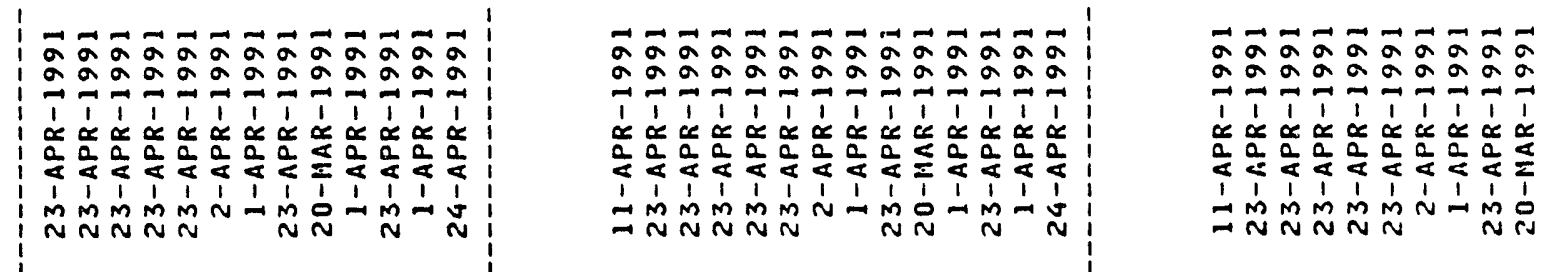

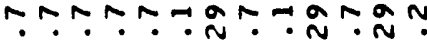

응ㅇㅇㅇㅢ 只

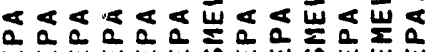

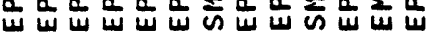

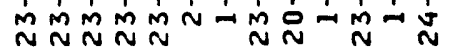

ํํำ

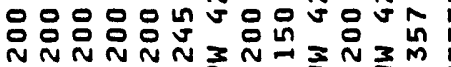

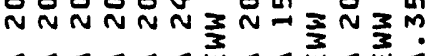

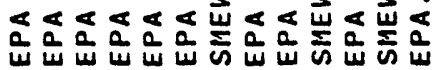

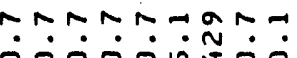

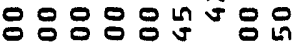

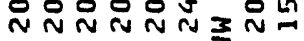

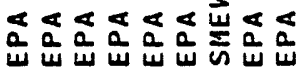
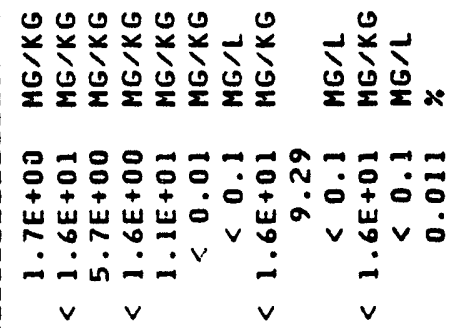

OU

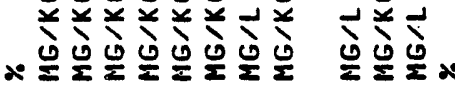

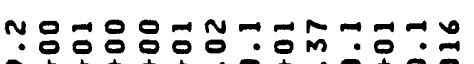

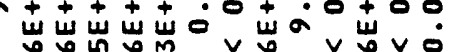
-

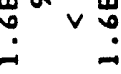

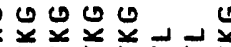

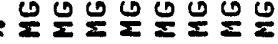
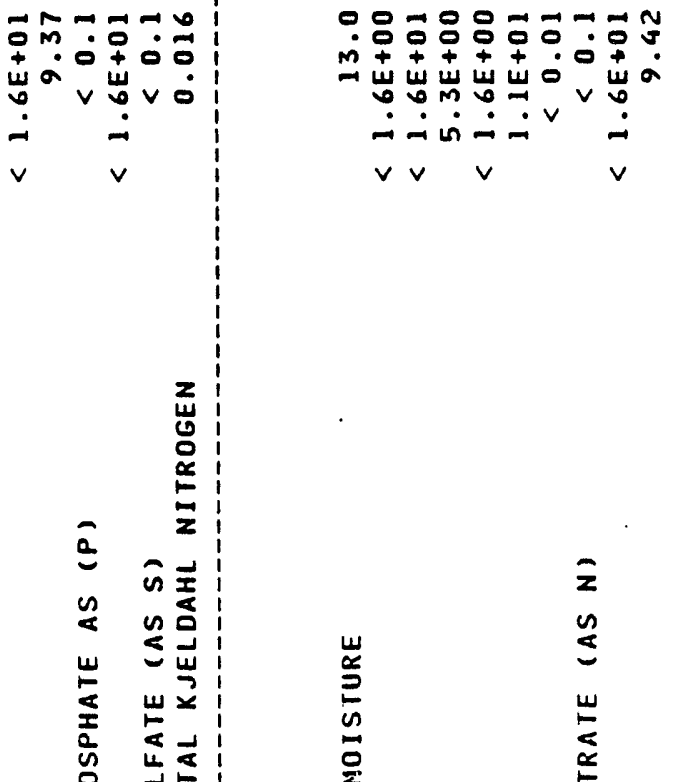

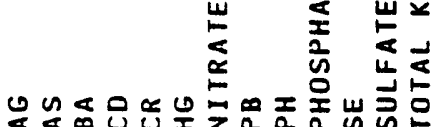
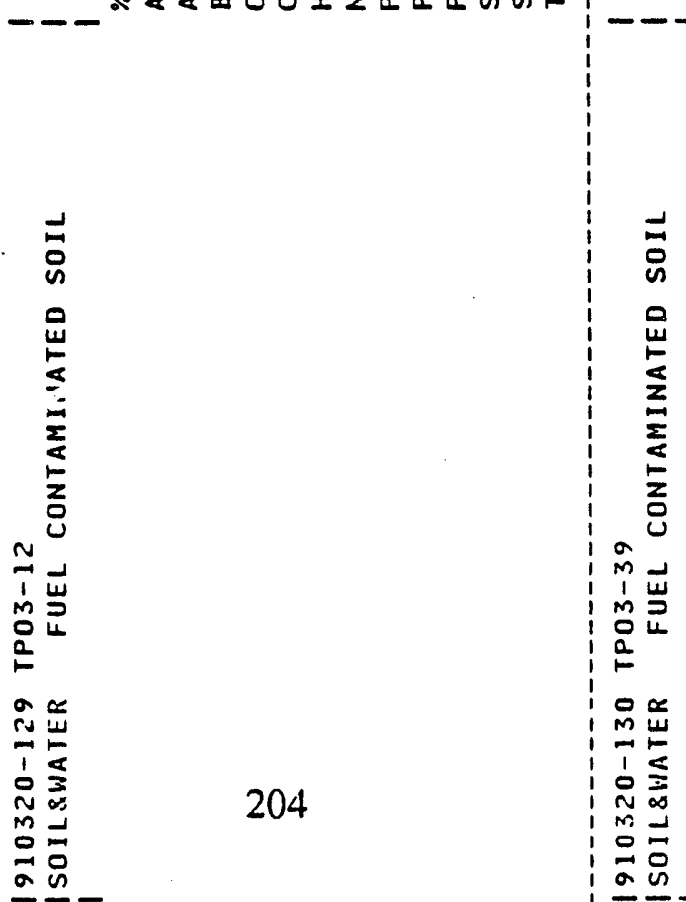

峞

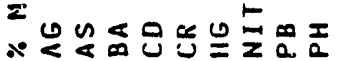




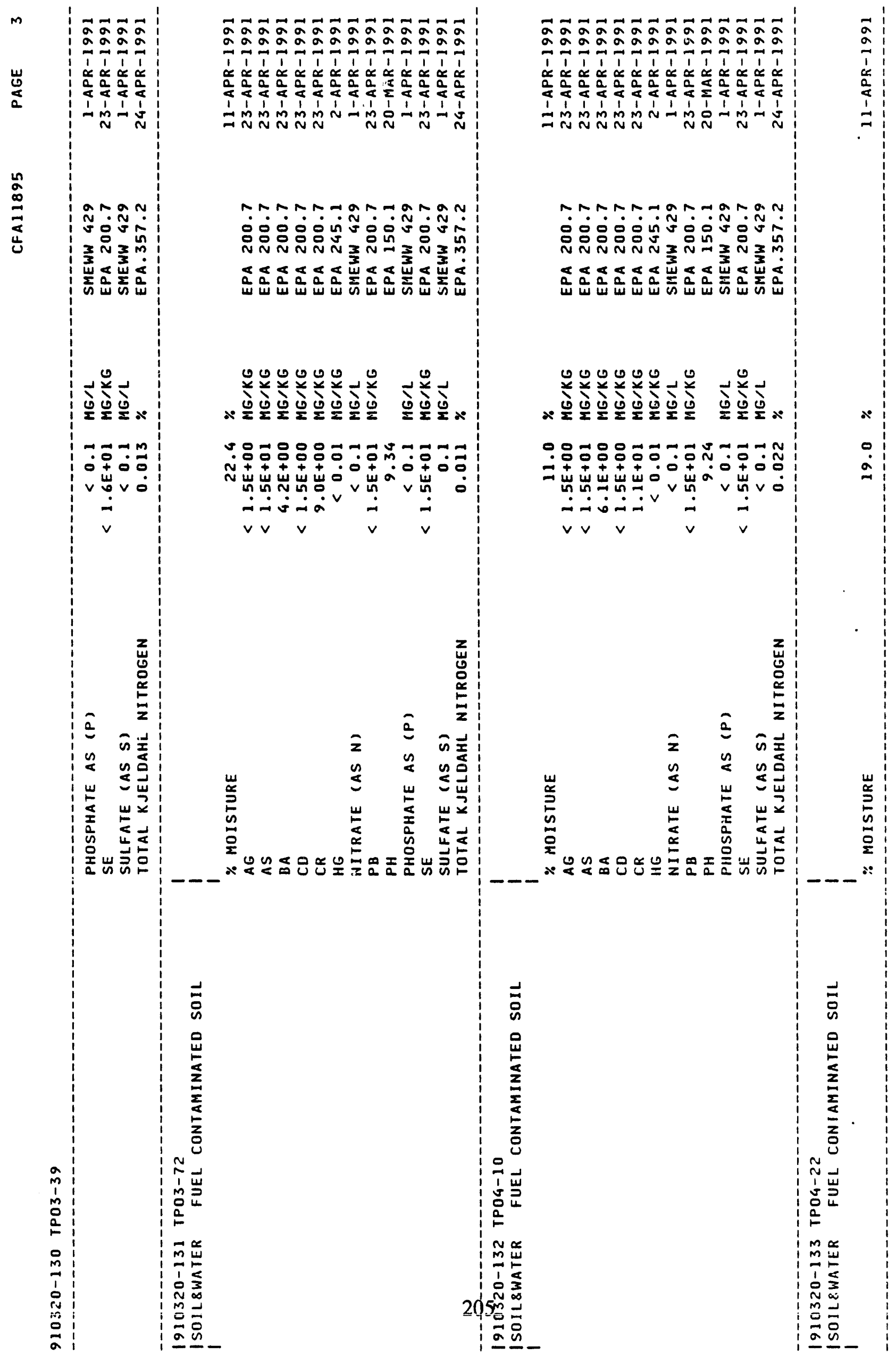




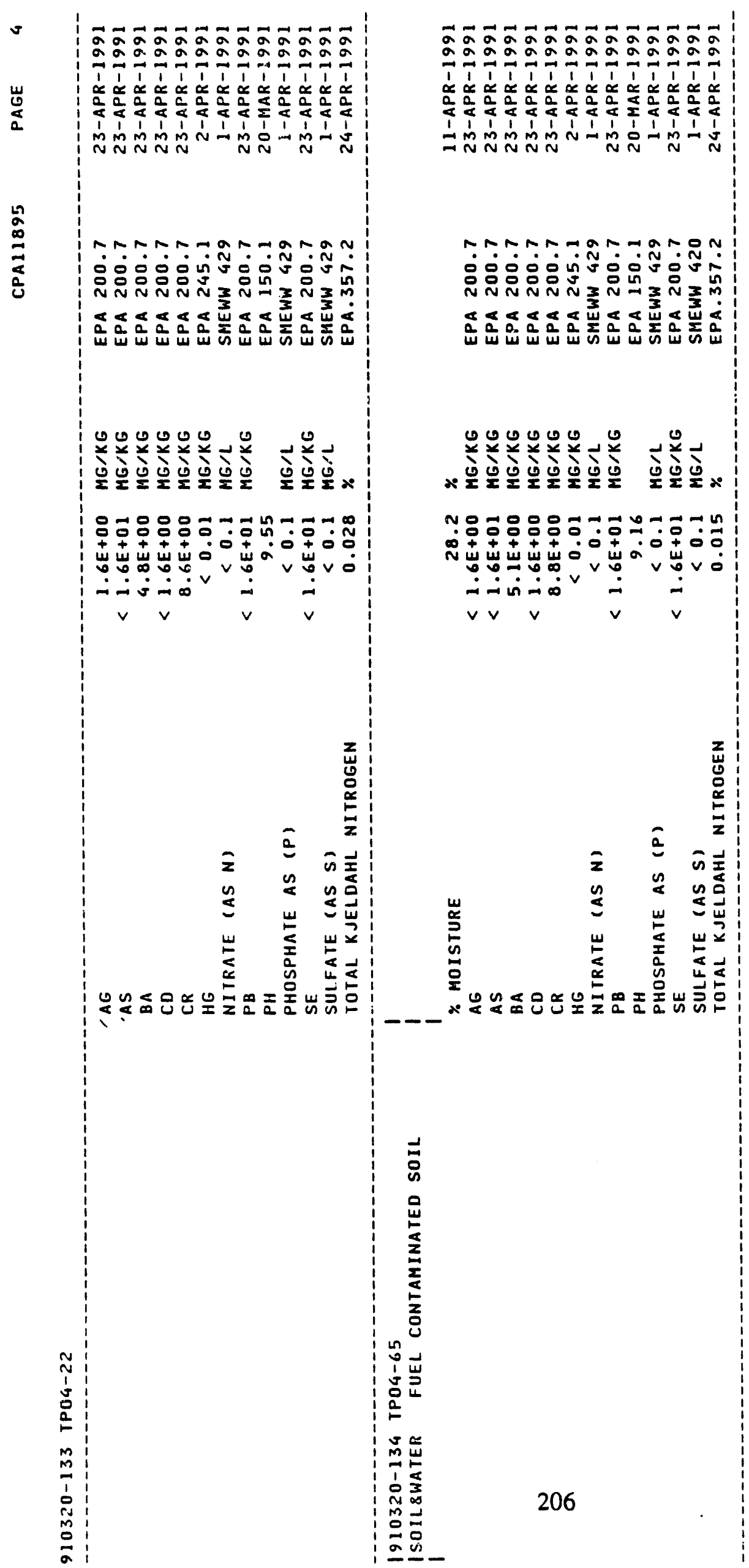




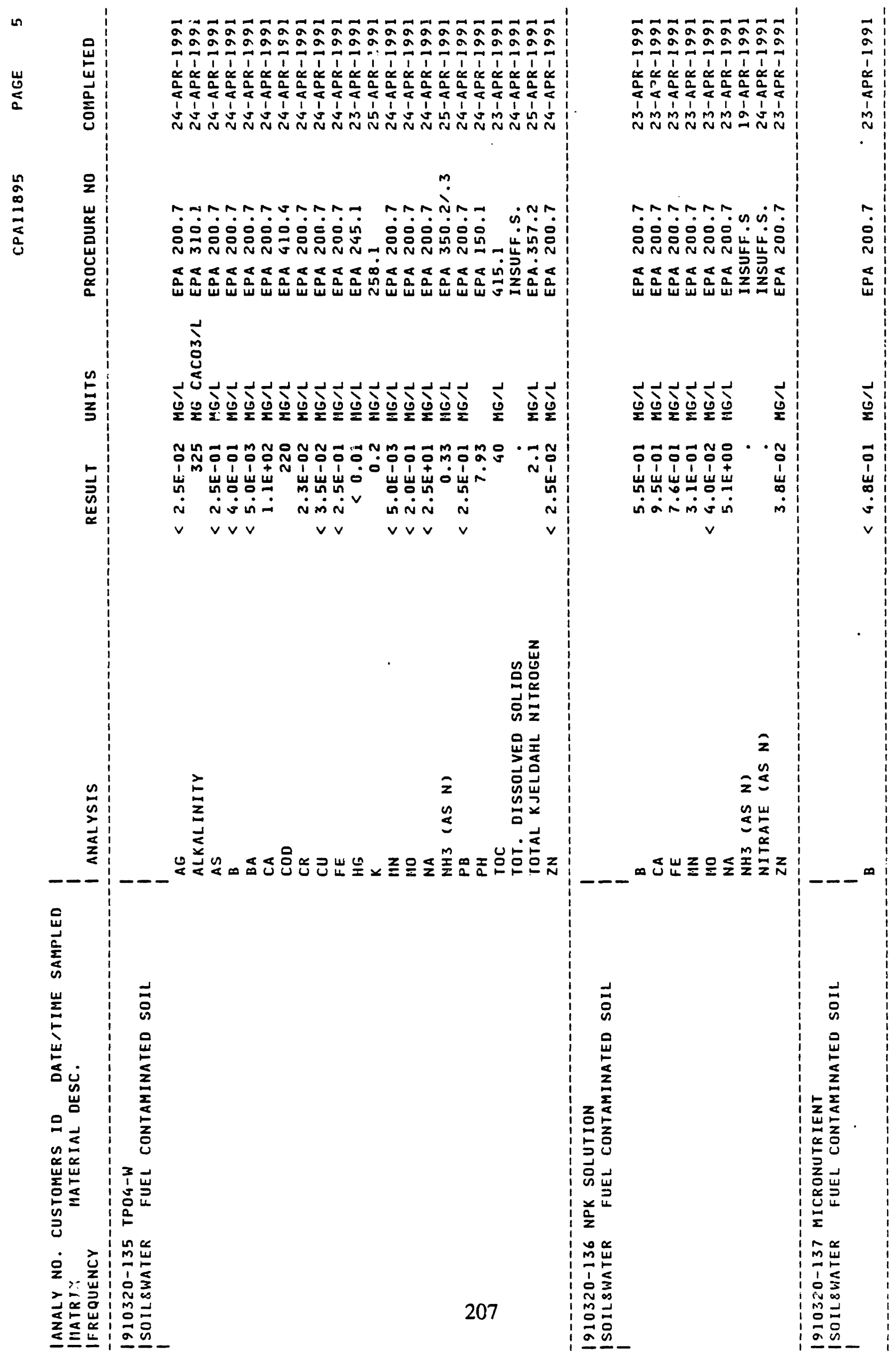




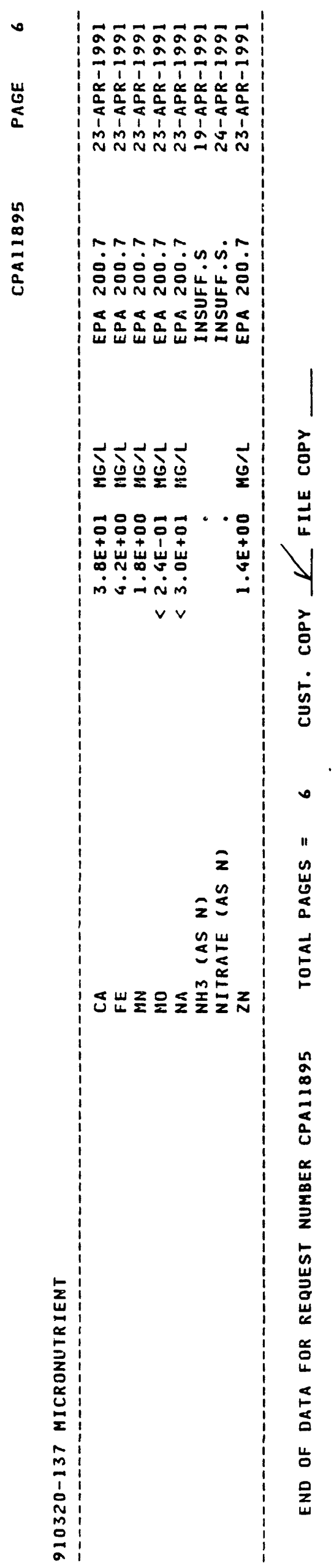




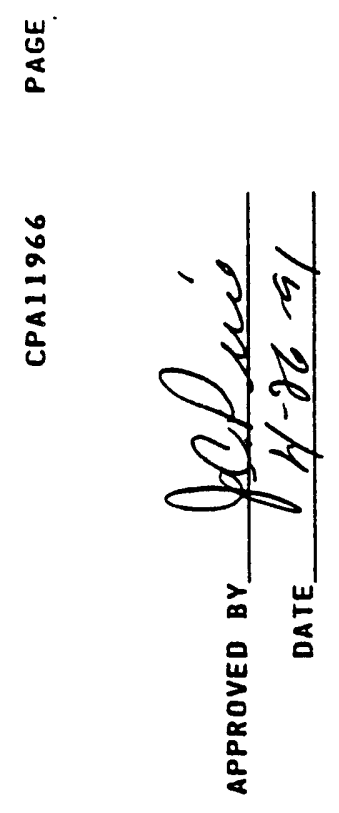

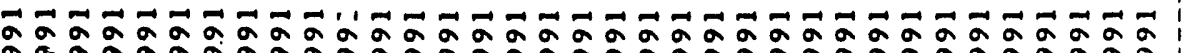

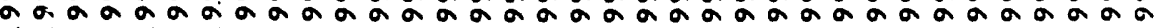

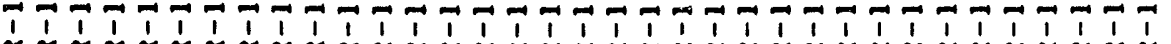

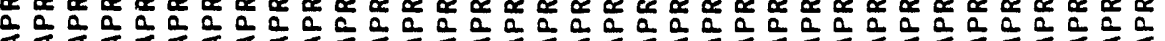

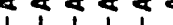
(4)

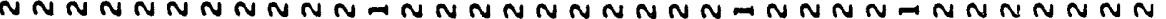

MNMNNNNNON NNN NNNNNNNGNMMONNNNMO

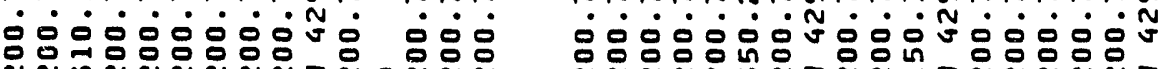

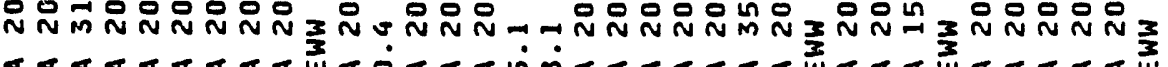

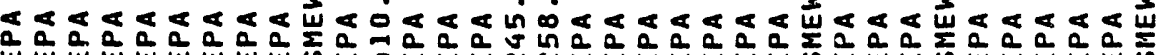

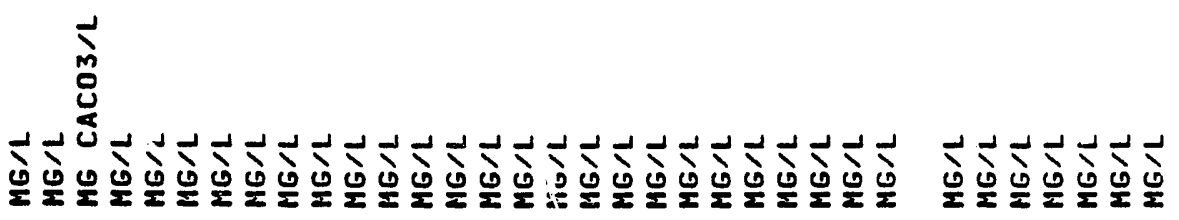

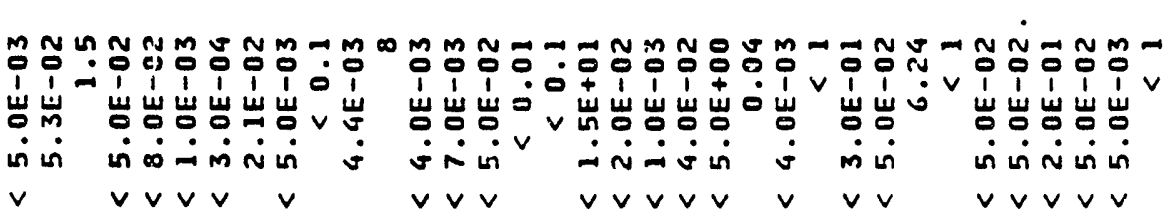

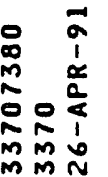




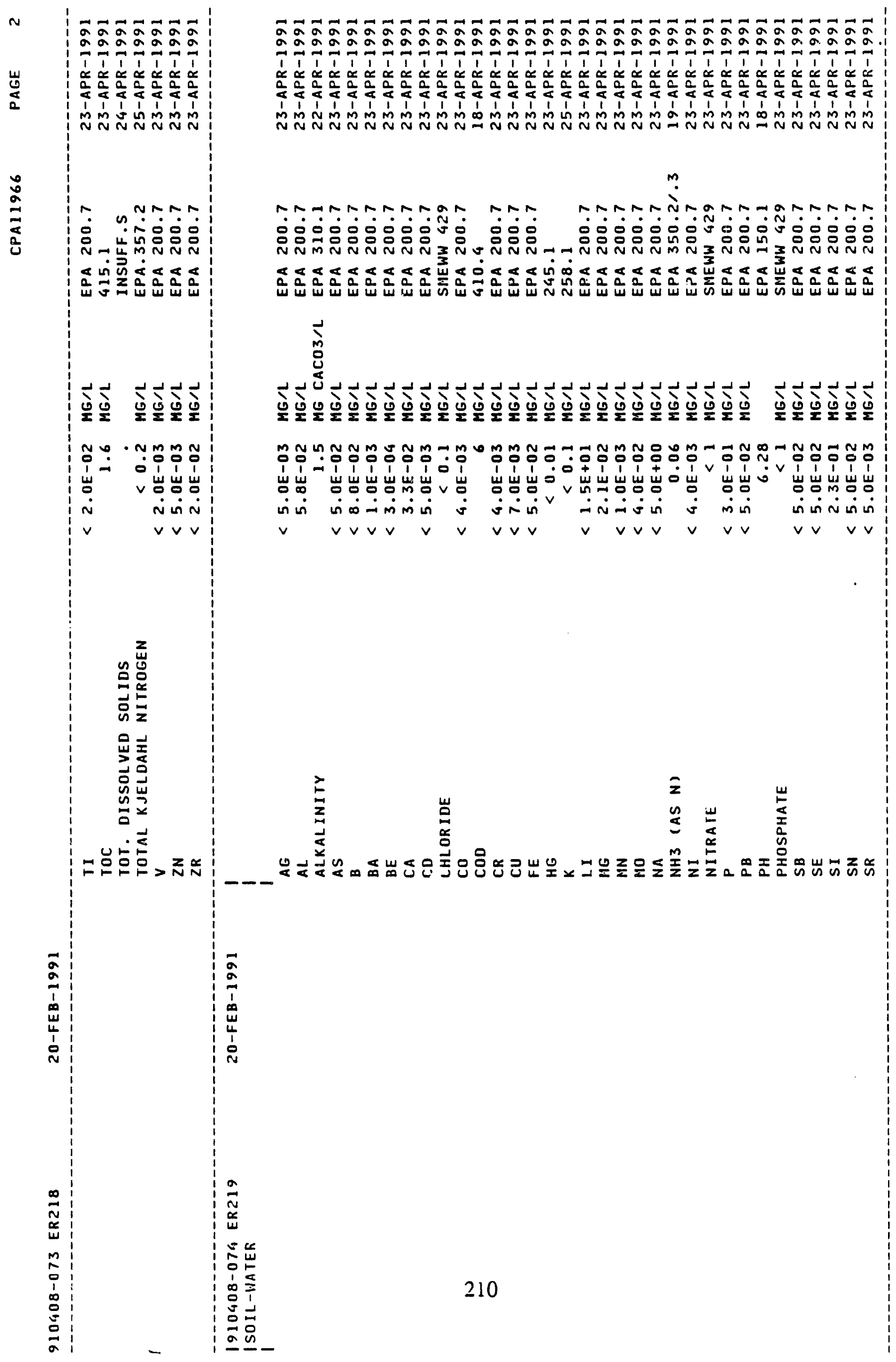




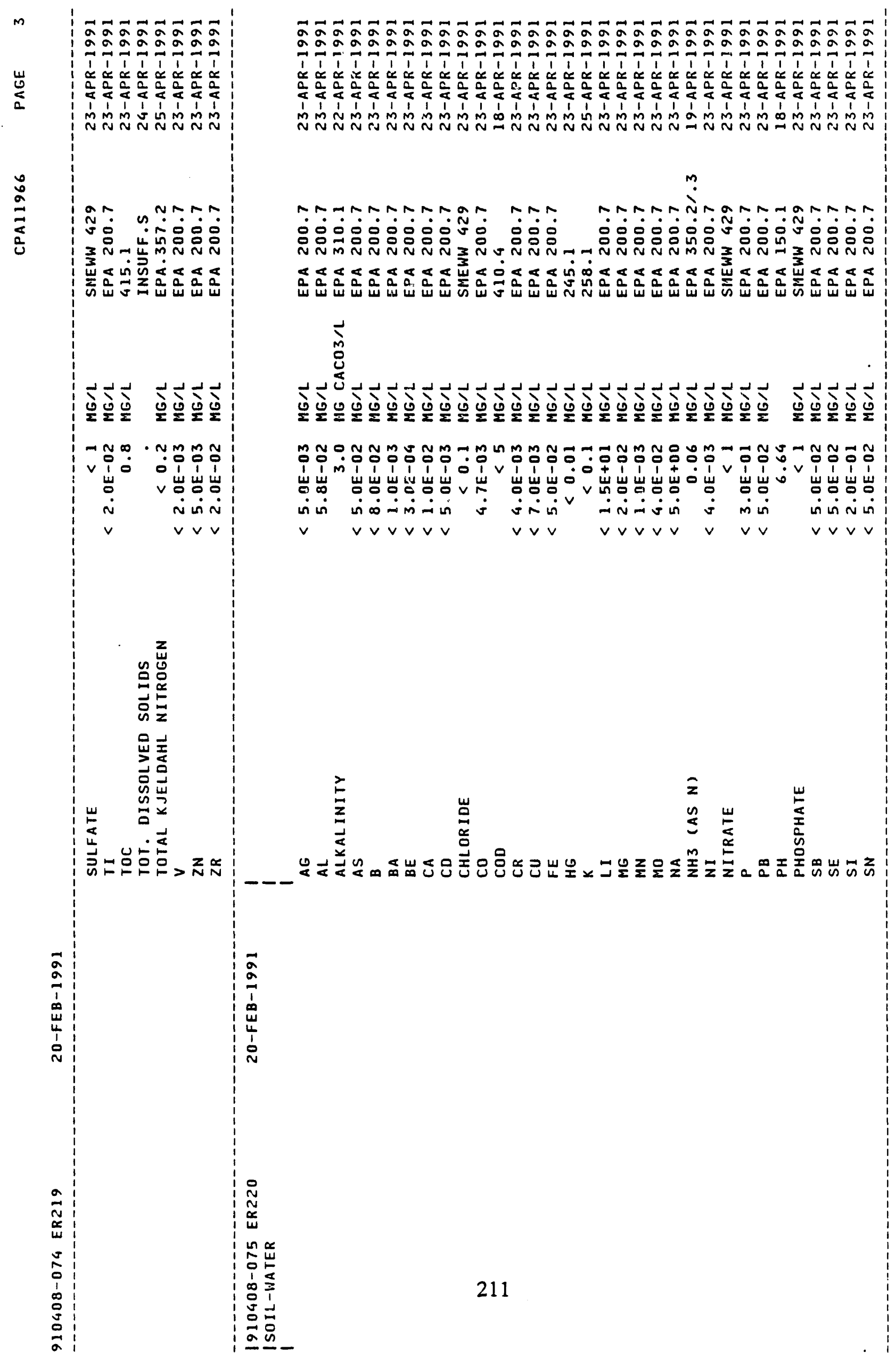




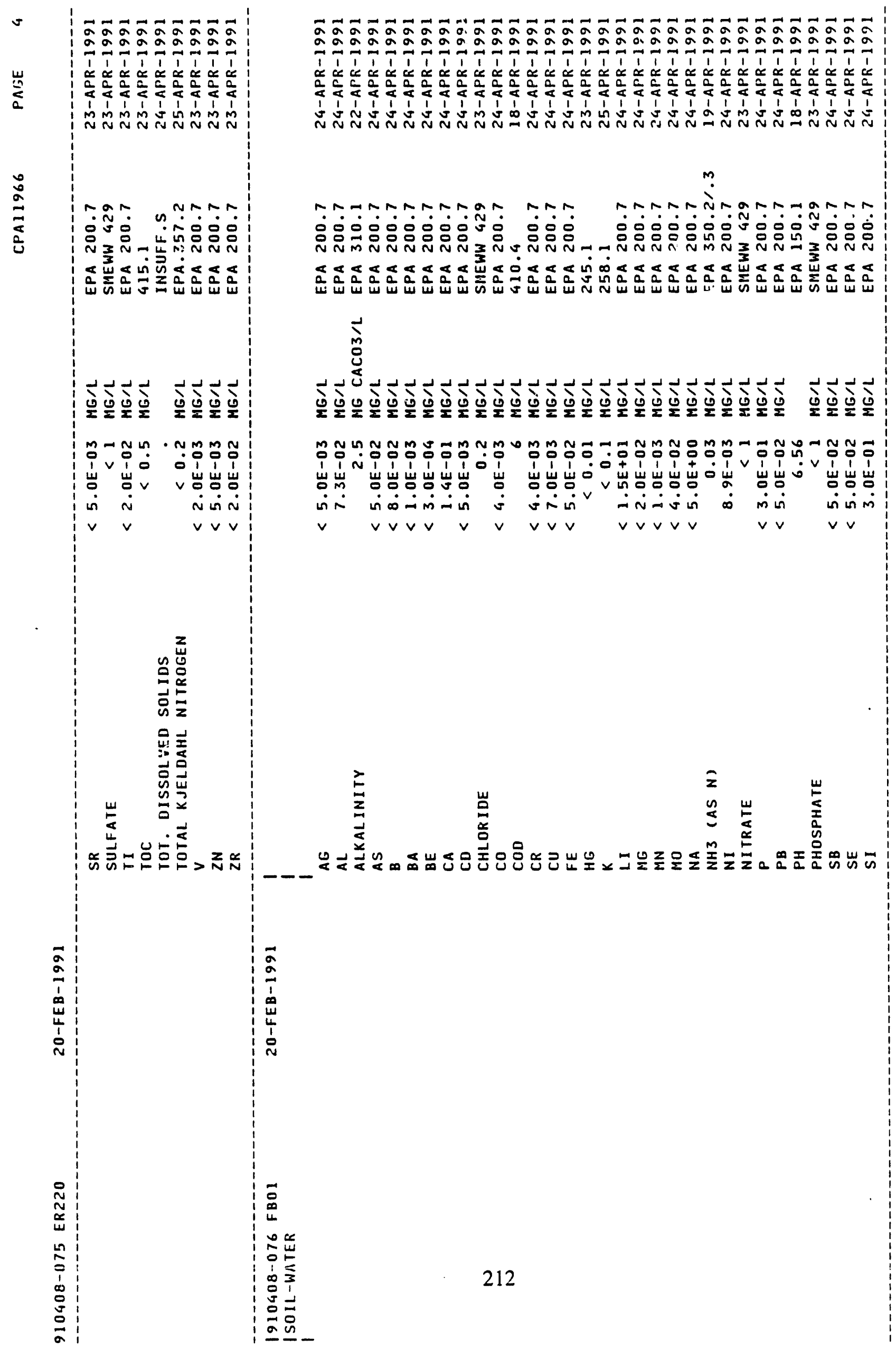




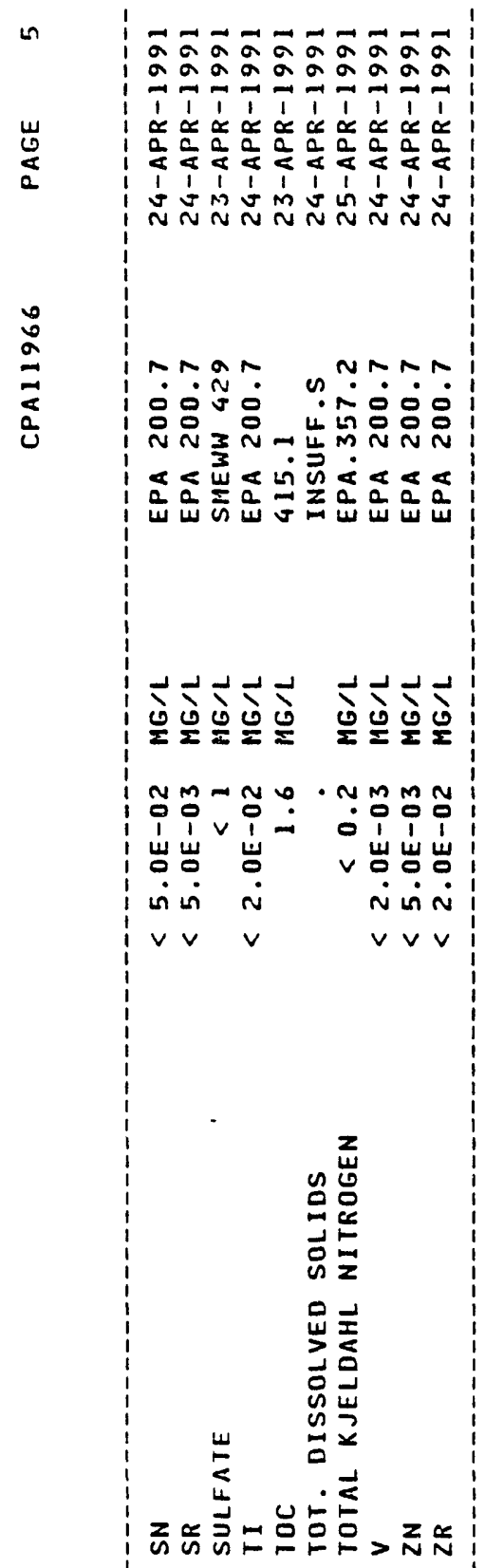

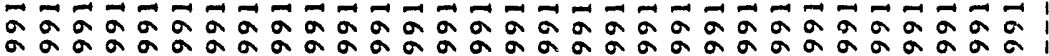

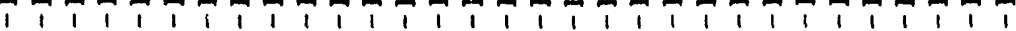

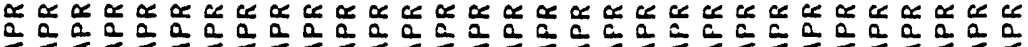

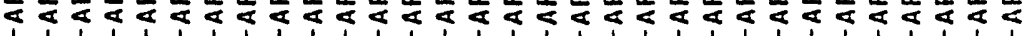

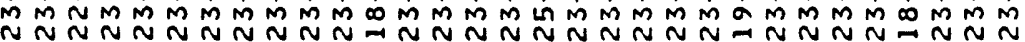

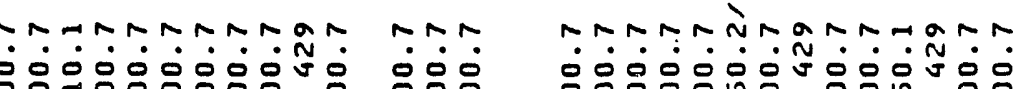

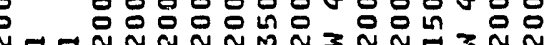

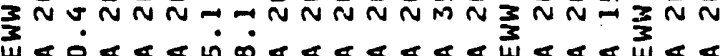

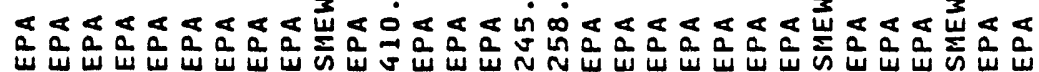

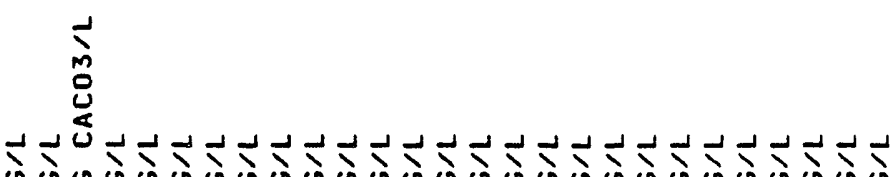

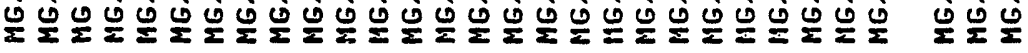

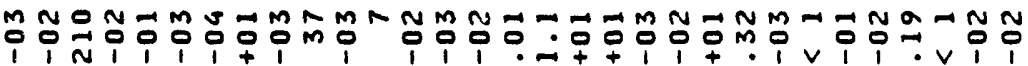

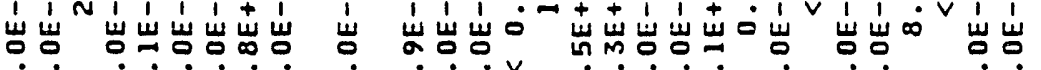

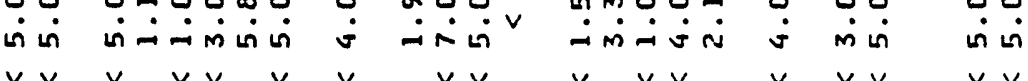
$\vee \vee \vee \vee v \vee v \vee v \vee v \vee v \vee v$

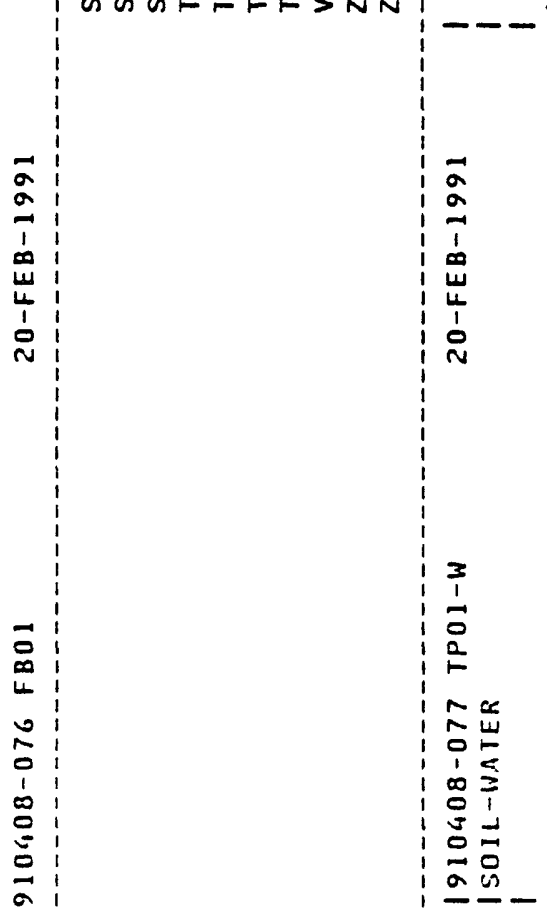




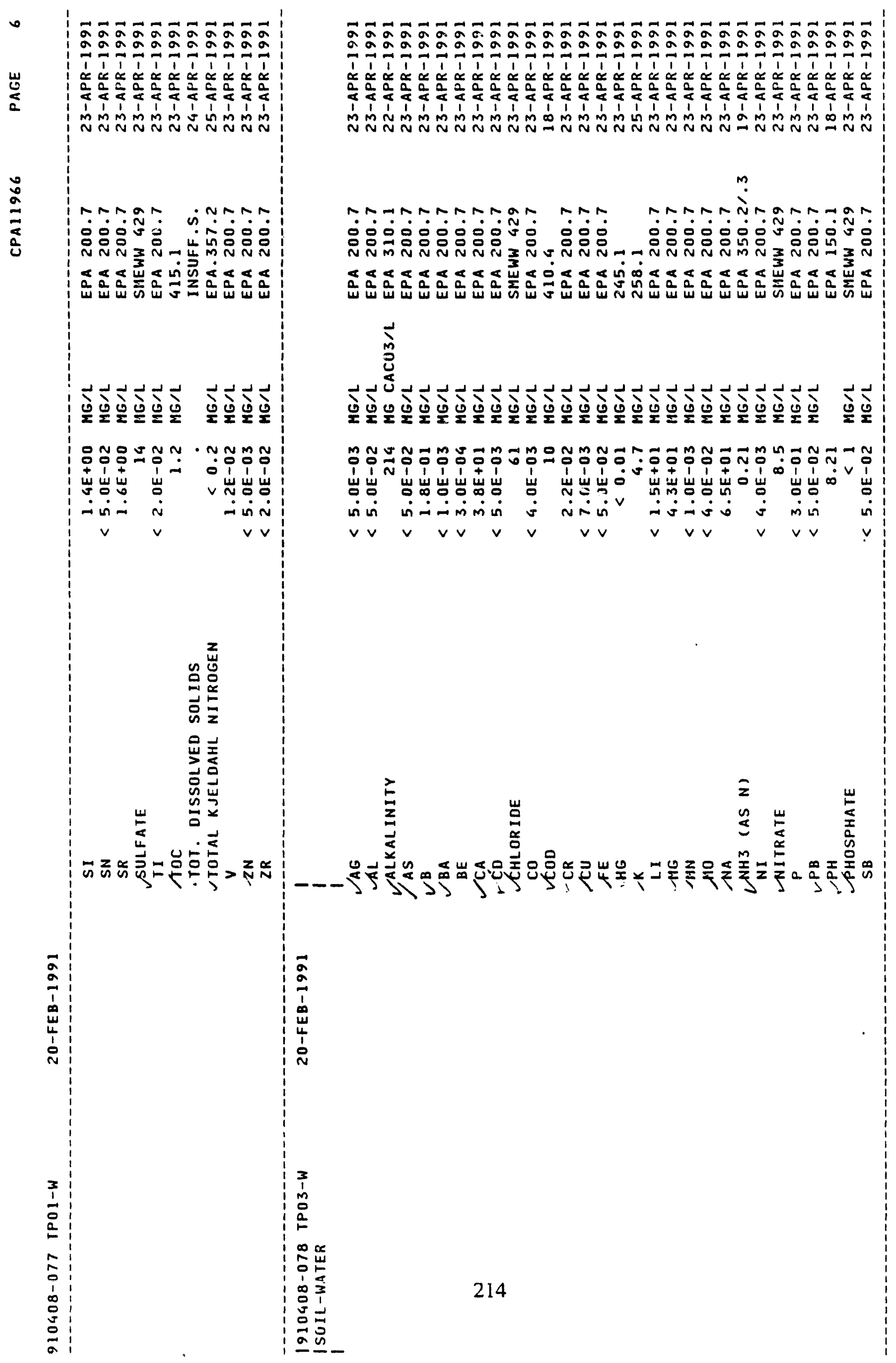




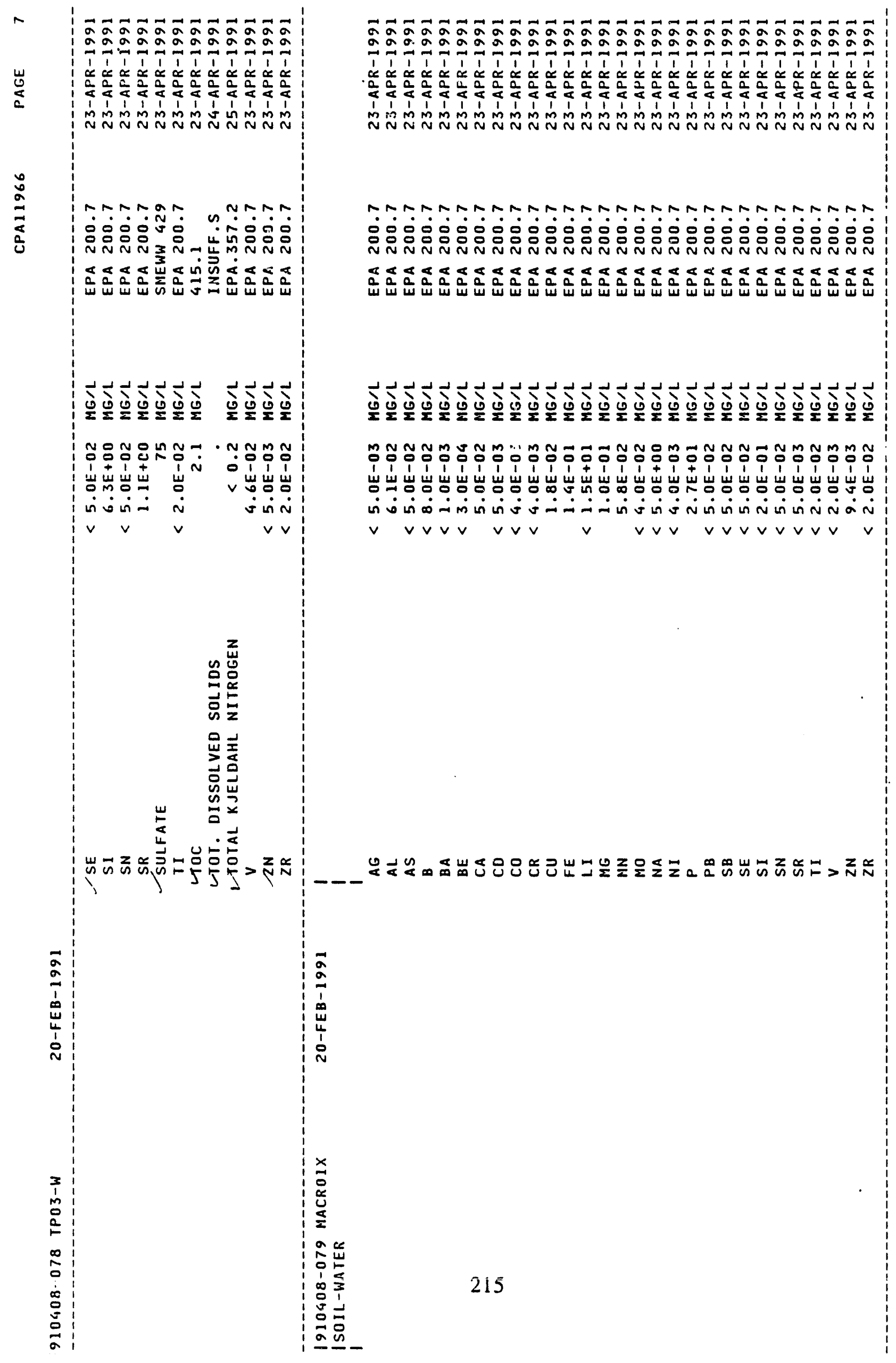




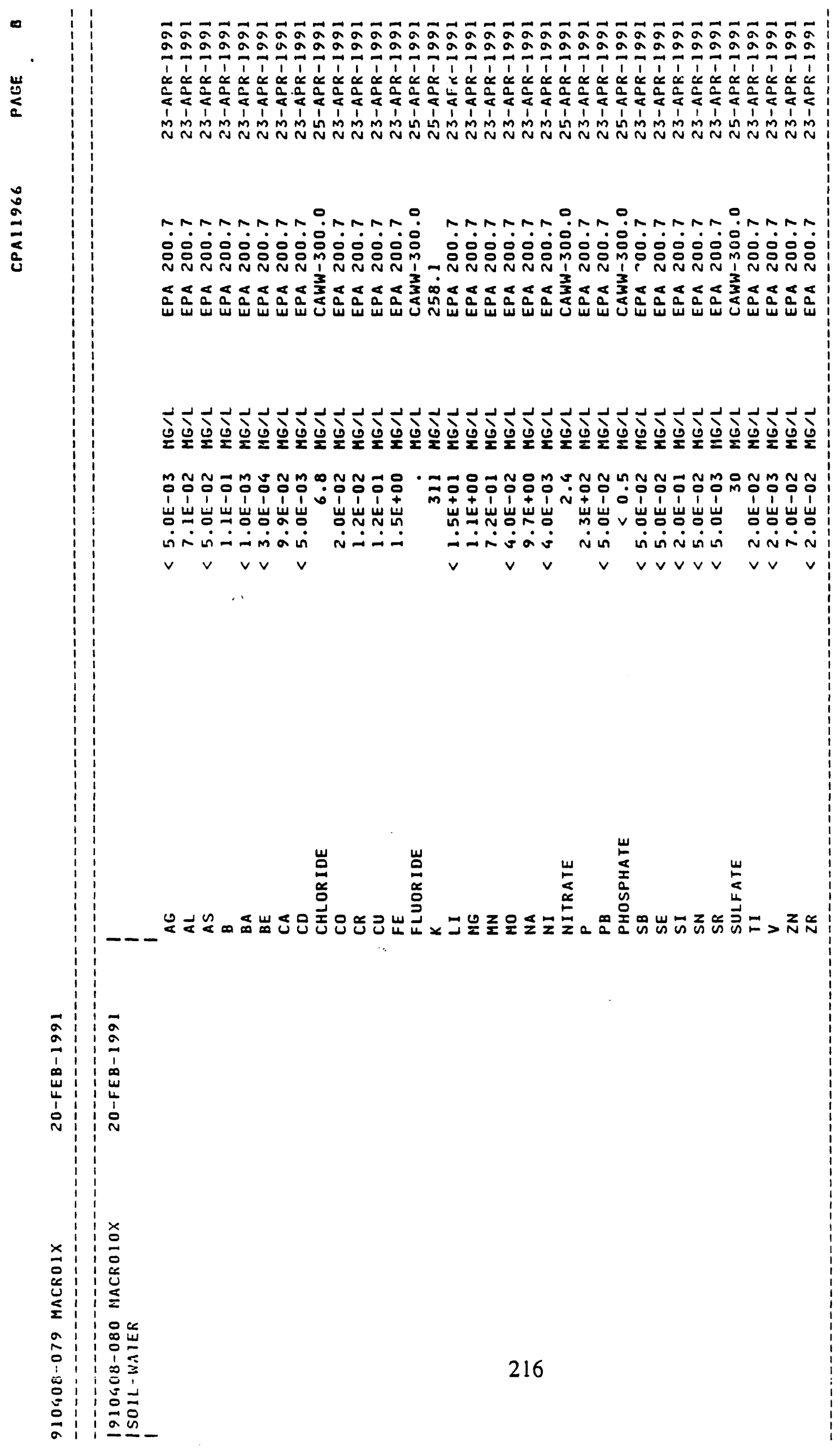




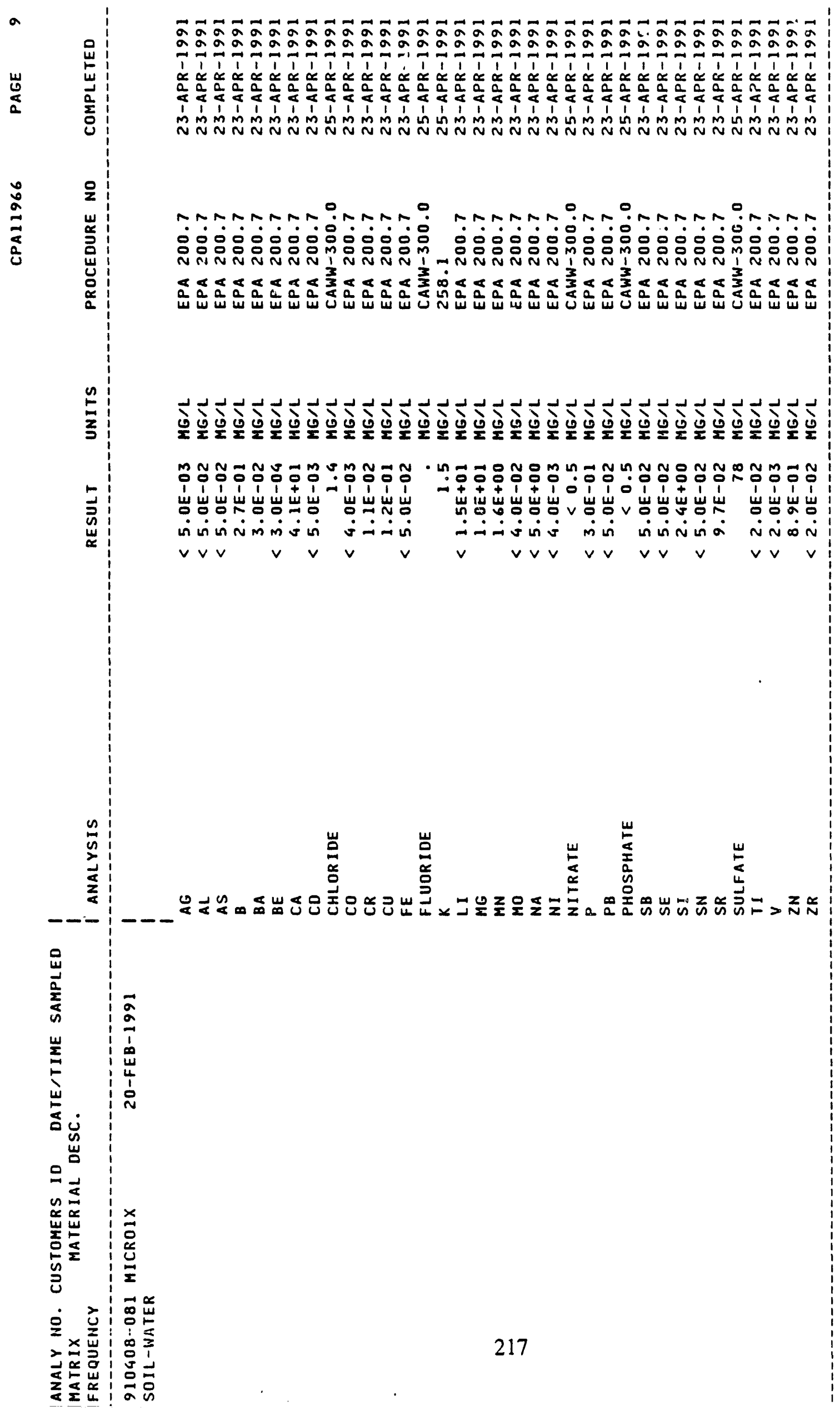




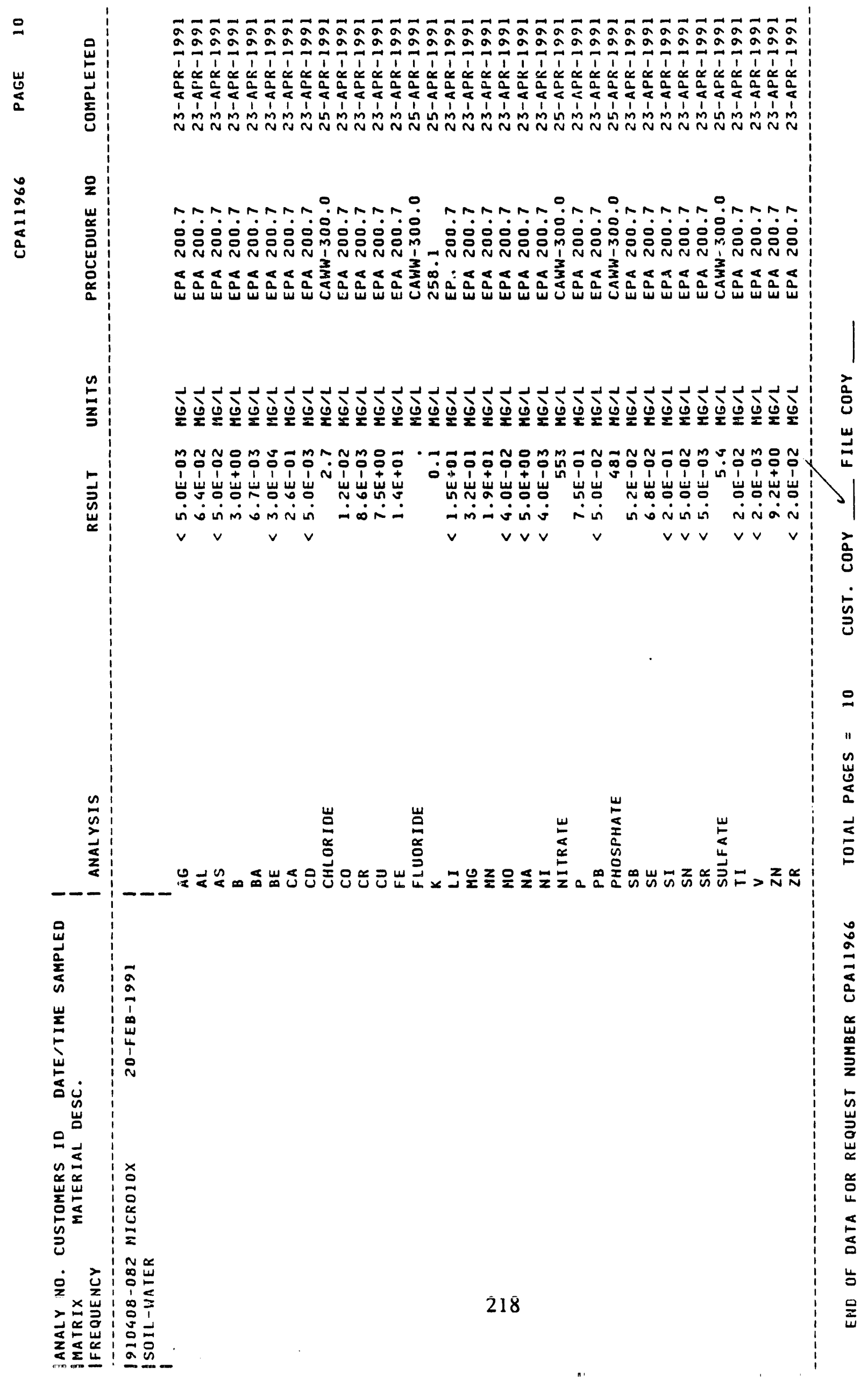




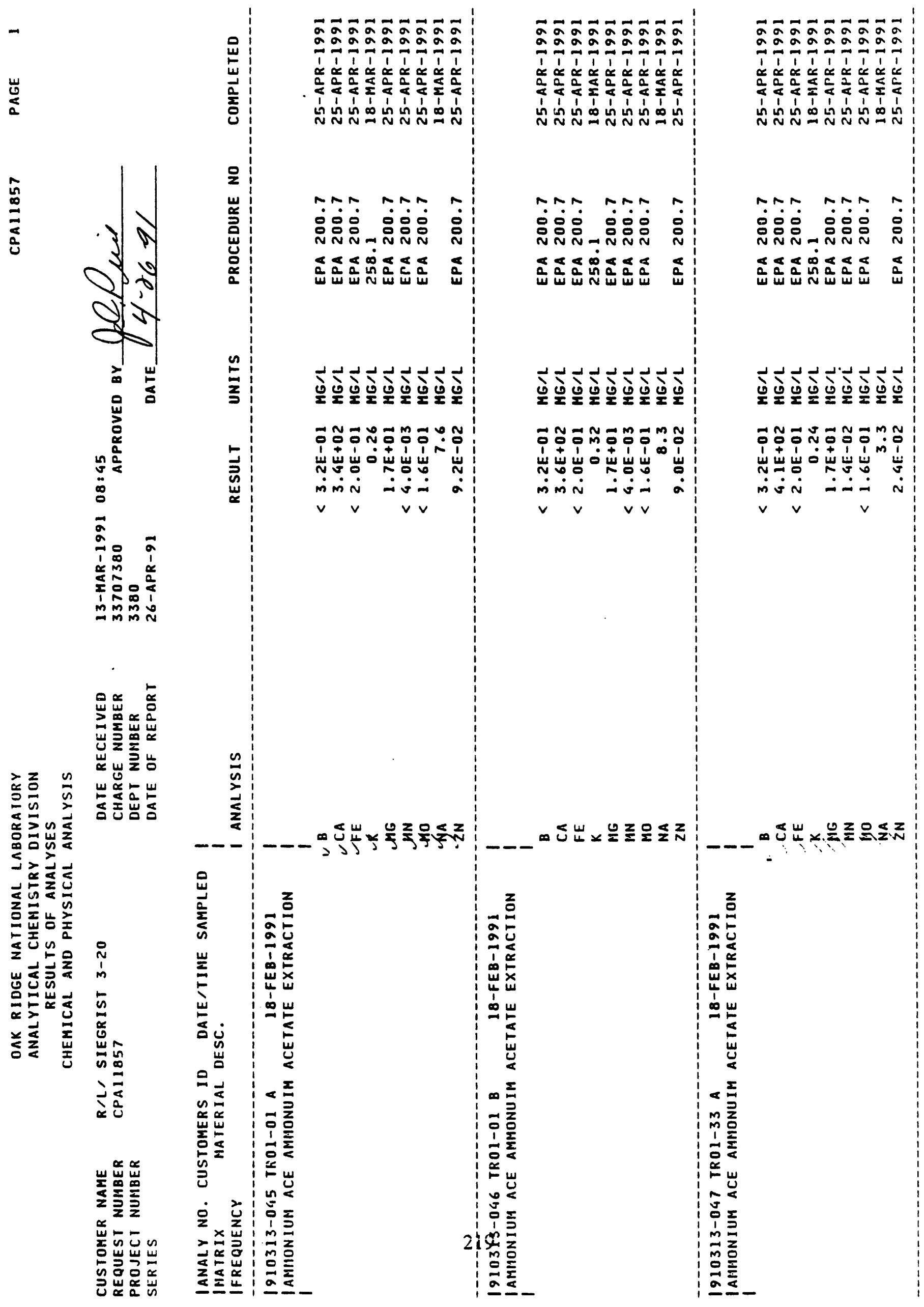




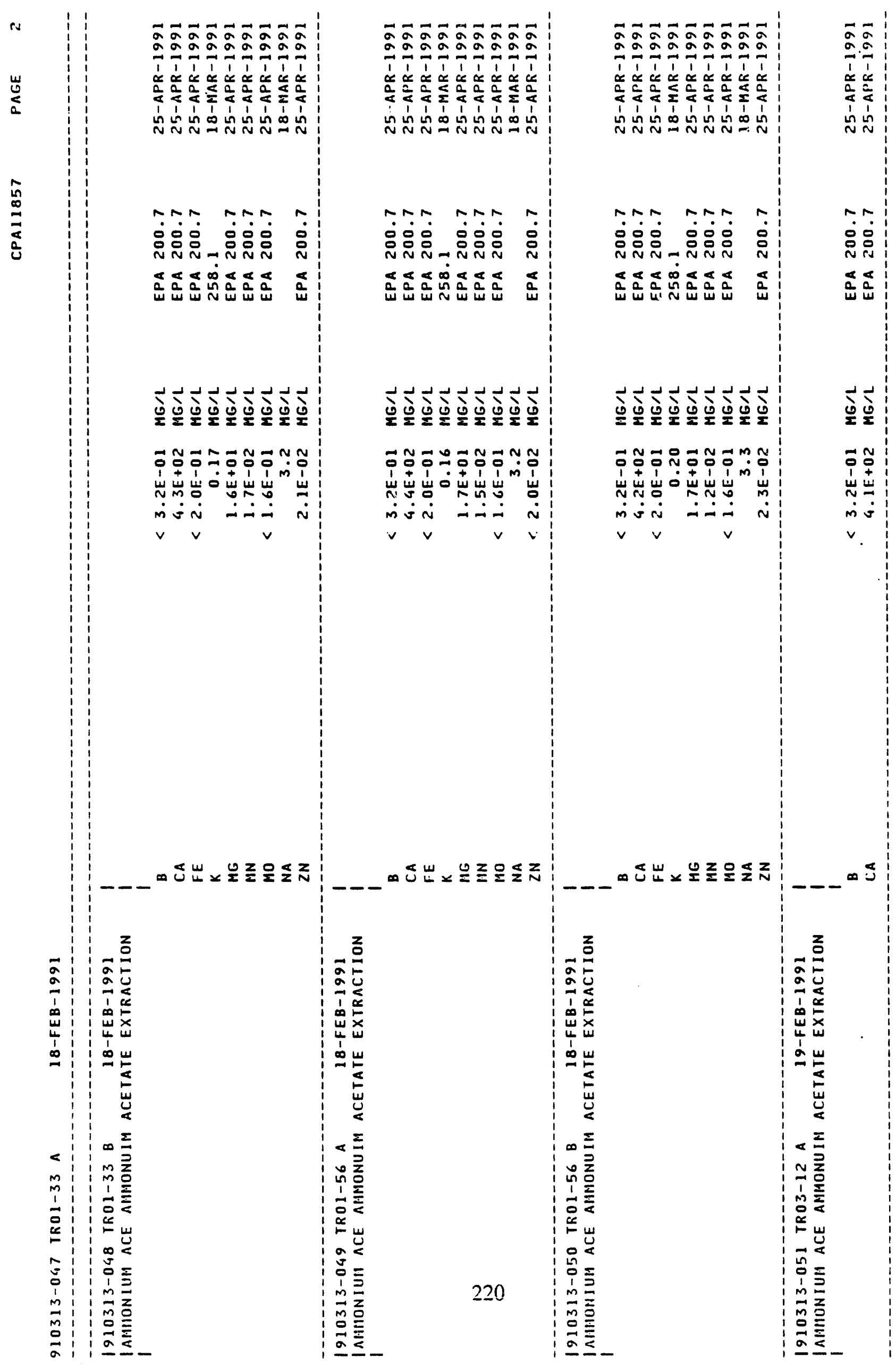




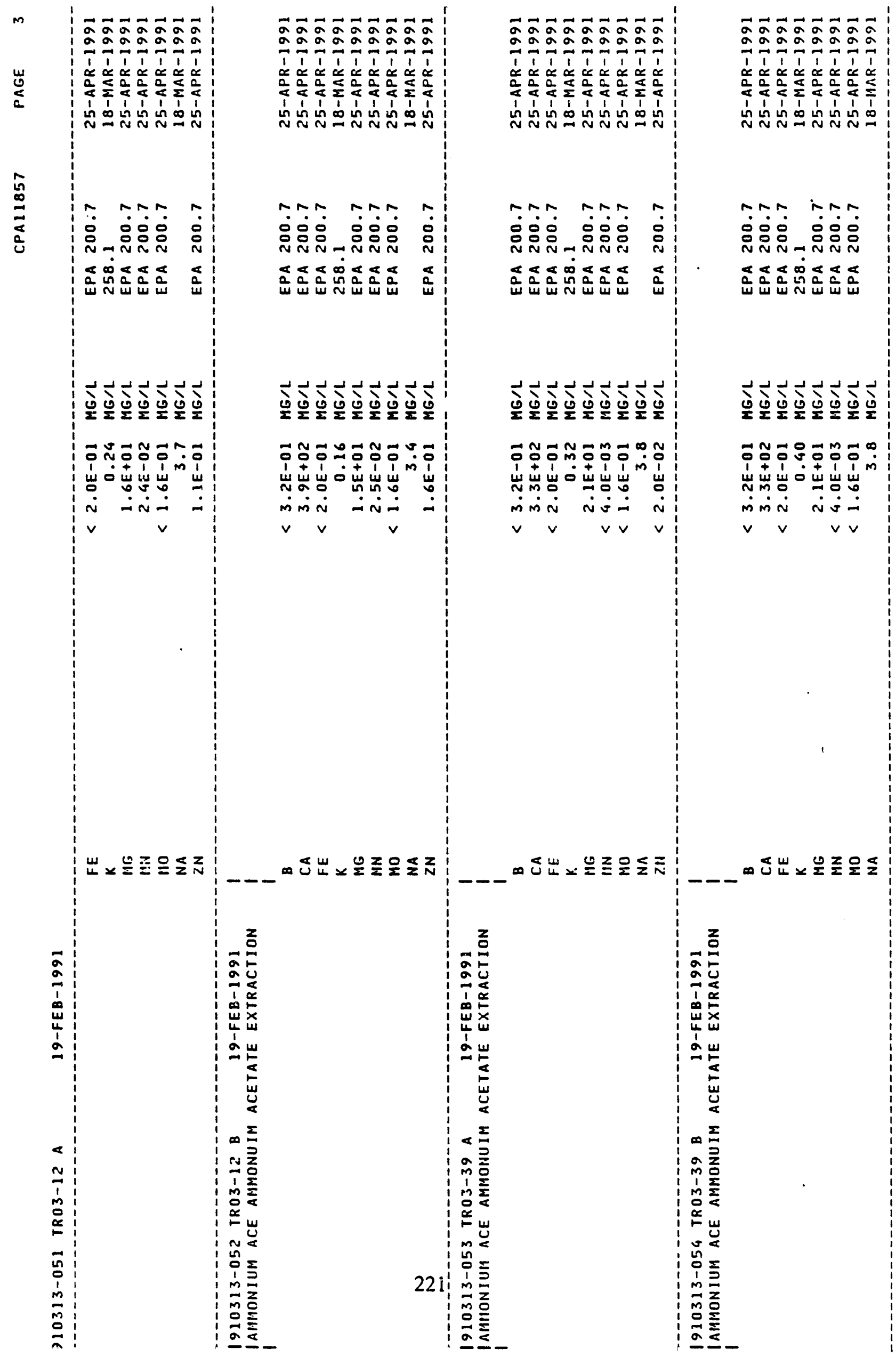




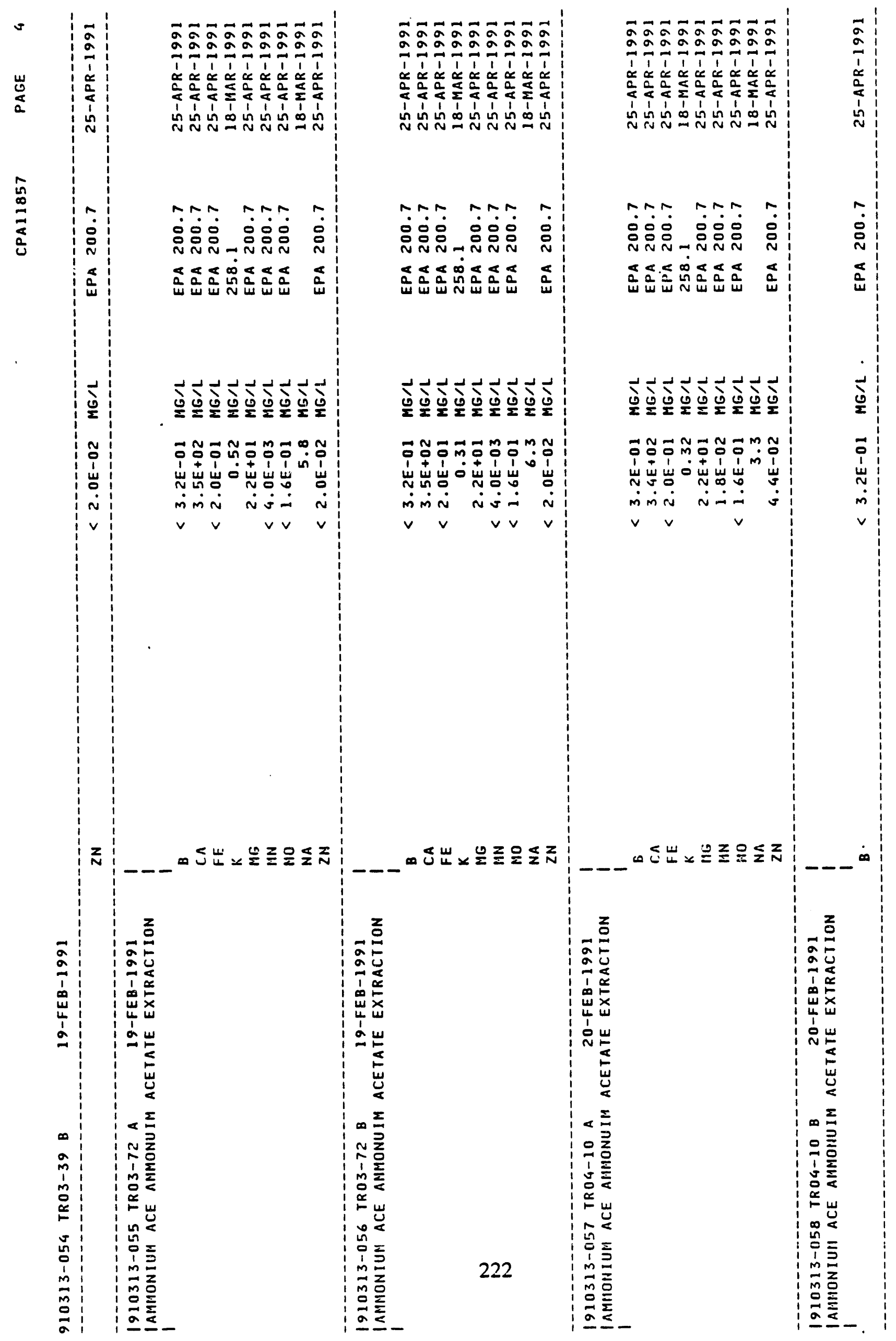




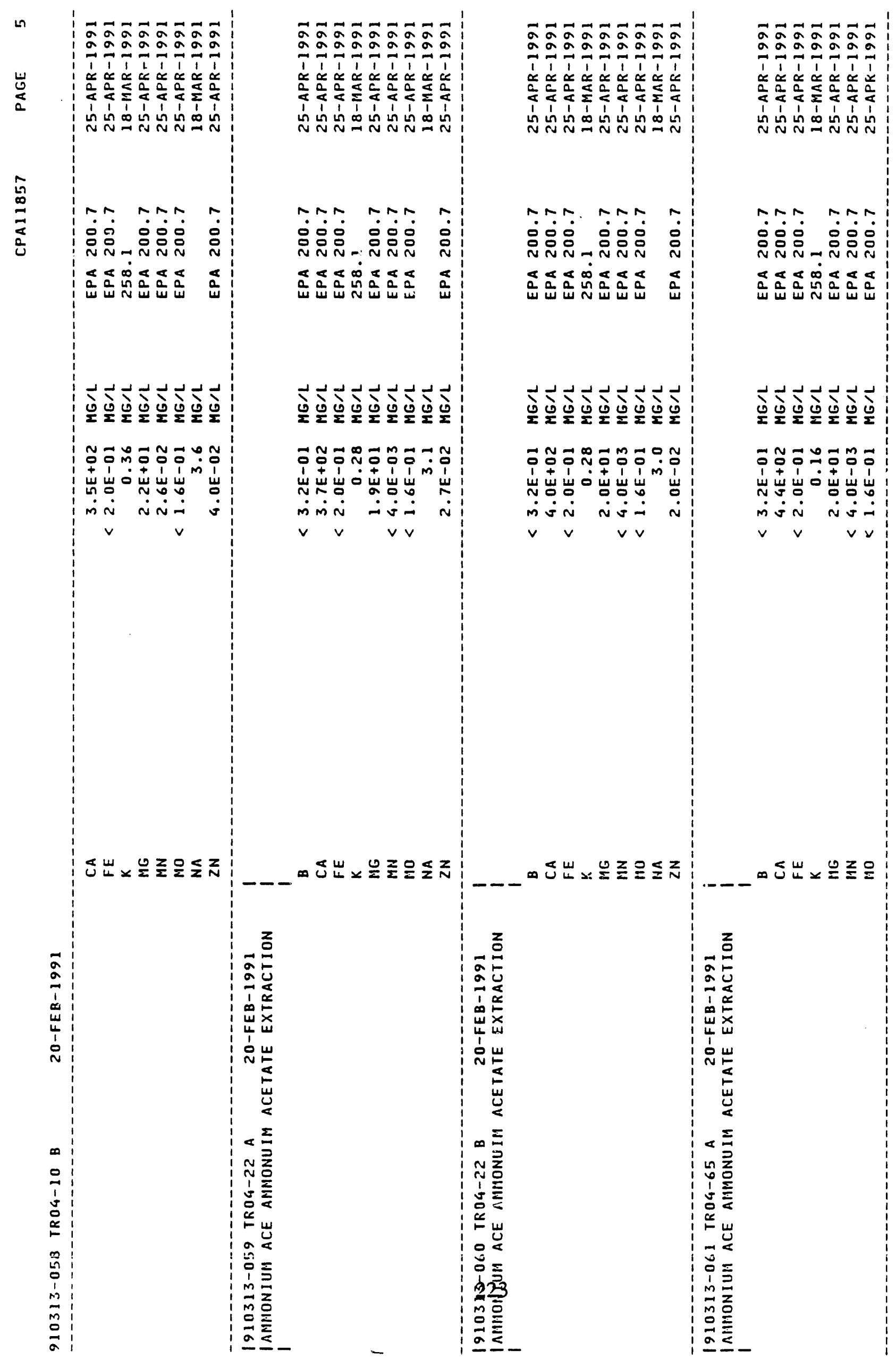




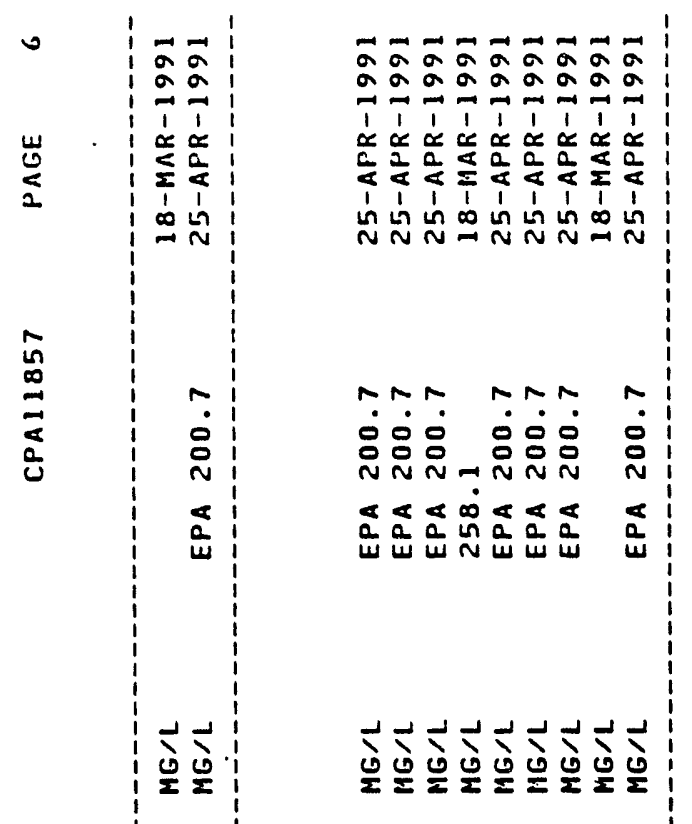

NN $n$ N

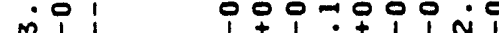

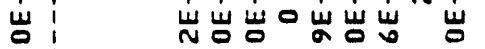
i $\dot{m} \dot{\sim} \dot{\sim} \dot{\sim} \dot{\sim}$ $v \vee v \vee v v$

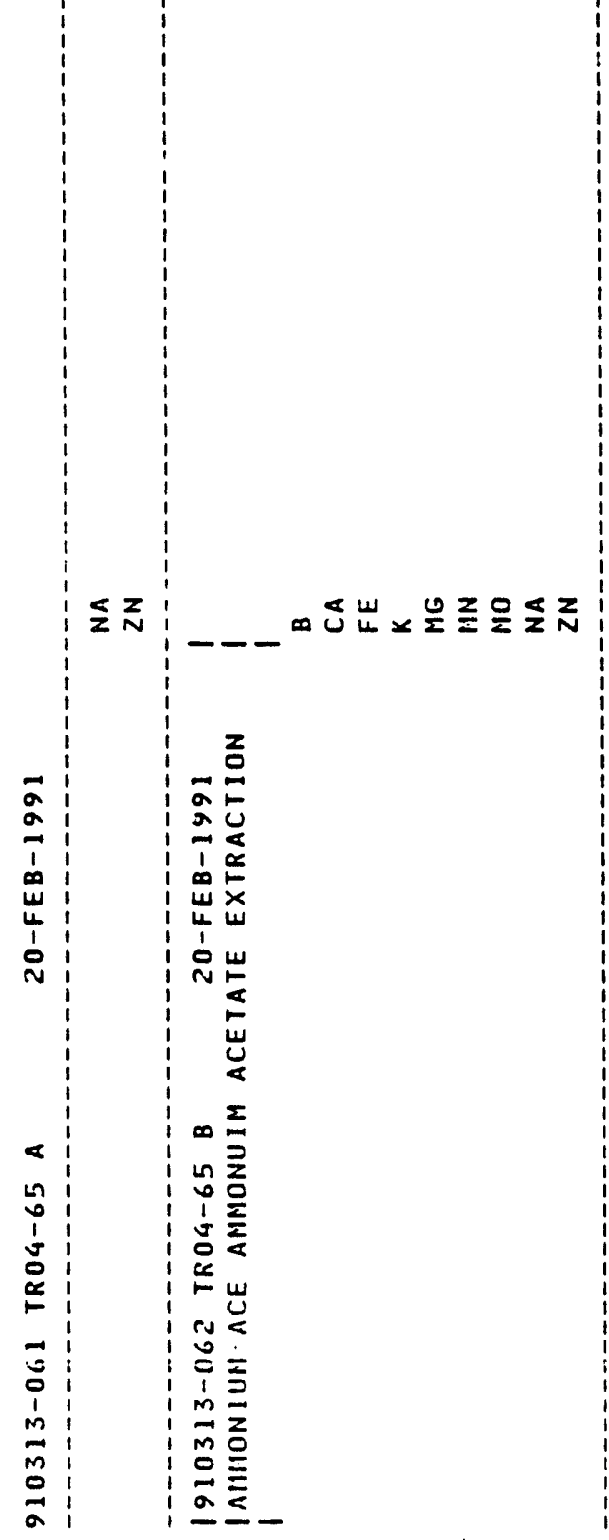




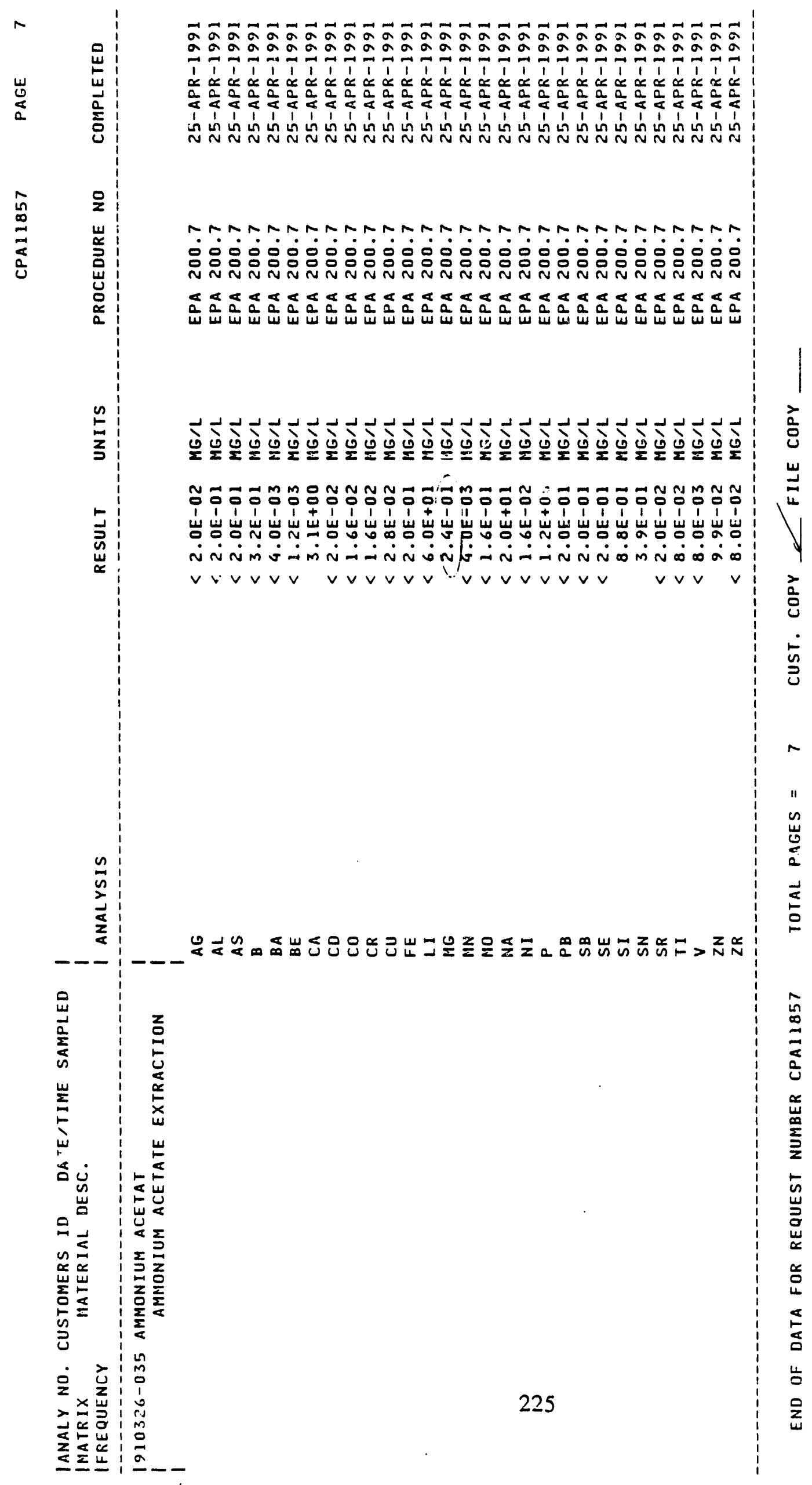


㟔
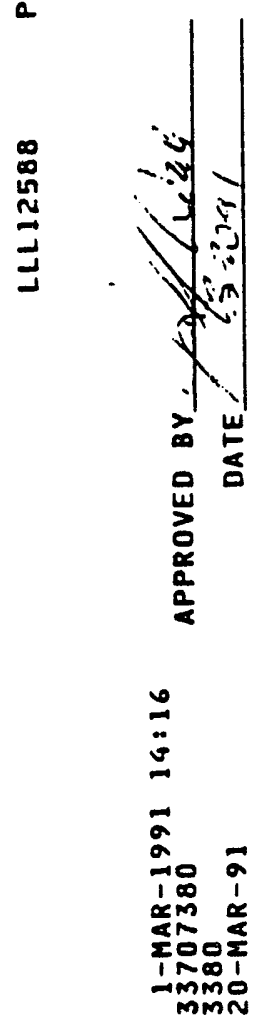

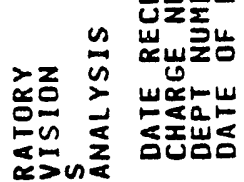

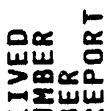

acó

品司

을

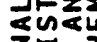

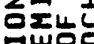

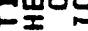

这里

wड़े

进数

드눈

«政

링

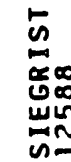

.

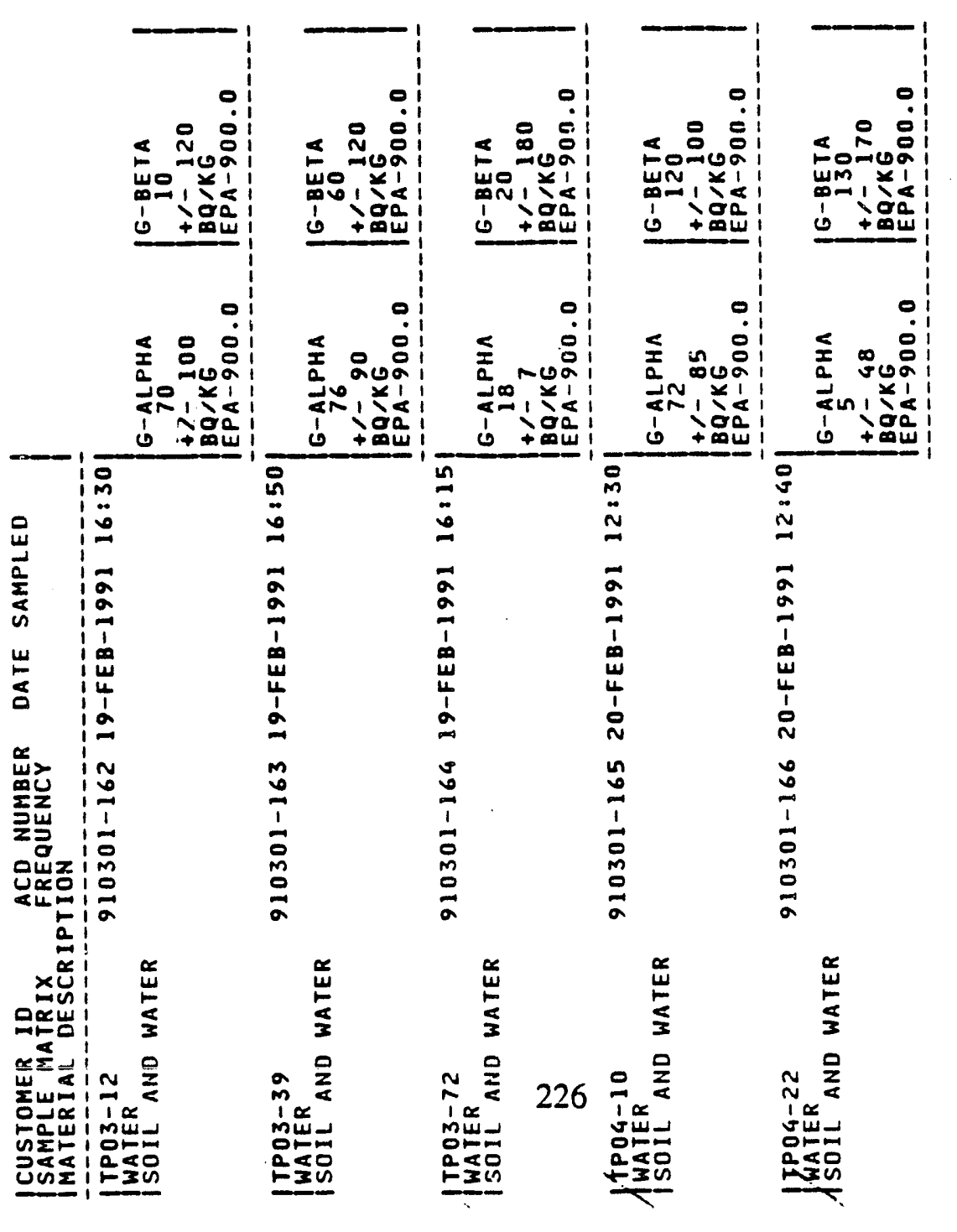




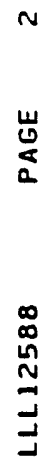

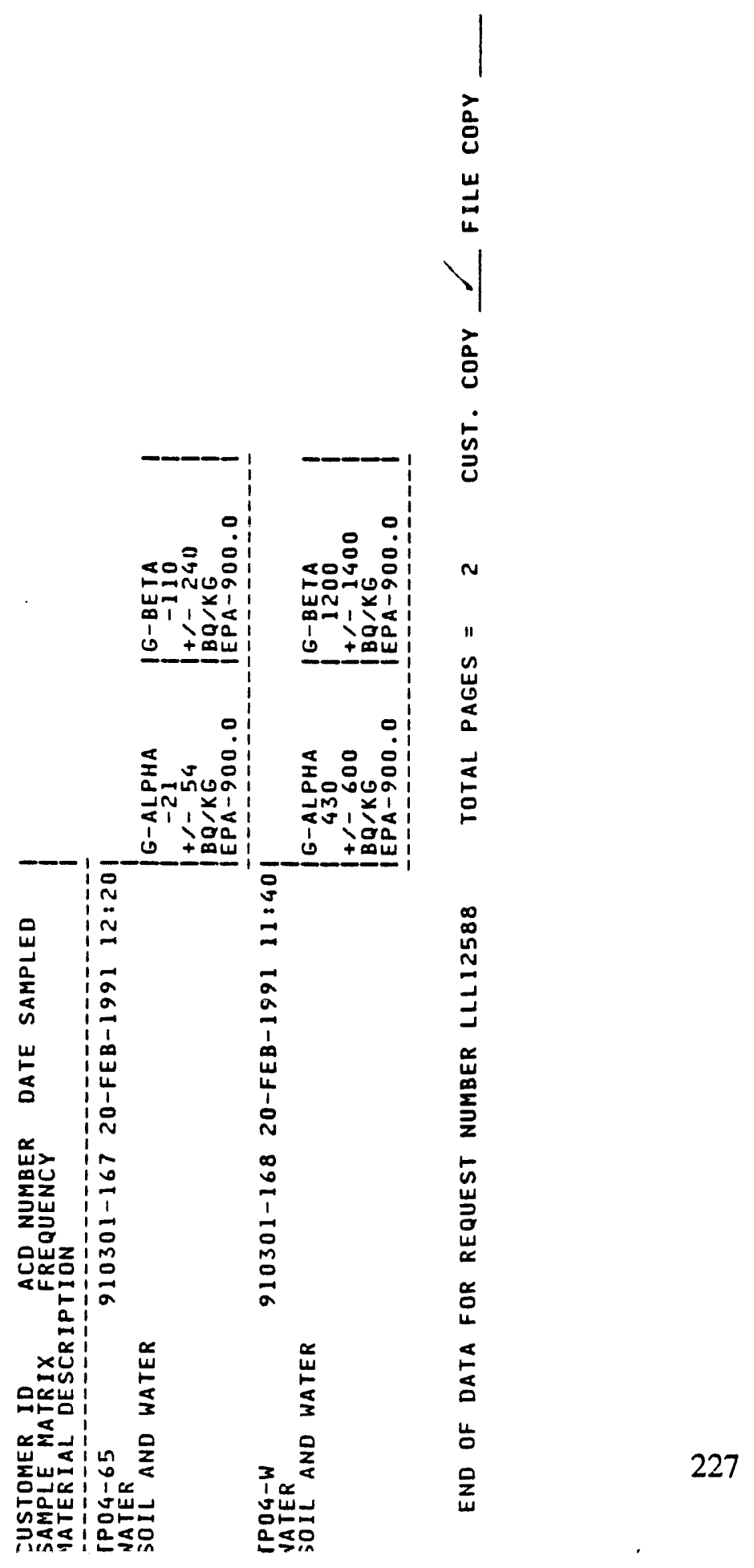




\section{INTERNAL DISTRIBUTION}

\begin{tabular}{ll}
1. & \\
2. & L. D. Bates \\
3. & B. A. Bervin \\
4. & C. H. Brown, Jr. \\
5. & A. G. Croft \\
6. & J. H. Cushman \\
7. & T. L. Donaldson \\
8. & M. P. Farrell \\
9. & D. E. Fowler \\
10. & W. Fulkerson \\
11. & C. W. Gehrs \\
12. & R. G. Genung \\
13. & S. E. Herbes \\
$14-23$. & S. G. Hildebrand \\
24. & R. L. Jolley \\
25. & A. V. Palumbo \\
26. & D. A. Pickering \\
27. & M. E. Reeves \\
28. & D. E. Reichle \\
$29-38$. & D. S. Shriner \\
39. & R. L. Siegrist \\
40. & S. H. Stow \\
41. & R. I. Van Hook \\
42. & J. F. Walker, Jr. \\
$43-57$. & Central Research Library \\
$58-59$. & ESD Library \\
60. & Laboratory Records Department \\
61. & Laboratory Records Department-RC \\
62. & Laboratory Protection Division \\
63. & ORNL Patent Office \\
& ORNL Public Affairs Office \\
\hline & \\
\hline . &
\end{tabular}

\section{EXTERNAL DISTRIBUTION}

64. H. A. Adler, Medical Division, Oak Ridge Associated Universities, Oak Ridge, TN 37830.

65. D. H. Alexander, Program Manager, International Technology Exchange, Program Support (EM-53), U.S. Department of Energy, Washington, DC 20585.

66. N. H. Cutshall, U.S. Department of Energy, RW-221, 1000 Independence Avenue, Washington, DC 20585.

67. J. J. Easton, Jr., Assistant Secretary for International Affairs and Energy Emergencies, IE-1, Department of Energy, Washington, DC 20545. 
68. J. F. Franklin, Bloedel Professor of Ecosystem Analysis, College of Forest Resources, University of Washington, Anderson Hall, Seattle, WA 98195.

69. D. J. Galas, Associate Director, Office of Health and Environmental Research, Office of Energy Research, ER-70, U.S. Department of Energy, Washington, DC 20545.

70. G. M. Hornberger, Professor, Department of Environmentl Sciences, University of Virginia, Charlottesville, VA 22903.

71. G. Y. Jordy, Director, Office of Program Analysis, Office of Energy Research, ER-30, G-226, U.S. Department of Energy, Washington, DC 20545.

72.

N. E. Korte, ORNL Grand Junction Office, 2597 B 3/4 Road, Grand Junction, CO 81502

73-79. R. O. Machanoff, Hazardous Waste Remedial Actions Program, U.S. Department of Energy, Tri-County Mall, Oliver Springs, TN 37840.

80. J. O. Moore, U.S. Department of Energy, Federal Building, Oak Kiuge, TN 37831.

81. R. H. Olsen, Vice President for Research, University of Michigan Medical Sciences Building II, \#5605, 1301 E. Catherine Street, Ann Arbor, MI 48109-0620.

82.

A. Patrinos, Acting Director, Environmental Sciences Division, Office of Health and Environmental Research, ER-74, U.S. Department of Energy, Washington DC 20585.

83. T. J. Phelps, Institute for Applied Microbiology, University of Tennessee, 10515 Research Drive, Suite 300, Knoxville, TN 37932-2567.

84. W. G. Phelps, Director, Safeguards and Security Division, DOE Field Office, P.O. Box 2001, Oak Ridge, TN 37831-8600.

85. J. A Reafsnyder, Deputy Assistant Manager, Energy Research and Development, DOE Field Office, P.O. Box 2008, Oak Ridge, TN 37831-6269.

86. F. J. Wobber, Environmental Sciences Division, Office of Health and Environmental Research, ER-74, U.S. Department of Energy, Washington, DC 20585.

87. R. W. Wood, Acting Associate Director, Office of Health and Environmental Research, Office of energy Research, ER-70, U.S. Department of Energy, Washington, DC 20545.

88. Office of Assistant Manager for Energy Research and Development, Oak Ridge Operations, P.O. Box 2001, U.S. Department of Energy, Oak Ridge, TN 37831-8600.

89-99. Office of Scientific and Technical Information, P.O. Box 62, Oak Ridge, TN 37831. 

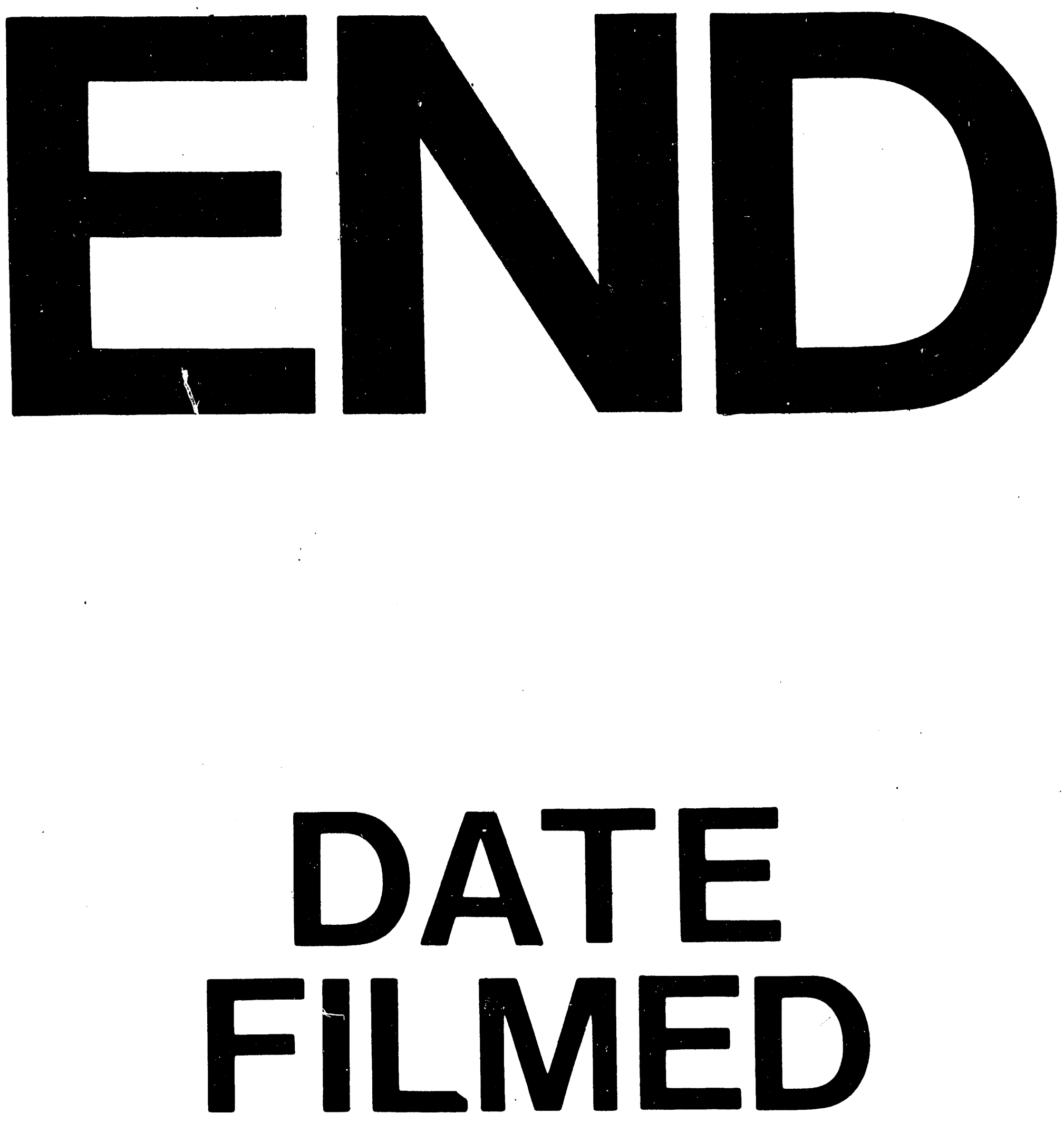

I

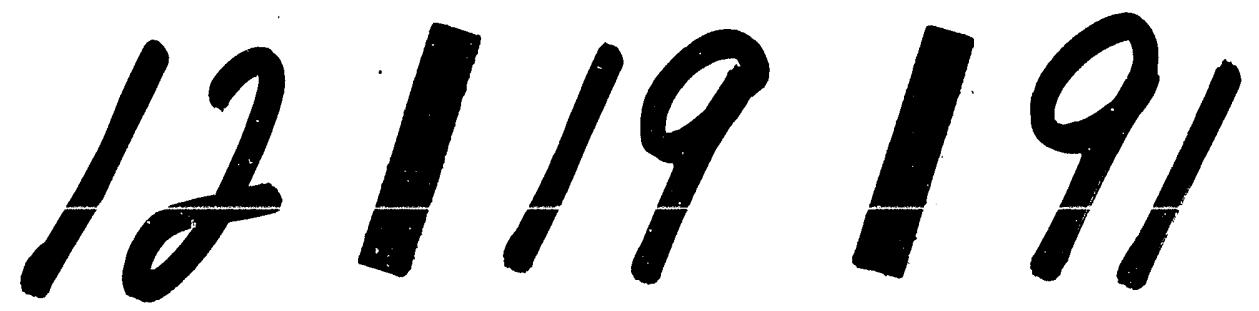


